UNIVERSIDADE DE SÃO PAULO

FACULDADE DE FILOSOFIA, LETRAS E CIÊNCIAS HUMANAS DEPARTAMENTO DE FILOSOFIA PROGRAMA DE PÓS-GRADUAÇÃO EM FILOSOFIA

\title{
ARTEFATOS E MODELOS DA MÚSICA NA ANTIGUIDADE OCIDENTAL
}

Cynthia Sampaio de Gusmão

n- USP: 2137048

Tese de doutorado

Área de concentração: Filosofia da Ciência e Epistemologia Orientador: Prof. Dr. Pablo Rubén Mariconda

\author{
SÃO PAULO \\ 2015 \\ VERSÃO CORRIGIDA
}

DE ACORDO,

Prof. Dr. Pablo Rubén Mariconda 


\section{Agradecimentos}

Ao CAPES/CNPq pela Bolsa de Pesquisa, que possibilitou a realização deste trabalho.

À família, em especial à minha mãe pelo apoio carinhoso, e à minha companheira Silvana, pela leitura cuidadosa e colaboração constante.

À paciência dos amigos e colegas.

E ao Professor Pablo Rúben Maricónda, pela abertura de novas perspectivas teóricas. 


\section{Resumo}

Este trabalho investiga o lugar da téchne no mundo antigo por meio dos instrumentos musicais, enquanto artefatos físicos e modelos matemáticos, geométricos e mecânicos. A escassez de informações sobre as técnicas de construção dos instrumentos leva a examinar outras atividades artesanais, especialmente aquelas ligadas à carpintaria e ao trabalho com metais. O exame da natureza do poder encantatório da música e sua relação com os instrumentos será realizado por meio da abordagem de figuras como as musas e os daimónes, e também da organização concebida pelos filósofos no período clássico. Apesar do lugar de inferioridade que importantes pensadores conferiram aos artesãos, evidências mostram que a téchne dos artífices marcou profundamente o pensamento grego. No que diz respeito à música, o papel do luthier foi fundamental na medida em que proporcionou o substrato material para desenvolvimentos na linguagem musical. Além dos artefatos, os modelos matemáticos, geométricos e mecânicos da música também nasceram nas oficinas. Ao serem dominados pelos músicos, tais rtefatos e modelos serão igualmente responsáveis por grandes transformações musicais.

Palavras-chave: lira, kithára, aulós, luthier, artesão, geometria, mecânica, sýrinx, hydráulis, hélicon, kânon, Aristóteles, Platão, Aristóxeno, Ptolomeu, Ctesibius, Arquitas, Hero de Alexandria. 


\begin{abstract}
This work investigates the Greek notion of téchne in the ancient world through its musical instruments, in the form of physical artifacts and mathematical, geometrical and mechanical models. Because of the lack of information about ancient lutherie, it examines other forms of craftsmanship, like carpentry and metallurgy. The inquire into the nature of the musical powers of music, and its relation to musical instruments, will be done by the examination of characters like muses and daimónes, and also of the organization models of the classical philosophers. Despite the inferior place that great philosophers give to the technicians, this study sustains that they had deeply influenced the Greek thought. Regarding music, it's possible to say that the luthier's role was fundamental because the material foundation conducted developments in the musical language. Besides the artifacts, the mathematical, geometrical and mechanical musical models were born in the workshops. Artifacts and models, mastered by the musicians, will be equally responsible for the musical developments.
\end{abstract}

Key-words: lire, kithára, aulós, luthier, artisan, geometry, mecanics, sýrinx, hydráulis, hélicon e kânon, Aristotle, Plato, Aristoxenus, Ptolemy, Ctesibius, Hero of Alexandria. 


\section{SUMÁRIO}

$\begin{array}{ll}\text { Apresentação } & 1\end{array}$

$\begin{array}{ll}\text { Introdução } & 4\end{array}$

PARTE I: A TÉCHNE MUSICAL DOS ANTIGOS 14

Capítulo 1 - ORGANOGRAFIA DA IDADE DO BRONZE 14

1.1 As ilhas cicládicas 14

$\begin{array}{ll}1.2 \text { A arte minoica da ilha de Creta } & 18\end{array}$

$\begin{array}{ll}1.3 \text { A cultura micênica } & 24\end{array}$

Capítulo 2 - AS RETÓRICAS DAS TECHNAI 35

2.1 As musas da renascença grega 35

2.2 A ambígua filotecnia dos helenos 41

2.3 As associações mágicas da téchne 56

2.4 Inovação no mito: a chélys-lyra 64

Capítulo 3 - ARTEFATOS E ARTÍFICES 68

3.1 A conjunção de técnicas na fabricação da kithára 68

3.2 Os artífices 102

$\begin{array}{ll}3.3 \text { Oráculos e concursos } & 117\end{array}$

3.4 O aulós e a sálpinx 122

$\begin{array}{ll}3.5 \text { Percussões e outros dispositivos } & 139\end{array}$

$\begin{array}{ll}3.6 \text { Artefatos-modelo: a harpa e a sýrinx } & 146\end{array}$

PARTE II: DA TÉCHNE À EPISTÉME 153

Capítulo 4 - A TEORIA MUSICAL GREGA 153

4.1 Modelos musicais 153

4.20 éthos musical na obra de Platão e Aristóteles 169

4.3 Instrumentos musicais na harmônica aristoxeniana 180

4.4 A convergência de matemática, acústica e mecânica 192 
Capítulo 5 - A HYDRÁULIS

5.1 O desenvolvimento da pneumática

5.2 A hydráulis no mundo romano

Capítulo 6 - O ATELIÊ MUSICAL DE CLAUDIO PTOLOMEU

6.1 A harmônica ptolomaica 228

6.2 A geometria musical de Claudio Ptolomeu 237

6.3 O céu musical de Ptolomeu 254

Capítulo 7 - A HERANÇA TÉCNICA DA ANTIGUIDADE 259

7.10 teclado 259

7.2 O braço do alaúde 263

$\begin{array}{ll}\text { CONCLUSÃO } & 270\end{array}$

$\begin{array}{ll}\text { Referências bibliográficas } & 276\end{array}$

Referências iconográficas $\quad 290$ 


\section{ARTEFATOS E MODELOS DA MÚSICA NA ANTIGUIDADE OCIDENTAL}

\section{Apresentação}

O presente estudo investiga a música na Antiguidade grega e romana do ponto de vista de seus instrumentos técnicos: lúdicos, de observação e de mensuração. A questão da técnica em si apresenta contradições agudas ao longo da história dos gregos. A admiração e o orgulho que eles demonstravam por seu domínio técnico, que proclamavam como uma distinção de sua cultura, foram ofuscados pela postura de autores como Platão, Xenofonte e Aristóteles, que advogaram uma posição inferior do trabalho técnico na sociedade grega. Contudo, mesmo nesses escritos, o território dos artesãos assume, em muitos momentos, e quase inevitavelmente, o lugar de destaque, reafirmando a complexidade dos sentidos da téchne ( no horizonte cultural dos antigos.

A música é uma arte privilegiada no que diz respeito ao campo técnico, uma vez que desde recuados tempos na história dependeu de instrumentos para a sua realização. Eles conduziram também as investigações acústicas desde a Antiguidade até a era moderna, fazendo o papel tanto de dispositivos de observação do fenômeno musical quanto de modelos de representação do som.

Assim, os instrumentos musicais podem ser, simultaneamente, artefatos e modelos. Até mesmo no âmbito da observação estrita pitagórica em uma simples corda, não é possível descartar a régua, ou cânone, após a medição, pois ela só se completa com a audição. Por conta disso, a música é um excelente campo de investigação das tensões entre as abordagens racionais e sensoriais da realidade, tendo construído um corpus filosófico razoável sobre o assunto.

No início do século XX, Paul Valéry, no texto "La conquête de la ubiquité", referiu-se às mudanças que a arte, em especial a música, 
começava a passar: "É de esperar que grandes novidades transformem toda a técnica das artes, agindo sobre a própria invenção, chegando mesmo a modificar de modo admirável a própria noção da arte" (1993, p. 3). ${ }^{1}$ O artigo de Valéry enfocava a reprodução do som e sua transmissão a longas distâncias, mas o seu diagnóstico, de que aspectos técnicos em si concorrem para a transformação da arte, no caso da música, aconteceu não apenas no século XX mas em toda a sua história, e isso se deve em larga escala aos instrumentos musicais.

Valéry encerra o artigo com uma exortação ao futuro, ao mesmo tempo em que relembra o passado de conexão entre a música e a ciência: "Tais são os primeiros frutos que nos propõe a nova intimidade da física com a música, cuja aliança imemorial tantos frutos já nos deu. E veremos muitos outros" (1993, p. 5). Mas, antes da relação com a física e, portanto, com a ciência, a música sempre esteve intimamente ligada à técnica, pois ganhou vida a partir de seus instrumentos e gestos técnicos. Os simples impulsos humanos de sacudir, raspar, bater, friccionar, tanger, beliscar, soprar, gritar, que se expandiram com os artefatos musicais, apresentam-se na esfera do espanto com a natureza - invisível - do som. Um longo processo de acumulação de conhecimentos sobre as qualidades vibratórias dos materiais conduziu a construção dessas miniaturas de engenharia, e do edifício da linguagem que as fez falar.

Assim como o surgimento de novos instrumentos impulsionou modificações nas práticas de performance e nas técnicas de composição, vários outros aparatos técnico-científicos foram criados para a observação e a representação da música. Ambos participarão ativamente do debate epistemológico que desponta na Antiguidade grega a respeito do tipo de relação que se estabelece entre análise teórica e prática real, ou entre razão e experiência. Com as

\footnotetext{
${ }^{1}$ Esse texto foi publicado no livro De la musique avant toute chose e um trecho dele, que inclui o apresentado acima, é a abertura de "A obra de arte na era de sua reprodutibilidade técnica", de Walter Benjamin, escrito em 1936.
} 
ferramentas técnicas, simultaneamente lúdicas, de observação e de mensuração, a música torna-se, ela mesma, um instrumento de abordagem e conhecimento do mundo.

Uma teoria da percepção sensorial foi delineada com a Estética do século XVIII, que rapidamente transformou-se em uma teoria do gosto, delimitando seu campo às obras de arte. Muitos debates tiveram então, como objeto, a primazia da atuação da sensação ou da razão, de cálculo ou da emoção, na criação e na recepção artística. Na música ocidental essa discussão surge na Antiguidade grega, com a controvérsia epistemológica entre pitagóricos e aristoxenianos, e autores como Claudio Ptolomeu, do século II d.C., refinaram o debate investigando ambas as perspectivas. Embora Ptolomeu não tenha avançado no sentido de colocar abertamente em cheque as questões do âmbito da ratio, suas propostas ampliaram de maneira significativa o campo da teoria da apreensão musical.

Mas afora tomar parte na disputa filosófica entre ratio e senso, a música, como em todas as culturas, esteva presente na vida cotidiana, nas narrativas míticas e na prática ritualística grega. Teofrasto de Ereso, na obra Sobre a inspiração, teria registrado que a música cura até mesmo doenças, dizendo que pessoas que sofriam de ciática eram liberadas permanentemente da dor se alguém tocasse o aulós sobre o local, na harmonia frígia (cf. Barker, 1989b, p. 281). Apesar de Barker nos lembrar que essa eficácia médica do aulós na narrativa de Teofrasto não significa que ele a subscrevesse (cf. 1989b, p. 281, n. 100), os instrumentos musicais guardaram essa aura do poder encantatório da arte dos tons e de depositários da milenar ciência da acústica. 


\section{Introdução}

Tão facilmente como uma pessoa conhecedora da phórminx e do canto tensiona uma corda em volta do kóllops novo, prendendo as duas pontas de tripas de ovelha bem torcidas, sem esforço armou Odisseu o grande arco. Puxando a corda com a mão direita, experimentou-a; ela cantou bonito como a voz de uma andorinha (Homero, Canto 21, vv. 406).

O herói Odisseu prepara-se para entrar em cena como experiente guerreiro, e Homero compara o tom produzido pelo beliscar da corda de seu arco ao canto de um pássaro; a poética do gesto enfatiza a sua eficácia. Mas quando Odisseu belisca o feixe de tripa sente também sua espessura e tensão. $O$ antigo modo de experimentar o arco não se limita à audição do tom da corda, mas à sua percepção tátil. A avaliação da tensão adequada, que se completa na vibração sonora, é o resultado da caminhada de gerações em busca do domínio da sua ferramenta, órganon (ôpyavov) uma extensão de seu corpo. O gesto de excelência técnica dos guerreiros da Idade do Bronze é similar ao daqueles que hoje preparam as cordas de seu violão.

Do mesmo modo que o âmbito sonoro e tátil é uma referência eficaz para a verificação de um arco ou de uma amarra de navio, ele o

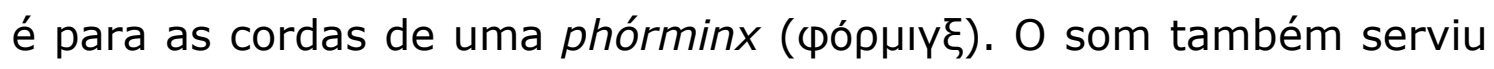
de guia para o artífice na verificação da densidade no cozimento de uma cerâmica, do volume do oco de uma tora de árvore ou da espessura das paredes de uma taquara. Os ouvidos humanos em forma de concha conhecem o espaço, seu tamanho e suas direções.

A identificação de pontos fixos em um espectro sonoro está dentre as qualidades sonoras percebidas, e a relação entre eles se desenrola no tempo. O aspecto vibratório, audível e tátil, presente na emissão do sopro em um tubo fechado, permite lançá-lo a longas distâncias. Quando se pode controlá-lo, abrindo e fechando orifícios ou 
tensionando e distensionando as cordas, são produzidos os tons musicais, que aos poucos configuram uma linguagem, para além da voz.

Para gerar os tons, e assim combiná-los ao ritmo, utiliza-se o que estiver à disposição: voz, junco, chifre, madeira, metal, tripas, peles e

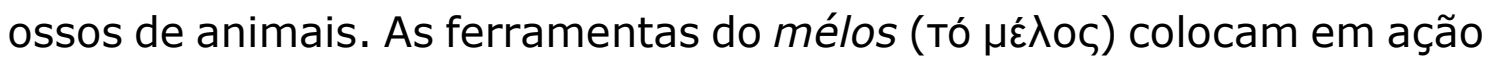
uma série de procedimentos que serão transmitidos ao longo da história. O objeto final, o instrumento musical, é uma pequena miniatura que reúne técnicas de construção, de avaliações empíricas e tomadas de decisões.

Assim como a perspectiva material sugere novas formas de produção da música, a amplificação dos gestos corporais cria antes impensadas atitudes do corpo. A reinvenção de gestos eficazes molda as técnicas de execução e performance, que por sua vez dão novas sugestões de como produzir o mélos. Quando uma cultura musical cria esse repertório é porque ela se sofisticou.

Nas epopeias homéricas existem referências às ferramentas e técnicas disponíveis na Grécia da Idade do Bronze. O próprio cavalo de Troia, se existiu, deve ter sido uma construção engenhosa, embora a narrativa não dê detalhes de como ele foi feito. Quase nada sobreviveu do trabalho em madeira que era feito na antiga Grécia, mas a partir de estudos referentes à construção dos móveis e dos navios é possível conhecer os meios técnicos disponíveis, como a utilização de encaixes tipo macho-fêmea e dispositivos de fixação com cordas, pregos de madeira e de metal, e cola, às vezes feita com tendões de animais, saindo do âmbito do carpinteiro para o do sapateiro ou dos que trabalhavam com curtume.

O trabalho com a madeira envolvia o entalhe, o tratamento com vapor, utilização de plainas e tornos. Odisseu conta o segredo da construção da sua cama, que ele mesmo fez monóxila a partir do tronco de uma oliveira. 
Há uma particularidade importante na construção desse bem fabricado leito que eu mesmo fiz, sozinho. Crescera dentro do pátio o tronco de uma oliveira de longas folhas. Forte e grosso, tinha a largura de uma coluna. Foi sempre em redor dele, até o fim, que construí minha alcova de compacta alvenaria; cobri-a com um bom teto e apliquei nela portas bem ajustadas e cerradas. Só então cortei a fronde da oliveira de longas folhas; desbastei o tronco desde a raiz, alisei-o bem em redor com o bronze, com maestria, igualando-o com um fio de prumo (ทंora $\theta \mu \eta)$, e assim formei um dos pés da cama, onde abri todos os furos com uma verruma. Ali montei a cama que poli e terminei com incrustações de ouro, prata e marfim; depois estiquei nele correias de couro de boi, de cor purpúrea brilhante (Odisseia, Canto 23, vv. 186204).

Esse tipo de técnica de construção feita dentro de uma única peça está presente em muitas culturas antigas, especialmente embarcações. A Odisseia é repleta de referências a técnicas de construção naval. Uma delas aparece no episódio em que Odisseu conta como ele e seus companheiros atacaram o olho do Cíclope. Eles constroem um mecanismo que é o mesmo usado para fazer os grandes orifícios nas pranchas de madeira dos navios. Eles fazem uma ponta em uma vara de oliveira, mas que não será utilizada pela força, pois é isso, a técnica, que diferencia o mundo dos cíclopes e o dos heróis gregos. O mecanismo é apresentado já em ação no olho único do monstro.

Eu, pesando de cima, a fazia girar [a vara de oliveira]; como um homem furando uma prancha de navio com uma grande broca, enquanto outros, por baixo, fazem-na girar numa correia, cujas pontas eles seguram, de modo que a broca volteia firme no mesmo lugar (Odissea, Canto 9, vv. 383-6). 
Há uma preocupação com a descrição detalhada da ferramenta de Odisseu e seus companheiros. Schuler diz que o princípio dessa ferramenta é o da pua de arco, na qual um único homem trabalha com as duas mãos, mas a ferramenta da Odisseia seria uma ferramenta derivada. Na pua de arco,

o artesão segura a pua verticalmente com uma mão e, com a outra, puxa para cima e para baixo o arco, com a corda do arco enrolada no cabo da pua, de modo que a broca gira nas duas direções alternadamente. Não existe nenhuma razão prática para não se construir uma pua muito maior, baseada no mesmo princípio, a fim de perfurar orifícios maiores ou mais profundos, exceto pelo fato de que o cabo deveria ser muito longo e desajeitado, daí a substituição do arco pelos dois assistentes. Alguns tornos antigos eram operados dessa forma, mas eu não conheço outra referência de outra pua desse tipo, mesmo em narrativas ou literatura de trabalho em madeira. $O$ autor [Homero] parece ter visto algo como essa pua em atividade, ou ouviu falar dela (Schuler, 2010, p. 1).

A ferramenta de furar é o trýpanon (Tò tpúnavov), mesmo termo utilizado pelos responsáveis em fazer os orifícios do aulós (ò aủhós), atividade em escala menor, mas que recebia uma atenção especial. Esse assunto específico mereceu uma obra, no século IV a.C., de

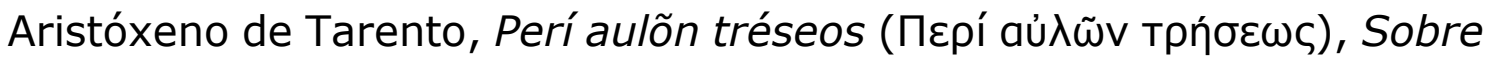
os orifícios do aulós, da qual nos restaram fragmentos.

O ambiente técnico perpassa constantemente a narrativa épica inicial do povo grego. O mesmo episódio do cíclope culmina com uma imagem advinda da prática metalúrgica. A vara de oliva, que eles haviam aquecido em alta temperatura, gira com o mecanismo do trýpanon e atinge o olho do cíclope Polifemo, assim como "quando um ferreiro mergulha na água fria da têmpera, que é donde vem a força do ferro, um machado grande ou uma acha de armas, e esta chia forte" (Odisseia, Canto 9, vv.391-3). 
Outra vertente da descrição homérica das técnicas metalúrgicas é o longo episódio, na llíada, da produção do escudo de Aquiles feito pelo deus Hefesto, que aciona seus foles para criá-lo em bronze, estanho, ouro e prata (cf. Canto 18, vv. 468-617). A narrativa suscita um misto de espanto, magia e temor. Mas na Odisseia, em especial a partir do canto nono, quando a epopeia passa a ser narrada pelo próprio Odisseu, o relato do conhecimento técnico é aquele que está ao alcance dos mortais. A admiração pela habilidade técnica significa o domínio das forças naturais e uma consequente demonstração de poder. A habilidade de Odisseu e seus companheiros representa a superioridade de seu povo, que está em franca oposição ao mundo não civilizado. A terra dos cíclopes é descrita como um lugar sem ágora, sem leis, em que as pessoas não cultivam, nem pastoreiam, "nem vivem construtores de barcos bem providos de bancos para Ihes irem buscar todas as utilidades, aportando a cidades de outros povos" (Odisseia, Canto 9, vv. 125-9).

As epopeias homéricas descrevem o trabalho em madeira e metal, duas artes que devem ser dominadas para a confecção dos instrumentos musicais. O tratamento poético, mas também documental, da técnica confirma uma postura grega que parece contradizer a noção de sua desvalorização pelos autores do período clássico. De qualquer modo, eles são bem posteriores ao momento em que a Ilíada e a Odisseia foram colocadas na forma da escrita, ou seja, na passagem do século VIII para o século VII a.C., após uma longa tradição oral. Como veremos no decorrer do estudo, a posição dos autores clássicos não revela todo o quadro do lugar da técnica na cultura grega.

A construção do mélos no espaço das ilhas e dos continentes cercados pelos mares Jônico e Egeu tem origem bem mais recuada que a dos helenos. Os instrumentos musicais encontrados em vestígios arqueológicos das ilhas cicládicas, de Creta e do mundo micênico, este 
último também representado em algumas passagens de Homero, são o testemunho de antecedentes sofisticados desse tipo de organopóia.

Em 1894, o musicólogo Theodore Reinach apresentou alguns fragmentos de música grega antiga com instrumentos ocidentais, provocando risos da plateia por sua bizarrice. Dois anos mais tarde, outro estudioso, François-Auguste Gevaert, procurou o luthier VictorCharles Mahillon, que havia construído réplicas de instrumentos orientais e africanos, para trabalhar na elaboração de alguns instrumentos gregos antigos. Apesar de ser um dos primeiros passos para um estudo concreto e mais adequado da música grega antiga, de acordo com Bélis, essa tentativa etnomusicológica apresentou "bases arqueológicas (...) ainda hesitantes" (2000, p. 203-4).

$\mathrm{O}$ belga Mahillon havia sido curador do museu de instrumentos do Conservatório de Bruxelas e criou, em 1880, para fins de catalogação, o sistema de classificação dos instrumentos musicais em aerófanos, cordófonos, idiófonos e membranófonos, que tornou-se posteriormente a base de sistemas consagrados como o de E.M. Hornbostel e Curt Sachs. A novidade de Mahillon foi ter acrescentado à classificação antiga tradicional em cordas, sopros e percussão, mais uma categoria, pois o seu sistema baseia-se no princípio de geração do som dos instrumentos. A classificação propunha as classes dos cordófonos, cuja produção do som é feita a partir de cordas, dos aerófanos, a partir de emissões de sopro, dos idiófonos, a partir do próprio corpo do instrumento, como as castanholas, e dos membranófonos, em que o som é gerado a partir de uma membrana, como pele de animal - por exemplo, os tambores.

A mais antiga divisão grega conhecida era feita em apenas duas categorias: instrumentos animados (a voz humana) e inanimados (sopros e cordas). A percussão não era considerada. No século II d.C., o gramático Pólux apresentou duas outras categorias: sopros e percussões, incluindo nessa última as cordas, puxadas ou percutidas. Essa percussão das cordas provavelmente referia-se à utilização do 
plectro ou a algum tipo de dulcimer com baquetas, como os que conhecemos atualmente em uso na Índia e no Oriente Médio.

De acordo com Wachsmann/Kartomi (2015, p. 4), a primeira classificação em sopros, cordas e percussão foi apresentada por Porfírio no século III d.C. Ela foi mantida por Boécio, na passagem do século $V$ para o VI, mas o autor, no entanto, tratou a percussão como irrelevante. Boécio preservou também a dicotomia grega animado/inanimado, ou ainda, natural/artificial, que marcará presença nas discussões renascentistas. No século XVII, Marin Mersenne, na seção de instrumentos musicais Da obra Harmonia Universal seguirá a classificação de Porfírio, que é a mais comum dos dias atuais: sopros, cordas e percussão.

$\mathrm{Na}$ China antiga, os instrumentos eram classificados de acordo com o material de que eram feitos: pedra, metal, madeira, bambu, couro ou seda. Nesse caso, instrumentos gregos como as krótala (Tà крóтa $\lambda a$ ) e a sálpinx ( fato de ambas serem feitas de bronze, enquanto que na distribuição ocidental corrente, eles estariam em campos diferentes: as krótala como percussão e a sálpinx como sopros. ${ }^{2}$

Uma organografia como a chinesa, feita a partir dos materiais de fabricação, nos parece bem mais produtiva para um estudo que investiga os processos técnicos de construção dos instrumentos, uma vez que seus princípios estão initimamente ligados ao material utilizado. Instrumentos como a sálpinx e as krótala poderiam ser produzidos no mesmo ateliê em que escudos de bronze fossem confeccionados e até mesmo sua criação pode ter surgido em um momento de ócio nas oficinas.

A descrição de um instrumento musical pressupõe a interação de vários ramos do conhecimento, que se unem no objeto estudado. A

\footnotetext{
${ }^{2}$ As krótala, espécies de castanholas podiam ser feitas de madeira com um disco de metal em seu interior, assim como a sálpinx, trompete grego antigo, podia também ser feito de osso com anéis de bronze.
} 
organografia da antiga Grécia inclui uma abordagem das evidências presentes nos textos poéticos e dramáticos, nas narrativas históricas e nos tratados musicais, nos vestígios arqueológicos, na iconografia presente em pinturas, relevos e esculturas e em um conhecimento básico das técnicas de execução musical, sem prescindir da imaginação. Além disso, as disciplinas de antropologia, história e geografia associam-se à pesquisa. Nossa atitude epistemológica implica olhar o artefato técnico como o produto de um longo processo de acumulação de conhecimento, como refere-se Lévi-Strauss ao falar de uma "ciência do concreto" (cf. Lévi-Strauss, 1962, p. 11-49), uma sedimentação milenar de sabedorias que abrange os campos da botânica, zoologia, geologia, química e física. Assim, seguimos Lloyd, quando diz:

Nós vemos como aspectos de um todo como as pessoas fazem para viver, qual a sua relação com as estruturas de autoridade, que laços unem as pessoas que fazem o mesmo trabalho, como eles comunicam o que compreendem, e que conceitos e pressupostos utilizam. Nós não pensamos em fatores sociais como capazes de determinar 0 pensamento, nem em ideias mudarem a sociedade. Essas causas não são externas. Pensadores respondem a, mas também influenciam, instituições e valores predominantes. Desse modo nós não falamos em investigação em contexto. Contexto não é um conjunto autônomo que pode ou não ser conectado à investigação. O trabalho técnico e suas circunstâncias são parte de uma única coisa, muito embora a especialização moderna dos estudos encoraje desmembrá-las (Lloyd, 2002, p. 3).

A cultura grega estabeleceu um alto padrão de conhecimento técnico e valorizou-o como símbolo de seus avanços civilizatórios. Para Burford, a valorização da técnica na cultura grega tem seu ponto alto na era arcaica quando obras de artesãos, como o escultor Euthykartides, do século VII a.C., começam a aparecer com registros 
de autoria. Na estátua que fez em homenagem ao Apolo de Délos, o artista escreveu: "Euthykartides nativo de Naxos me fez e me dedicou" (1972, p. 13). Mas esse auge técnico da era arcaica adveio de um longo processo anterior. Particularmente interessante é que esse conhecimento não se perde completamente nos ciclos históricos em que sobrevêm as guerras e as catástrofes, parecendo dormir, para serem recuperados adiante. Na história da técnica musical grega é possível perceber uma continuidade entre o período cicládico e o arcaico, que passa pela chamada Idade do Ferro, da qual temos pouquíssimas notícias, inclusive com cataclismas como a erupção do vulcão na ilha hoje conhecida como de Santorini que afetou todo o conjunto egeano. Finley confirma que "algumas habilidades específicas em algumas técnicas foram perdidas como resultado da queda dos palácios micênicos gregos, por volta de 1150 a.C., mas não em todas elas" (1990, p. 69).

A trajetória dos instrumentos musicais passa pelos caminhos que geram seus princípios de construção. Alguns deles se mantêm e outros se modificam. A divisão histórica em período pré-helênico e helênico ou em idades do bronze, do ferro, arcaica, clássica e helenística não faz sentido do ponto de vista da técnica dos instrumentos musicais, se esse olhar investigativo não recair sobre a linhagem dos princípios de construção. Se há uma interrupção na transmissão do conhecimento técnico, via de regra, ele é retomado em algum momento adiante.

Quando olhamos para as referências nas epopeias homéricas pelas quais iniciamos o nosso estudo, isso fica ainda mais contundente. Várias camadas de tempo superpostas estão presentes nessas narrativas: a dos palácios micênicos na Idade do Bronze, a da Idade Obscura, ou do Ferro, e a da passagem do século IX para o VIII a.C., início do período arcaico, quando os poemas foram escritos. Tanto a Ilíada quanto a Odisseia retratam sistemas de organização da idade obscura, mas os palácios e tesouros que aperecem no poema são representantes de uma idade mais antiga, a micênica. Elementos da 
própria era arcaica também surgem mesclados à narrativa do passado glorioso dos helenos, os chamados aqueus, argivos e danaãs ou danaos.

O que é conhecido como cultura grega antiga tem seu início no chamado período arcaico, em torno da segunda metade do século IX a.C., com a concepção de povo helênico. Em geral, os musicólogos consideram a música grega apenas a partir desse momento, pois não se poderia falar de algo propriamente grego nos períodos anteriores à helenização desse espaço geográfico, numa época em que, como diz Finley, "a comunidade tinha uma existência indistinta enquanto organismo político" (1990, p. 99). Mas do ponto de vista do presente estudo, ou seja, da técnica musical - que compreende a construção de seus instrumentos e os gestos de performance para a configuração de sua linguagem - a investigação se inicia antes do chamado tempo histórico dos helenos.

\begin{tabular}{|c|c|c|c|c|c|c|}
\hline & IDADE DO BRONZE & IDADE DO FERRO & ERA ARCAICA & PERÍODO CLÁSSICO & \multicolumn{2}{|c|}{ PERÍODO HELENÍSTICO } \\
\hline cicládico & & & & & grego & romano \\
\hline \multicolumn{7}{|l|}{ minoico } \\
\hline & micênico & & & & & \\
\hline
\end{tabular}




\section{PARTE I: A TÉCHNE MUSICAL DOS ANTIGOS}

Há sempre um momento, não estando ainda a ciência de certos fatos reduzida a conceitos, não estando esses fatos sequer agrupados organicamente, em que se planta sobre essa massa de fatos o marco da ignorância: "Diversos". É aí que devemos penetrar. Temos certeza de que é aí que há verdades a descobrir; primeiro porque se sabe que não se sabe, e porque se tem a noção viva da quantidade de fatos.

Marcel Mauss, Noção de técnica do corpo

\section{Capítulo 1 - ORGANOGRAFIA DA IDADE DO BRONZE}

\subsection{As ilhas cicládicas}

Nos períodos anteriores à era arcaica grega, floresceram as civilizações das ilhas cicládicas no mar Egeu, minoica na ilha de Creta e micênica na Grécia continental, no transcorrer da chamada idade do bronze. Evidências materiais de instrumentos musicais remontam ao

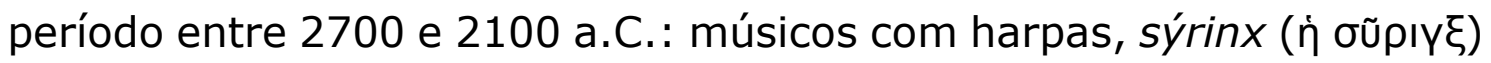
e aulós (ò aủ入ós) estão representados nas pequenas estatuetas em mármore encontradas em túmulos das ilhas cicládicas, mostrando que ali já estavam definidas três técnicas de produção do som: sopros em tubos organizados em conjuntos (Fig.1) ou em tubos com orifícios (Fig. 2) e cordas beliscadas com os dedos (Fig. 3). A feitura dessas estatuetas indica que essa sociedade dominava princípios da linguagem musical como melodia e ritmo. 


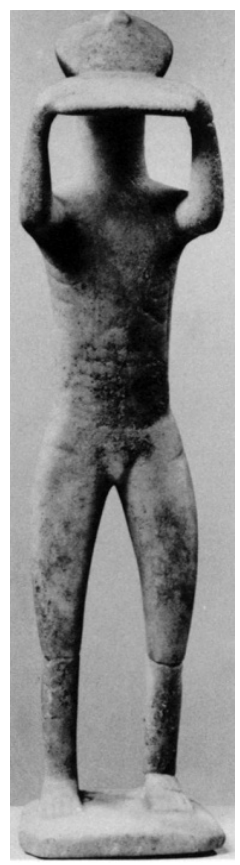

Fig. 1: Estatueta das ilhas cicládicas. Músico tocando a sýrinx, c. 27002100 a.C.

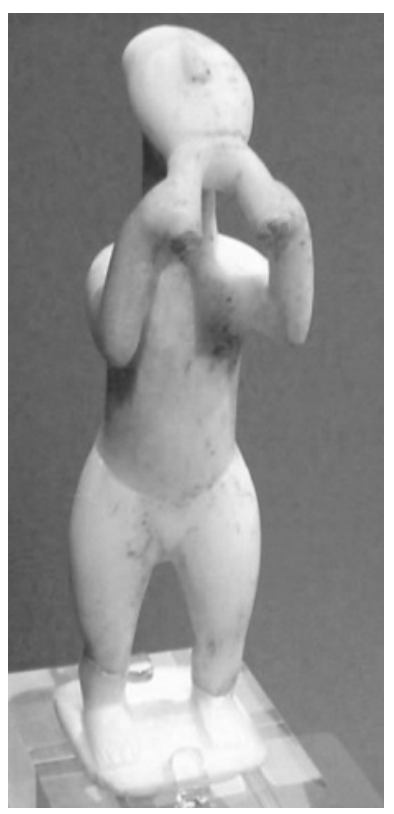

Fig. 2: Estatueta das ilhas cicládicas. Músico tocando o aulós, c. 2700-2100 a.C.

Na sýrinx, a música é produzida pela diferença de tamanho com que foram cortados os juncos, possibilitando a produção de distintos tons, tal como a zampoña andina. O instrumento na estatueta está levantado, perpendicular ao músico, mas não podemos inferir que essa fosse de fato a forma de tocá-lo, pois ele necessita de alguma angulação para baixo a fim de que o som seja produzido, tal como quando sopramos em uma garrafa. Mas esse poderia ser o momento final da performance, quando o músico em geral levanta o instrumento.

O aulós representado na estatueta é duplo e seus tons são produzidos pelas distâncias entre os orifícios abertos em seus tubos. Teriam a mesma afinação que a sýrinx? 


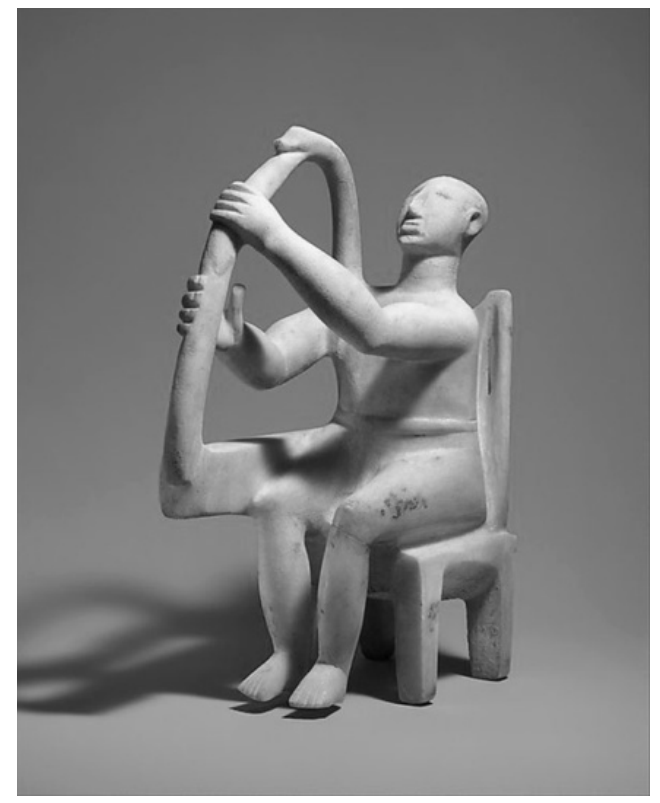

Fig. 3: Estatueta das ilhas cicládicas. Músico tocando harpa, c. 2700-2100 a.C.

Na harpa, a posição do músico é sentada. O instrumento apoiado dessa maneira permite que ele utilize as duas mãos para tanger ou dedilhar as cordas. O instrumento é de caixilho, ou seja, possui um suporte frontal ligando o seu pescoço à caixa de ressonância.

O princípio de construção das harpas é muito próximo do arco de caça e pesca, artefato que se espalhou pelo mundo após o último período glacial. ${ }^{3}$ A função do arco é lançar projéteis, como uma flecha, a longa distância. Uma única corda liga as duas pontas das extremidades do arco e a tensão da corda influi na distância e no vigor da emissão de seus projéteis.

Se o arco de caça e pesca pode ser visto como uma extensão do gesto de lançar algo à distância, a harpa não é um prolongamento de nenhum movimento, é uma tecnologia que produz efeitos e gestos inteiramente novos. Quando aumentamos o número das cordas de um arco, deslocando-as para o interior do instrumento, transferimos a função de emitir projéteis, que tinha o arco, para a de emissão de sons de alturas variadas, alterando assim a sua função inicial.

\footnotetext{
${ }^{3}$ Os mais antigos vestígios são do conjunto de arcos feitos de elmo encontrados na Dinamarca, sendo datadas como do período mesolítico, cerca de 9000 a.C. São os chamados arcos de Holmegaard. Cf. http://www.archerie-primitive.com/articles/arcs-holmegaard.htm
} 
Como vimos na Odisseia, o teste para verificar a tensão por meio do som é bastante antigo. O tato percebe a espessura da corda, elemento fundamental na produção desse tom. O aspecto tátil determina, até hoje, a diferença de fabricação das cordas de um piano, que não serão beliscadas pelos dedos, daquelas de um violão (cf. Campbell, 2009, p. 281-2). O comprimento de vibração da corda, tanto no caso do arco de caça, quanto das harpas, significa a corda em toda a sua extensão.

As harpas em geral possuem os seguintes componentes estruturais: a caixa de ressonância, a moldura e as cordas graduadas. As antigas harpas egípcias tinham a sua morfologia mais próxima do arco de caça, pois a sua moldura curvada tinha um lado aberto; nas harpas mesopotâmicas, a moldura era construída na forma de um triângulo, também com um lado aberto. As harpas cicládicas eram fechadas numa estrutura em três lados. Por conta desse formato,

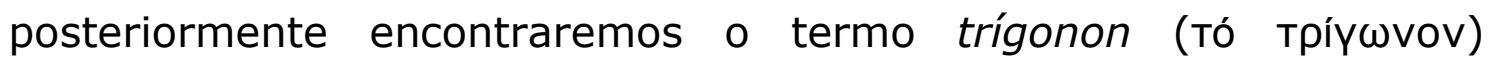
referindo-se às harpas gregas. De acordo com Maas e Snyder, o suporte frontal é o elemento morfológico que torna as harpas produzidas nas ilhas cicládicas gregas diferentes das harpas das civilizações egípcia e mesopotâmia, que eram abertas na lateral (cf. 1989, p.1).

A busca pela produção mais eficiente de sons levou os artesãos a estabelecerem posições específicas para a fixação das cordas graduadas, de modo que elas tivessem os comprimentos desejados. Para tal, percebeu-se que não era necessário, e nem mesmo desejável, que a corda mais longa estivesse exatamente na ponta, como no arco de caça e pesca. Desse modo, podemos dizer que, nessa harpa cicládica, a corda da ponta do arco de caça foi deslocada e em seu lugar foi instalado um suporte frontal, emoldurando as cordas e fortalecendo toda a estrutura do instrumento. É um design notável: simples, eficiente e belo. Na parte superior, no ponto de encontro do suporte frontal com o pescoço da harpa, uma protuberância sugere 
uma ornamentação como um bico de pássaro, um pescoço de cisne ou uma boca de serpente (Fig. 4).

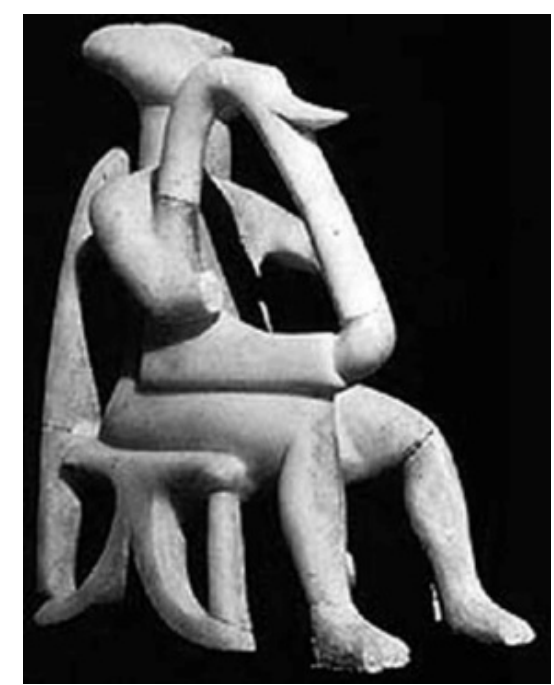

Fig. 4: Estatueta das ilhas cicládicas. Músico tocando harpa, c. 2700-2100 a.C.

\subsection{A arte minoica da ilha de Creta}

Nos afrescos e cerâmicas da cultura minoica da ilha de Creta, não há traço das harpas cicládicas. O instrumento de cordas que aparece possui dois dos seus traços estruturais: caixa de ressonância e moldura contínua, mas as cordas têm comprimentos iguais, em vez de graduados, ou seja, com princípios diferentes para a obtenção dos tons. Esse novo instrumento ficou conhecido como lira minoica.

As cordas já não ficam dispostas ao longo do instrumento, mas estão posicionadas no âmbito de abertura da mão do músico, na medida em que o instrumento está sendo tocado com o executante de pé, o que impossibilita a mobilidade do braço e antebraço a partir do ombro. A representação mais exuberante dessa lira está nos afrescos da Hagia Tríada no palácio de Cnossos, que retratam uma cerimônia fúnebre (Fig. 5). 


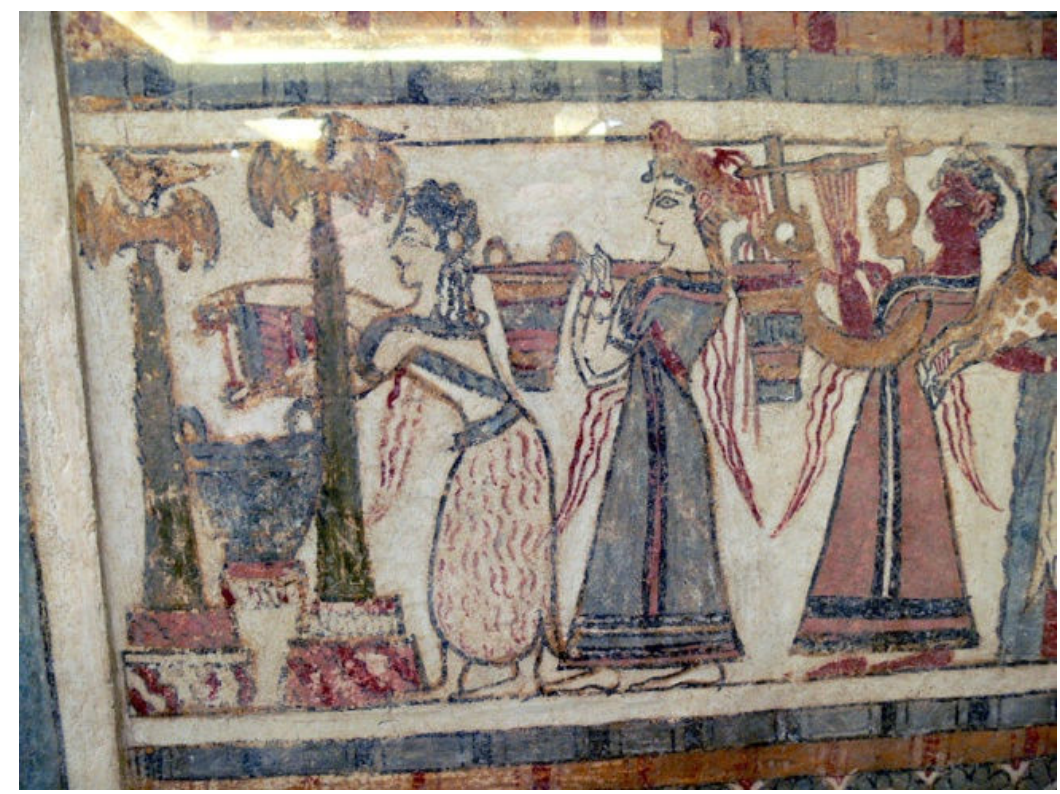

Fig. 5: Lira minoica: sarcófago de Hagia Tríada em Cnossos, Creta, c. 1550 a.C. À direita, músico com lira.

Alguns estudiosos sustentam que a lira minoica seja um desenvolvimento da harpa cicládica triangular porque ambas possuem ornamentos representando animais (cf. Creese, 1997, p. 27-30). É um argumento fraco, na medida em que pode ter havido uma transmissão da conexão mitológica ou ritualística da prática musical, sem que isso implique necessariamente que tenha havido uma mesma linhagem na construção de instrumentos. Ornamentações em instrumentos demonstram apenas que os artesãos, além de dominarem princípios de acústica, valorizam o poder encantatório da música, fazendo com que o instrumento ultrapasse a função de produzir sons, tendo um componente anímico adicional.

Outra vertente defende que a harpa cicládica e a lira minoica são instrumentos diferentes por apresentarem formas de execução distintas. Nos instrumentos minoicos, em vez de as cordas serem diretamente tangidas pelos dedos, aparece o plectro, um acessório que podia ser talhado em metal, osso ou marfim, com o qual eram tangidas as cordas, o que propiciava um som mais claro e de maior penetração.

Para Creese, o fato de as harpas cicládicas serem representadas com o músico na posição sentada e as liras "com o músico de pé (talvez 
andando?) conta como uma diferença importante" (1997, p. 24). Novamente, esse argumento não é suficiente; como exemplo podemos pensar em instrumentos como o violino e a flauta, tal como os conhecemos, que podem ser tocados tanto na posição sentada quanto na de pé, e isso não significa que tenham os mesmos princípios de construção e execução.

Outra discussão que surge em relação à lira minoica é em relação a sua origem geográfica. Creese sustenta que a lira não tem origem na região do mar Egeu, mas na Mesopotâmia (1997, p. 35). Esse argumento ganha peso com a representação de uma lira suméria no mural de Beni-Hassan, ca. 1900 a.C., ou seja, anterior às representações da lira minoica, e que foi estudada por Duschesnes \& Guillemin (cf. 1935. pp. 117-124). Nesse mural, um músico empunha uma lira, de pé, ou seja, em posição idêntica às representações minoanas. Além disso, essa seria a representação mais antiga "em que vemos um músico utilizando um plectro" (Creese, 1997, p. 37).

Mas o instrumento sumério possui braços assimétricos (cf, Duschesnes \& Guillemin, 1935, p. 117-124) e o instrumento cretense é representado, em geral, com os braços paralelamente simétricos. Maas e Snyder dizem que a característica que distingue as liras minoicas das egípcias e mesopotâmicas são os braços simétricos (1989, p.9). A abordagem dos princípios de execução e construção não converge e, assim, novamente voltamos à estaca zero na questão da origem da lira minoica.

Essa discussão está aqui colocada apenas para enfatizar que a questão da origem geográfica do instrumento, por mais curiosa que possa ser, não é relevante para o estudo que ora apresentamos. Para tal, é mais importante e adequado perceber o longo processo de aquisição de conhecimentos que são transmitidos de uma cultura a outra. Nunca se poderá saber se um viajante solitário conheceu um instrumento e o trouxe para sua terra. A história tanto das harpas quanto das liras, ou de qualquer outro instrumento, passa pelos 
caminhos que geraram seus princípios de construção e suas necessidades de performance.

Harpas e liras necessitam tensionar as cordas. Se for preciso tocar em pé, ou andando, outras características têm de ser desenvolvidas, pois o instrumento perde o seu apoio nas pernas do músico, e assim as mãos têm seu âmbito de movimento reduzido. Alguns princípios, como a caixa de ressonância e a moldura, se mantêm, outros se modificam.

Mais relevante para o nosso estudo é saber que o termo para o plectro, pléktron (то̀ $п \lambda \tilde{n}$ ктроv), em grego significa também ponta de lança. Isso nos remete às oficinas de produção de armas, como capacetes e escudos, contexto em que é possível que tenham se desenvolvido ideias e artefatos para outros fins, como a música. 0 suporte em couro, que sustentava o escudo sobre a cabeça do soldado

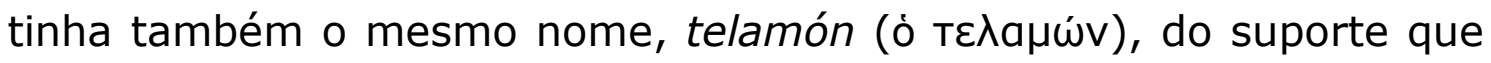
segurava as liras.

Não é possível conhecer o número de cordas nem o tamanho exato da lira minoana. Embora em alguns casos salte à vista o grau de detalhamento das representações, temos de levar em conta que os artistas nem sempre retratavam com fidelidade absoluta os instrumentos. A caixa de ressonância e os braços da lira minoica cretense provavelmente eram manufaturados de um material único, ou seja, de um mesmo tipo ou um único pedaço de madeira. Na lira do afresco de Hagia Tríada é possível observar claramente o ornamento em forma de serpente ou de pescoço de cisne nos dois anéis laterais, bem como o travessão superior da lira, que tinha a função de segurar e retesar as cordas. Aparece ainda o dispositivo técnico do qual sabemos o nome que tinha no tempo de Odisseu: o kóllops (ó kó $\lambda \lambda \circ \Psi$ ), um pedaço de couro enrolado no travessão para aumentar a fricção das cordas no local. O kóllops era confeccionado de couro curtido, o que fazia com que o atrito mantivesse as cordas esticadas e, portanto, afinadas, por mais tempo. Isso era importante pois uma circunstância 
de performance, tal como a cerimônia retratada no afresco, podia ser de longa duração e o músico deveria garantir a sua atuação assim como ter soluções para a manutenção da afinação. Outro recurso que aparece representado é um suporte acomodado por detrás do pescoço do intérprete, permitindo que os músicos tocassem de pé e mesmo em movimento.

Na pintura, o artista mostra o músico em ação, utilizando os dispositivos técnicos. O plectro está na sua mão direita e o suporte do braço esquerdo, de pano ou couro, passa por trás do seu pescoço, liberando a mão esquerda para abafar ou beliscar as cordas ou, quem sabe, fazer um bordão.

Em outro afresco do sarcófago de Hagia Tríada em Cnossos, está um auleta cuja cabeça e parte superior do seu tronco estão ligeiramente inclinados para trás, indicando a aplicação de força suplementar para produzir os sons nos dois tubos de madeira (Fig. 6).

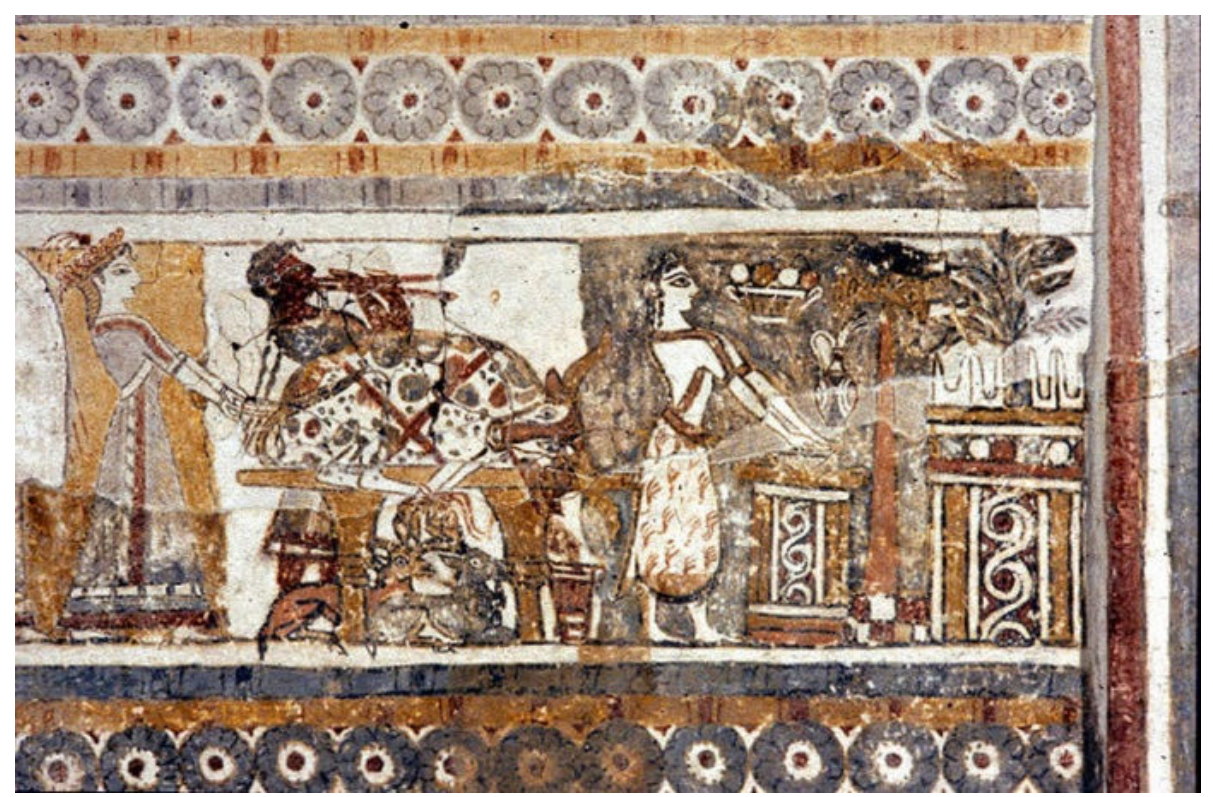

Fig. 6: Sarcófago de Hagia Tríada em Cnossos, Creta, c. 1550 a.C., com músico tocando aulós com campânula em um dos tubos.

Apesar de nada revelar a iconografia sobre o modo de produção do som, o gesto e as evidências posteriores nos levam a supor que a forma de fazer vibrar os dois tubos já era por meio de palhetas, 


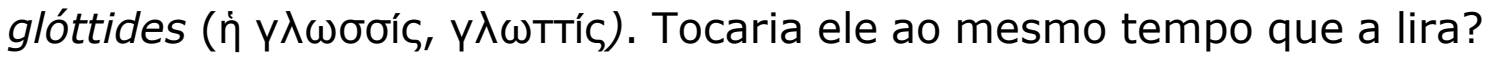
E, em caso afirmativo, que tipo de combinação musical produzir-se-ia?

Na extremidade do tubo esquerdo do aulós há uma campânula apontada para cima, revelando que se trata de um tipo específico de aulós, que será conhecido posteriormente como frígio. Esse pavilhão era feito de chifre, kéras, (Tó képac), e por isso o instrumento também foi chamado de keraúlos e ainda élymos kerástes. A kéras era encaixada no tubo esquerdo do instrumento, fazendo com que ele produzisse um som mais grave. Como diz Bélis, a associação de uma seção cilíndrica a uma seção cônica produziria um timbre mais rouco, qualidade conhecida dos construtores de instrumentos (cf. Bélis, 1986b, p. 25).

Teofrasto relata que o tubo do aulós em geral era feito de buxo (buxus sempervirens), madeira muito dura, que até hoje é apreciada para a fabricação das ponteiras das gaitas de fole, ou loto (celtis australis) (cf. 1916, p. 304-6). As plantas mais resistentes facilitam o trabalho no torno. A utilização de tornos de vara em desenhos egípcios é atestada, ao menos desde 1300 a.C., assim como em outras regiões do mundo antigo.

O aulós foi assim chamado de frígio pelos gregos de épocas posteriores, que tinham o hábito de distinguir muito claramente os instrumentos nativos dos estrangeiros. É viável supor que Creta tenha sido um ponto intermediário entre a Frígia e o continente grego. Os frígios viviam no centro-oeste da Ásia Menor. O apogeu da sua cultura ocorreu no século VIII a.C., quando, de acordo com Finley, ela era "mais avançada que a dos gregos em termos materiais e tecnológicos" (1990, p. 86). Após essa representação minoica, o aulós frígio só vai aparecer na Grécia do século VI a.C., ou seja, já no período arcaico. 


\subsection{A cultura micênica}

A última fase da idade do bronze é representada pela cultura micênica que floresceu no continente grego. De acordo com vestígios arqueológicos, ela possuía um instrumento muito parecido com a lira minoica. Na pintura do palácio de Pylos, no Peloponeso, há uma imagem de um músico com uma lira, em posição de performance; não há nessa representação dispositivos como o plectro ou o apoio para o braço. Parece que há uma ênfase maior do artista numa composição geral do afresco, prescindindo do detalhamento. Contudo, a ornamentação é muito precisa, com dois pescoços de cisnes nas laterais, perfeitamente simétricos (Fig. 7).

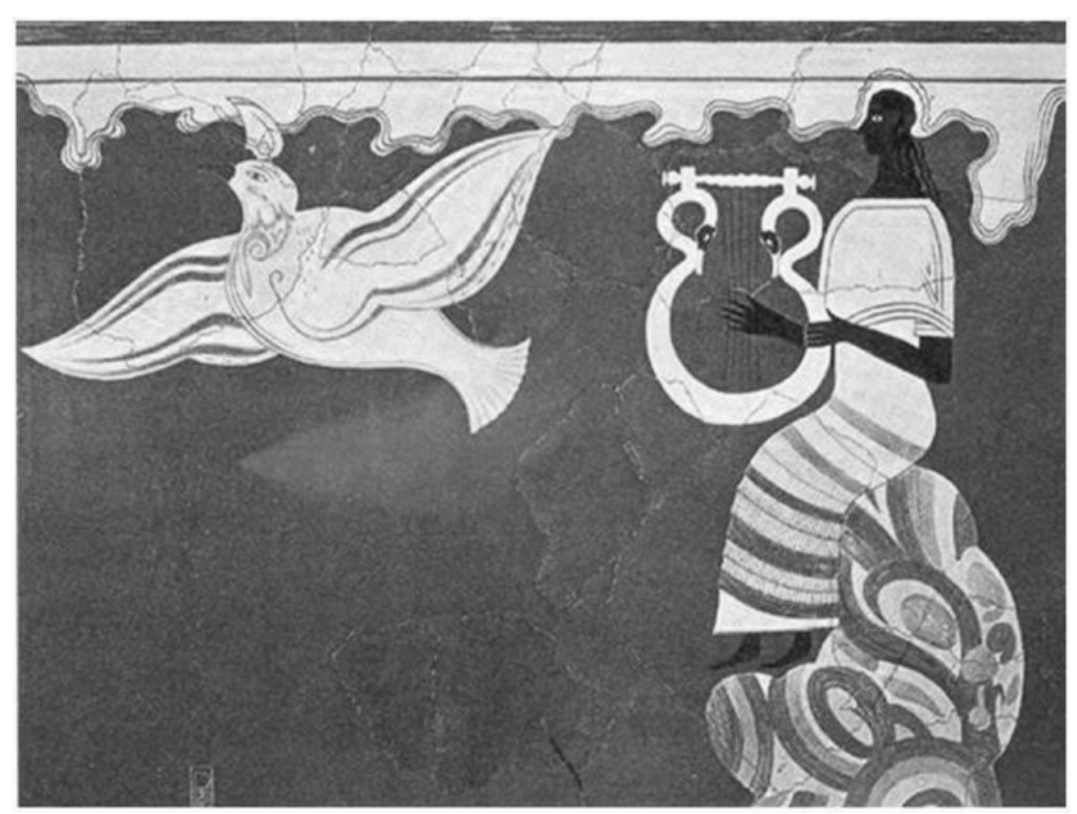

Fig. 7: Lira micênica no palácio de Pylos, c. 1400-1100 a.C.

Os vasos e cerâmicas do período micênico demonstram uma riqueza condizente com os tesouros descritos por Homero. Por exemplo, a lira de marfim encontrada numa construção em Menidi, ao norte de Atenas, revela um trabalho elaborado de ornamentação. Junto com ela foram encontrados plectros com cabo, ou punho, como pequenas colheres. $\mathrm{O}$ formato do dispositivo dava estabilidade na sua 
empunhadura e deve ter propiciado variações na sonoridade, de modo que a técnica de execução possivelmente tenha se aprimorado (Fig. 8).

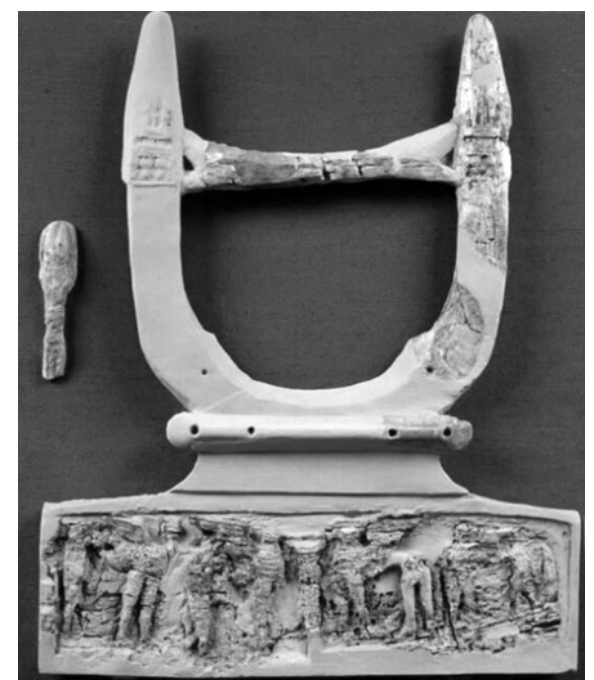

Fig.8: Lira de marfim e plectro, encontrados em Menidi, c.1400-1100 a.C., restaurados.

Em outros fragmentos de vasos micênicos é possível ver liras com indicações do plectro e do suporte para o braço, como o desse vaso encontrado em Náuplia no Peloponeso (Fig.9).

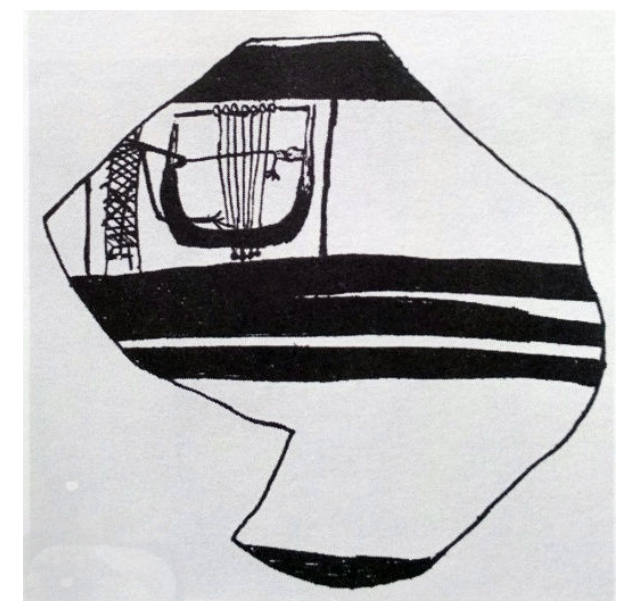

Fig. 9: Fragmento encontrado em Náuplia com imagem de instrumento de cordas, com plectro preso ao braço, c. 1400-1100 a.C.

Mas além do palácio de Pylos e dos vestígios arqueológicos, podemos conhecer os instrumentos do período micênico por meio de referências nas epopeias homéricas. Ali, eles são chamados por seus 
nomes e conhecemos também os termos técnicos referentes às suas partes.

Não importa se esses instrumentos da idade do bronze não são considerados propriamente gregos pelos musicólogos, pois são de fato pré-helênicos. Contudo, do ponto de vista da história da técnica dos instrumentos da Antiguidade, eles pertencem à linhagem das suas liras, harpas e auloi. É importante relembrar que, como é de se esperar, não há um padrão na construção dos instrumentos; o que existe é a resposta da eficácia e a consequente transmissão desse conhecimento.

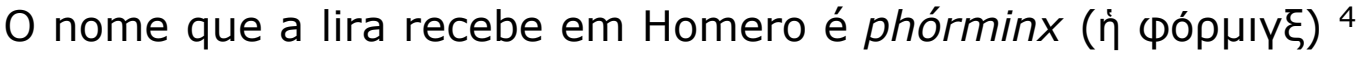
e o ato de tocá-la é kitharízein (Kı̈apí̧zıv), sem que, no entanto, o termo kithára (ì kıӨápa), que no período arcaico será um instrumento em si, apareça. A phórminx era um instrumento de cordas, com uma base arredondada, parecida com a lira minoica. Os braços subiam verticalmente feitos provavelmente da mesma peça de madeira que sua base com uma pequena caixa de ressonância (Fig. 10).

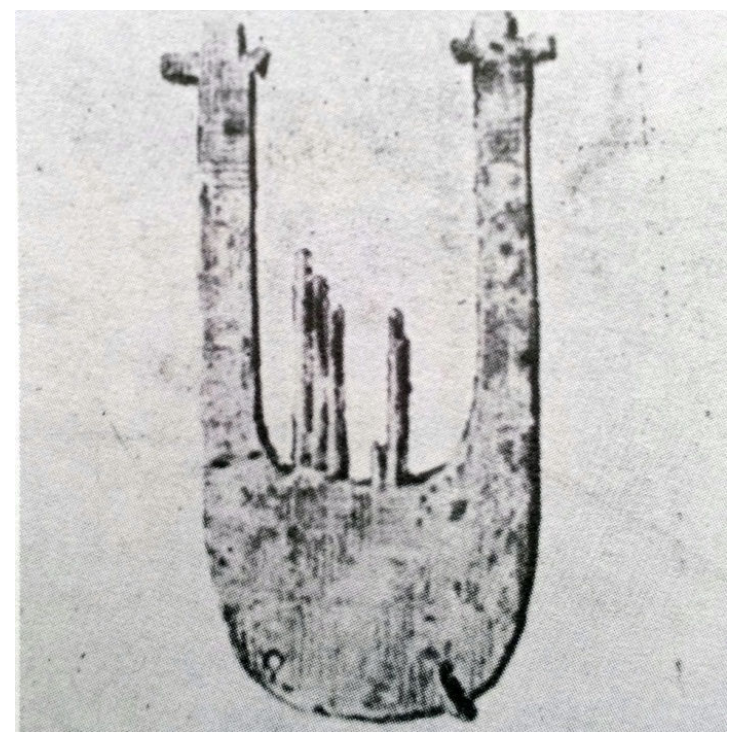

Fig.10: Pequeno bronze, talvez uma oferenda votiva, encontrado em Amyklaion, Esparta, c. 1400-1100 a.C. O instrumento é composto de uma caixa de ressonância grande e braços compridos. Embaixo, à direita, vemos um gancho para prender o plectro.

\footnotetext{
${ }^{4}$ Vários instrumentos tinham nomes terminados em -inx. Além dos citados existia ainda a phótinx, ou aulos líbio, uma espécie de pífaro.
} 
A Odisseia, no canto que abre este estudo, nos faz saber que as cordas da phórminx eram feitas de tripa de carneiro bem torcidas. $\mathrm{Na}$ cena, conhecemos também o modo de prender as cordas no kóllops. Maas e Snyder apontam que alguns autores traduzem imprecisamente o termo kóllops por cravelha: entretanto, diferentemente da cravelha, que gira para puxar a corda, o kóllops seria apenas um artefato de couro no qual as cordas eram enroladas de modo a manter a sua afinação. O nome adviria do fato de ser usualmente fabricada a partir dos músculos da nuca de carneiros e ovelhas. As autoras citam o bizantino Eustáquio que, comentando a respeito desse termo, diz que ele deriva da kólla (cola) que os antigos produziam fervendo essas mesmas fibras musculares (Maas e Snyder, 1989, p. 6).

Na Ilíada, outra parte da phórminx é nomeada: o zygón (Tó

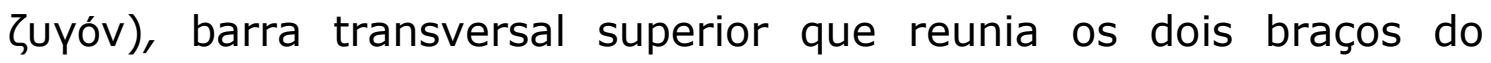
instrumento. No canto nove, Nestor e Odisseu vão até Aquiles e o encontram cantando e tocando uma lira na qual chama a atenção seu zygón de prata. Homero revela que o artefato é um despojo de guerra.

Aí enlevado o encontraram [Aquiles] tangendo uma clara phórminx De zygón de prata, toda ela de bela feitura, Que ele do espólio do burgo de Eecião para si separara (Canto 9, vv. 185-8).

Para Maas e Snyder, essa cena de Aquiles pode ter influenciado a paideia musical do período clássico.

A presença da phórminx nas mãos de um grande herói como Aquiles pode ter contado, em parte - tal como um endosso bíblico - para a persistência da lira como elemento essencial na educação da aristocracia ateniense de tempos posteriores (1989, p.6). 
Essa observação das autoras é curiosa, pois pode corroborar a ideia de que os aristocratas do período clássico se espelhavam nos deuses e apreciavam manusear hábil e facilmente um artefato musical, do qual eles não tinham noção de como havia sido feito.

A linguagem formular homérica atribui epítetos aos deuses, aos heróis e a alguns objetos (cf. Parry, 1971). A phórminx recebe o epíteto ligýs ( $\lambda$ ıүús), de som claro, agudo, penetrante, em uma referência a seu timbre, devido à utilização do plectro, e também glaphýren

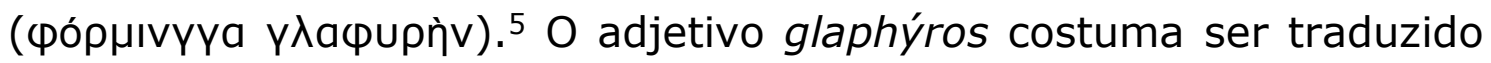
por "redonda" e "côncava", contudo, pensamos que as traduções "polida" ou "escavada" poderiam indicar, respectivamente, um aspecto estético e outro morfológico do instrumento. Para Maas e Snyder,

glaphuros pode significar "curvado ou "arqueado" além de "oco". Homero sempre o utiliza em relação a cavernas (ou seja, oco, no sentido estrito do termo) mas ele também o aplica para um porto (Odisseia, Canto 12 v. 305), uma margem marítima que se curva no sentido de formar uma área protegida, e para navios, e ambos são "ocos" e curvos" (1989, p. 7).

No canto dezoito da Ilíada, como já mencionado, Tétis pede a Hefesto que confeccione um novo escudo para Aquiles e o ferreiro mítico grava no artefato de bronze, estanho, ouro e prata, cenas em movimento que ocorrem simultaneamente em várias partes do mundo. Para enfatizar esses acontecimentos simultâneos, Homero apresenta circunstâncias de performance de dança e música. Os versos 490 a 495 descrevem um casamento em que vários auloi e phormíngues tocam juntos. Entre os versos 523 e 529 soam as syríngues dos pastores, que não sabem ainda que em seguida serão saqueados pelos heróis. Nos versos 565 a 573, uma clara phórminx é tocada (kitharíze) acompanhando o canto de fertilidade de Linos.

\footnotetext{
${ }^{5}$ Odisseia, Canto 18, v. 256 e Canto 20, v. 340.
} 
Outro instrumento mencionado por Homero só aparecerá em representações a partir do século VI a.C.: a sálpinx, um tubo cilíndrico, comprido, podendo ser feita de metal, bronze ou ferro, ou de osso, com anéis de metal. O tubo em geral terminava em uma campânula com uma boquilha de osso (Fig. 11). É possível encontrar ainda salpíngues com palhetas duplas como as do aulós. O instrumento era muito utilizado para produzir os toques dos movimentos de guerra.

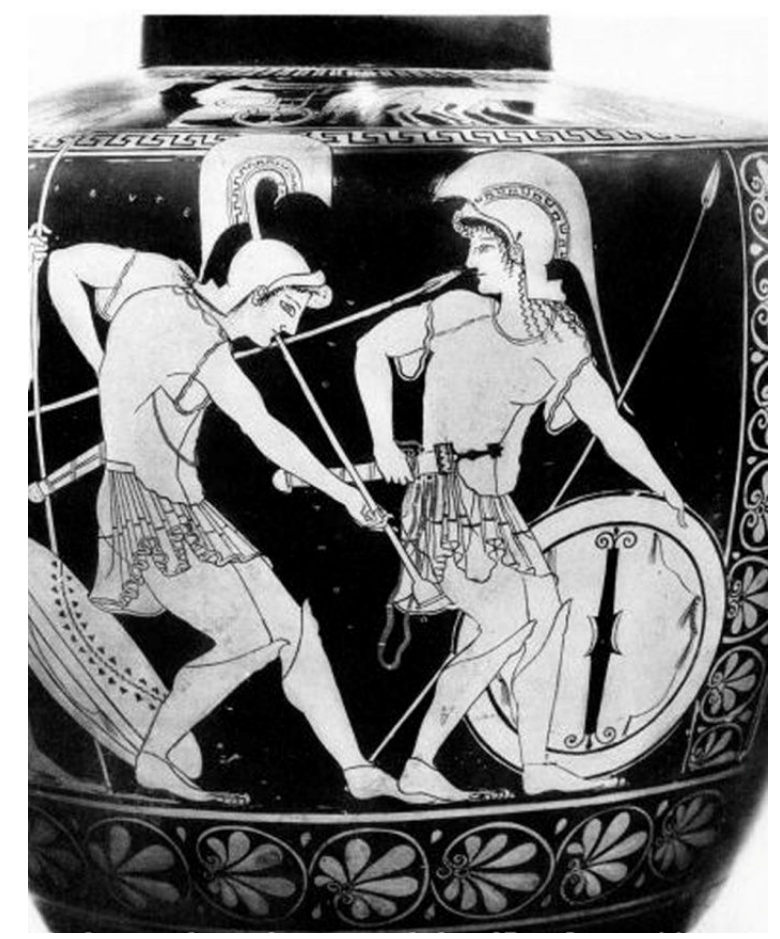

Fig. 11: Sálpinx: hydria ateniense, encontrada na Itália, com amazonas, uma delas tocando a sálpinx, c. 525-475. Artefato assinado por Hypsis.

A aparição constante dos instrumentos musicais na poesia requintada de Homero nos faz inferir também que uma música extremamente refinada era produzida, no que tange às suas inflexões vocais e no ritmo, sonoridade e variações improvisadas dos instrumentos. Na sociedade que descrevem, os músicos profissionais gozavam de status social. Não são escravos que cantam e tocam, mas músicos respeitados, quando não deuses e heróis, como Apolo e Aquiles. 
$\mathrm{Na}$ Odisseia há uma cena que mostra de maneira vívida a circunstância de performance dos aedos. Odisseu, no seu périplo de retorno à Ítaca, chega à Feácia como forasteiro e é convidado à corte de Alcínoo para ouvir o rapsodo Demódoco, amado das Musas:

$\mathrm{O}$ arauto Pontônoo trouxe para o aedo um trono trabalhado em prata e o encostou numa coluna no centro dos convidados. Pendurou ali uma sonora phórminx, sobre a cabeça e ao alcance das mãos do aedo; à sua frente colocou uma mesa com um cesto de pães e uma taça de vinho, para quando o coração desejasse (vv. Canto 8, 63-70).

A presença do trono de prata é um detalhe da movelaria desenvolvida pelos gregos que Homero não pode deixar passar despercebido, mas o aedo que senta ali é Demódoco. Ele canta a história da guerra de Troia, de Aquiles e do próprio Odisseu que, ao ouvir a narrativa de si mesmo, começa a chorar, sendo reconhecido pelos convidados. Mas não são apenas músicos profissionais que aparecem na Ilíada e na Odisseia; há ainda músicos amadores, como pastores e Aquiles - que é um guerreiro, que, como vimos, é capaz de cantar e tocar uma phórminx.

Homero faz menos referências ao aulós que à phórminx, fato que pode ser explicado pela posição que esta ocupava nesse período, ou seja, como instrumento profissional dos rapsodos, e que pode ter sido o instrumento do próprio Homero. Como já apontamos, há indícios ainda de que o aulós tenha sido rejeitado em alguns momentos da história grega por ser identificado a um instrumento não-helênico, e frígio. Isso está retratado na Ilíada, justamente quando os frígios são descritos como aliados dos troianos, combatendo contra os aqueus. No acampamento dos troianos, o som que se ouve ao longe é o do aulós e da sýrinx.

Sempre que o olhar para o campo dos troianos volvia 
Admirava-se os muitos fogos que em frente brilhavam

Aulói e siríngues cantavam, do grande tumulto dos homens (Canto 10, vV. 11-13).

Homero descreve cenas que seriam da idade do bronze. Porém, não saberíamos se ele o faz tomando como referência a música e os instrumentos de seu próprio tempo ou da passagem para a era arcaica, se não cruzássemos os relatos das epopeias com as representações e os vestígios arqueológicos do período.

Assim, é possível afirmar que na idade do bronze, tanto nas ilhas quanto no continente, os princípios da produção musical por meio da vibração de tubos e cordas eram bem conhecidos. Podemos dizer ainda que, além do desenvolvimento dos formatos das harpas, liras, bem como de instrumentos de sopros como aulós, sýrinx e sálpinx, alguns dispositivos técnicos já estavam criados para a produção do som (plectro), para fixar a tensão ou afinação das cordas (kóllops), para servir de suporte ou apoio para o braço dos instrumentistas, e ainda para modificar o timbre do instrumento, como a campânula de chifre (kéras) do aulós frígio. Esses aspectos revelam a presença de uma música sofisticada.

Com a destruição dos palácios micênicos, a partir de 1200 a.C., houve um período caracterizado por uma "baixa qualidade artística e tecnológica" (Finley, 1990, p. 80) com a interrupção dos contatos com o Oriente, o desaparecimento da escrita e o retorno da população à atividade pastoril. Os estudiosos que se baseavam apenas na documentação textual consideravam que a desintegração do sistema palaciano micênico tivesse sido o resultado da chamada "invasão dórica"; porém, investigações arqueológicas sistemáticas mais recentes mostraram outras possibilidades, como uma revolta da população contra os poderosos e ainda fenômenos ambientais. 0 desparecimento da escrita explica-se certamente pela extinção do 
sistema palaciano, uma vez que ela atendia a uma função administrativa e não teria por que continuar existindo.

O grande desconhecimento acerca do período subsequente à idade do bronze, a partir do século XI a.C., levou-o a ser chamado de Idade Obscura ou das Trevas. Outra denominação é Idade do Ferro, uma referência ao metal que se tornou mais importante que o bronze, o qual deixou de ser produzido por conta da escassez de estanho com a diminuição do comércio no Mediterrâneo. Não há vestígios de grandes edificações em pedra nesse momento, e pouquíssimos de guerras ou guerreiros. Nas cerâmicas da Idade do Ferro não há representações pictóricas, portanto, não temos registros de instrumentos musicais. Contudo, sabe-se hoje que o período não foi de pura estagnação. Essas informações vêm de regiões periféricas, como a ilha de Chipre onde se manteve o estilo pictórico.

No final desse período obscuro, começam a surgir representações nas quais percebe-se pouca variação técnica em relação aos instrumentos cicládicos, minoicos e micênicos. Uma exceção é um pequeno bronze, fundido provavelmente na passagem do século IX para o VIII a.C., em que aparece uma figura sentada tocando um instrumento como uma lira (Fig. 12). Nele, há uma barra curva presa à caixa de ressonância que deve ter sido "por séculos o dispositivo para prender as cordas na parte de baixo" do instrumento (Maas e Snyder, 1989, p.9). 


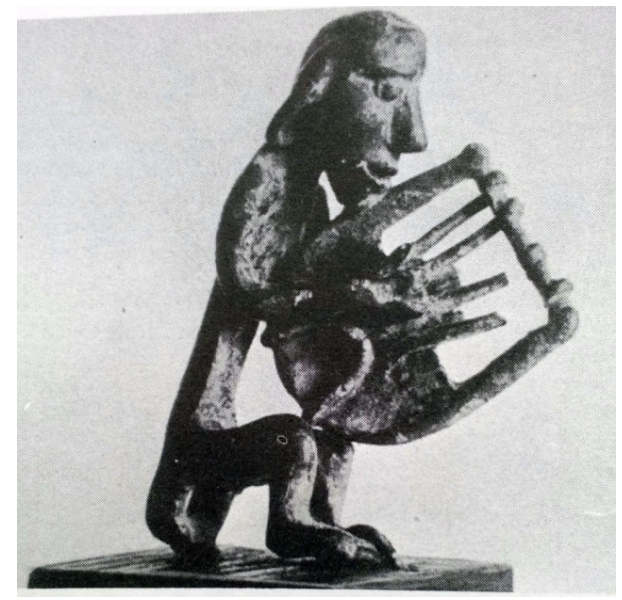

Fig. 12: Figura de bronze com músico sentado. Museu de Heraklion em Creta, Grécia, c. 1100-800 a.C.

Essa barra segue o mesmo princípio e tem a mesma função dos estandartes dos instrumentos de corda modernos, ou seja, manter as cordas afastadas do tampo do instrumento e, ao mesmo tempo, transmitir o som para o interior da caixa de ressonância.

No final do chamado período geométrico da arte pictórica grega, século VIII a.C., uma figura que aparece em um fragmento de cerâmica de Esparta mostra uma phórminx com grandes alças nas laterais, nas extremidades da barra superior de fixação das cordas, e uma grande caixa de ressonância. Se considerarmos alguma fidelidade do artista em relação à cena pintada, a civilização micênica havia aperfeiçoado a phórminx consideravelmente durante a Idade das Trevas (Fig. 13). 


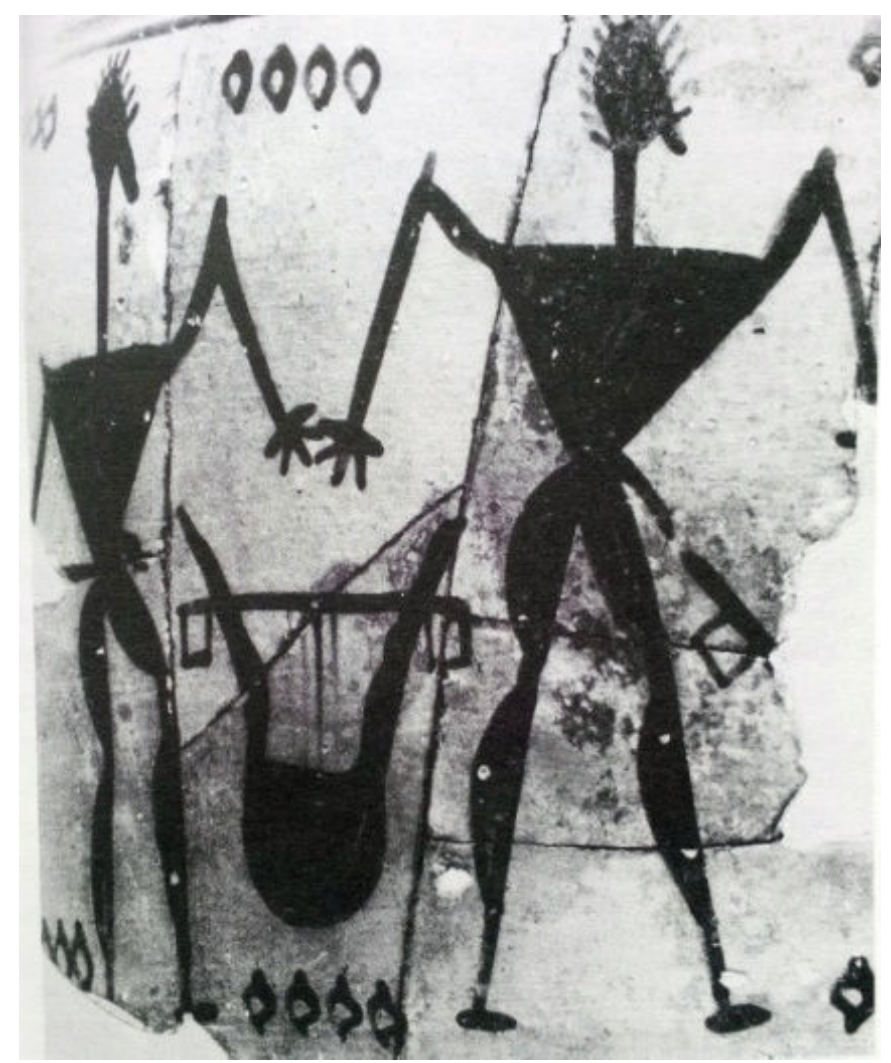

Fig. 13: Detalhe de pintura geométrica em vaso, com instrumento em que aparecem alças laterais, c.900 a.C.

As circunstâncias materiais da Idade do Ferro levaram a transformações nas práticas culturais. Lentamente foi se criando uma comunidade helênica, que apresentava uma unidade muito maior que a das tribos da Ilíada e na Odisseia. 


\section{Capítulo 2 - AS RETÓRICAS DAS TECHNAI}

\subsection{As musas da renascença grega}

Por volta de 1050 a.C. há uma primeira migração do continente grego para a Anatólia, ou Ásia Menor, região que corresponde hoje à maior parte da Turquia. De acordo com Finley, essas migrações são ainda obscuras e talvez não passassem de deslocamentos ocasionais e incertos. Mas logo "toda a orla ocidental da Ásia Menor tornou-se grega, e o Egeu converteu-se pela primeira vez numa via marítima grega, por assim dizer" (Finley, 1990, p. 82).

No final do século IX a.C., as populações dispersas começam a se reorganizar e, a partir do século seguinte, inicia-se um processo de fortalecimento das instituições. Uma série de inovações marca esse momento em que se desenham os germes da pólis como centro político, da moeda como valor simbólico de troca e da escrita fonética alfabética. Há um movimento de legitimação de um passado glorioso, dos deuses e heróis retratados na Ilíada e na Odisseia, que são colocados em escrita nessa nova era, mas cuja camada temporal que pretendem descrever ainda é a da idade do bronze.

A cultura arcaica volta seu olhar para esse período anterior, de cerca de quatrocentos ou quinhentos anos atrás, no qual estaria o mundo dos antepassados míticos dos helenos. Em nenhuma das epopeias está relatada a destruição dos palácios minoicos e micênicos. Há uma espécie de continuidade que se perde na bruma dos tempos. Como diz Finley, referindo-se à idade do ferro: "A arqueologia moderna descobriu um mundo pré-histórico jamais sonhado pelos gregos da era histórica" (1990, p. 79).

O termo "arcaica" não deve nos remeter à ideia de uma cultura limitada e sem recursos, pelo contrário, esse foi um momento de transformações fundamentais no mundo grego em termos econômicos, sociais e culturais. O período, que se estende até o VI a.C., é também chamado de Renascença por alguns estudiosos, por guardar 
semelhanças com a era italiana de mesmo nome. Como já apontamos, para muitos musicólogos esse é o momento em que começa propriamente o que se denomina música grega antiga. Os gregos constituíram nesse momento sua unidade, que eles mesmos denominaram Hélade, a terra dos helenos.

Por volta de 750 a.C. as póleis, como cidades-mães, começaram a promover migrações para expandir a Hélade, de início para a Itália e em seguida rumo a nordeste com as povoações na Trácia. Dava-se o nome de apoikías a esses povoamentos, que não eram colônias como as concebemos, pois elas não eram dependentes política ou economicamente das cidades-mães. Nesse momento há uma intensificação do comércio com os fenícios, os sírios e outros povos do Oriente Médio.

Ainda não é a pólis clássica, mas já existe a ágora, reservada às atividades políticas e religiosas. Em vez de palácios, como os minoicos e micênicos da Idade do Bronze, são construídos templos, que não serão mais locais de culto de um único génos, uma única família, mas de toda a comunidade. Para a defesa, são criadas a acrópole no ponto mais alto da cidade e as falanges hoplitas, exércitos de cidadãos fortemente armados, que defendem o território da pólis em tempos de guerra. Os mitos fortalecem a identidade cultural. Narrados no hexâmetro dactílico, eles foram tomados pelos helenos como seu passado mítico. Essa história não era transmitida por sacerdotes, e sim por poetas, mas que gozavam de uma aura de prestígio, detentores de um poder mágico, o da memória de um povo. Toda essa magia era acentuada pelo ritmo, pelas inflexões da voz e pelo domínio técnico dos instrumentos musicais. Como diz Havelock, o cantar dos poetas era dirigido diretamente ao público que estava diante do artista, as pessoas participavam como uma verdadeira manifestação popular (Havelock, 1982, p.147-162).

No gênero épico, do qual compartilham a Ilíada e a Odisseia, a narrativa do poeta pretende rememorar algo que não pertence à sua 
memória particular, mas à de toda a Grécia: a história dos helenos. Nessa tradição viva, quem conta um conto aumenta um ponto ou cria novos ângulos e perspectivas. Apresentados à assistência presente, os poemas eram recontados constantemente por outros poetas que, ao transmitirem as mesmas histórias, as recriavam. A poesia, como mecanismo de transmissão da cultura, tinha no ritmo e na música auxiliares poderosos para a memória: ${ }^{6}$

Um poema é mais memorizável que um parágrafo em prosa; uma canção é mais memorizável que um poema. Os gregos designaram esse complexo de práticas orais pelo termo técnico mousiké, e corretamente designaram as musas que deram nome a essa arte de "filhas da Memória" (Havelock, 1982 p. 189).

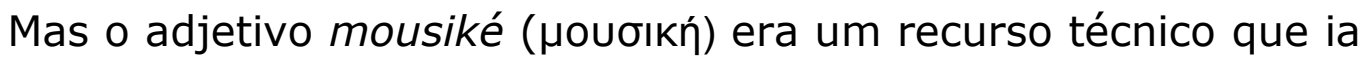
além do registro mnemônico das práticas orais. Não é possível nos contentarmos com a tradução usual do termo mousiké como "arte das musas". Em primeiro lugar, a tradução mais próxima para "arte", tal

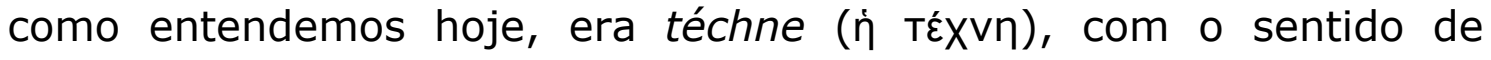
habilidade na produção de algo. A raiz indo-europeia |tech refere-se à ideia de produzir, e téchne seria produzir algo com habilidade. $\mathrm{Na}$ concepção de belas-artes desenvolvida posteriormente no Ocidente, a técnica é uma ferramenta da arte, mas na cultura grega téchne era a própria arte. O termo mousiké então parece apontar para um campo de sentido diferente. A tradução mais correta seria apenas "aquilo que é das musas". Mas isso nos deixa sem outra saída, a não ser perguntar: mas o que eram as musas?

No período arcaico, as musas já deviam ser cultuadas popularmente havia muito tempo. Elas eram invocadas nos versos do

\footnotetext{
6 No livro 19 de Problemas aristotélicos, o autor menciona canções que teriam sido normatizadas por motivos mnemônicos, comparando-as com as leis: "por que chamamos assim os nómoi? Será porque, antes de se conhecerem as letras, cantavam-se as leis para que não se as esquecesse?" (2001, p.49).
} 
prelúdio inicial que os rapsodos faziam antes do canto do poema, marcando presença no exato momento desse esforço inicial de memória, quando o poeta tinha de trazer à tona a sua composição, colocando vivamente à plateia que o ouvia o desdobrar das imagens no tempo.

Por cantarem imensos poemas transmitidos oralmente, os aedos e rapsodos utilizavam o ritmo hexâmetro dactílico, que se tornou depois o ritmo da poesia épica, e as variações tonais, com acompanhamento instrumental, como pontos de apoio da memória. Outro recurso utilizado era o da linguagem formular tal como a estudada por Milman Parry na arte dos bardos sérvio-croatas, como já vimos aparecer na clara phórminx. ${ }^{7}$

Não se sabe ao certo o momento preciso em que esses textos foram escritos. Segundo Havelock, isso aconteceu "em algum ponto entre 700 e 550 a.C" (1994, p. 163), após terem sido recitados por séculos, e devem ter sofrido novas adaptações e inserções.

Os versos apresentavam um arcabouço de saberes elencados e transmitidos ao longo do tempo. Quando Odisseu narra a construção da sua cama ou diz como testar um arco, esse conhecimento se dissemina. Em outros momentos dessa poesia, os procedimentos técnicos aparecem dispostos como em um catálogo ou manual. Além de servirem à memorização, eles são também uma ótima oportunidade para imprimir ritmo e construir visualmente as cenas na imaginação da audiência.

Homero menciona que nove era o número das musas, mas não oferece mais detalhes. Será Hesíodo, o primeiro poeta da era arcaica ${ }^{8}$, na sua Teogonia, que lançará as sementes mais duradouras da tradição das musas na Grécia, e no Ocidente. Em seu canto, elas são filhas da

\footnotetext{
7 O norte-americano Milman Parry estudou a transmissão da poesia oral sérvio-croata nos anos 1930-40 e percebeu elementos comuns à poesia grega que também era transmitida oralmente (cf. Parry, 1971).

8 A datação dos poemas de Hesíodo é tema de debate entre os estudiosos. A respeito disso, ver Snyder \& Maas, 1989, p. 222, n. 4 e também Havelock, 1994, p. 180-2.
} 
deusa Mnemosyne, Memória, e de Zeus, o poder máximo. Assim, além da relação das musas com a faculdade da memória, elas interferem no poder político, por exemplo, suavizando as palavras dos reis nas decisões sobre alguma disputa (cf. vv.85-94).

Hesíodo invoca as Musas nomeando-as, pedindo seu auxílio para a rememoração da genealogia dos deuses e titãs que, no caso, vem a ser o próprio poema. São elas:

\begin{tabular}{|c|c|c|}
\hline Thálea & $\theta a ́ \lambda \varepsilon a$ & da festa \\
\hline Melpômene & 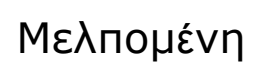 & do canto \\
\hline Terpsícore & 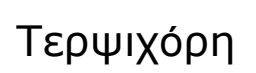 & da dança \\
\hline Eutérpe & 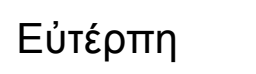 & da alegria \\
\hline Érato & 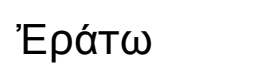 & das coisas amáveis \\
\hline Polímnia & 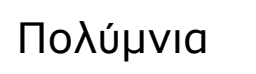 & dos muitos hinos \\
\hline Kalíope & 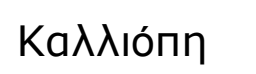 & do belo canto \\
\hline Kléos & 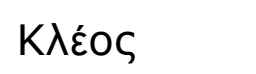 & do murmurinho \\
\hline Urânia & Oủpavín & das coisas celestes \\
\hline
\end{tabular}

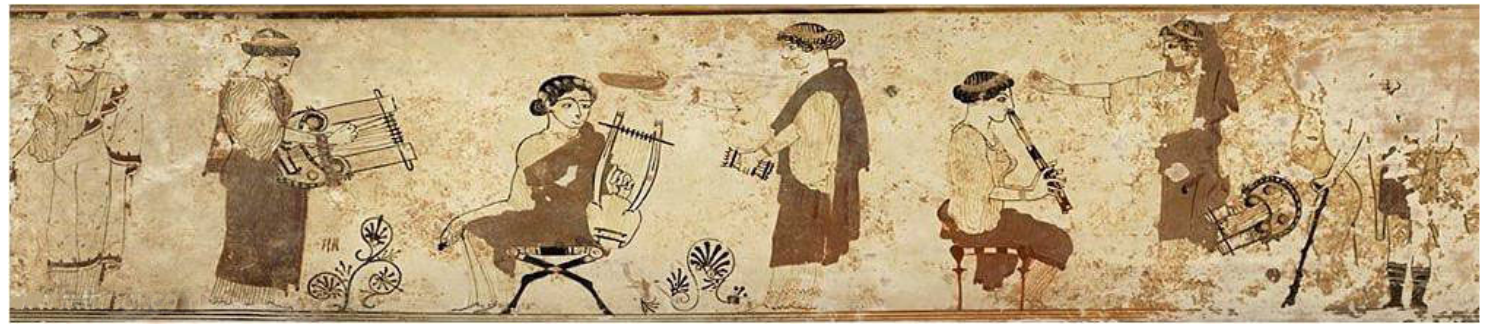

Fig. 14: Montagem da pintura no entorno de uma pýxis, que era uma caixinha para guardar remédio e outras substâncias; muitas das que restaram eram pintadas com cenas de música e musas. Nesta aparece o citaredo Thamyris à direita e as musas tocando instrumentos musicais, c. 460 a. C.

A presença de Urânia no panteão das musas evidencia uma fronteira difusa entre os planos do que chamamos hoje ciência e arte. Urânia representa o movimento dos astros e mais tarde será associada à ciência astronômica. Essas associações não aparecem em Hesíodo, apenas posteriormente serão designadas funções específicas para cada 
musa. No entanto, seus nomes nos dão algumas pistas. Todos trazem um sentido de movimento e/ou um certo rumor sonoro. Hesíodo pinta as musas dançando no alto do monte Hélicon em volta de uma fonte violácea, que é a representação da deusa Mnemosyne. Há um caráter vibratório na sonoridade dessas musas infatigáveis que cantam e dançam em torno de uma nascente vital. Segundo Hesíodo, o poeta não as vê, pois o alto do monte Hélicon é coberto de névoa. Hesíodo apenas ouve suas vozes e o bater de seus pés na terra. É uma epifania de sonoridades.

Como mostrou Torrano, as musas seriam a versão mais próxima que os gregos arcaicos tinham da noção de linguagem (cf. Torrano, 1971, p. 21-42). Assim, consideramos que a mousiké grega era a própria atividade de transmissão de um saber.

Ao longo do tempo, os poetas acrescentaram novos elementos às Musas de acordo com a sua inspiração, mas apenas no período clássico intensificam-se as suas representações e elas sempre portam instrumentos musicais. $\mathrm{Na}$ Renascença, os instrumentos serão pintados como alegorias de um saber ligado à ciência e à arte. Eles são objetos técnicos que, ao serem capazes de produzir um de seus componentes mais maravilhosos do som, o tom musical, mostram-se eficientes em dominar a sua natureza.

Os estudos etnomusicológicos nos alertam sobre os cuidados que devemos ter ao abordarmos uma música de outra cultura, que dirá de outro tempo. A música grega não tem uma sequência de transmissão contínua, tendo havido uma suspensão no início da Idade Média. A sua suposta retomada na Renascença está muito distante de sê-lo, senão pelas diferenças entre os sistemas musicais em si, também por conta das sonoridades diferentes dos próprios instrumentos; por exemplo, a kithára, instrumento central da música grega, não tem contrapartida em termos de timbre nos instrumentos musicais renascentistas. Também as Musas distanciam-se de sua mãe Mnemosyne, apesar de voltarem a ser invocadas pelos poetas. 


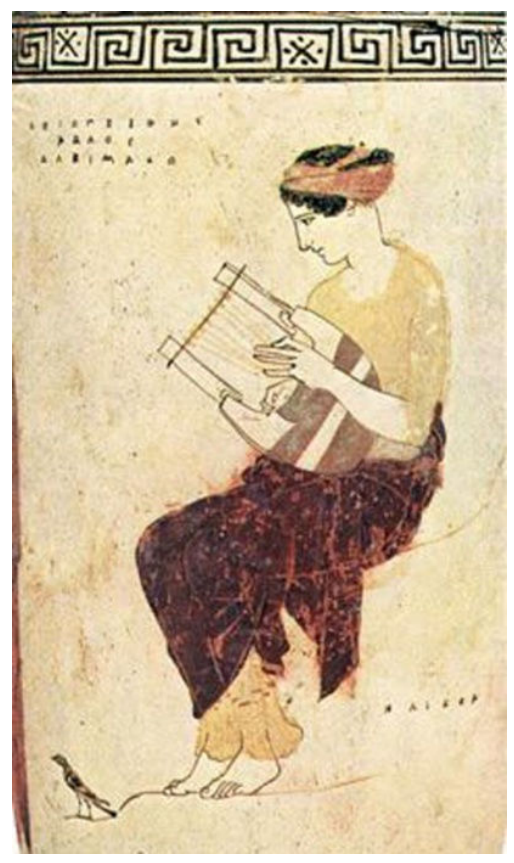

Fig. 15: Musa com phórminx sentada em uma rocha em que está escrita a palavra Hélicon. Vaso para guardar perfume, lekythos. Atenas, c. $440-430$ a. C.

\subsection{A ambígua filotecnia dos helenos}

Na obra Os trabalhos e os dias de Hesíodo, evidenciam-se as ambiguidades das conexões entre técnica, segredos mágicos e poder no horizonte cultural grego. No mito hesiódico, Prometeu rouba o princípio do fogo contido nos raios de Zeus, pondo em risco o reinado olímpico. Zeus decide então criar Pandora para punir os humanos, que haviam se beneficiado dos atos de Prometeu. Pandora criada é a própria natureza terrestre. Mas é um produto da téchne de Hefesto e Atena, deuses irmãos, detentores das artes metalúrgicas que Zeus convoca para criá-la.

Hefesto faz uma coroa em que estão representados todos os animais e o mar, Atena tece seu vestido e ensina-lhe a tecer. Zeus chama Hermes, Afrodite e seu séquito para dar-lhe o poder da sedução e ela é assim enviada aos humanos "comedores de farinha". Para VidalNaquet, esse epíteto dado aos mortais seria uma referência ao cultivo de cereais: "o epíteto homérico, alphéstes, o comedor de pão, está construído sobre a raiz edod, comer, paralelamente e em oposição a 
omestes, aquele que come cru" (1981, p. 43, n. 10). Zeus condena os humanos a trabalhar a terra para obter dela os frutos que os alimentam:

Os deuses mantêm escondidos os víveres dos humanos

Pois senão facilmente trabalharias para ter por um ano

E descansarias, colocando o arado em cima do fogão

Trabalhos penosos de bois e mulas seriam deixados de lado (vv.43-6).

Na mitologia, tal como presente em Hesíodo, Prometeu é o causador dos males, ao mesmo tempo em que trouxera o remédio. Ele é o culpado por um dos problemas básicos dos humanos: a fome. Sendo assim, o trabalho agrícola torna-se imperioso e pode tornar-se mais leve com conhecimento. Mas valorizar o conhecimento como técnica será um louvor indireto a Prometeu, podendo provocar a ira dos deuses, que têm o poder superior de prejudicar uma colheita. Esse jogo de espelhos entre téchne e natureza, humano e divino, artificial e natural desenvolve-se em uma tensão constante na cultura grega.

Em Hesíodo, aquilo que de início era uma punição de Zeus, vai se transformar em uma espécie de prêmio. Seu poema torna-se um louvor ao trabalho, pois "trabalhando, muito mais caros (os homens) serão aos mortais" (v. 310, 1996, p. 45). O trabalho do agricultor de Hesíodo ganha um valor de mérito, areté. O poeta mostra a agricultura como uma técnica que requer uma observação constante dos sinais dos astros, das estações, dos pássaros e o conhecimento de diferentes culturas, mas a contrapartida a ela é o suor. O mundo urbano, dos artesãos e da política, opõe-se ao rural, que depende da benesse das forças da natureza, ou dos deuses, para sobreviver. Hesíodo avisa seu irmão: "Não pares diante da forja e da ágora bem quente, na estação de inverno, quando o frio afasta do seu campo o trabalhador" (vv.4946). Mas as ambiguidades permanecem; Hesíodo descreve as etapas da 
fabricação de um arado, instrumento técnico que marca a sedentarização humana.

Então é que se há de cortar a madeira, é oportuna a sazão. Cortai um gral de três pés, uma mão de três côvados e um eixo de sete pés: são estas as melhores dimensões; se o cortardes de oito pés, podeis tirar dele também um malho. Talha uma roda de três palmos para um carro de dez palmos. São muitas as madeiras recurvas; levai para casa um apo, se encontrardes algum, procurando nos montes ou pelos campos, de madeira de azinho; é o mais resistente lavrando-se com bois, quando o servo de Atenas, depois de o haver fixado à sola, o ajustou ao temão com cavilhas. Afeiçoai dois arados, trabalhando em casa, um de uma só peça, o outro por encaixes, será assim muito melhor; se um se quebrar aporeis os bois ao outro. Resistem melhor à podridão os temões de loureiro e de olmo; a sola é de carvalho, o apo de azinheiro (vv.421-437).

O "servo de Atenas" que faz arrebites no arado de Hesíodo pertence ao grupo dos metalúrgicos, dos carpinteiros e dos tecelões, funções sociais que não tiram seu sustento da terra, mas, como diz Vernant, do comércio, suscitando um misto de temor e menosprezo.

Contradições psicológicas que, mais do que por uma dualidade de origem, explicam-se talvez pelos sentimentos confusos de temor $\mathrm{e}$ também de menosprezo, que parecem ter suscitado estas corporações de metalúrgicos, cujo status, práticas, segredos também os colocavam à margem do grupo social (Vernant, 1973, p. 211). 


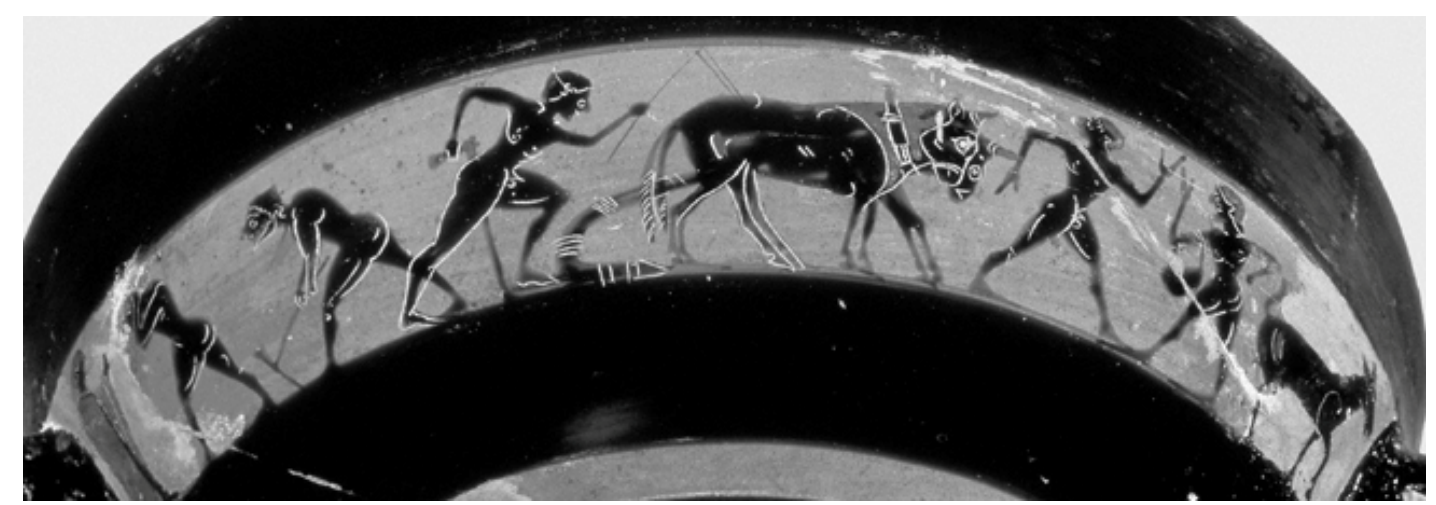

Fig. 16: Homem com arado de madeira.

No período clássico, uma vertente de preocupação com a técnica associa-a diretamente à ideia de comércio. Para Sócrates, a téchne sofística de Protágoras é tal qual a de um mercador, que vai de cidade em cidade oferecendo o que tem para vender. Sócrates considera que o mercador não tem compromisso com os valores que porventura estejam associados àquilo que vende, assim como a técnica sofística. (cf. Platão, 313a). Esta é associada à moeda e à política. Por seu lado, Protágoras diz que, com ele, os jovens se tornarão melhores no cuidado especial em seus negócios pessoais, de modo que terão poder na pólis, tanto como orador quanto homem de ação. Ele argumenta que seu ensino é diferente, pois pretende inspirar os jovens às boas ações

tal como os kitharistái (professores de lira) (inspiram) os jovens ao autocontrole e à temperança em vez das más ações; desse modo, depois de eles terem aprendido a tocar a lira (kytharízein), eles os ensinam os grandes poetas líricos, que então eles acompanham na lira, familiarizando as mentes das crianças com os ritmos e as melodias. Desse modo, eles se tornam mais civilizados (hemeróteroi), mais equilibrados e mais ajustados em si mesmos e assim mais capazes em qualquer coisa que façam ou digam; pois ritmo e ajuste harmonioso são essenciais a toda vida humana (326 a-b). 


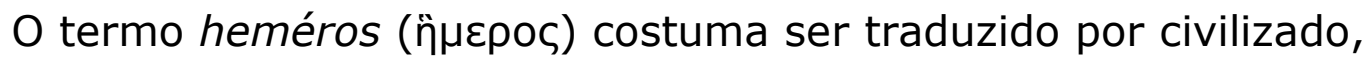
mas sua primeira acepção é domesticado, não selvagem. Para Protágoras, efetivamente é preciso aprender uma téchne para viver nas cidades e, para ilustrar o ponto, conta um novo mito de Prometeu. Nessa versão, há uma alusão aos artesãos que ocultam seus segredos, pois Prometeu rouba o fogo e as técnicas da oficina de Hefesto e Atena: "[ele] roubou de Hefesto e Atena a sabedoria técnica junto com o fogo, pois sem o fogo era impossível qualquer um possuir ou usar essa técnica - e doou-a ao ser humano" (321d). Desde então, o ser humano tem um parentesco com os deuses, e por isso que é a única criatura que acredita neles.

Com a técnica, os humanos descobriram o discurso articulado e os nomes, inventaram as roupas, os calçados e as camas, e tiraram o alimento da terra. Mas não havia cidades e eles eram devorados pelos animais. E então foi preciso se reunir e criar a pólis. Mas embora reunidos e conhecendo a agricultura e a arte dos demiurgos, isso não era suficiente para fazer a guerra com as feras, pois os humanos não possuíam a técnica da política, da qual a guerra é uma parte (cf. 322 a-c). Esse é um momento crítico do diálogo em que a técnica sofística e a política são apresentadas como artes de domesticação das feras. É essa arte retórica que Protágoras ensina a seus alunos, para ter poder de persuasão na ágora. O diálogo de Platão vai discutir então se a arte política é uma técnica de persuasão ou se é uma defesa de valores e se isso é ou não, ensinável.

Assim, a téchne, tanto no mito hesiódico quanto na narrativa de Protágoras, nasce respectivamente de um roubo e de uma carência. $\mathrm{Na}$ Teogonia, Hesíodo nomeia Prometeu pelo epíteto poikílon

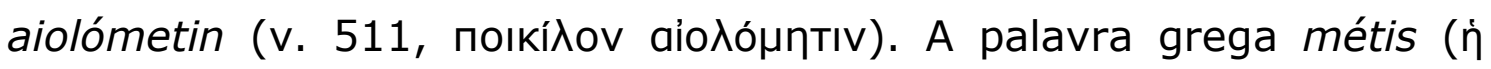
$\mu \tilde{n} T I \zeta)$, presente no segundo termo, aparece no nome de Prometeu e de seu irmão Epimeteu, e é um substantivo que tem seu campo semântico personificado numa deusa, Métis, a primeira esposa de Zeus. O termo pode significar vários tipos de conhecimento, sabedoria 
ou prudência, sempre com ênfase na eficácia prática: o domínio do artesão sobre sua técnica, artifícios mágicos, a utilização de beberagens e ervas, recursos de guerra, ilusionismo, disfarce e artimanhas de todo tipo. Mas métis significa também o ardil que se utiliza de truques, mentiras e engodos para atingir seu objetivo. A deusa Métis é dona do olhar fixo, antípoda da impulsividade. É rápida, mas também densa e paciente. Possui o peso da experiência que aguarda a oportunidade, o bom momento, kairós (ò kaıpós). Seu movimento rápido, aiólos (aió uma ondulação, um jogo de reflexos, tal como uma vibração incessante

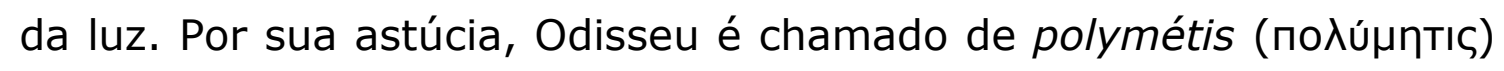
por Homero, assim como Dédalo. O inventor do labirinto de Creta é tido também como criador de muitas ferramentas como a tesoura, o machado, o fio de prumo, a roda e o compasso, mas também das tortuosidades do labirinto.

No período arcaico, o fogo de Hefestos associa-se às inovações que estão surgindo, como a cunhagem de moedas. O deus Hefestos aprendeu sua arte durante os nove anos que passou no fundo do mar

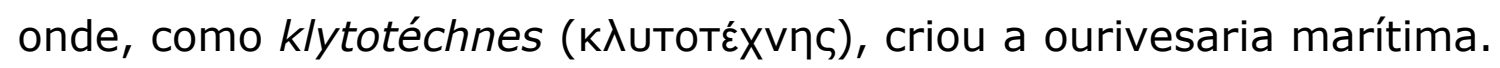
É Hefestos, o deus torto, quem faz as armas de Aquiles e os autômatos para o serviço dos deuses.

Alça-se logo do banco da incude o disforme ferreiro a coxear, afanoso, nas pernas recurvas e bambas.

Tira das chamas os foles, depondo os demais utensílios, Com que folga ocupar-se, numa arca de prata maciça.

Com uma esponja, depois, limpa o suor e as escórias do rosto, De ambas as mãos, do pescoço robusto, do peito veloso E pós vestir alva túnica, sai a coxear da oficina, Num cetro forte apoiado, ladeado por duas estátuas De ouro, semelhas a moças dotadas de vida, pois ambas Entendimento possuíam, alento vital e linguagem (Ilíada, Canto 18, vv. 410-419). 
Os autômatos de Hefestos não estão aqui como um elogio à arte mecânica, mas para provocar o temor com essa insinuação terrível da téchne no âmbito das criações da natureza ${ }^{9}$. Para os gregos, a téchne tem um sentido produtivo inequívoco. Ela é uma virtude do âmbito prático, e quem a detém sabe como operar sobre uma certa natureza em particular. Pode ser um ferreiro, um construtor de aulós, um sapateiro ou um poeta.

Na tragédia arcaica Prometeu acorrentado, de Ésquilo, cuja elaboração situa-se entre o poema de Hesíodo e os diálogos de Platão, o titã é enaltecido como o benfeitor da humanidade. Ésquilo é o primeiro dos três grandes tragediógrafos gregos, tendo sido o vencedor das Grandes Dionisíacas em 472 a.C. com Os persas, a mais antiga tragédia a sobreviver completa. A vitória sobre os persas havia ocorrido em 480 a.C, em Salamina, onde o próprio Ésquilo combateu. O afastamento definitivo da ameaça oriental arrebatou os gregos em sua auto-imagem civilizatória.

A data de apresentação de Prometeu acorrentado é incerta, mas ocorreu após a erupção do vulcão Etna em 479/8 a.C., evento mencionado na peça. Na tragédia, Zeus representa a tirania de um poder político desumano e Prometeu, a função técnica.

No segundo episódio, Prometeu, já agrilhoado, fala ao Coro quais foram as suas dádivas aos seres humanos, a quem chama de "novos deuses". Diversas técnicas são enumeradas, representando o arcabouço do conhecimento que os gregos possuíam até então.

No começo, eles olhavam e não viam, escutavam e não ouviam, passavam a vida alongada e néscia como sombra de fantasias. Não conheciam as casas soalheiras e feitas de tijolos, nem a madeira

\footnotetext{
${ }^{9}$ No século XVII a ideia da natureza dupla e tortuosa da téchne foi tematizada por Francis Bacon justamente na figura de Hefesto, o prótos eurétes do fio de prumo: "foi o mesmo homem que inventou as armadilhas do labirinto e mostrou a utilidade do fio. As artes mecânicas são de fato como duplas em seus usos, elas produzem o mal e o remédio, e sua virtude, de qualquer modo, se/a desfaz e se/a liberta dela mesma" (Bacon, 1997, p. 114).
} 
trabalhada. Viviam em cavernas, nas eternas trevas dos profundos antros, como formigueiros fervilhando. Não possuíam signos para o inverno, nem para a florida primavera, nem para o fecundo verão. Faziam tudo sem entendimento, até eu Ihes ensinar o nascimento e o ocaso das estrelas mais difíceis de avistar. Para eles inventei o número, suprema sabedoria, e a arte de juntar as letras, memória de todas as coisas e infatigável mãe das Musas. Fui o primeiro a submeter ao jugo e ao carrego os cavalos selvagens para que ajudassem os homens nos trabalhos mais fatigantes; fui o primeiro a atrelar à carruagem, ornamento de magnífica riqueza, os cavalos submissos ao freio. Primeiro e sozinho eu congeminei os velívolos carros dos marinheiros que vagueiam pelo mar (...)

Dantes, se um homem era colhido por qualquer enfermidade, não possuía nem remédios, nem bálsamos, nem alimentos, nem poções. Os homens definhavam por ignorarem os medicamentos, antes de eu Ihes ensinar as misturas das mezinhas benfazejas que hoje Ihes saram todas as moléstias. Ensinei-lhes também muitas formas de vaticínio; fui o primeiro a ilustrá-los sobre que sonhos devem ser realidade e aprouve-me revelar-lhes previsões dificílimas de adivinhar a respeito das viagens.

Observei atentamente o voo das aves de garras aduncas, revelando as que são por natureza faustas ou infaustas; como revelei o sustento que nutre cada uma, os amores, as convivências, as inimizades existentes entre elas. E qual macieza e cor devem ter as suas vísceras para que se tornem agradáveis aos deuses. E o multiforme aspecto favorável da bílis e do fígado. Iniciei os homens na arte difícil de queimar os adiposos membros e o osso sacro das vítimas. Tornei claro aos seus olhos os signos do fogo, que antes lhes estavam encobertos e obscuros.

Tais foram as minhas dádivas... E quem se atreve a dizer que descobriu antes de mim todas as coisas úteis para o homem, ainda ocultas debaixo da terra, o cobre, o ferro, a prata, o ouro? Não será quem tiver 
consciência do que afirma. Em suma: foi de Prometeu que os mortais receberam todas as artes (Ésquilo, 1984, p. 41-43).

As técnicas agrícolas, o alfabeto, a astronomia, a domesticação dos animais e os meios de transporte por terra e por mar, a medicina seguida da arte divinatória, a religião, a metalurgia. Todas as técnicas são criadas para tornar mais leve a existência humana. A téchne simboliza a vida civilizada, o que fornece o seu fundamento.

Burford observa que o Prometeu acorrentado de Ésquilo foi escrito numa época em que houve uma reafirmação dos valores culturais de Atenas, "simbolizada pela reconstrução de templos espalhados e a enfatização do culto de Hefestos em particular" (1972, p. 189). O bairro dos artesãos situava-se próximo ao templo do deus metalúrgico (Fig.17). 


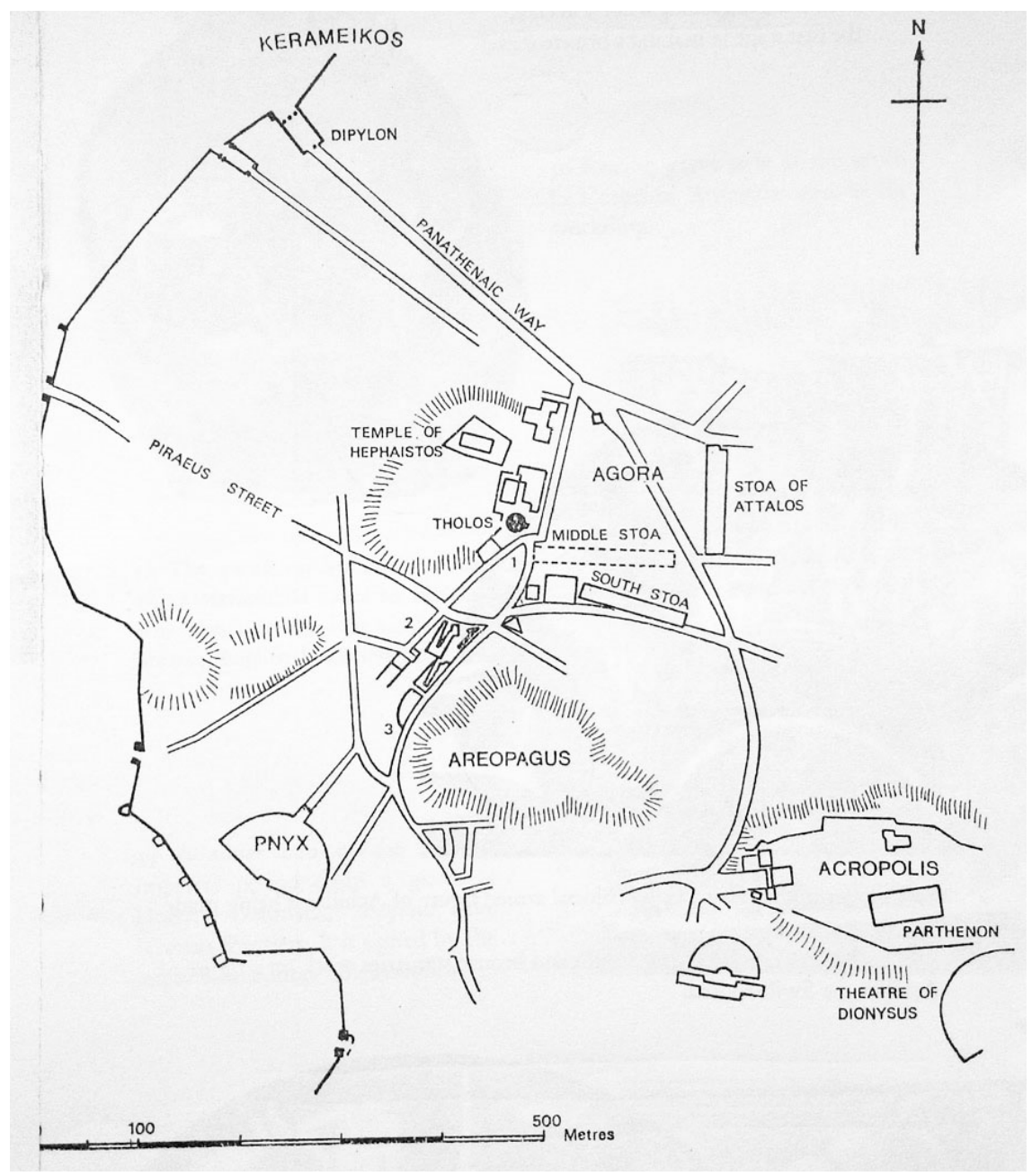

Fig. 17: 1) casa de Simão, o sapateiro; 2) rua dos trabalhadores em mármore e 3) cemitério arcaico. No alto, acima, Kerameikos, o bairro dos ceramistas.

Dentro do espírito agonístico grego, cada cidade reclamará a sua excelência técnica. Em Atenas havia ainda competições entre os ceramistas.

Com que frequência ocasiões desse tipo aconteciam nós não sabemos, mas provavelmente a disputa de ceramistas em Atenas fazia parte de um festival, no qual a comunidade celebrava a téchne de seus artífices fazendo-os exibir-se uns contra os outros e dando a oportunidade de vencer os rivais de outras regiões (Burford, 1972, p. 211). 
Burford refere-se a evidências arqueológicas que mostram a versatilidade dos artesãos atenienses nas escavações realizadas no bairro dos artífices, onde foi possível identificar diversas modalidades.

Muitos dos artesãos de quem conhecemos os domicílios viveram em locais a oeste da ágora - Kerameikos (originalmente local dos ceramistas), Kolonos Agoraios, Melite e Kollytos; a casa de Simão o sapateiro ficava na fronteira mais ao norte do Kydathnaion, o demos da acrópole. As concentrações mais pesadas de atividade industrial encontradas até hoje são as fundições de bronze e as oficinas dos ceramistas em volta e no próprio templo de Hefestos, que datam do período anterior à metade do século $V$ e as várias oficinas no vale entre a Colina das Ninfas e o Areópago. Uma seção nesta área, chamada de Rua dos Trabalhadores do Mármore por aqueles que fizeram as escavações, continha vários estabelecimentos de trabalho com pedra, uma ferraria e em períodos diversos várias oficinas de escultura em terracota (Burford, 1972, p. 211).

Diante das evidências literárias e arqueológicas da centralidade que tinha a téchne para os gregos, percebe-se que as observações de filósofos como Platão e Aristóteles em relação às atividades técnicas correspondem a uma tensão aguda que esse campo suscitava na sociedade grega.

No diálogo Protágoras, Sócrates nos conta que, quando as decisões tomadas na ágora diziam respeito a algum assunto técnico, os demiurgos eram consultados, mas quando os assuntos eram concernentes à pólis, todos eram ouvidos: construtores, ferreiros, sapateiros, comerciantes, armadores, sendo ou não do génos (cf. 319d). Protágoras concorda: "pois é razoável que teus cidadãos acolham, no que diz respeito às coisas públicas, os conselhos de um

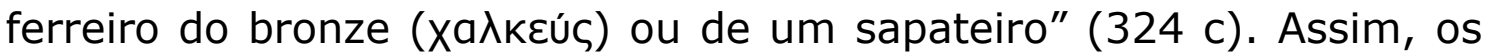
artesãos tinham status político, ao menos na sociedade ateniense do século $V$ a.C. 
Mas Sócrates deixa claro, no início do mesmo diálogo, que há uma diferença entre os demiurgos e os homens livres, entre aquele que aprende algo por interesse comercial e o que aprende para seu proveito próprio. Ele pergunta a Protágoras se o seu ensino será como a educação do cidadão livre, tal como

daqueles que ensinam letras, citarística e ginástica; cada uma dessas coisas você não aprende pela técnica (

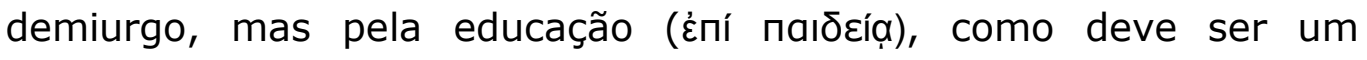

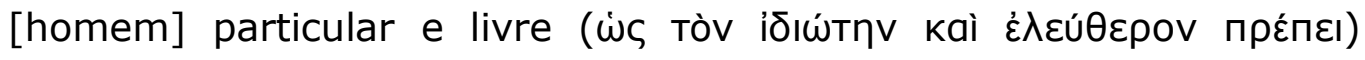
(312b).

Para esses filósofos, aqueles que recebiam instrução para o exercício de uma técnica deviam ocultar seus conhecimentos para benefício próprio. Xenofonte os diferencia dos agricultores, pois a terra "não usa artifícios, mas com simplicidade, mostra sem mascarar e sem mentir aquilo que é capaz e aquilo que não é capaz" (Xenofonte, Economica, XIX, 17, apud Vernant, 1973, p. 223). Protágoras também afirma que sua técnica sofística não é "tal como ocultam os [que

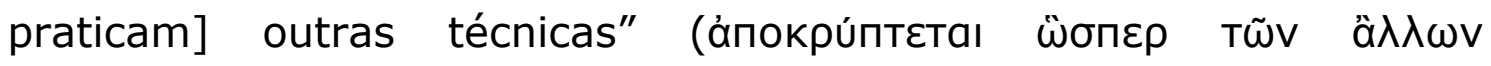

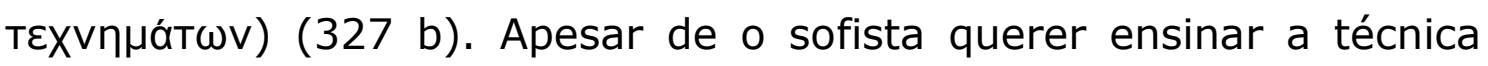

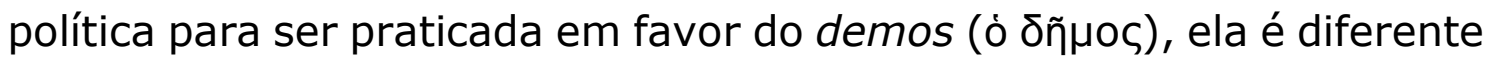
daquela do demiurgo, que tem interesse financeiro, levando-os a manterem ocultos seus segredos.

Sócrates contrapõe a educação do cidadão livre à do demiurgo. Essa conviç̧ão de que aquele que se dedicasse a uma atividade técnica era inferior gerava ofensas como as dos inimigos de Sófocles, que o "acusavam" de ser filho de carpinteiro ou de mineiro, ou Kleophonte, que foi "acusado" de ser um lyropoiós. As atitudes valorizadas eram tais como as do pintor Polygnotos de Thasos, do século $V$ a.C., que pintou o Stoa Poikíle ateniense com seu próprio dinheiro. 
As oficinas dos artífices eram espaços de discussões e investigações da natureza. Em um julgamento realizado na Atenas do final do século $V$ a.C., a reclamação do acusador era de que a oficina de um determinado artesão seria um local de encontros de bandidos. A defesa alegou, no entanto, que "toda oficina em Atenas era um local de encontro, e que todos os atenienses tinham o hábito de frequentálas, especialmente aquelas perto da ágora" (Burford, 1972, p. 156). Mais uma evidência de que os gregos fizeram das oficinas um lugar onde o seu espírito investigativo nunca cessou de habitar.

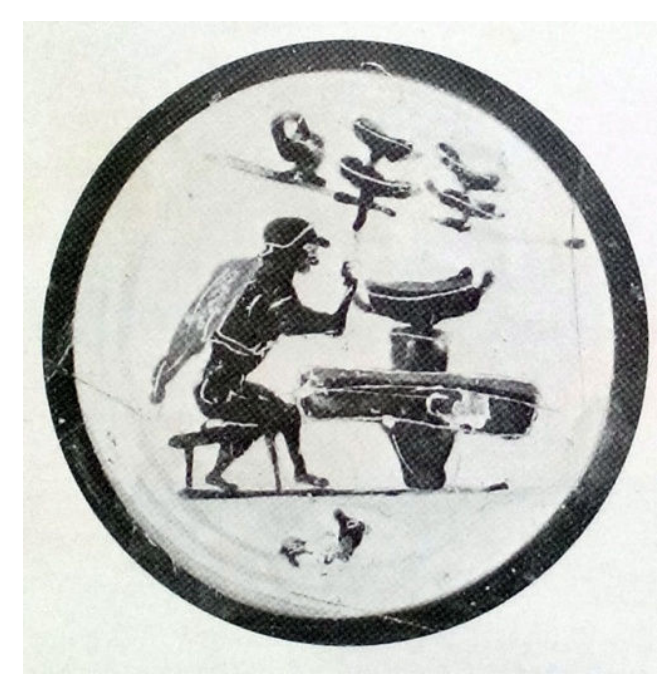

Fig. 18: Ceramista trabalha em uma taça aberta com alças, kylix, em sua roda de oleiro.

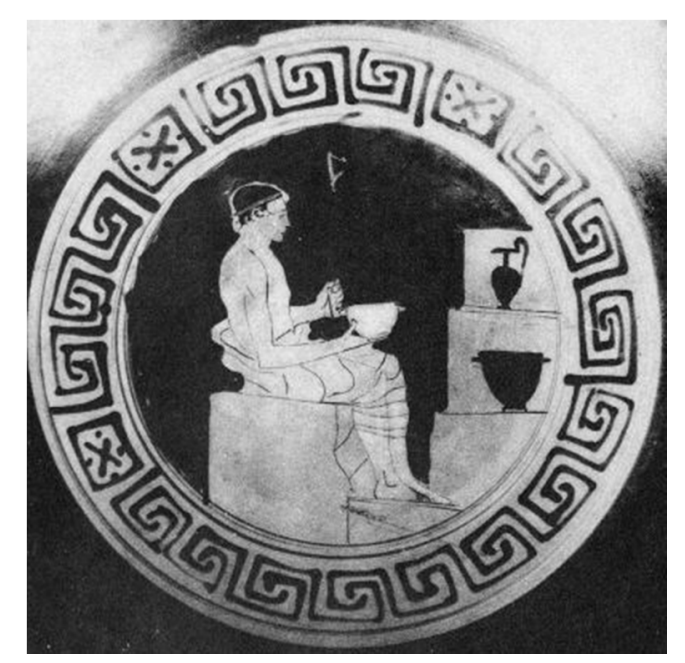

Fig. 19: Ceramista faz o polimento de um vaso para tomar vinho, skyphos.

Xenófanes, nas Memorabilia, nos relata o périplo de Sócrates por várias oficinas, primeiro na casa do pintor Parhasius, onde pergunta ao artífice se ele teria um modelo perfeito de representação para a beleza da alma; depois segue à casa do escultor Cleifon e o questiona a respeito de como cria a ilusão de vida em suas estátuas; por fim, chega à oficina de Pístias, a quem pergunta o que faz com que a sua armadura custe mais que a de outros artesãos. Pístias responde que é o fato de ela ser bem-proporcionada e confeccionada sob medida. Sócrates segue então: 
- E talvez tenha ainda outra vantagem importante numa armadura feita sob medida.

- Diga-me, se você sabe, Sócrates.

- A boa vestimenta é menos pesada para vestir que a ruim, embora ambas tenham o mesmo peso. A desajustada, que balança inteira nos ombros, ou pressiona alguma parte do corpo, mostra-se desconfortável e fatigante; mas a ajustada, com seu peso distribuído sobre a clavícula e as omoplatas, os ombros, o peito, as costas e a barriga, pode quase ser chamada de um acessório, em vez de um empecilho.

- A vantagem a que você se refere é aquela que eu penso que faz meu trabalho valer um bom preço. Alguns, no entanto, preferem comprar as armaduras ornamentadas e folheadas a ouro.

- No entanto, como o corpo não é rígido, e está em uma hora curvo, em outro momento reto, como as armaduras bem ajustadas podem ser boas?

- Não podem.

- Você quer dizer que não são as bem ajustadas mas aquelas que não friccionam os que a vestem?

- Esse é o seu próprio sentido Sócrates, você acertou na mosca. (Livro 3, cap. 10, 1-5).

A posição do artífice de armaduras parece bem diferente daquela do artesão que não é capaz de avaliar sua própria obra, pois dependeria daquele a quem vai vendê-la, tal como descreve Aristóteles o aulopoiós, que não pode julgar o instrumento que fabrica, apenas o auleta, ou seja, aquele que vai comprar o instrumento (1277 b). Pelo contrário, os aulopoiói deveriam ter um diálogo constante com os auletas, e certamente eram os que sugeriam mudanças na técnica de execução dos instrumentos, que por sua vez dependeriam dessas inovações na sua construção. Se não conduziram propriamente mudanças na linguagem, ao menos, criaram as condições necessárias para que fossem realizadas. Assim sendo, o aulopóios está longe de ser um simples intermediário. 
Dada a complexidade das tensões suscitadas pela questão da técnica na sociedade grega, não nos surpreende que Platão manifeste sua admiração e apreço por ela, reclamando para Atenas a virtude filotécnica, na voz do velho Crítias.

Agora, em outras regiões, outros deuses têm sua parte e ordenamento das tarefas que thes cabem e assim como Hefestos e Atena são de natureza semelhante, nascidos do mesmo pai, e concordando, acima de tudo por seu amor pela filosofia e pela filotecnia, ambos tomaram como sua região essa nossa terra, naturalmente congênita e adaptada para a habilidade e a sabedoria, e aqui eles plantaram como nativos deste solo homens de virtude e colocaram em sua mente o modo de governo (109c-d).

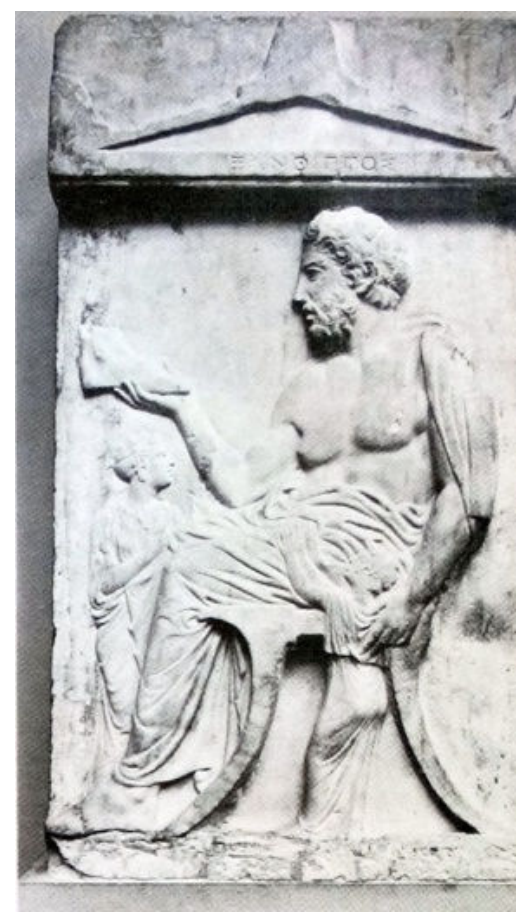

Fig. 20: Estela funerária do sapateiro Xanthipos de Atenas, c. 420 a.C.

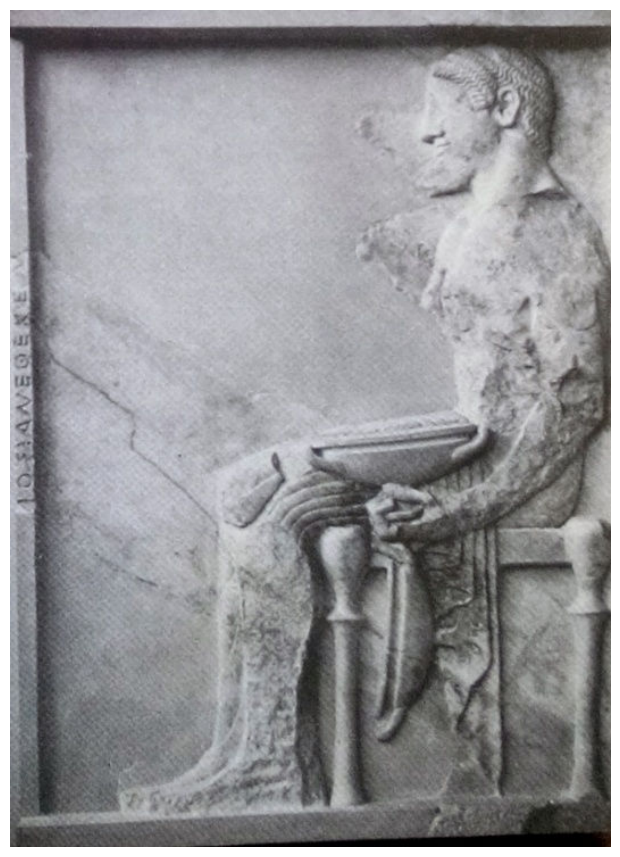

Fig. 21: Estela encomendada provavelmente pelo ceramista Pamphaios ao escultor Endoios, final do século VI a.C. 


\subsection{As associações mágicas da téchne}

Hesíodo, em Os trabalhos e os dias, associa a gênese da raça humana à técnica de preservação do fogo. Prometeu rouba o fogo dos raios de Zeus e o traz aceso no caule oco de um nártex. Considerado uma ousadia por Zeus, esse ato prometeico é o relato de uma técnica milenar desenvolvida a partir do conhecimento das propriedades específicas de uma planta. Essa espécie, o nártex, tem "caules ocos e suculentos, onde subsiste um óleo volátil de combustão lenta, que permite a conservação das chamas, sem queimar a madeira" (Penedo, 2009 , p. 3). Assim, o mito do "roubo do fogo" pressupõe uma atitude humana de acumulação gradual de saberes, que inclui o conhecimento dos usos das espécies de plantas, a "ciência do concreto" de LéviStrauss, a que já nos referimos.

Essa noção pode parecer contrastante com a de prótos heurétes,

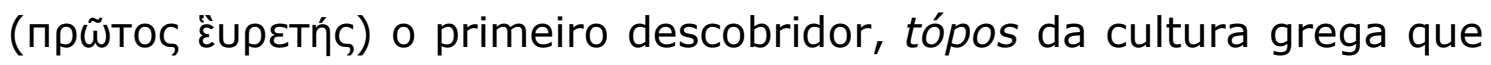
atribui a um deus, a um herói ou mesmo a um mortal a descoberta ou invenção de técnicas ou objetos, e mesmo ideias. Mas as duas noções não são necessariamente excludentes, pois mesmo um insight repentino ocorre em um contexto que conferiu as condições para que tal acontecesse, de novo, uma lenta acumulação de saberes relacionados. Em uma descoberta originária como a do fogo, que remete diretamente à capacidade humana de gerar energia para múltiplos fins, o prótos eurétes grego costumava ser um deus ou um herói.

Descobertas que envolvem técnicas de manipulação da natureza remetem a práticas mágicas. Na Grécia, no caso da metalurgia, ela

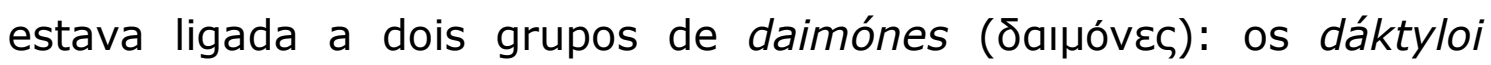

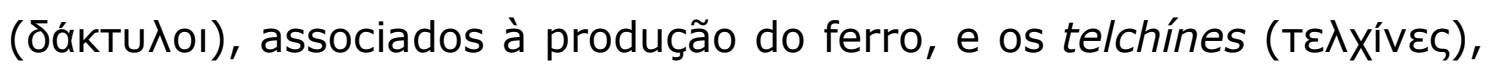
à do bronze. Ambos relacionavam-se também à música e à dança. Vernant faz referência a ambos dizendo que eles "teriam uma atividade mais mágica que guerreira, fabricantes de metais de um passado remoto, lendário" (1987, p. 227). Contudo, estudos recentes mostram 
que os daimónes em geral têm um campo semântico mais complexo e tiveram uma penetração ao longo de toda a cultura grega antiga, principalmente no âmbito popular, pois aparecem em provérbios e trocadilhos. Tantos os dáktyloi quanto os telchínes não aparecem na iconografia antiga, mas, de acordo com Blakely, as evidências a respeito dessas personagens estão presentes em "371 citações, 109 autores, durante dois milênios" (2006, p.27). A autora diz que, por sua complexidade, os daimónes permaneceram "na periferia dos estudos clássicos", mas

a dificuldade dos dados é compensada pela oportunidade que eles representam de investigar uma força mitológica única da força histórica e social da metalurgia, e suas relações com a medicina, a magia, o poder político e a performance poética $(2006$, p.7).

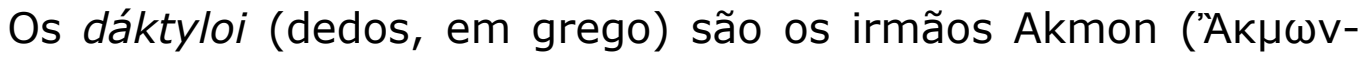
Bigorna), Damnameneús e Kelmis, que recebiam o epíteto Idáian Dáktyloi, os dedos do Monte Ida, ponto culminante da ilha de Creta. Esses daimónes eram também goetes (ó yontńs), cantores de lamentos fúnebres e de canções mágicas. O estudo de Blakely compara esses daimónes aos griots, clã da África ocidental que igualmente pertencia ao grupo que detinha o segredo da manipulação do ferro. Os griots existem até hoje no Mali e outras regiões e, além das qualidades de entretenimento, são comumente chamados a ministrar canções mágicas para cura de doenças e picadas de animais peçonhentos. Estudos comparativos podem ser válidos se guardadas as devidas distinções; e nesse sentido, segundo Blakely, os estudos relacionados à técnica metalúrgica,

são interessantes porque as condições requeridas para a produção metalúrgica como combustível abundante, altas temperaturas e um trabalho que é tão habilidoso quanto extenuante, são universalmente análogas (2006, p. 5). 


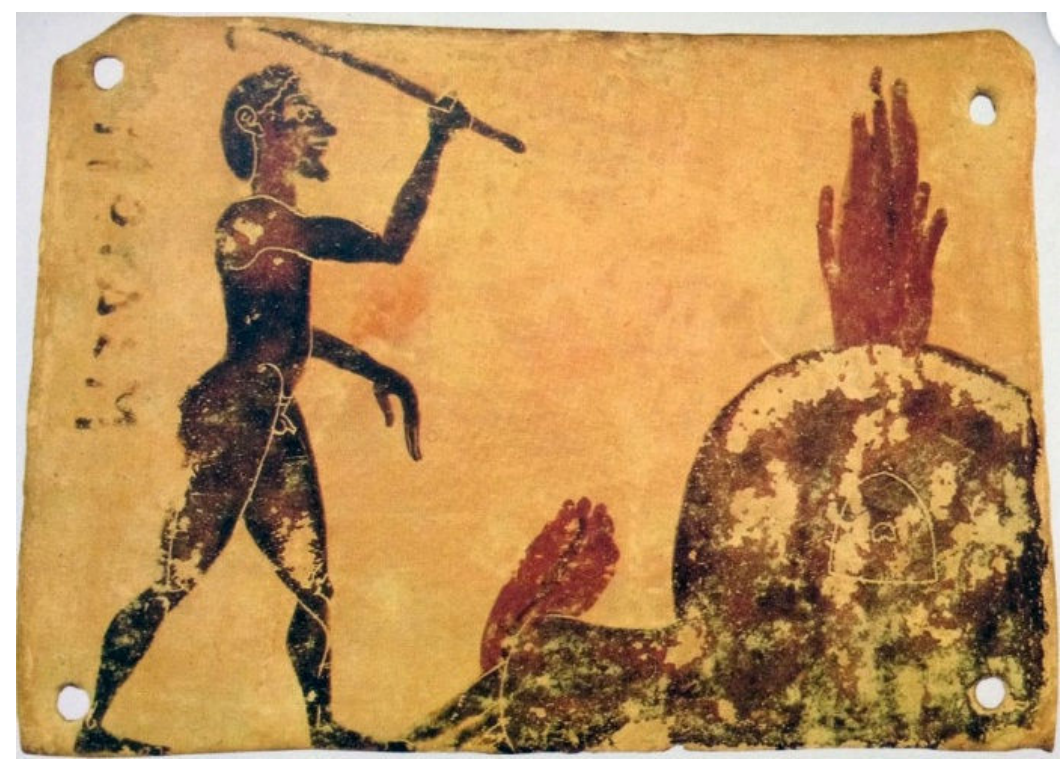

Fig. 22: Oleiro trabalha no forno. Placa votiva coríntia.

Os daimónes não estão inequivocamente representados na iconografia, mas aparecem claramente em textos que vão do final da idade do ferro, como um fragmento de Hesíodo, coros cômicos do período clássico, narrativas alexandrinas, como a Argonáutica de Apolônio de Rhodes, e helenísticas, como o De musica de Plutarco e Sobre a dança de Luciano (cf. Blakely, 2006, p. 14, n. 8). Nos relatos do século I a.C., os dáktyloi são relacionados ao ritmo dactílico da poesia épica e ao aulós, que teriam trazido à Grécia "para colocar ordem no ruído estridente das oficinas de bronze" (Blakely, 2006, p. 15). Mesmo considerando tais narrativas a-históricas, elas nos fornecem uma dimensão da penetração dessas figuras apotropaicas no mundo grego, desde que eles praticaram a arte metalúrgica. Os dáktyloi são os inventores dessa técnica, músicos e mágicos, famosos por sua dança e pela criação de feitiços, chamados letras de Éfeso.

O rico campo semântico dos dáktyloi é quase invisível devido à fragmentação das fontes e à sua dispersão por um largo período histórico. A dificuldade é perdoável, pois essas criaturas sugerem usos metafóricos da metalurgia que excede o que é visto em Hefestos, 
Cíclopes e outros artesãos míticos. De um ponto de vista da antropologia da tecnologia, sua amplitude e riqueza é exatamente o que se espera de materiais vitais economicamente e que são naturalmente objeto de elaboração metafórica. Quanto mais produtivo for um material, mais naturalmente elaborada é a sua posição na rede semântica de símbolo, mito e ritual. A qualidade complexa e lacunar dos dados gregos obscureceu a extensão da sua importância para o mundo grego; assim também os estilos de investigação, que se adequaram a modelos inspirados pelo nacionalismo, psicanálise, evolucionismo e primitivismo nos dados fragmentários, enxergando nos dáimones o modelo cultural apropriado para a própria época do estudioso (Blakely, 2006, p.2).

Os dáktyloi trazem no seu nome a ferramenta por excelência utilizada na performance dos artífices e dos músicos, os dedos. O termo aparece associado a um instrumento de cordas em particular, que seria uma variedade da kithára, o daktilíkon ou pýthikon. O instrumento pode ter sido tocado nos concursos píticos nos quais a música instrumental da kithára foi introduzida em 558 a.C. (cf. West, 2005, p. 59-60).

Os telchínes, tal como os dáktyloi, combinavam magia e metalurgia, mas do bronze. Eles tinham um aspecto farmacológico, relacionado à produção de venenos, e artístico, tendo forjado o tridente de Poseidon e o colar de Harmonia. Além disso, foram criadores de estátuas que pareciam respirar e se mover, similares aos assustadores autômatos de Hefesto. Eles eram os habitantes mitológicos da ilha de Rhodes, chamada de Telchines, e foram considerados malditos por terem se vingado dos habitantes da ilha "derramando as águas do Styx para fora nos campos para torná-los inférteis" (Blakely, 2006, p. 15). Na mitologia grega, Styx é o rio que fica na fronteira entre a Terra e o Hades. Blakely, referindo-se à deformidade de Hefesto, diz que "o arsênico que era usado em bronzes arsênicos podia envenenar o ferreiro e resultar em deformação dos membros" (2006, p. 32-3), o 
que está retratado na figura de Hefestos. Sabe-se que por volta de 3000 a.C. o bronze passou a ser produzido a partir de uma liga de cobre e estanho, pois antes só havia o bronze arsênico. Assim, é possível supor também que a ilha de Rhodes tenha sofrido uma espécie de desastre ambiental causado pelo clã dos telchínes que assim passaram a ser considerados malditos. Nesse caso, o caráter lendário pode ter tido uma dimensão histórica. Como diz Blakely: "é perigoso olhar para correlações do mito na história, mas talvez pior é falhar em fazê-lo" (2006, p. 202).

O domínio do processo de fabricação do bronze pelos telchínes estabelecia uma conexão direta com os fabricantes de instrumentos musicais, pois dentre as qualidades do bronze está a sonora e o metal era utilziado na fabricação de instrumentos como as krótala e a sálpinx.

O valor do ferro e do bronze subentendia a técnica de produzilo, muito mais complexa que a do ouro, da prata e do cobre. A produção do ferro especialmente implicava em manipulação de temperaturas altíssimas. Isso colocava os detentores dessa técnica numa alta posição social e a posse desse segredo estimulava a competição das elites guerreiras, que costumavam fazer oferendas em santuários e concursos como demonstração de poder. Nesse aspecto, é interessante observar que uma sobreposição dos locais em que se desenrolam as atividades lendárias desses dáimones com os centros tradicionais de artesanato. O costume de oferecer prêmios ou oferendas de metal ricamente trabalhados era admirado pelos gregos. Isso fez com que se desenvolvessem oficinas de diversos materiais nos lugares onde ocorriam os jogos sagrados, como em Olímpia. A cidade de Argos, conhecida por sua produção em metal estabeleceu em Olímpia uma oficina própria para a criação de artefatos votivos como as famosas trípodas (cf. Blakely, 2006, p. 205). 


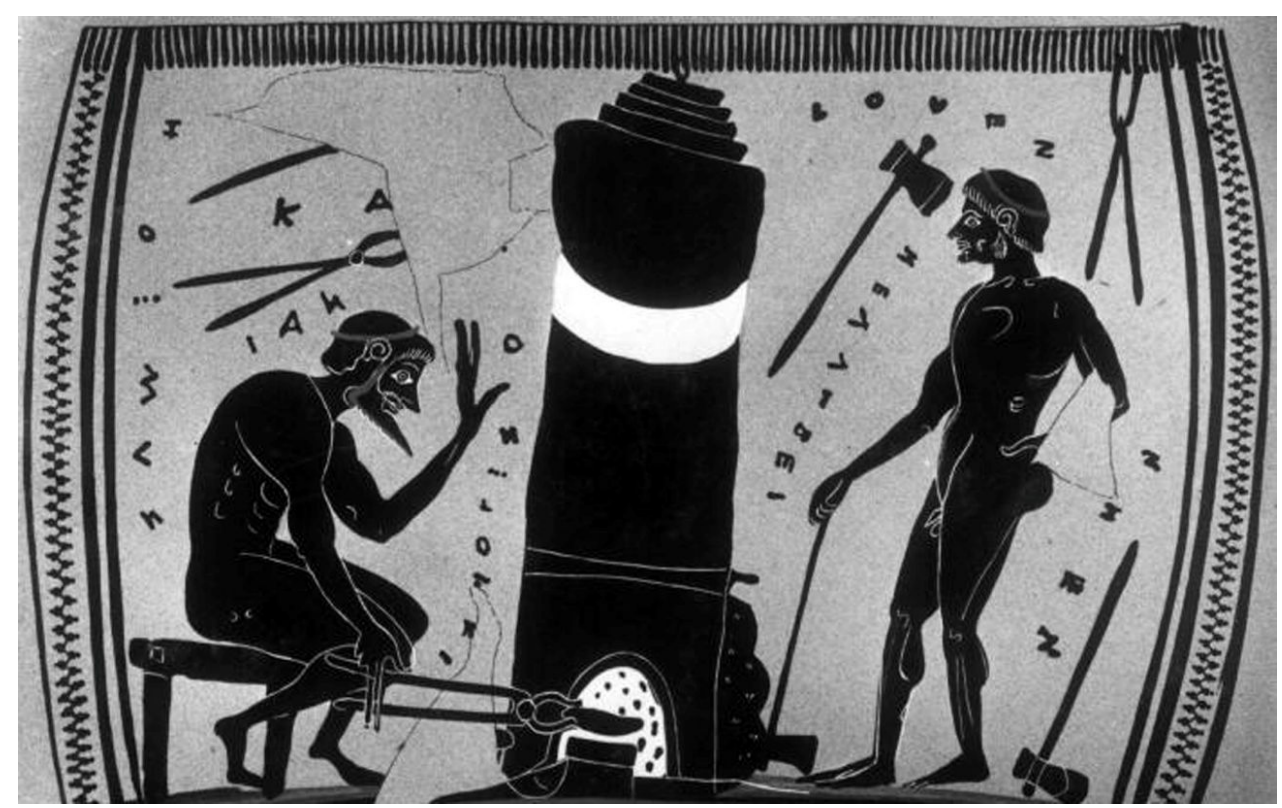

Fig. 23: Metalúrgicos alimentam fornalha em detalhe de jarro com bocal para servir vinho. Cerâmica ateniense, encontrada na Itália, c.550-500 a.C.

Os dáimones também protegiam as cidades e sua função muitas vezes se justapunha à dos deuses e heróis. Apesar do temor que inspiravam, sua inserção popular revela o aspecto do cotidiano dos artesãos, que temiam queimaduras nos fornos ou terem suas peças danificadas. A compreensão do papel dos dáimones metalúrgicos amplia o conhecimento que temos da cultura popular grega, podendo esclarecer aspectos dos textos consagrados. Como diz Blakely: "As fontes de informação a respeito dos dáimones coloca seu valor como uma ferramenta conceitual não apenas entre os ferreiros em si, mas com uma matriz mais ampla da sociedade grega" (2006, p.23).

Na acepção atual, a magia é tida como a habilidade de produzir efeitos extraordinários, também chamados de sobrenaturais. Segundo Heródoto, 10 os magos medas eram chamados a interpretar sonhos e oficiar cultos e disputaram o poder com o rei persa Cambises (529-522 a.C.) chegando a usurpar seu trono, sendo em seguida massacrados (1985, p.169-171). No período clássico, o termo foi usado pejorativamente "em associação com termos como charlatão ou

10 "As tribos dos medas são as seguintes: os busos, os paretacenos, os estrúcatos, os arizantos, os búdios e os magos" (Heródoto, 1985, p. 53). 
vagabundo" (Lloyd, 1979, n. 20, p. 13). Mas Platão (427-347 a.C.) utiliza o termo magueutiké como uma téchne relacionada a produção de fármacos, mais especificamente, antídotos (cf. 280e). ${ }^{11}$

O campo semântico da raiz indo-europeia |mag está associado a ideias de amassar, cozinhar, modelar, ligando-se a termos técnicos terapêuticos, metalúrgicos e alimentares. Uma das acepções de mágos

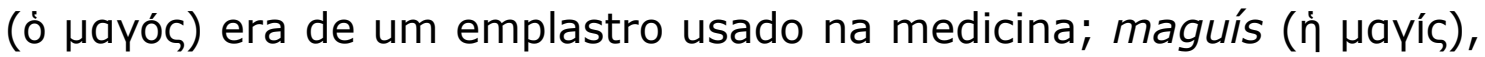

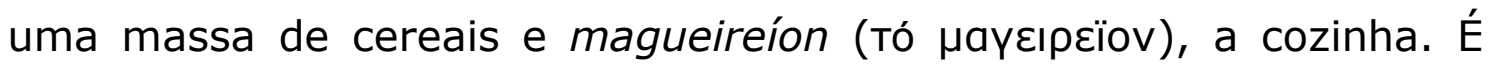
possível considerar que, na Antiguidade grega, o termo magia esteve associado tanto às práticas dos magos e seus sortilégios mágueumas - quanto a formas de trabalhar elementos da natureza para tirar dela qualidades específicas. Assim, os dáimones podem nos dar pistas das ligações entre as técnicas mágicas e a filosofia natural. Para Kingsley: "A magia está ligada à ciência do mesmo modo que está ligada à tecnologia. Não é apenas uma arte prática, é também um armazém de ideias" (apud Blakely, p. 2006, p. 212).

Tomlinson chama a atenção para as sobreposições de significados entre música e magia em termos como "encantamento" e "encantar" e expressões como a "magia da música". Nessa noção está impressa a ideia de uma manipulação de forças naturais - ou sobrenaturais - a fim de produzir um efeito desejado. Na música, os tons - uma força natural e invisível - são manipulados a fim de produzir efeitos desejados, mas de expressão (cf. Tomlinson, 1993, p. 1). Mas a noção de sobrenatural, no entanto, só se desenvolve quando sobrevém a ideia de natureza como princípio universal. Ela foi construída a partir da experiência imediata, comum, dos fenômenos da natureza, como chama a atenção Lloyd, "a ideia de que todo fenômeno físico tem uma causa natural não aparecia como uma regra universal antes da filosofia" (1979, p. 51).

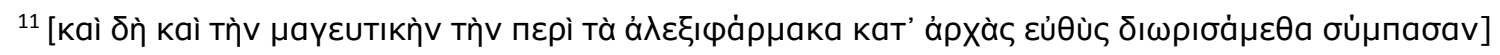


Na parte final da obra Os trabalhos e os dias, Hesíodo discorre em versos sobre a arte da navegação e da construção de navios. Elas compreendem observar os sinais das estações e a direção dos ventos para levar a outros lugares o produto de suas terras. Ele mesmo, Hesíodo, confessa não ter jamais embarcado no vasto mar:

Apenas fui a Eubeia, desde Áulis, onde outrora os gregos depois de esperarem o fim do temporal, juntaram tropas numerosas para irem da divina Hélade sobre Troia das belas mulheres. Daí, fiz travessia para Cálcis e para assistir aos jogos do valente Anfidamante; numerosos eram os prêmios propostos pelos filhos do magnânimo herói. E foi aí, bem o posso dizer, que um poema me deu a vitória, e de lá trouxe uma tripeça de duas ansas; dediquei-a às Musas de Hélicon, no próprio lugar em que elas me haviam inspirado o canto harmonioso. Eis, à justa, a experiência que tenho dos baixéis de numerosos pregos (vv. 654-690, p. 60).

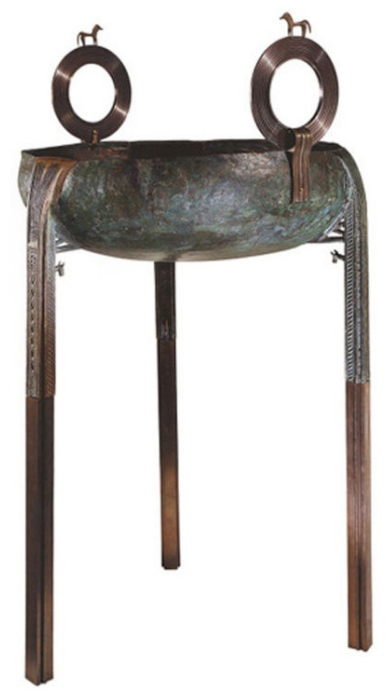

Fig.24: Trípoda ou tripeça. Caldeirão com três pernas e duas alças, de bronze, provavelmente feito em uma oficina em Corinto, restaurada, c. 750 a.C. Era comum a trípoda ser concedida como prêmio em competições. 


\subsection{Inovação no mito: a chélys-lyra}

No período arcaico há uma sobreposição das poesias épica e lírica. A transição entre os dois gêneros poéticos aparece nos chamados poemas homéricos, elaborados provavelmente por cantores profissionais como Hesíodo, que se apresentavam nos festivais e concursos dedicados aos deuses. Esses poemas anônimos foram criados por poetas líricos, que se dedicavam também à tradição épica, compondo poemas para serem apresentados nos festivais. Quanto mais rica a pólis que patrocinava o festival, mais ela reafirmava seu prestígio na comunidade helênica.

O fato dos hinos serem cantos direcionados aos deuses, leva alguns estudiosos a classificarem-nos como uma poesia sagrada ou ritualística. Mas o mito estava relacionado tanto com os rituais quanto com a vida cotidiana, estando presente em ambas as esferas.

No hino homérico dedicado a Hermes, é creditada ao deus a

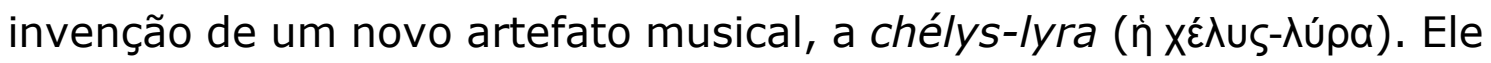
é ainda um recém-nascido quando inventa e constrói o instrumento para presentear a Apolo. O bebê prodígio pensa em distrair o deus para assim roubar seu gado, e tem a brilhante ideia ao topar casualmente com uma tartaruga:

Salve, amável beldade, cadência da dança, colega de festim (...)

Sim, de fato proteção contra os feitiços maléficos será em vida; mas se morresses, poderias cantar bem bonito (vv. 31-8).

O pequeno Hermes leva a tartaruga para casa e, como um artesão, cumpre todas as etapas de criação do instrumento. Ele abre e escava a tartaruga, com um buril de ferro, uma ferramenta de corte manual chamada glyphanos (ó y yúpavos), que podia ser de pedra ou de metal, e era utilizada para talhar, gravar, esculpir. Além de indicar a ferramenta, o poema dá um receituário tipo faça-você-mesmo para a construção desse novo modelo de lira, que utiliza elementos do 
mundo animal, como o casco da tartaruga para a caixa de ressonância, as tripas para as cordas, e do vegetal, como a espécie arundo donax para os braços da lira:

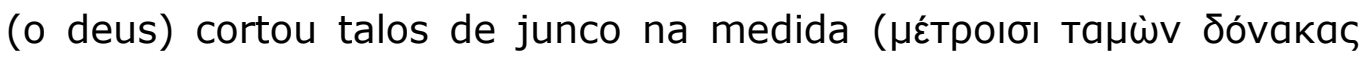

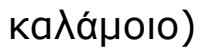

os fixou, prendendo suas extremidades atrás e através do casco da tartaruga.

Então esticou couro de boi em volta, com perícia.

E colocou dois braços e uma barra

em que esticou sete tripas de ovelha ressoantes.

Depois, tocou cada corda com o plectro, segurando o instrumento adorado.

Ao toque de suas mãos, ele soou maravilhosamente, e o deus cantou doces melodias de improviso (vv. 47-55).

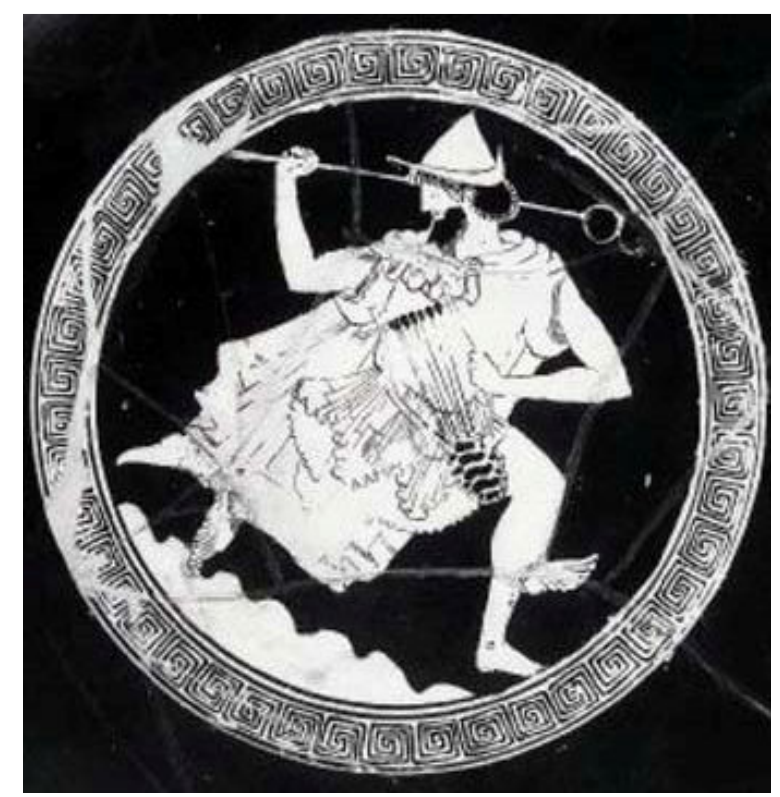

Fig.25: Hermes com o caduceu na mão direita e a chélys-lyra na esquerda.

Hermes encontra casualmente a tartaruga e em seguida canta melodias que ele mesmo criou, aủTooxeסíns (v.55). Há uma ideia de ausência de esforço, e essa nobre "facilidade" divina fica evidente no fato de que Hermes é ainda um bebê quando "inventa" a chélys-lyra. 
Quando ele presenteia Apolo com o instrumento, o Arqueiro imediatamente começa a tocá-la.

A beleza e a eficácia do hino estão na descrição das ações específicas do um artífice: cozinhar, furar, escavar, atividades tipicamente humanas. Mas o deus não precisa aprender nenhuma das artes e, se as pratica, o faz por prazer. No hino a Hermes, a téchne é apresentada como um bem-humorado deleite aristocrático.

Mas a criação desse artefato tinha o claro objetivo de enganar Apolo e assim roubar seu gado, pois o bebê quer comer churrasco. $O$ plano dá certo, e para cozinhar as carnes, Hermes torna-se um novo Prometeu, criando a técnica de produção e preservação do fogo.

Ele (Hermes) juntou uma pilha de madeira

e começou a experimentar a técnica do fogo.

Pegou um esplêndido galho de louro e o fez girar

em um ramo de melograno o mantendo firme entre as mãos

e uma fumaça quente surgiu.

$\mathrm{Na}$ verdade, Hermes foi o primeiro a revelar o fogo e os instrumentos para acendê-lo.

Depois, recolheu bastante lenha seca e dura

e em um fosso escavado no chão a colocou em abundância

e lampejou a chama, difundindo a luz do fogo, que ardia intensamente (vv. 108-114).

Há distinções claras com o Prometeu hesiódico. Nada do que Hermes faz implica luta, embate ou trabalho penoso. Ao inventar a técnica de preservação do fogo, o deus não o faz por alguma necessidade de se alimentar, apenas por um desejo.

A leveza e a comicidade do poema estão em sintonia com a popularidade que alcançou a chélys-lyra na Grécia, tornando-se o instrumento musical da paideia grega. Em contraste com a monóxila phórminx, escavada num bloco único de madeira, a chélys representa uma forma de construção inovadora: a assemblage. 


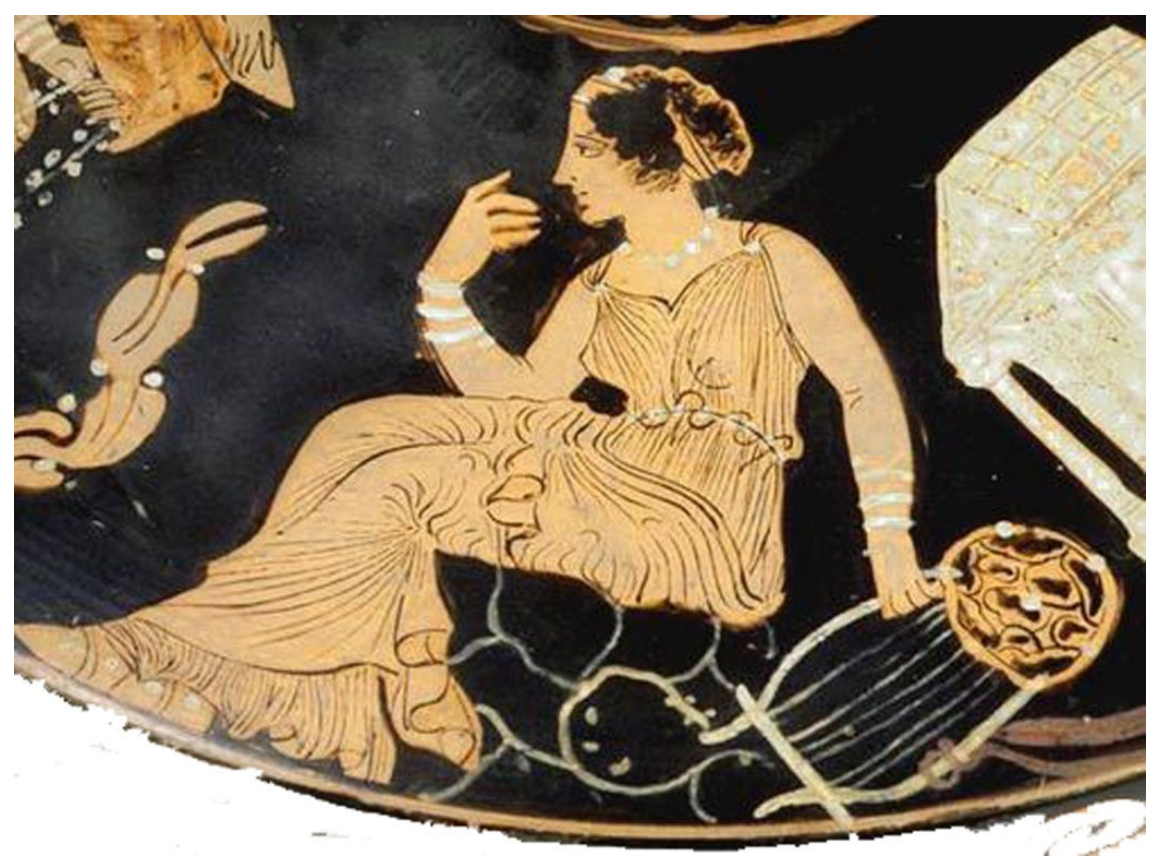

Fig. 26: Musa com a chélys-lira. Vaso em forma de bacia, c. IV a.C. 


\section{Capítulo 3 -ARTEFATOS E ARTÍFICES}

\subsection{A conjunção de técnicas na fabricação da kithára}

O período arcaico foi de intensas transformações que afetaram e foram afetadas pelo quadro técnico grego que, para os helenos, era a marca de sua civilização. Nesse contexto, é de se esperar que a música e a poesia sejam cada vez mais elaboradas. No período arcaico, elas estavam ligadas tanto ao gênero épico dos hinos homéricos, quanto à nova poesia lírica, feita por poetas como Arquíloco de Paros, Alcmán, Safo e Alceu de Lesbos, que surgem no século VII a.C. Não há, ao menos até hoje, fonte primária textual dessa arte literária do período arcaico grego, só referências posteriores em fragmentos, mas sabe-se que a poesia era cantada com o acompanhamento de instrumentos musicais, especialmente a lyra, que emerge com essa nova forma de expressão e parece mesemo ter se tornado um símbolo da inovação técnica.

Na última metade do século VII, a cidade de Esparta tinha uma forte expressão cultural. Lá viveu Alcmán, que compôs poesia coral para ser cantada por moças e alguns escritos sugerem que ele mesmo tocava a parte de lyra. Em seus poemas está enunciado o desejo de mudança do status social do poeta e do músico, comparando-o ao guerreiro: "o bom tocar da lyra compete com armas de ferro" (apud Maas e Snyder, 1987, p. 31),

Apesar da importância do canto na cultura grega, menos se pode inferir da música vocal do que da instrumental a partir da iconografia. Como diz Vergara

Apesar de haver uma série de signos que identificam a prática do canto (como boca aberta, cabeça inclinada para trás, texto saindo da boca descrevendo uma trajetória circular), muitas vezes não se pode ter certeza se o personagem está cantando ou recitando um poema ou simplesmente falando, diferentemente do instrumento musical, que 
nos remete com certeza à música instrumental, mesmo quando representado como um atributo suspenso no campo. Tomar a boca aberta de um personagem como base para um estudo sistemático do canto seria confiar demais no detalhe do desenho da anatomia. Por outro lado, a identificação de um instrumento musical numa cena é um fato que não deixa margens a incertezas (2001, p. 3).

Em contraste, os instrumentos musicais e suas formas de execução são bastante nítidos em um grupo enorme de cerâmicas, relevos e esculturas. Em uma representação da cena do combate entre Teseu e o Minotauro, um músico carrega uma chélys-lyra, com a palavra lyra escrita a seu lado (Fig. 27).

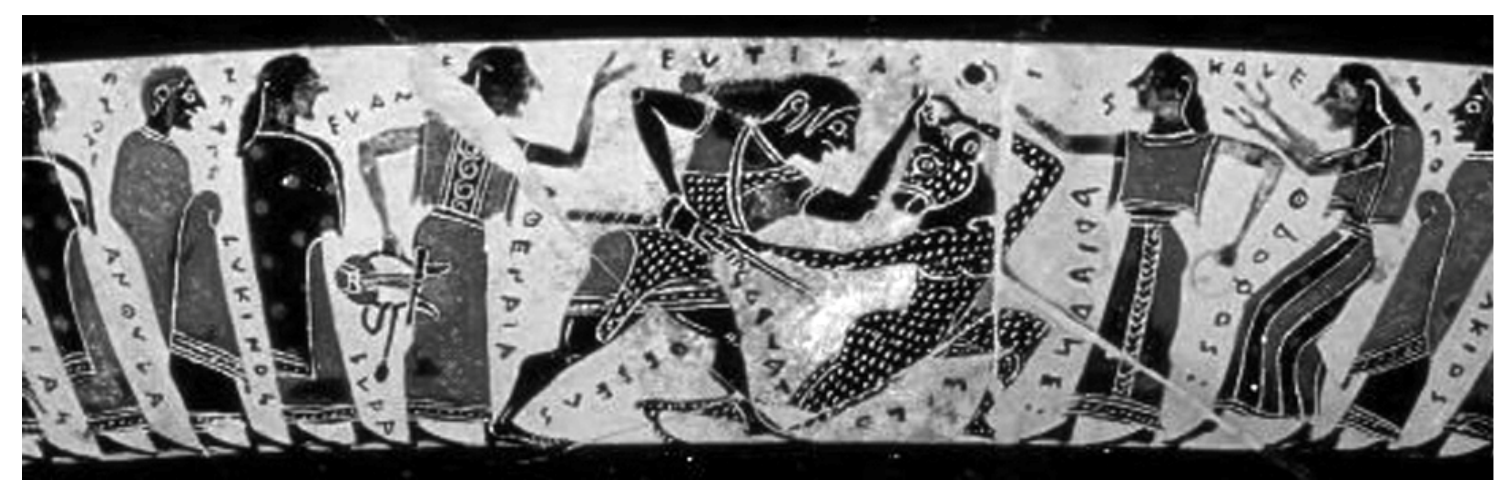

Fig.27: Teseu lutando contra o Minotauro. À esquerda, uma figura feminina segura uma chélys-lyra, com a palavra lyra escrita abaixo do plectro, que está pendurado.

A presença do termo escrito reforça a importância do objeto, mas também do próprio alfabeto, que aparece nos vasos como uma demonstração do domínio da sua técnica pelo pintor ou ceramista. De acordo com Havelock, a escrita alfabética foi de início um território dos comerciantes e artesãos.

Os inventores, e por muito tempo os únicos usuários habituais do alfabeto, foram artífices e comerciantes. Sem dúvida, com o passar do 
tempo, as classes ociosas travaram algum conhecimento com as letras, mas a extensão em que o fizeram continua problemática, pois eles tinham motivos reduzidos para empregar esta arte, até as décadas intermédias do século $V$. Os filhos dos artífices iam trabalhar nas suas oficinas antes da puberdade e, se aprendiam a usar a letras, era lá que o faziam. O garoto da classe alta, cuja educação se prolongava até a adolescência, tinha tempo para instruir-se nas artes superiores, que não incluíam a leitura. Há indicações de que na época de Pisístrato, e posteriormente, era comum um domínio elementar da escrita e da leitura entre os artesãos. (1996, p. 191)

Tal como a assinatura do artífice Euthykartides, que comentamos, a lyra surge nesse momento em que há uma valorização da subjetividade, traço característico também da poesia lírica. A lira era instrumento com uma sonoridade menos brilhante que a phórminx, mais adequada a uma música de câmara. Cntudo, a terminologia dos instrumentos de início não é precisa. Os poetas usam alternadamente lyra e phórminx para o instrumento que eles mesmos tocavam e que muito provavelmente não era uma chélys-lyra, mas um instrumento de qualidade superior.

Além da presença nos poemas épicos e líricos e das marcas iconográficas, sobreviveram vestígios arqueológicos desse período arcaico de modo que instrumentos musicais reais (mesmo que danificados) contribuem para a investigação.

A phórminx de sete cordas segue aparecendo na iconografia até o final do século VI a.C., quando já existem representações claras da chélys e da kithára. Uma ânfora da ilha de Mélos, da segunda metade do século VII a.C., mostra um instrumento que parece ser da última geração da phórminx (Fig.28). 


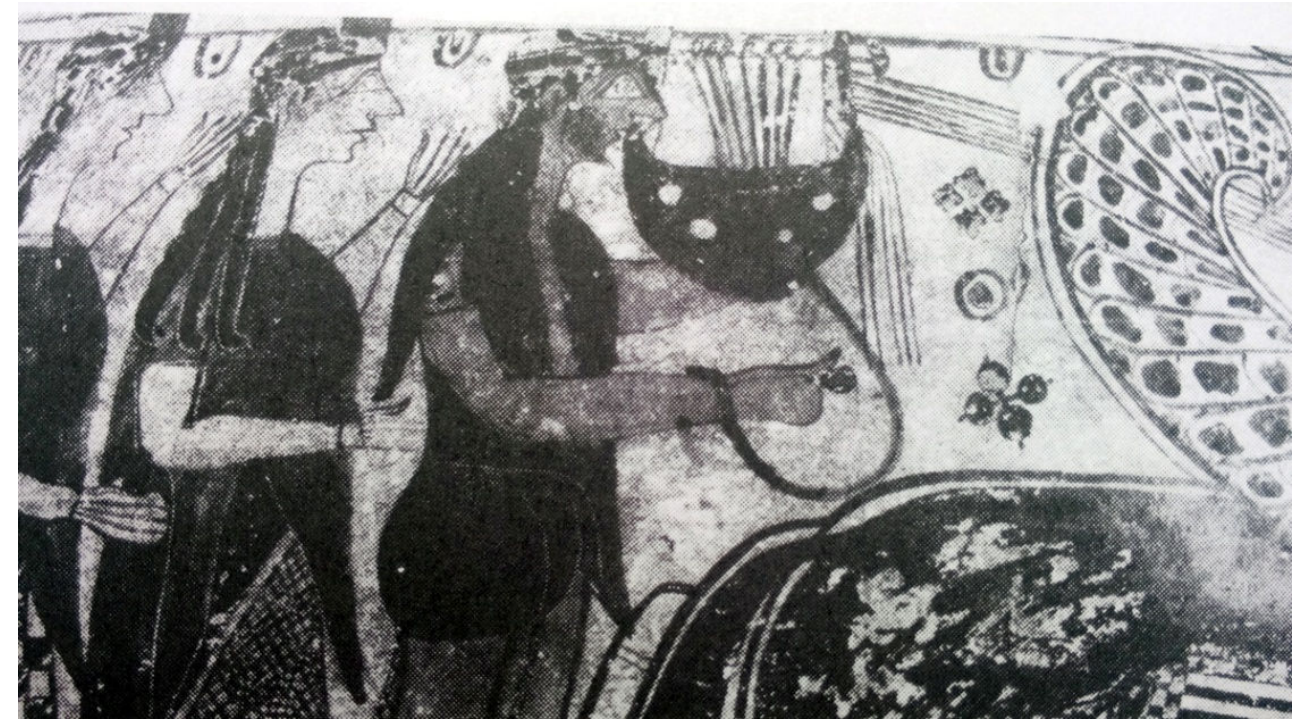

Fig. 28: Detalhe de Ânfora de Mélos. Músico acompanhado de mulheres em um cavalo alado.

O músico carrega o instrumento numa posição de destaque, à frente da carruagem, levando alguns estudiosos a considerarem que esta seja uma representação de Apolo com as Musas. ${ }^{12}$ Quer seja ou não Apolo, é possível observar perfeitamente a caixa de ressonância de base curva e o plectro preso nela por um cordão. Surgem orifícios na caixa de ressonância, que, como vimos, havia aumentado.

Outra imagem interessante foi encontrada em uma apoikía na costa da Anatólia e que mostra claramente as sete cordas, a base redonda e as manivelas (ou ornamentos) laterais (Fig. 29).

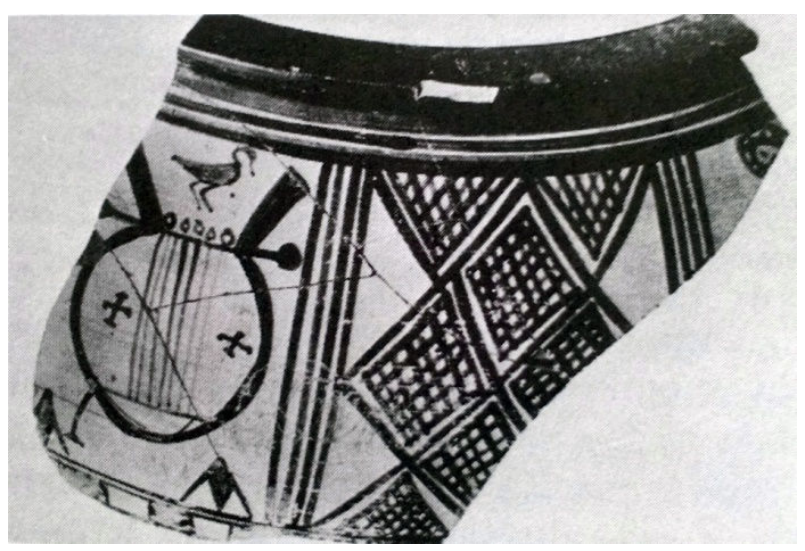

\footnotetext{
${ }^{12}$ Maas e Snyder observam uma caraterística curiosa da imagem: "Apolo não segura as rédeas dos cavalos, elas estão presas no braço externo do instrumento" (1989, p. 28).
} 
Fig. 29: Lira de base curva e braços curvos, com sete cordas. Smyrna, costa da Anatólia, segunda metade do século VII a.C.

Algumas dúvidas surgem a respeito dos braços curvos do instrumento mostrado na imagem acima, eles se parecem com os da chélys, mas o instrumento é feito com peça única. Na medida em que a morfologia de um instrumento modifica a sua sonoridade, é possível que a presença do epíteto glaphýre - associado à phórminx -marque a característica da sua caixa de ressonância: escavada e curva. E sua qualidade sonora, clara, ligýs, se acentua pelo fato de suas cordas serem tangidas com o plectro. A barra superior, o zygón, prende as outras extremidades das cordas, por meio dos pequenos anéis de couro enrolados, os kollópes. Em cada ponta do zygón, estão presos espécie de discos que podem indicar que seria possível girar a barra para afinar as cordas, contudo, segundo Maas e Snyder,

considerando as diferenças nas tensões requeridas conclui-se que essas manivelas, que em algumas formas da lira raramente aparecem, parecem ter sido ornamentais em vez de funcionais (1989, p. 28).

Essa distinção entre o ornamental e o funcional, nos parece, no entanto, deslocada. A phórminx possuía cordas de comprimento igual, fazendo com que a afinação entre as cordas dependesse de sua espessura e tensão. Um elemento dos instrumentos da família dos violinos atuais pode auxiliar na compreensão da função dessas discos ou manivelas laterais. No violino, as cordas são enroladas e tensionadas primeiro nas cravelhas e depois a afinação mais fina é feita por meio de pequenos controles no estandarte, chamados de afinadores. É possível que os kollópes e os pequenos pedaços de madeira, que aparecem enfiados nela em algumas representações, atuassem com esse princípio similar aos afinadores. Se assim for, os discos teriam a função primeira de apenas ajudar a enrolar as cordas no zygón, tal como as cravelhas no violino, para que depois fossem 
afinadas nos kollópes, sendo assim não apenas ornamentais. Duschesnes e Guillemin, que analisaram instrumentos gregos e orientais também se manifestaram a respeito dos discos laterais do zygón dizendo que os gregos são funcionais, além de ornamentais: "Entre o procedimento asiático e o grego, há toda a distância que separa um ajuste qualquer de um dispositivo particular, calculado para desempenhar uma função" (1935, p. 123).

Na figura 30, é importante observar a posição de performance do músico, segurando o plectro, preso em seu punho, com a mão direita. O instrumento está distante do corpo, o que nos leva a imaginar, se a representação for precisa, que ele é leve, esculpido em uma madeira macia. A mesma posição pode ser observada no instrumento abaixo, que além disso tem um cavalete e um estandarte prendendo as cordas na parte inferior da caixa (Fig. 30).

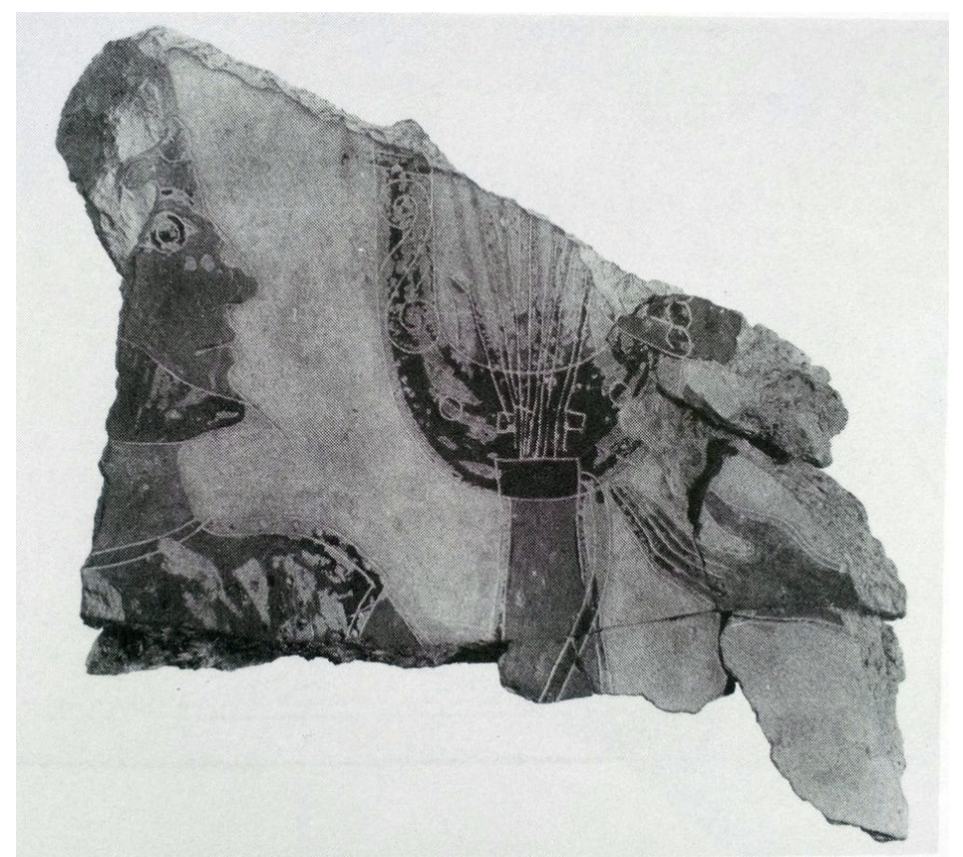

Fig. 30: Fragmento de uma placa votiva com homem tocando instrumento de base curva, com orifícios na caixa de ressonância, cavalete e ornamentações nos braços.

A associação da phórminx com Apolo e as musas remonta ao século VIII. No início da era arcaica, no hino homérico a Apolo, o deus toca a phórminx com um plectro de ouro. 
Traz a phórminx o filho de Leto gloriosa

Com vestes imortais e perfumadas

Avança tocando a curva phórminx.

Com seu plectro de ouro a phórminx soa adocicada (vv. 182185, p. 147).

A chélys-lyra talvez seja a inovação instrumental mais importante do período arcaico. Ela já começa a aparecer em cerâmicas do final do século VIII e início do VII a.C. Em escavações do templo de Ártemis em Esparta foram encontrados seis pequenos objetos votivos que são miniaturas de chumbo da chélys e de seus performers. O objeto representando a chélys possui pequenos bastões na parte superior provavelmente para aprimorar a afinação das cordas.
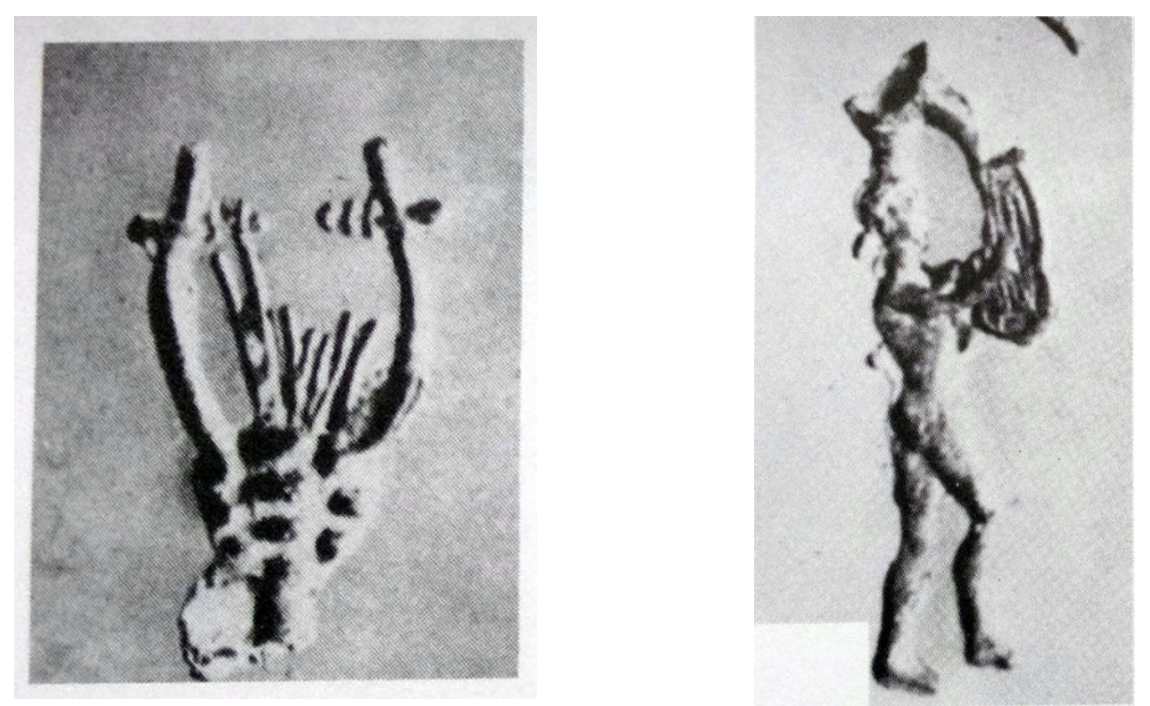

Fig. 31: Objetos votivos de chumbo encontrados no templo de Ártemis Órthia em Esparta, c. VII a.C.

Em 1985, Colin Renfrew apresentou vestígios arqueológicos do santuário de Phylakoni, na ilha de Mélos, de 1300-1100 a.C. Eles consistem em quatro fragmentos de carapaças de tartaruga com 
orifícios cuidadosamente perfurados. ${ }^{13}$ As evidências levaram Renfrew a considerar que os fragmentos fossem de fato de uma chélys-lyra, pois carapaças de tartaruga perfuradas dificilmente teriam outra função a não ser servir de caixas de ressonância de instrumentos. West argumentou que elas poderiam ser de outro instrumento, da família dos alaúdes (1992, p. 57 n. 38). Mas em outro lugar, o próprio autor diz que os alaúdes só aparecem no mundo egeu no século IV a.C. (1992, p. 79), fato reconhecido por outros musicólogos. As carapaças de Phylakoni foram analisadas por Creese.

Fica claro nos exemplos completos do período arcaico usados em liras, que os orifícios eram perfurados com três propósitos distintos: orifícios perfurados no alto da parte convexa superior das carapaças propiciavam a fixação interior dos braços do instrumento; nove orifícios perfurados nos escudos marginais (ao longo do perímetro da carapaça) em intervalos regulares de, a cada $2 \mathrm{~cm}$ aproximadamente, permitiam esticar a pele sobre a abertura da carapaça; dois furos ligeiramente maiores auxiliavam a fixação de um estandarte na parte inferior final da caixa de ressonância (1997, p. 54).

Essas carapaças datam do período em que a ilha de Mélos estava sob o domínio micênico na idade do bronze, o que levou Creese a considerar uma origem não egípcia e não africana para a chélys-lyra. Existem instrumentos africanos com princípios de construção muito parecidos com a chélys, inclusive utilizando a carapaça de tartaruga como caixa de ressonância, mas o autor demonstra que estes são posteriores (1997, p.70-77). Assim, Creese propõe uma origem propriamente grega para o instrumento, um pouco anterior à era arcaica, deixando em aberto se ela é micênica, minoica ou trácia, algo que seria difícil de validar.

13 Renfrew, Colin. Archaeology of $\mathrm{C}$ u I t: The Sanctuarv at Phvlakoni (London: Thames and Hudson, 1985 (In: Creese, 1997, p. 50, n. 5). 
No Hino a Hermes foi possível conhecer com precisão os materiais utilizados na caixa de ressonância, além do casco da tartaruga e o couro de boi. Entre os termos técnicos nomeados, está o primeiro registro de pechys (ó пñxuৎ), para os braços laterais e zygón, para a barra ou travessão superior e que já havia aparecido anteriormente na epopeia homérica. Como vimos, no hino, o deus tem muita facilidade na sua confecção. De fato, se compararmos a chélys aos instrumentos profissionais como a phórminx, e mais tarde a kithára, parece simples colocar todos os elementos repertoriados por Hermes na sua confecção.

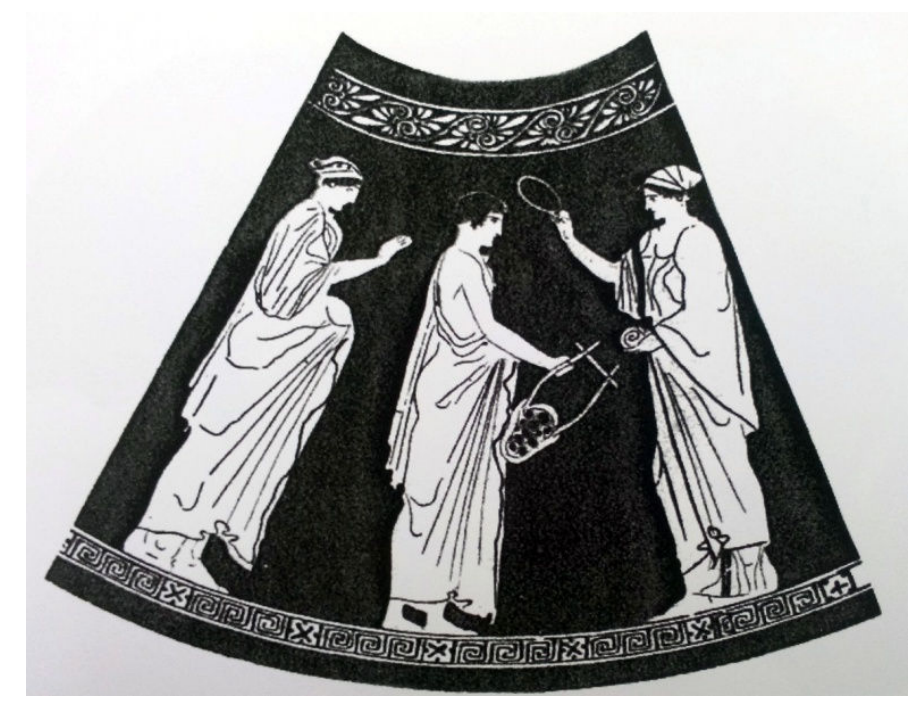

Fig. 32: Detalhe de vaso mostra um jovem segurando um instrumento que aparenta ser uma chélys. A cena é de um concurso, provavelmente no ambiente escolar pela vestimenta do jovem, no qual a chélys era mais utilizada, c. 440 a.c.

West comenta a respeito da chélys: "apesar de que posteriormente em Atenas e outros lugares elas eram moldadas por luthiers profissionais elas podiam em princípio ser feitas por qualquer um" (2005, p. 56-7). Contudo, não nos parece tão simples a confecção real do instrumento. Basta dizer que esse "qualquer um" teria de ser em primeiro lugar alguém disposto a, e capaz de, capturar uma testudo marginata, a tartaruga cuja carapaça era utilizada. Pausanias diz que as melhores espécies eram as que viviam na Argólida, mas estas "eram consideradas sagradas, dedicadas a Pan e cuidadosamente protegidas 
pelos locais" (apud West, 2005, p. 57, n. 34). ${ }^{14}$ Soa como uma advertência aos desavisados. De qualquer modo, devia haver fornecedores de carapaças de testudo no mercado, assim como de tipos específicos de madeira e de cordas.

O fato da chélys ser desmontável em partes simples, não significa que seria fácil montá-las num artefato cujo função ainda por cima é musical, ou seja, em que alguns conhecimentos de ressonância teriam de ser aplicados. O Prof. John Younger, da Duke University, nos Estados Unidos, que acompanhou a escavação dos fragmentos das carapaças de chélys-lyra no sítio de Mélos, descreveu "quão exatamente perfurados eram os orifícios" (apud Cresse, 1997, p. 54, n. 14). Assim, apesar da aparente simplicidade e facilidade, enfatizada pelo simbolismo do Hermes bebê, a construção de uma chélys-lyra passava pelo conhecimento de técnicas de caça, de botânica, de serraria, de escultura, de fixação das partes em couro, madeira, tripas, afora comportamento dos quelônios.

O material mais comum para os braços da chélys-lyra, a madeira, tinha de ser curvado simetricamente. De acordo com Teofrasto, a azinheira (Quercus ilex) era a espécie de madeira mais adequada à produção da barra (zygón) e dos braços (péchys), tanto de liras quanto de harpas (Hist. Pl. V 7.6, apud West, 2005, p. 57, n. 35). A azinheira, árvore nativa do Mediterrâneo e do norte da África, é de madeira dura e resistente, e costuma ser utilizada em embarcações, vigas, pilares, barris e cabos de ferramentas. Assim também a fabricação dos braços solicita uma madeira mais resistente.

O processo de recurvar a madeira era conhecido. Tratava-se de umedecer a madeira com vapor, o que permitia curvá-la. Em seguida, ela era colocada no molde desejado no qual permanecia até secar adquirindo o formato do molde, um processo ainda utilizado nos dias atuais. Os braços tinham de ser curvados para fora e depois para

${ }^{14}$ Creese diz que três espécies subtropicais do gênero testudo eram utilizadas: marginata (que sé aparece na Grécia), graeca e hermanni (1997, p. 77). 
dentro na parte superior, que era ligeiramente mais fina, imitando a forma de um chifre. Existem relatos de braços de lira feitos de fato de chifre e marfim, mas para Bélis, só nos períodos helenístico e romano é que eles aparecem.

Se todas as representações de liras, sem exceção alguma, mostram de maneira evidente que seus braços eram de madeira - sua forma não permite a dúvida - só podemos pensar em testemunhos tardios para afirmar que fossem feitos de chifre. Que eu tenha conhecimento, só Philostrato o afirma. Temos que admitir, então, que apenas em uma época tardia os músicos adaptaram chifres no lugar dos braços (Bélis, 1985, pp. 203-204).

Contudo, Heródoto relata que as armações das liras fenícias eram feitas de cornos de órix, uma espécie de antílope (1985, p. 253). Dada a simetria dos chifres desses animais, é bem possível que os fenícios o utilizassem e, os gregos, os importassem.

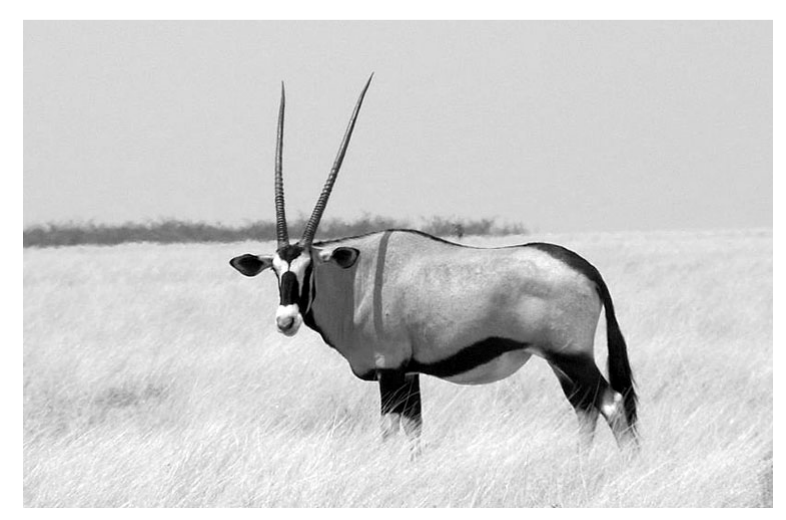

Fig.33: Fotografia de órix (Oryx gazella) africano. Observam-se os chifres retos, propícios à fixação das cordas em um instrumento.

Independente do material de que fossem feitos os braços, era necessário fixa-los à carapaça de tartaruga, e depois prender o travessão neles, sendo desejável que o conjunto apresentasse firmeza para que as tripas, chordé (í Xopঠ̀n), mantivessem a sua tensão, o que só seria alcançado completamente com os kollópes em torno do zygón. 
Assim, as partes requeridas para a fabricação da chélys-lyra eram de materiais bem distintos: caixa de ressonância, echeíon (Tò ńxعĩov) de tartaruga; braços (péchys) e travessão (zygón) de madeira (ou chifres,

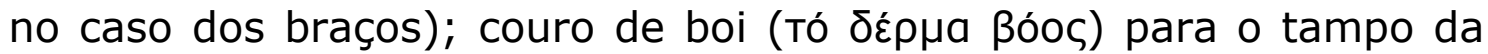
caixa e dispositivos de couro para afinação (kollóps); tripas de carneiro ou de ovelha para as cordas; madeira novamente, quiçá de outra

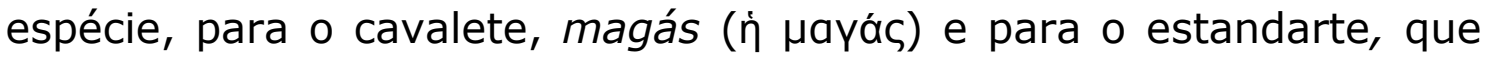
podia ser feito de metal; por fim, o pedaço de taquara (dónakas kalámoio), cuja função não está muito clara, mas possivelmente fosse colocado no interior da carapaça de tartaruga para auxiliar a fixação do couro. É pouco provável que ele tivesse a função de uma alma, dispositivo presente no interior dos instrumentos de arco e que serve para suportar a pressão das cordas, permitindo assim que os tampos sejam mais finos. Landels comenta a respeito de uma expressão que aparece em uma peça teatral de Sófocles: "tirar a taquara da lira de alguém", que corresponderia a algo como "puxar o tapete", ou seja, tirar o reforço da estrutura do instrumento (cf. Landels, 2000, p. 64), mas dada a espessura das carapaças parece que a função é bem distinta da alma dos instrumentos de arco.

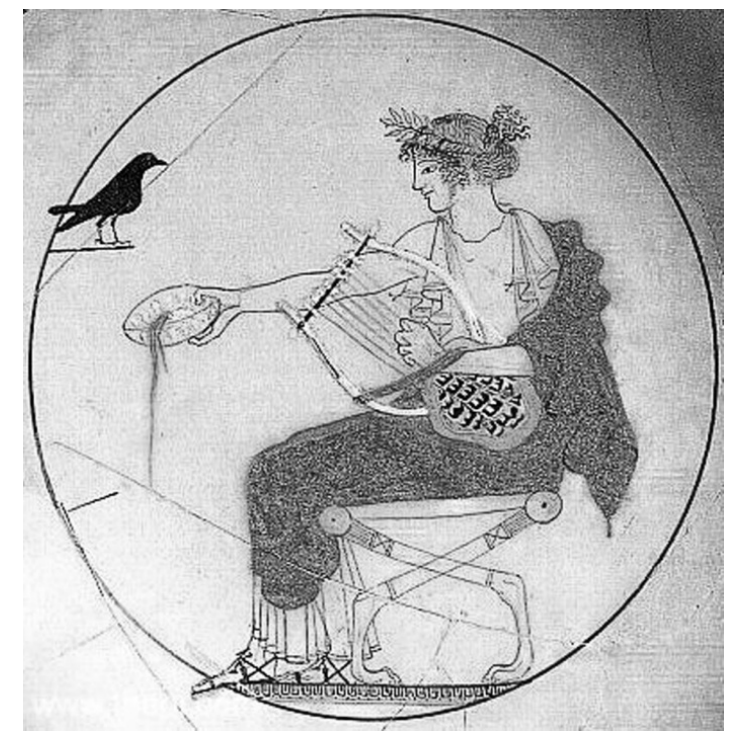

Fig.34: Detalhe de uma taça aberta com alças para beber vinho, c. 480-470 a.C. Apolo verte uma libação com a mão direita e, com a esquerda, segura o plectro, mantendo a lira presa ao punho. 
Além das caixas de ressonância de tartaruga encontradas em Phylakoni, outros sítios arqueológicos menos antigos apresentaram carapaças com orifícios perfurados em disposições ao seu redor, provavelmente para fixar a pele na caixa (e talvez o pedaço de taquara em seu interior). Nos buracos superiores deixados pelas pernas da tartaruga eram introduzidos e fixados os braços.

A iconografia não permite precisar como era feita a junção dos braços, péchys, com o travessão, zygón, mas devia ser um encaixe bem firme, talvez fixado com cordas e ainda colado, uma vez que ele tinha de segurar as cordas tensionadas do instrumento. O zygón tinha de permanecer imóvel para permitir que os kollópes enrolados em seu redor mantivessem afinadas de maneira estável as cordas do instrumento. Creese apresenta uma reprodução de um sistema de afinação da kissar sudanesa atual que é similar ao antigo kóllops grego (Creese, 1997, fig. 24, p. 98).

As cordas da lira tinham o mesmo comprimento e na sua produção vários pedaços de nervos ou tripas eram torcidos, criando uma variação na sua espessura pois as variações tonais advinham das diferenças da tensão e densidade, e não do comprimento da corda.

Em nenhum dos vestígios arqueológicos foram encontrados fragmentos de cavaletes, mágas, mas a partir da iconografia e da função percebidas em instrumentos até hoje, inferimos que ele era uma peça de madeira, fixado na caixa de ressonância de modo a sustentar as cordas. Ao mesmo tempo, devia transmitir a vibração para o interior da caixa, tendo uma presença importante na construção do timbre do instrumento. Certamente os artífices sabiam que a fixação do mágas não podia ser feita com cola e que ele deveria se manter preso apenas pela pressão das cordas na caixa de ressonância do mesmo modo que os violinos atuais.

O dispositivo que prendia as cordas na parte inferior era o estandarte chordotónos (ó хорботóvoc). De acordo com Anderson, só temos notícia do termo chordotonon no período "pós-helênico" (1994, 
p.174) ${ }^{15}$ mas como pudemos observar na figura 28 , ele já estava presente na phórminx. Segundo Creese, foi encontrado também um estandarte em um fragmento preservado de uma carapaça de lira encontrada no sítio de Arta, no noroeste da Grécia (1997, p. 101, n. 42). ${ }^{16}$

A última etapa descrita no Hino a Hermes é a colocação da taquara no interior da chélys, cuidadosamente, na medida ( $\left.\mu \varepsilon \dot{T} \rho \circ \sigma^{\prime}\right)$, reforçando a ideia de que as diferentes etapas de corte, fixação, moldagem e colagem exigiam um conhecimento técnico minucioso.

A chélys-lyra irá se tornar um dos instrumentos mais populares do período clássico. A sua inserção no poema homérico dentro do gênero do prótos euréte da literatura grega, reforça a ideia de que os gregos consideravam-se seus inventores.

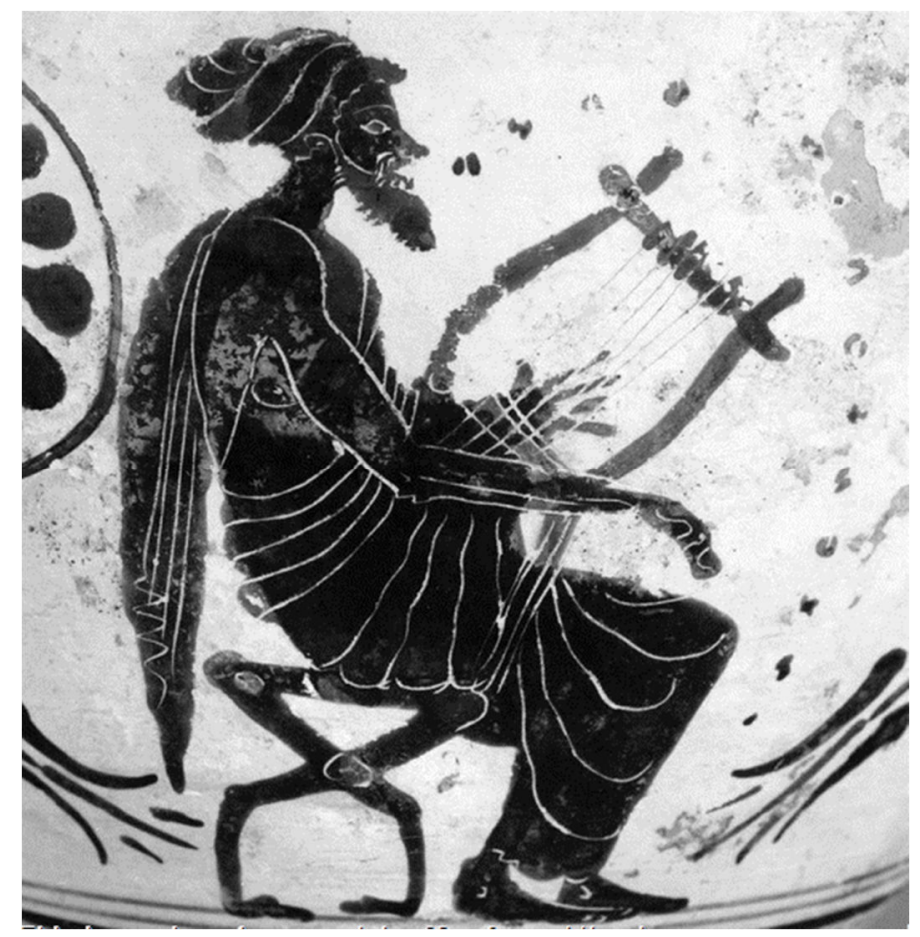

Fig. 35: Detalhe de um vaso alto com dois pés para se tomar vinho. Homem canta e toca a chélys com o plectro na mão direita, enquanto a esquerda abafa as cordas, c. 525-475 a.C.

${ }^{15}$ Nicômaco de Gerasa (séc. II d.C.) atribui a denominação chordotonon à Pitágoras no sexto capítulo da Encheiridion harmonikes (1994, p. 85), capítulo dedicado à questão dos pesos que Pitágoras teria preso às cordas, para demonstrar a relação entre peso e tensão. 0 termo aparece ainda em Ateneu (637d).

${ }_{16}$ Ver desenho do estandarte em Creese, 1997, p. 102, fig. 25. 
A fantástica miniatura de engenharia que é a chélys será reproduzida em outra escala no bárbitos (ì ou ò ßápßıтoৎ), instrumento que possuía o mesmo casco de tartaruga como caixa de ressonância, mas tinha braços e cordas mais longas e, portanto, uma tessitura mais grave e uma afinação menos tensa.

O bárbitos é mencionado pelo poeta lírico Anacreonte e costuma ser considerado, portanto, sua invenção; Safo e Alceu o chamam de bármos. De acordo com Maas e Snyder, antes de 525 a.C., o instrumento era "virtualmente desconhecido na Grécia continental" (1989, p. 39). Ele surge na arte ática entre o final do VI e metade do $V$ a.C., e depois desaparece. West cita um fragmento de uma comédia de Anaxilas em que uma das personagens é um construtor de instrumentos que fala em dórico e que ainda tem barbitoi para vender (apud West, 2005, p. 58). No tempo de Aristóteles, ele era considerado um instrumento "dos antigos" (1341a 39).

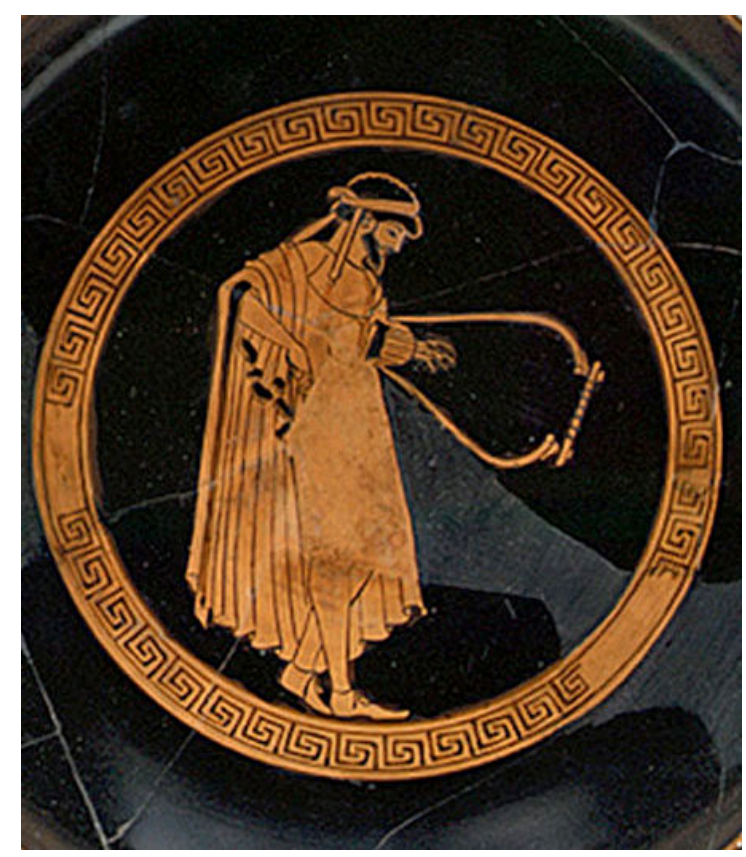

Fig. 36: Fundo de vaso mostrando bárbitos. 
Na Figura 37 vemos um braço de instrumento com o músico tensionando as cordas no zygón do que parece ser um bárbitos.

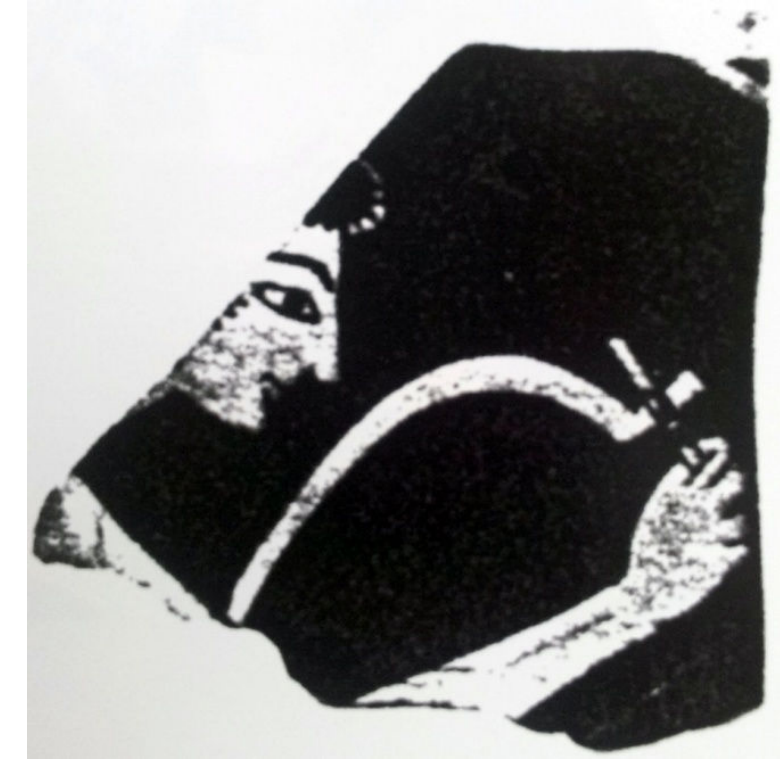

Fig. 37: Fragmento do interior de um vaso para tomar vinho. Músico afina o bárbitos, c. 510-500 a.C.

O bárbitos costumava aparecer em representaçoes em festas e banquetes, muitas vezes em duo com o aulós. Ele pode ter contribuído para o aperfeiçoamento da técnica de execução da kithára pois em geral o músico também é representado de pé, num gesto semelhante ao intérprete da kithára que é pressionando o instrumento contra o corpo, e uma faixa de pano em torno do pulso esquerdo ajuda a manter o instrumento, que parece leve apesar do tamanho. Os dedos da mão esquerda ficam livres para abafar ou puxar as cordas, enquanto a mão direita percute as cordas com o plectro.

$\mathrm{Na}$ era arcaica, as características morfológicas da phórminx se mantêm: base redonda, braços retos paralelos e círculos na caixa de ressonância, prováveis aberturas acústicas. De acordo com West,

a phórminx desaparece quando a kithára de base reta toma seu lugar no campo da música profissional. Ela "re-emerge" num contexto diferente - da música doméstica, informal, numa atmosfera relaxada. Curiosamente ainda, ela aparece muitas vezes pendurada na parede 
no fundo de uma cena, e não tanto sendo tocada como parte do conjunto; deve ter sido então vista como um "símbolo de cena" em vez de instrumento de fato (1992, p. 48).

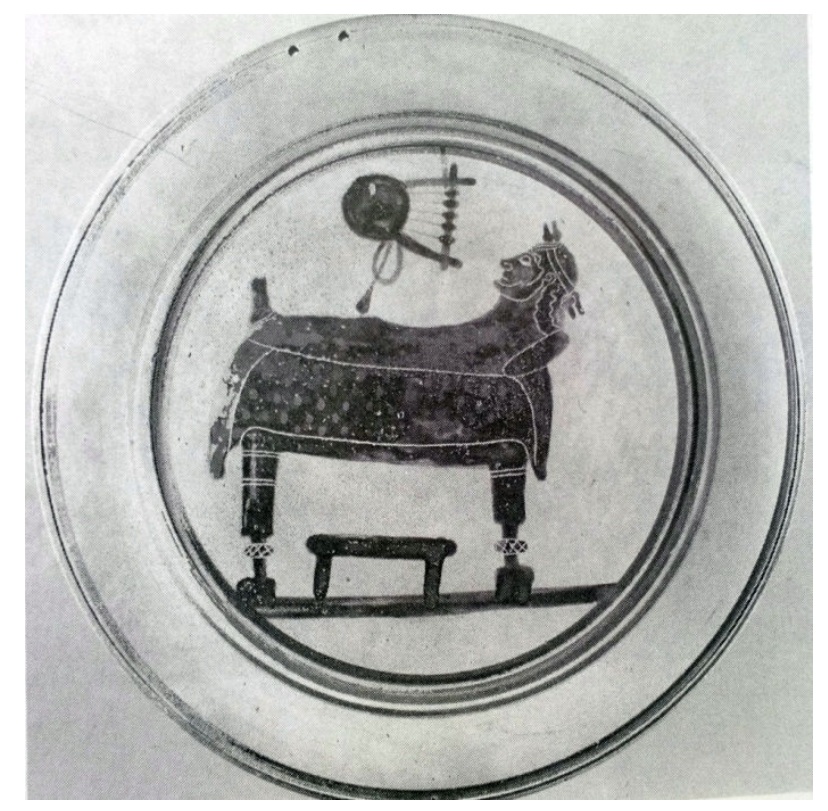

Fig. 38: Prato coríntio. Aqui, o instrumento aparece como símbolo de cena.

A phórminx vai sendo substituída como o instrumento do músico profissional, mas tanto ela, quanto a chélys e o bárbitos contribuem a seu modo para a kithára, ponto culminante da técnica construção de instrumentos de cordas na antiga Grécia, e que reuniu diversos conhecimentos acumulados, de várias partes do Mediterrâneo. ${ }^{17}$

Até o século $V$ a.C., temos indicações do termo kitharis apenas como $\mathrm{o}$ ato de tocar qualquer instrumento de cordas. Na Teogonia, kitharístes aparece como o músico que toca o instrumento de cordas. O mais antigo fragmento conhecido em que aparece o termo kithára com um instrumento específico é o poema de Teógnis de Megara, músico de Esparta, de cerca de 490 a.C.

Mas tu, Apolo, mantém distante a insolente armada dos Medas

\footnotetext{
${ }^{17}$ Como já apontamos, o casal Marcelle Duchesnes-Guillemin propôs uma origem suméria para a kithára grega em L'animal sur la cithare, sendo o animal em questão o ornamento da lira (cf. Creese, 1997, p. 27, n.30).
} 
Desta cidade, para que as pessoas, com alegria

Pela chegada da primavera, possam sacrificar gloriosas hecatombes

Alegrando-se com a kithára e os amáveis círculos

de danças, gritando peans em volta do teu altar. ${ }^{18}$

(Teógnis, apud Maas \& Snyder, 1987, p. 31)

Apesar de só tomarmos conhecimento do termo kithára nesse poema do início do século $V$, o instrumento já existia bem antes disso. Maas e Snyder apresentam uma placa de bronze, da segunda metade do século VII a.C. (Fig. 39), gravada na armadura de bronze de um guerreiro com a imagem de um instrumento "com todas as características da kithára do período clássico" (1987, p. 32). A base é reta e os braços mais altos que o da phórminx; a curvatura dos braços e a presença de volutas ornamentais abaixo do travessão também são características da kithára; um tecido trabalhado cobre o peito e o braço direito do músico, talvez para protegê-lo, detalhe que, de acordo com as autoras, não aparece com a chélys e o bárbitos e muito raramente com a phórminx.

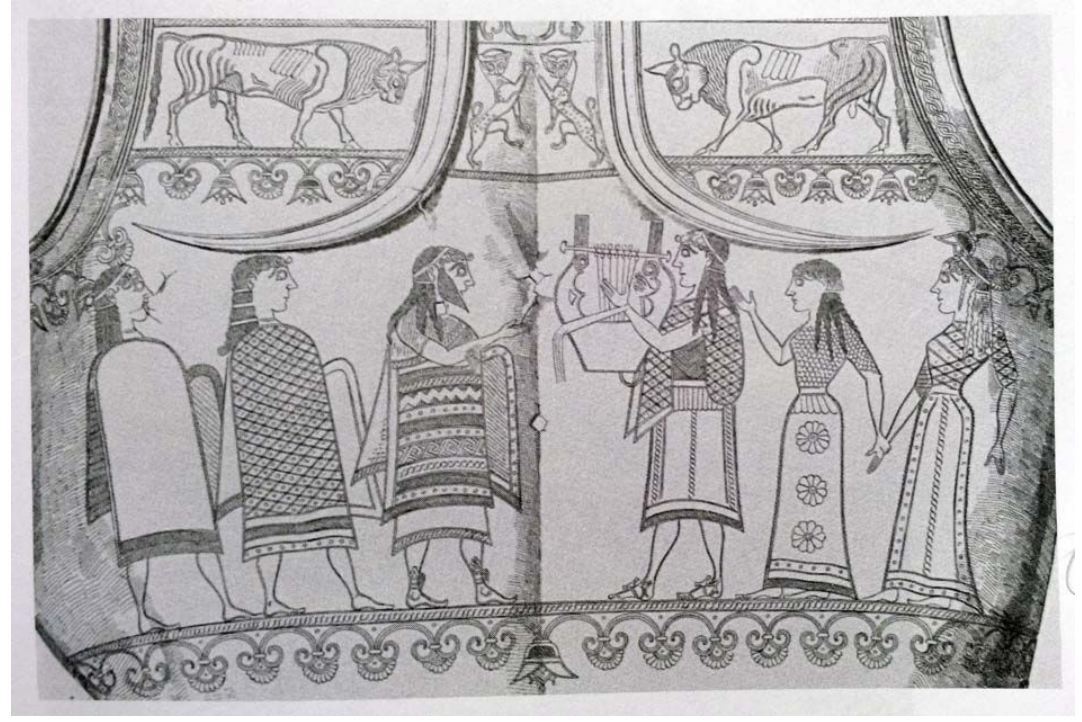

\footnotetext{
${ }^{18}$ Segundo West, os peans tinham um lugar firme na vida social privada como algo auspicioso para se cantar após o jantar, o symposium ou uma procissão de casamento. Eram frequentemente cantados por soldados e marinheiros nos momentos de exaltação, seja indo para a batalha, durante ela, ou retornando de um triunfo (2005, p. 15).
} 
Fig. 39: Placa gravada atrás de armadura de bronze. Figura do século VII a.C. na qual já aparece todos os elementos que encontraremos na kithára clássica.

Essa placa deve ter sido feita em uma ilha do mar Egeu, especula-se que em Zacynthos, mas foi encontrada dentro de um rio em Olímpia. É possível que ela tenha sido levada para alguma celebração dos jogos.

O número de representações da kithára cresce no final do século VI a.C. com variações de tamanho e número de cordas, mas o conjunto e a ornamentação não sofrem muitas transformações. West divide as liras de acordo com o design de construção. Para o autor, a phórminx e a kithára são liras de caixa ("box lyres"), distintas apenas pelo formato de suas bases, a da phórminx, redonda e a da kithára, reta. Já a chélys é classificada como uma lira de bojo ("bowl lyres"), que pode ter braços curtos (chélys) ou longos (bárbitos) (cf. 2005, p. 50).

Tanto a phórminx quanto a kithára eram instrumentos confeccionados inteiramente em madeira, diferente da chélys, que tinha braços de madeira, mas a caixa de ressonância era de carapaça de tartaruga. A chélys utilizava uma caixa de ressonância tomada diretamente a partir da natureza enquanto que a phórminx e a kithára necessitavam que houvesse a extração da madeira e o posterior trabalho nela.

A luteria da phórminx e da kithára requeria um artífice de madeira mais apurado, que tivesse conhecimento da espécie adequada a cada parte do instrumento, do melhor período de seu corte, do melhor fio para que o corte propiciasse a ressonância das vibrações ao seu longo (tal como acontece, por exemplo, na caixa harmônica dos pianos). Era necessário também saber curvar a madeira, fazer outros tipos de cortes e entalhes e dominar as melhores formas de fixação das partes, seja com cola, pregos de madeira, ou ainda por meio de nós em feixes de fibras vegetais. 
Todo esse processo envolvia uma empreitada no campo da acústica. A ressonância dos instrumentos muda de acordo com a forma de utilização dos materiais, algo que pode ser observado em diversas situações na natureza, por exemplo, ao gritar numa caverna natural ou no interior de uma carapaça de tartaruga, há uma evidente modificação e amplificação do som. É claro que os artesãos se perguntavam o porquê disso e refletiam sobre como utilizar isso em seus artefatos. Isso não significa que os antigos tivessem um conhecimento acústico tal como concebemos hoje. Seguimos Everson quando diz que

conhecimento é indubitavelmente um plano epistemológico importante mas não é o único plano que deveria ser de interesse do epistemólogo. Uma das coisas que os antigos têm para nos dizer é que os âmbitos dos planos cognitivos em que um assunto pode estar é muito mais vasto que em geral a epistemologia contemporânea percebeu. Mesmo que não aceitemos as categorias cognitivas que nos foram deixadas pelos antigos, nosso sentido de empreitada epistemológica só pode se enriquecer ao refletirmos sobre as coisas que eles têm a dizer acerca de nossas relações cognitivas com o mundo (1990, p. 5).

Toda essa atividade técnica dos gregos interessa à epistemologia musical. Landels chama a atenção para caixas de ressonância da chélys, que aparecem em iconografias do séc. V a.C., que não têm o formato oval, como as carapaças da tartaruga, mas têm asas nas laterais onde ficam inseridos os braços (2000, p. 62-3) levando-o a sugerir

que essas pinturas representem uma mudança na construção, envolvendo o uso de uma estrutura de madeira (...) Os braços seriam fixados na superfície frontal por meio de pinos. Esse conjunto tiraria toda a pressão do casco de tartaruga e a transferiria para a estrutura em madeira (2000, p. 63-4). 


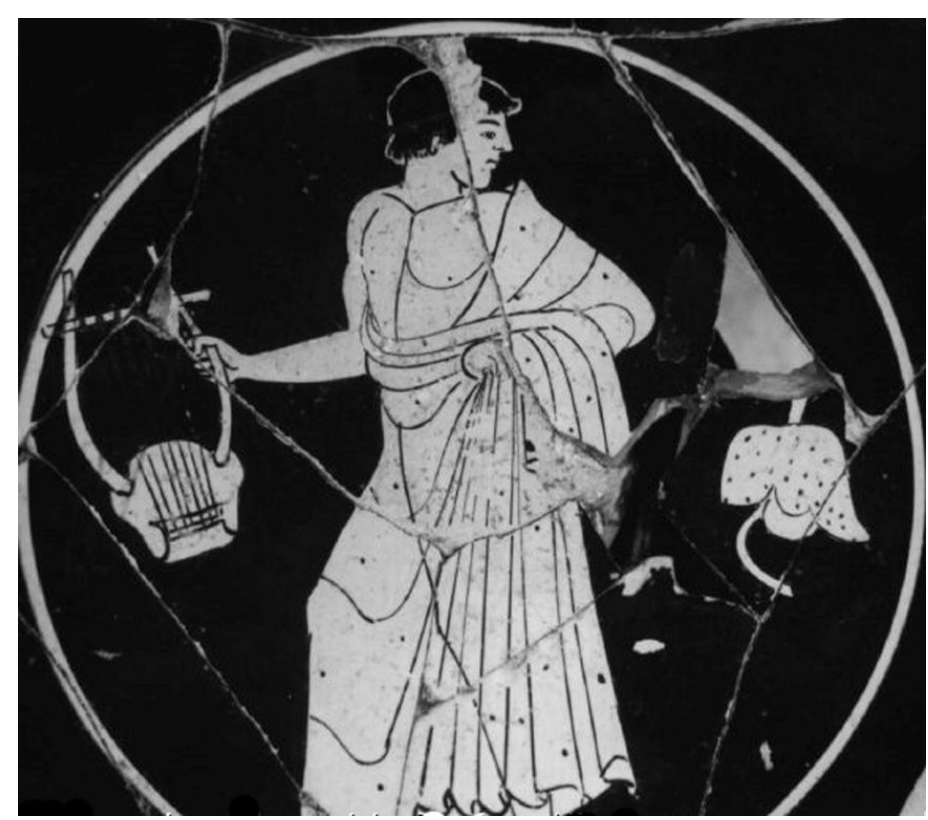

Fig. 40: Jovem segura lira com caixa de ressonância, aparentemente, de madeira.

O autor observa que a objeção seria que o instrumento ficaria muito pesado e as representações pictóricas parecem mostrar um instrumento leve (2000, p. 64). De qualquer modo, mais uma vez, se de fato as caixas da chélys começaram a ser feitas em madeira, essa pode ser uma técnica de construção intermediária, que contribuiu para a kithára, reforçando a nossa ideia de que a kithára utiliza princípios tanto da chélys, a ideia de montagem dos braços separadamente, quanto da phórminx, a caixa de ressonância de madeira. Os braços independentes fixados posteriormente na caixa de ressonância haviam aparecido definitivamente com a chélys, na medida em que a phórminx era manufaturada em uma peça única. Esse traço diferenciava a kithára do instrumento monóxilo das musas, a phórminx, e aproximava-a da técnica de montagem da chélys.

A divisão organológica de Ceulemans, apesar de ter sido feita para tratar de um instrumento de um período histórico muito posterior ao do presente estudo - o violino - é bastante pertinente ao estudo dos instrumentos musicais do ponto de vista da técnica. A autora 
classifica os instrumentos em monóxilos e de assemblage (montagem) e mostra que houve uma passagem de um modo de construção a outro.

No século XVI, o instrumental de cordas passou por uma das mudanças mais importantes da sua história: o abandono progressivo, no campo da música erudita, de técnicas de fabricação herdadas da Idade Média, em particular a feitura monóxila bem preservada na luteria popular. Boa parte dos instrumentos de cordas e braço eram feitos num bloco único e a única peça que era fixada era o tampo. (2011, p. 69)

Isso parece ter acontecido também na passagem da idade do ferro para a inovadora era arcaica. A construção monóxila, como a cama construída por Odisseu, utiliza um número menor de técnicas e ferramentas. Dubord mostra que, desde a idade do ferro,

ferramentas como o serrote, o martelo, o cinzel e a broca já haviam passado por transformações em relação aos antigos protótipos de bronze, e despontam os primeiros moldes e alicates. Graças ao conhecimento das técnicas de fusão do terceiro milênio a.C., as ferramentas mencionadas adquirem uma estabilidade e solidez superiores $(2014$, p.16).

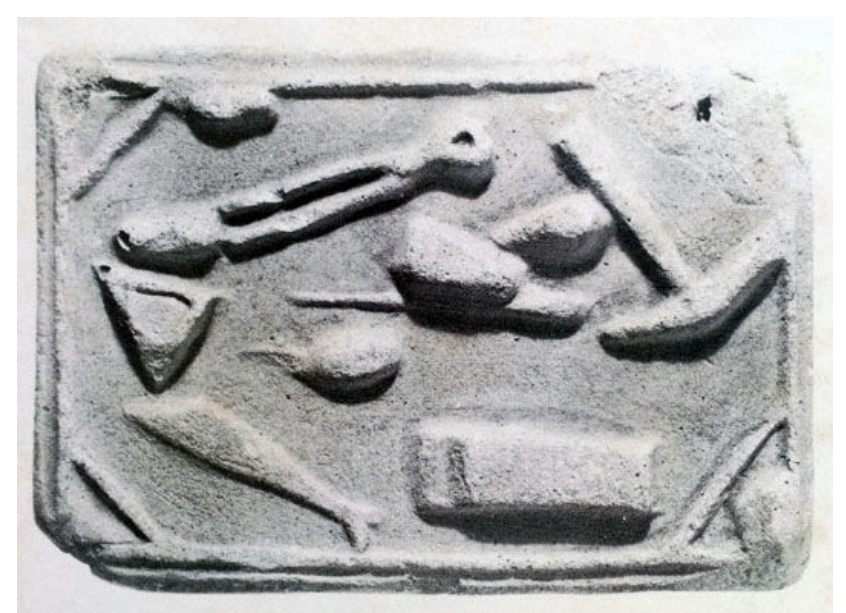

Fig. 41: Placa de terracota do túmulo de um artesão de Alexandria, mostrando as suas ferramentas. 
A luteria monóxila era mais simples que a de montagem, pois o instrumento era trabalhado diretamente na madeira, e apenas o tampo fixado depois. As partes laterais e o fundo ficam relativamente espessos e absorvem boa parte da ressonância das cordas. Se o isntrumento tiver um estandarte, o cavalete se mantém fixo apenas pela pressão das cordas. No período arcaico, além dos serrotes, as ferramentas de traçado, como o compasso, as de encaixes como prensas, as de serragem, entalhe e perfuração compõem o arsenal do marceneiro.

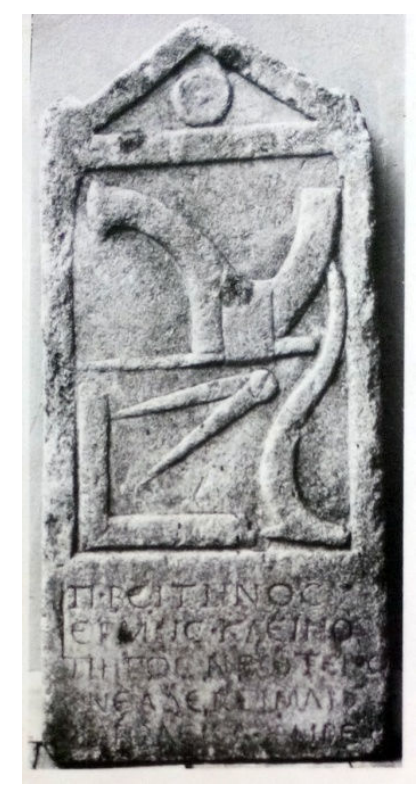

Fig. 42: Estela funerária de P. Beitenos Hermes, marceneiro especializado em camas.

Uma ferramenta sobre a qual ainda persistem dúvidas sobre a data de seu surgimento na Grécia arcaica é a plaina, essencial para o trabalho na espessura das madeiras e no seu nivelamento. Segundo Bouillot e Chatellard, as primeiras provas da existência de plainas foram encontradas em sarcófagos gregos no Egito do século IV a.C., em que foram identificados contornos e ranhuras que só poderiam ter sido feitos com plainas (2010, p. 10). Segundo os autores, a obra de referência para o estudo da plaina é a de Greber

[que] concluiu que o nascimento da plaina ocorreu na Grécia durante o brilhante período de Péricles, ou seja, no século $V$ a.C., mas os únicos 
vestígios sólidos só surgem no século IV a.C. nas colônias gregas, em que o artesanato em madeira parece ter sido mais complexo (2010, p. 10).

Considerando que as grandes inovações técnicas ocorreram no período arcaico, é mais provável que a plaina tivesse nascido um pouco antes que o imdicado pelo autor, entre os séculos VII e VI a.C., e o artefato que nos leva a sugerir isso é justamente a kithára que, sem a plaina, não poderia ter pranchas de madeira suficientemente finas para a sua confecção. Como menciona Ceulemans,

Para a técnica de montagem e marchetaria são necessários utensílios específicos para trabalhar a madeira, em especial, a plaina de precisão que permite cortar a madeira bem fininha, condição fundamental para a curvatura da madeira a calor (Ceulemans, p. 87-8).

Talvez não existisse uma plaina sofisticada, mas dados os registros da amplitude sonora da kithára, o conhecimento de técnicas de raspagem com fino acabamento parece-nos estar presente já no período arcaico.

Ampliando então a classificação de Ceulemans para os instrumentos gregos, podemos dizer que a phórminx é basicamente um instrumento monóxilo enquanto a chélys-lyra e a kithára, de assemblage. A ideia de que a kithára reuniu princípios tanto da chélys quanto da phórminx talvez explique uma variante da phórminx que apresenta uma barra na frente das cordas como se fosse um traste (ver essa variante como símbolo de cena na fig. 73, p. 148). Landels considera que

sua função é duvidosa, mas parece significativo que ela fique a cerca de $1 / 3$ do comprimento vibrante da corda acima do cavalete. Se isso for verdade, pode ser que os dedos da mão esquerda o usassem como um traste, pressionando os dedos contra ele, e assim tocando todas as 
notas do registro normal uma $12^{\mathrm{a}}$. acima (ou seja, uma oitava mais uma quinta (2000, p. 48).

De fato, isso ampliaria bastante seu âmbito de tessitura e é possível que ele tenha sido um instrumento intermediário, pois utiliza uma técnica de performance mais próxima da kithára e pode inclusive ter sido o motor de mudanças estruturais nela.

Outro instrumento de design levemente diferente ficou conhecido kithára ou lyra de Thamyris (Fig. 43). Ele aparece em uma cena pintada em uma cerâmica do final do século $V$ a.C., atribuída ao pintor Pollion. Três sátiros nus a carregam em frente a um auleta paramentado com seu chiton comprido. Suas caixas de ressonância e os braços curvos lembram a chélys, mas a caixa é feita de madeira e tem a base reta, própria da kithára. A curvatura dos braços é exagerada quase chegando a um círculo, mas suas extensões, acima do zygón, são retas o que permite a Landels supor que o zygón poderia ser "ajustado em alturas diferentes, apesar de nada evidente sugerir isto" (2000, p. 68).

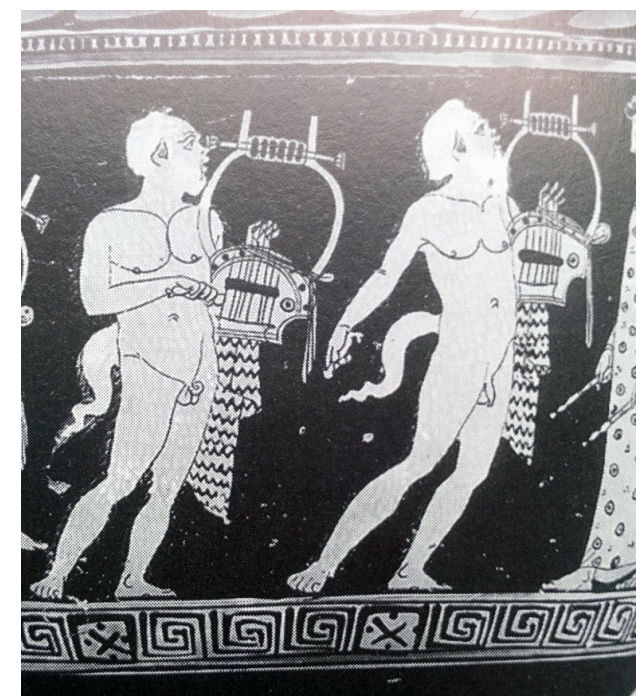

Fig. 43: Vaso para misturar vinho com água, do artesão Polion, com imagens de músicos tocando a chamada lira de Thamirys, c. 420 a.C. 
Ceulemans trata da questão de instrumentos intermediários ao mostrar o desenvolvimento do violino moderno, do século XVII, a partir da viela medieval.

(...) houve uma etapa intermediária entre os instrumentos monóxilos e os de montagem caracterizada pelo aparecimento de lados recortados (chantournées). Do ponto de vista das ferramentas, o século XII é marcado pelo ressurgimento do serrote, conhecido desde a Antiguidade mas pouco utilizado entre a queda do Império Romano e o século XI. É justamente o serrote de ponta $^{19}$ que permitiu a fabricação de instrumentos em que o cavalete, os braços e esses lados recortados fossem fabricados em uma prancha de madeira espessa, mas cujo fundo e tampo eram fixados (2011, p.87).

A autora considera que talvez seja exagerada a ideia do desaparecimento total do serrote durante o período medieval, defendida por Goodman no livro The history of woodworking tools. ${ }^{20}$ Isso também pode ter acontecido na passagem da era do bronze à arcaica, pois apesar da obscuridade em que está mergulhado o período intermediário, os estágios técnicos e suas ferramentas, uma vez alcançados, parecem difíceis de retroceder.

19 O serrote de ponta moderno possui os dentes na parte superior, permitindo o recorte da madeira.

${ }^{20} \mathrm{~A}$ autora refere-se ao clássico de Goodman, William Louis: The history of woodworking tools. London: Bell, 1976. 


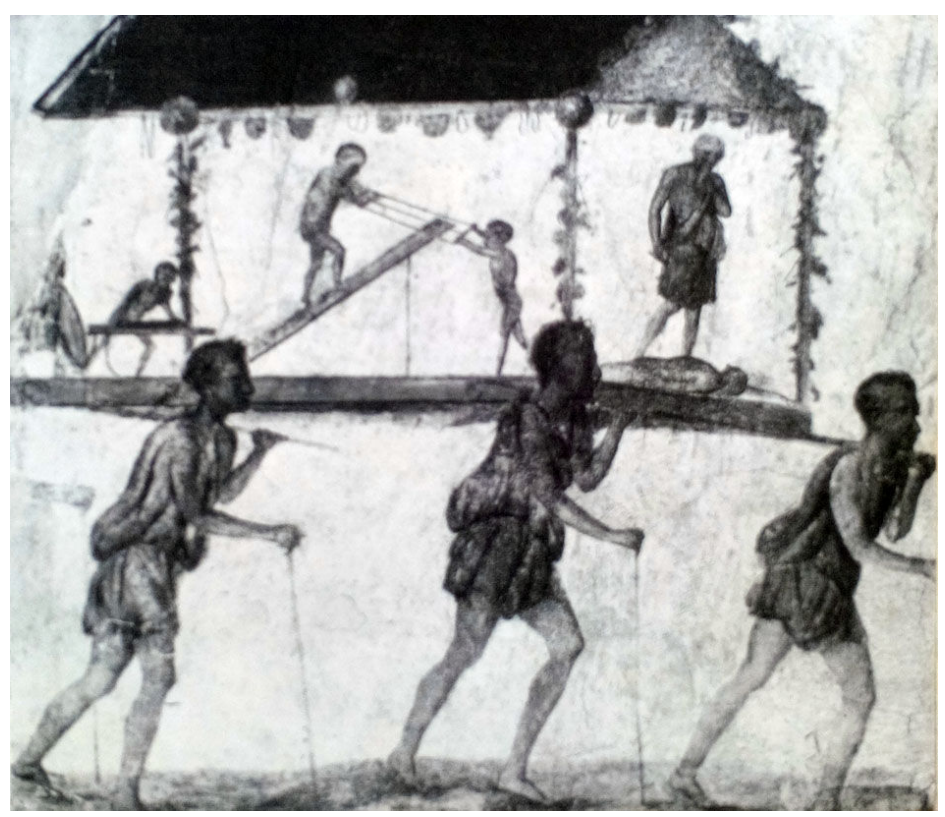

Fig. 44: "Pintura de parede em Pompeia, ilustrando um festival em honra de Perdix, o inventor da serra de carpinteiro. Ele foi morto por Dedalos, seu irmão, e um modelo do evento era carregado em procissão, possivelmente por carpinteiros" (Burford, 1972, f. 12).

Os braços (pécheis) laterais e o travessão (zygón) da kithára, como vimos, eram feitos de madeira resistente. Esse último termo, utilizado desde a idade do bronze para o travessão superior das liras, é bastante comum e a tradução mais imediata é jugo, o pedaço de madeira que une os animais em dupla para o trabalho doméstico; o verbo zygéo tem o sentido de alinhar duas coisas, dois elementos. 0 zygón pode ser ainda o fiel de uma balança e ainda o banco dos remadores em uma nau (cf. Bailly, 1963, p.884). Também o uso corrente do termo péchys tem o significado de cotovelo ou antebraço. Em um epigrama votivo do século III a.C., de autoria de Leônidas de Tarento, o termo significa uma ferramenta do marceneiro, como uma régua.

Théris, hábil com as mãos, consagra à Palas Atena uma régua inquebrável, um serrote longo curvado do lado do gume, um machado, 
um polidor, ambos fáceis de manusear e uma pua de girar, ferramentas que cessou de usar (Antologia grega, 6, 204). ${ }^{21}$

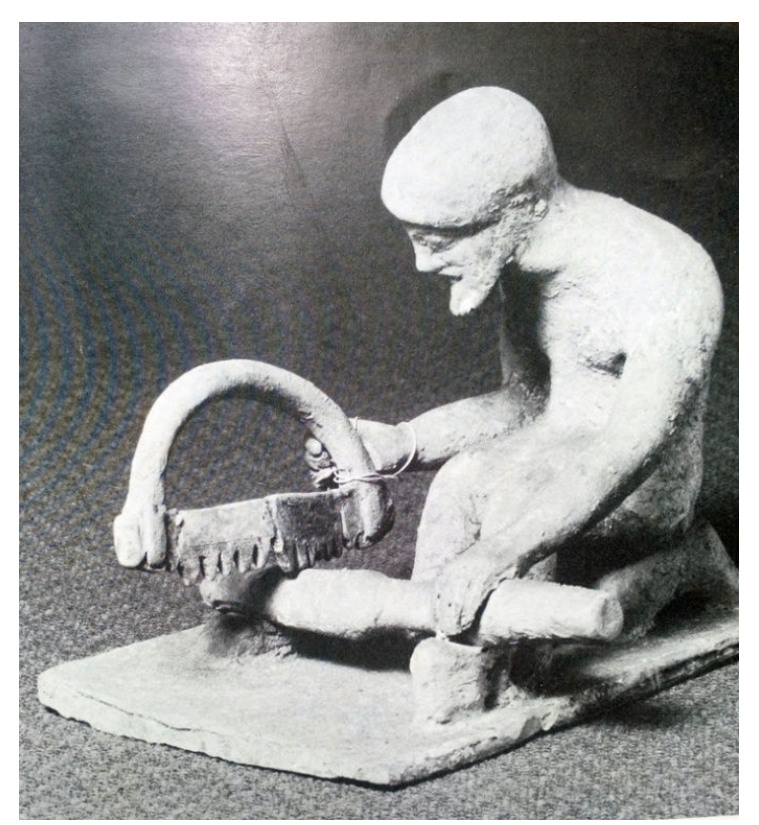

Fig. 45: Terracota da Beócia mostra um serrador em ação, séc. V a.C.

O fato dos braços da kithára serem montados separadamente é bastante relevante no sentido de aumentar a tensão e, consequentemente, a ressonância das cordas. O conjunto era fixado por meio de encaixes tipo macho-fêmea, ou presos seja com cordas, prego ou cola, tal como os móveis e os navios. Do mesmo modo que na chélys-lyra e na phórminx, o zygón ligava os dois braços da kithára, mas nela, eles ultrapassam o tamanho das cordas, o que, de acordo com Landels, talvez auxiliasse na ressonância acústica do instrumento (cf. 2000, p. 50).

\footnotetext{
${ }^{21} \Theta \tilde{p}$
}

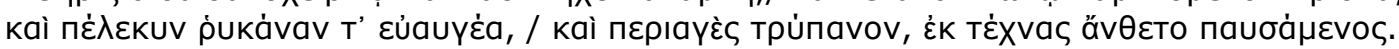




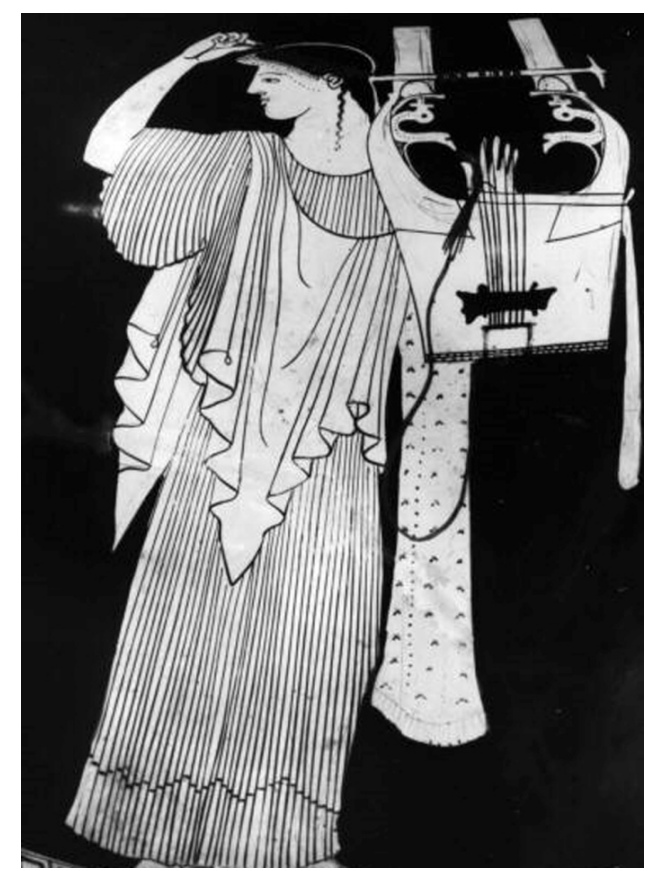

Fig. 46: Músico com a kithára. Ânfora ateniense, proveniente da Itália, c. 525-475. Pintor de Berlim.

A característica morfológica mais evidente da kithára é a sua base reta como a das harpas. Os lados da caixa de ressonância também são retos e afastam-se em linhas divergentes até cerca de um terço da sua altura total e a parte superior volta-se ligeiramente para dentro. São diversas peças montadas em um sistema de junções complexo. Segundo Bélis, a construção da kithára variou muito mais que a da lira ao longo dos séculos.

Se a lira não evoluiu quase nada entre o século $V$ a.C. e os primeiros séculos da nossa era, por outro lado, existiram dezenas de tipos de cítaras - todas com o nome kithára - mas com dimensões, estruturas e técnicas de performance bem diferentes (2000, p. 205-6).

O mecanismo dos kollópes também deve ter se aperfeiçoado bastante ao longo dos séculos, pois eles eram de extrema importância para as afinações, que se tornaram mais sofisticadas a partir do período arcaico. Segundo Landels, há controvérsias acerca do material de que eram feitas os kollópes, pois o couro de boi afrouxa ou contrai 
com o tempo, a temperatura e a umidade, e não permitiria a reafinação constante do instrumento (cf. 2000, p.54). Contudo, é comum os instrumentos musicais necessitarem de cuidados constantes e é possível que algum tipo de gordura ou óleo fizesse a manutenção do kóllops.

Burford menciona fontes literárias em que aparece o termo para o cozinheiro de cola, mas faz a ressalva de que isso não significa que houvesse "divisão completa de trabalho, nem uma especialização absoluta; a escala e a natureza da oficina proibiam isso" (1972, p. 97). O curtume, assim como a tinturaria, eram atividades rechaçadas pela pólis por exalarem um cheiro ruim, assim, é possível que os kollópes fossem entregues às luterias já preparados de alguma forma. Evidentemente que em relação a qualquer matéria prima

(...) era melhor se o artesão soubesse algo de suas origens - onde a madeira foi cortada e como foi tratada, ou onde o mármore foi cortado e como cada peça foi esculpida na face da pedra. A arte do pintor podia ser acentuada por investigadores interessados como o pintor e escultor ateniense Mikon, que supostamente descobriu um novo ocre nas minas de prata da Ática (1972, p.96-7).

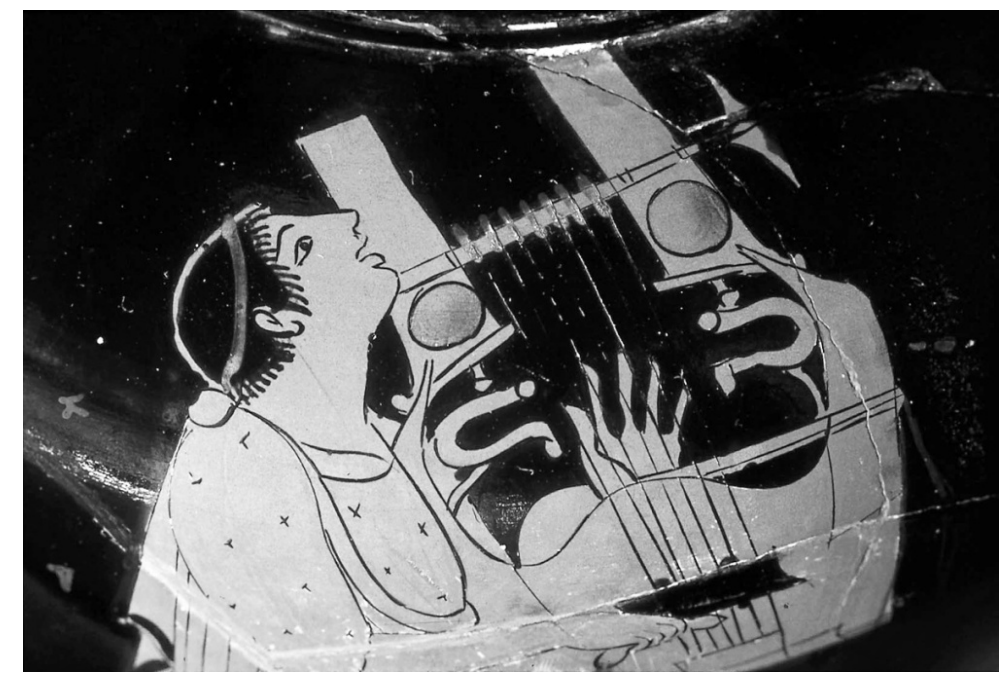

Fig. 47: Músico canta e executa a kithára. Detalhe de ânfora ateniense proveniente de Nola, Itália, c. 525-475 a.C. 
Tal como na chélys e na phórminx, as cordas da kithára tinham comprimentos iguais, variando a espessura. Elas eram feitas das chordé (tripas) dos carneiros e ovelhas. Landels propõe um cálculo da tessitura da kithára.

As cordas eram todas do mesmo comprimento $-30-40 \mathrm{~cm}$ - e devia ser difícil criar uma tensão suficiente em uma corda fina daquele comprimento, elevar a afinação mais do que uma oitava por volta do dó médio (digamos cerca de $500 \mathrm{hz}$ ), mesmo considerando que o mecanismo de afinação pudesse suportá-la. Na extremidade mais grave, uma corda mais grossa não poderia ser produzida de modo que emitisse uma nota forte e sustentada ao menos que sua tensão estivesse acima de um tom mínimo, que provavelmente daria uma nota na região do fá abaixo do dó médio (cerca de $170 \mathrm{hz}$ ). A terminologia usada para as harmoniai, que descrevia as escalas agudas de "apertadas" ou "tensas" (syntonoterai) e as graves de "relaxadas" ou "soltas" (aneimenai), se é para ser tomada literalmente, sugere que a localização geral das notas ficava no âmbito de uma 12a , fá a lá (2000, p. 58).

Mathiesen divide os instrumentos de cordas gregos em dois grupos: liras e psaltérios, respectivamente, os que têm as cordas tangidas por meio de um plectro e os que as tangem diretamente com os dedos (1999, p. 235-6). Contudo, essa classificação não contempla o fato de que alguns instrumentos da classe das liras apresentam técnicas de execução que utilizam tanto o plectro (kroúein) quanto os dedos (psállein). Isso é descrito por Landels quando fala das técnicas de performance da kithára, a partir da iconografia nos vasos.

A mão direita é apresentada normalmente segurando o plectro, que se parece com uma colher de chá, e está preso à kithára (em geral na sua parte inferior) por um cordão de cerca de 60 a $90 \mathrm{~cm}$ de comprimento. A explicação óbvia para isso é de que o plectro tinha de ser largado enquanto os dedos da mão direita eram usados para puxar as cordas, 
mas quando era de novo necessário, podia ser puxado rapidamente (2000, p. 55-6).

West confirma que na técnica de execução das liras "a mão esquerda puxava as cordas e às vezes abafava-as, enquanto a direita usava o plectro" (2005, p. 66). Considerando então que os músicos utilizavam os dois recursos nas liras, a divisão de Mathiesen, dificulta a compreensão exata da performance com as liras. Uma distinção mais estável entre harpas e liras seria o comprimento das cordas. Como vimos, nas liras, elas são de tamanhos iguais e, nas harpas, graduadas.

Como diz Ceulemans, uma das vantagens da luteria de montagem é que ela facilita o desenvolvimento de instrumentos de grande porte e possibilita um afinamento das paredes das caixas de ressonância, favorecendo a claridade do timbre (cf. 2011, p. 78). 0 volume de som da kithára era ainda enfatizado pela execução com o plectro, que possibilitava a produção de efeitos timbrísticos diferentes de acordo com a distância que o dispositivo tomava do cavalete. Para Landels, a utilização mais frequente do plectro devia ocorrer nos prelúdios e intermezzi e a execução com os dedos (psallein) quando em duo com a voz (2000, p. 56). ${ }^{22}$

No detalhe da kithára representada na ânfora de Nolan (fig. 47, p. 97), é possível observar o zygón com os discos laterais e os sete kollópes presos a ele, com suas respectivas cordas. Os encaixes dos braços com a caixa de ressonância também estão claramente retratados, e abaixo deles, alguns dispositivos que podem ter sido feitos em madeira ou metal e presos por meio de pregos ou cravos. À primeira vista eles parecem reforços à junção entre os braços e a caixa. O maior deles, por sua forma em ferradura, parece propiciar uma flexibilidade dos braços, no sentido vertical, o que permitiria um jogo

\footnotetext{
22 De acordo com Landels, as principais teorias para a performance musical dos kitharistes são a de Curt Sachs, de que o músico obtinha mais de 7 notas das cordas soltas do instrumento, que foi refutada por Winnington-Ingram. Soluções alternativas de Gombosi e Düring e Lawergen apontam para uma flexibilidade de toda a sua estrutura (cf. 2000, p. 58-9).
} 
de tensão e relaxamento das cordas e, consequentemente, dos tons. Se isso corresponder à verdade, os outros dispositivos podem ter sido coadjuvantes nesse mecanismo de flexibilização. Autores como Kurfürst defendem que a kithára possuía um sistema de pesos e molas, talvez moldadas em bronze (cf. Kurfürst, 1992, p.8). Ptolomeu, na sua Harmônica, refere-se a um movimento de empurrar as cordas na kithára, mas não comenta a respeito dos pesos e molas, de modo que não sabemos se isso existiu de fato ou ao menos se ainda estava disponível no seu tempo, século II d.C. Na pintura da ânfora de Nolan (fig. 47), o tampo frontal do instrumento parece ser curvo, mas há poucas certezas a respeito da construção dessa verdadeira máquina musical arcaica, que provavelmente pesava cerca de dez quilos.

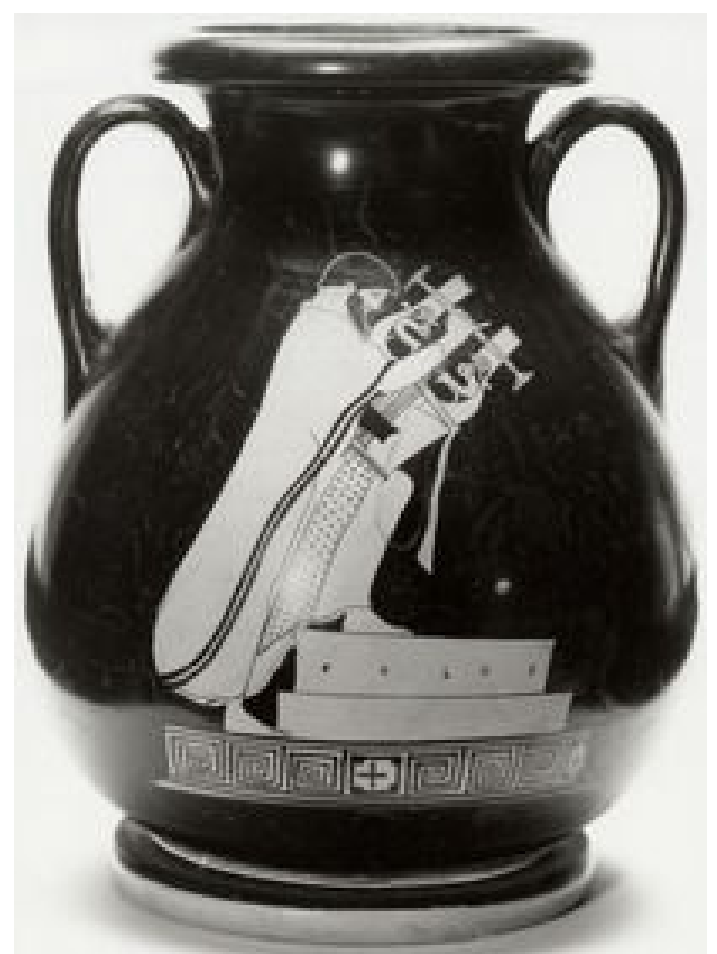

Fig. 48: Vaso ateniense com músico vestido com chiton e himation. Ele sobe o pódio (Tó ßñua) para a performance na kithára, c. 500-450 a.C.

Outra especulação curiosa é a de Landels na sua proposta de função dos discos laterais. Como isso não aparece mencionado em outras obras a respeito, parece ser mais um produto da imaginação do autor, o que não impede de ser uma possibilidade real. 
As duas linhas verticais no final do zygón representam dois discos redondos, que pode ter tido o efeito de transmitir as vibrações do ar numa altura bem aguda, que a massa total do instrumento tenderia a absorver devido a sua inercia. O fato de que eles são discos pode ser inferido por ilustrações tardias em esculturas, uma vez que os pintores representam o instrumento invariavelmente de maneira frontal. Eles eram provavelmente feitos de metal para uma transmissão do som em alta velocidade, correspondendo aos pequenos cones dos alto-falantes modernos, que transmitem frequências de áudio muito altas (2000, p. 54).

Um dos mais eminentes citaredos ${ }^{23}$ foi Árion de Lesbos, que viveu por volta de 625 a.C. na corte de Corinto. A história do resgate de Árion por golfinhos é narrada por Heródoto, no século V a.C. (cf. 1988, p. 25-6) Apesar de ser uma narrativa entre histórica e lendária, ela nos dá indícios da impressionante empunhadura da kithára e da rica vestimenta dos artistas, que reconhecemos nas representações visuais. Para ser salvo dos piratas que queriam roubá-lo e mata-lo, Árion pede que Ihe seja concedido um último pedido: cantar. Ele entoa então um nómos órthios, ou seja, uma canção tradicional de Esparta dedicada a Apolo, reiterando a associação da kithára ao deus arqueiro. O canto e a kithára de Árion deviam emitir um volume considerável de som, pois atraíram golfinhos em alto mar, que o salvaram. Para que um instrumento de cordas tivesse o alcance e a penetração exigidos nos espaços ao ar livre, onde costumavam ocorrer os concursos e festivais arcaicos, era necessário que a caixa de ressonância produzisse uma amplificação excelente.

A kithára foi o mais poderoso instrumento de cordas da Antiguidade grega e, de sua presença, como artefato, emanava uma aura de força e poder. Mesmo nos dias atuais, ela é um instrumento

\footnotetext{
${ }^{23}$ Cantor que se acompanhava na kithára.
} 
difícil de reconstruir, ainda mais que nenhum exemplar sobreviveu. Ela representa um conhecimento extremamente avançado da técnica de construção de instrumentos entre os gregos. Curiosamente, quase nada se sabe dos artífices que a criaram. Por isso, temos de olhar para outras atividades técnicas para compreender melhor a sua feitura.

\subsection{Os artífices}

No período arcaico, há uma especialização maior do artesão grego, o que não significa, como já abordamos, que houvesse uma divisão de trabalho com características industriais, mas apenas que alguns ofícios requeriam cuidados específicos e que era comum um artesão se destacar em uma determinada função.

Por exemplo, o termo zygopoiós designava aquele que reunia saberes como o tipo de madeira mais resistente, sua época de corte e os tipos de tratamento necessários para fazer não só o zygón da lira, mas também outros tipos de zygón como os utilizados em atividades náuticas, agrícolas e comerciais. Os artesãos desempenhavam um papel fundamental numa sociedade que se urbanizava, pois não era possível produzir todo o necessário ao novo oikos; há um interesse crescente por objetos como camas, cadeiras, vasos para os mais variados fins.

Em nenhum outro período da antiguidade poderia haver dúvidas em relação à grande importância econômica do artesão; a distribuição deles era um assunto de preocupação quase constante. Eles proviam não apenas as coisas essenciais - abrigo resistente, vestimentas duráveis, sapatos que vestiam bem, armas e ferramentas eficientes, muros que suportavam ataques - mas também os adornos da vida cultural. Com o artesanato, era possível ter casas, templos, vasilhames para a bebida, armaduras, complexos de ruas, fortificações e aquedutos que tanto funcionavam de maneira perfeitamente adequada quanto eram belas (Burford, 1972, p. 15). 
As inovações eram motivo de orgulho de cada uma das polei. Corinto destacava-se como centro de construção naval, pois os coríntios, no final do século VIII a.C., teriam construído as primeiras trirremes, novidade que se tornou a base do poderio naval grego. Um habitante da cidade, engenheiro Ameinokles, era tido como o responsável pela construção de quatro navios desse tipo para a cidade de Samos, uma das mais ricas e tecnologicamente avançadas do século VI a.C. (cf. Tucídides, 1987, p. 24-5). Samos era outro centro de artífices como joalheiros, escultores, arquitetos e construtores "capazes de trabalhar bases de colunas jônicas no torno, conseguindo uma moldagem exata, da precisão de uma faca" (Burford, 1972, p. 111-12), além dos chálkeus, que trabalhavam o bronze.

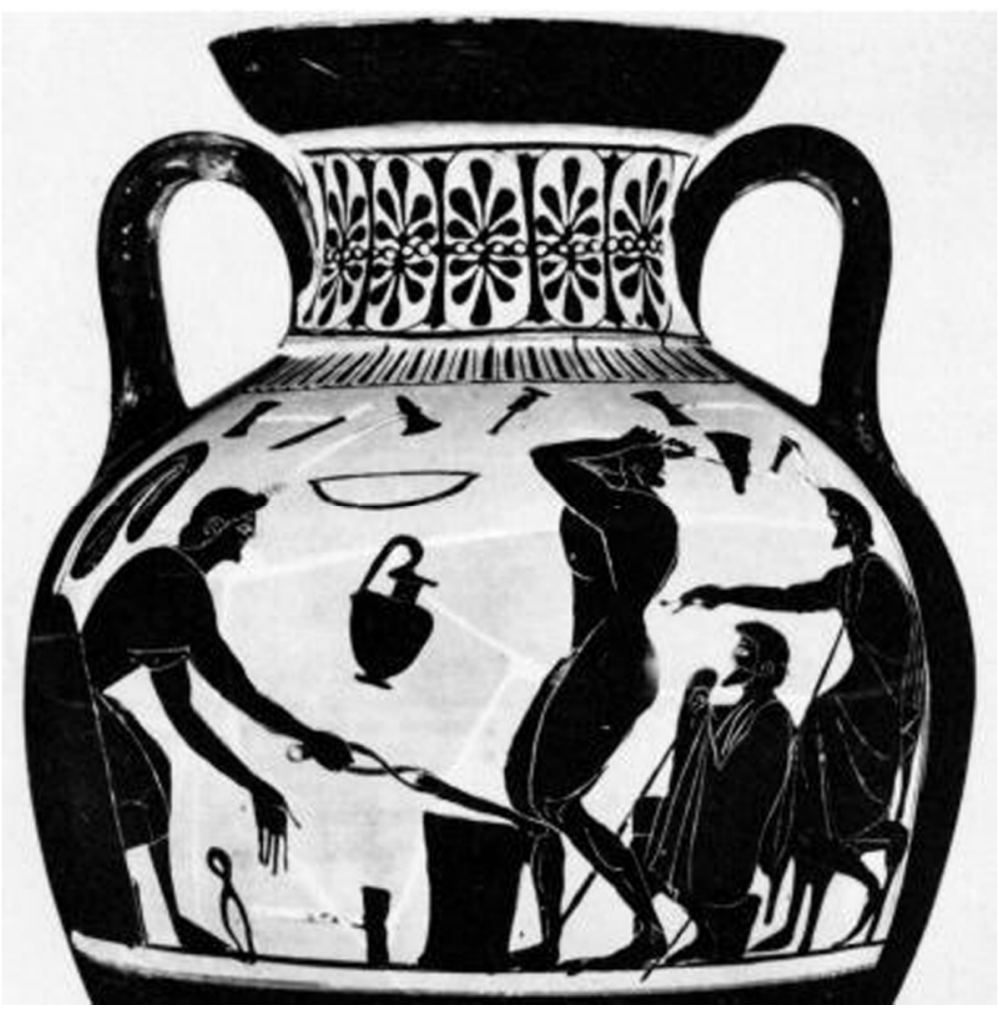

Fig. 49: Ânfora ateniense mostra ferreiros com linguetas de metal, bigorna e martelo e várias outras ferramentas penduradas: linguetas, martelos, serrotes, facão, arco de pua, e um jarro de servir vinho, suspenso. Proveniente de Orvieto, Itália, c. 550-500 a.C. 
No início da era arcaica, Samos fazia parte do grupo de cidades interessadas em inovações na esfera musical, ao lado de ilhas como Lesbos, e no continente, Esparta, Corinto e Argos. Os argivos tinham como herói o auleta Sacadas de Argos, que vencera três vezes o concurso em Delfos.

Atenas rivalizava com Corinto pela primazia da invenção de todas as técnicas com o barro. Em Corinto, Hyperbios era tido como o inventor da roda do oleiro, mas em Atenas era Anacharsis, às vezes Koroibes, o inventor de todas as técnicas relacionadas à cerâmica.

O quanto essas histórias surtiam efeito entre os próprios ceramistas e se elas ajudavam de algum jeito a promovê-los é difícil saber. O que sabemos é que um aristocrata e racionalista (para não dizer um extremista político), como Crítias, escreveu, no final do século quinto, que Atenas "foi a cidade que... projetou a roda do oleiro e o produto do barro e do forno, e tinha a cerâmica mais famosa e útil para a casa $^{24 "}$ (Burford, 1972, p. 192).

De fato, foi o ateniense que assinava as obras como Andócides que revolucionou a cerâmica com a mudança de figuras negras para vermelhas no final do século VI a.C. (cf. Burford, 1972, p. 94). O ambiente das oficinas de cerâmica não era dos mais acolhedores, pois elas exigiam outras habilidades bem menos bucólicas como a modelagem do barro no torno e a sua pintura. Primeiro, o forno tinha que ser bem construído, depois era preciso saber aquecê-lo e também resfriá-lo, tudo isso na temperatura correta, para não destruir a cerâmica.

${ }^{24}$ Critias, Fragmento I, 21, 14, 12-14, apud Burford, 1972, p. 192. 


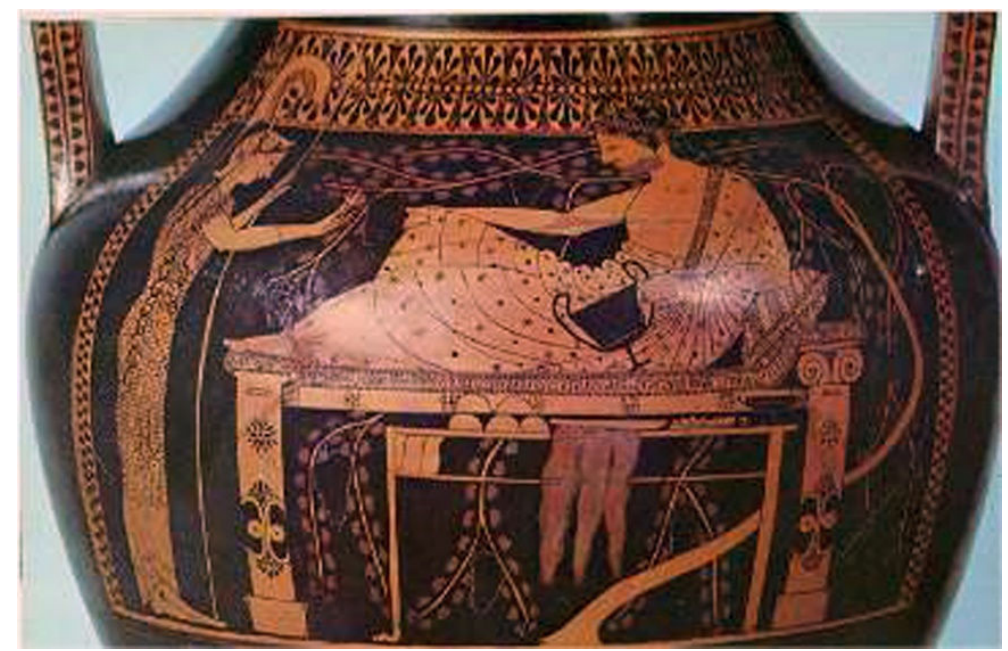

Fig. 50: Ânfora de Andócides com Héracles descansando em uma cama ricamente trabalhada, c. 520 a.C.

Para alcançar o contraste certo entre a pasta vermelha e a vitrificação negra da cerâmica ática, por exemplo, o calor no forno tinha de ser elevado a altas temperaturas com uma boa chaminé de modo que $o$ conteúdo de ferro tanto do barro quanto da vitrificação se oxidasse e se tornasse vermelha. Aí o fogo tinha de ser reduzido com madeira verde e a chaminé tampada, de modo que a falta de oxigênio tornasse o óxido de ferro vermelho em óxido de ferro preto. O terceiro e mais difícil estágio envolvia o reaquecimento do forno, apenas pelo período de tempo que permitisse que a cerâmica porosa se tornasse vermelha novamente, enquanto que a cerâmica mais densa se tornasse negra se entrasse muito ar, o vaso inteiro ficava vermelho, enquanto que se o forno fosse muito abafado, o pote perdia sua forma (Burford, 1972, p. 72). 


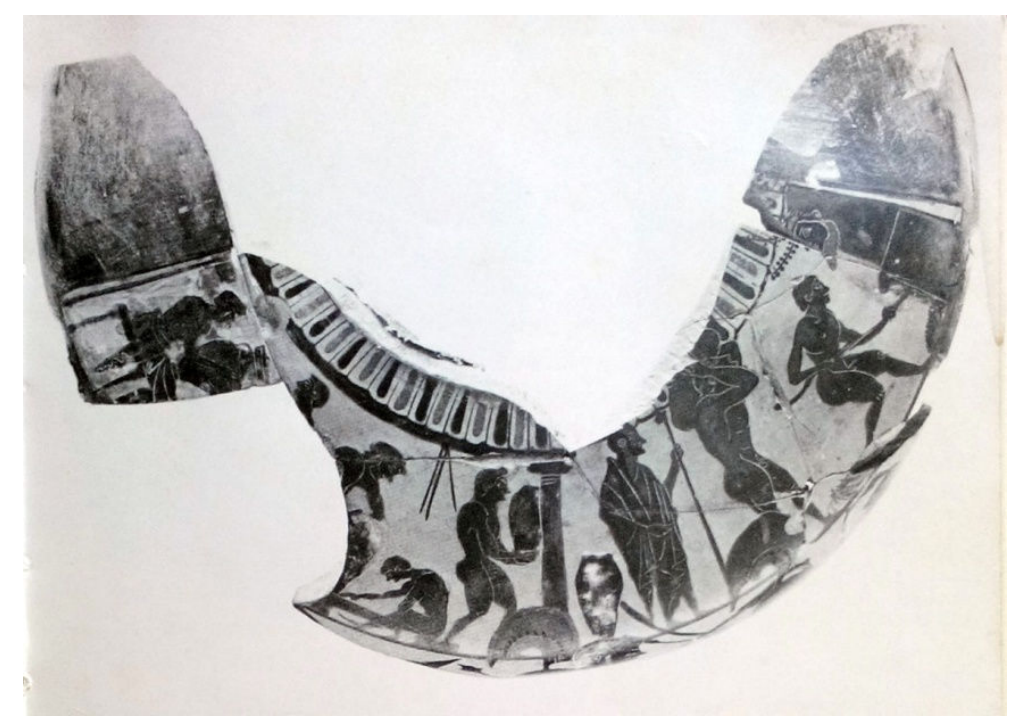

Fig. 51: Várias etapas do trabalho em cerâmica, da pintura ao cozimento. Acima, à direita, máscara apotropaica de proteção.

A perda do material afetava artesãos de diversas modalidades, mas talvez os ceramistas fossem os que corressem os maiores riscos. Os perigos eram cantados em verso, buscando afastá-los. O elogio a essa arte, que aparece no fragmento 14 dos Epigramas Homéricos, também conhecido como "hino dos ceramistas" é inversamente proporcional à intimidação aos artesãos que não fizessem corretamente o seu trabalho. A ameaça inclui invocação de cinco daimónes: Suntríbos, Smaragón, Asbétos, Sabáktes e Omodámos, em tradução livre, Estilhaço, Esmagado, Queimado, Esmigalhado e Mal Cozido.

Venha Atenas com a mão levantada sobre o forno. Permita que os potes e todos os pratos sejam bem torneados e bem cozidos; deixe que eles alcancem um bom preço e sejam vendidos em quantidade no mercado. Garanta que os ceramistas obtenham um grande ganho e que eu possa cantar para eles. Mas se vocês fizerem falsas promessas, então eu chamo os destruidores de fornos, Suntribos e Smaragon e Asbetos e Sabaktes e Omodamos que podem trazer muito dano a essa arte (Fragmento 14, Hinos Homéricos). 


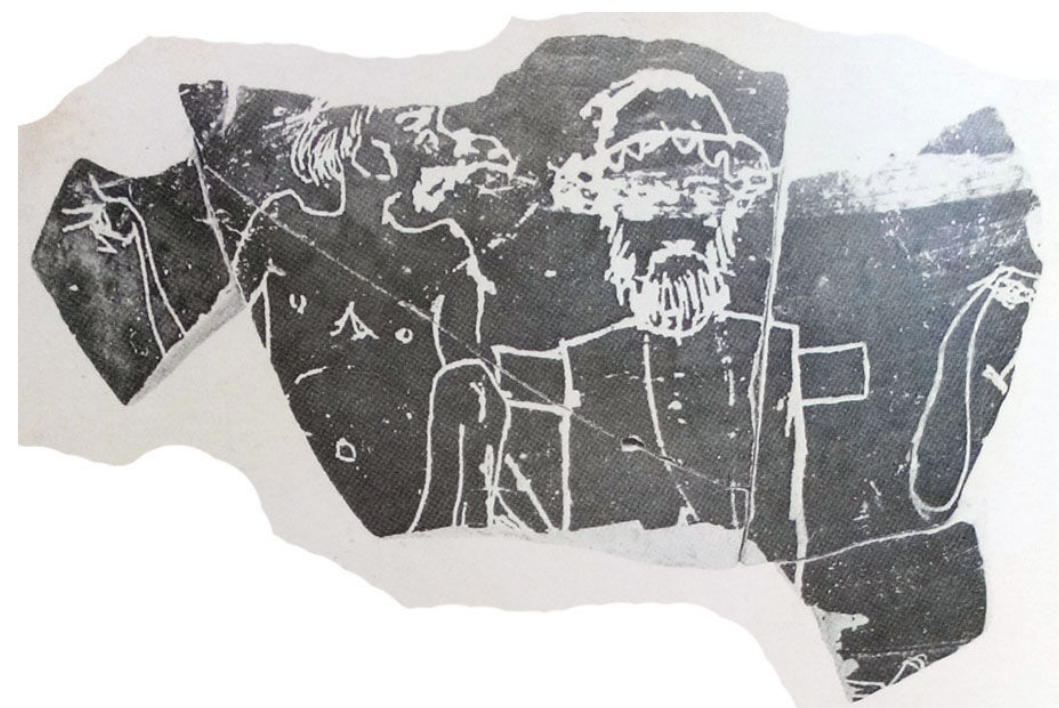

Fig. 52: Placa de terracota encontrada na oficina de Phidias com dois artesãos e um busto entre eles que, de acordo com Burford, pode ser um símbolo de proteção.

Os luthiers também tinham as suas preocupações pois, com o desenvolvimento da música, certamente houve um incremento da atividade nas oficinas e os artesãos tinham de pagar seus fornecedores, desde aqueles que sabiam preparar o couro e fervê-lo para a fabricação dos kollópes, provavelmente sapateiros, até os que comercializavam materiais de regiões distantes como os cascos de tartaruga, o marfim e os metais. 


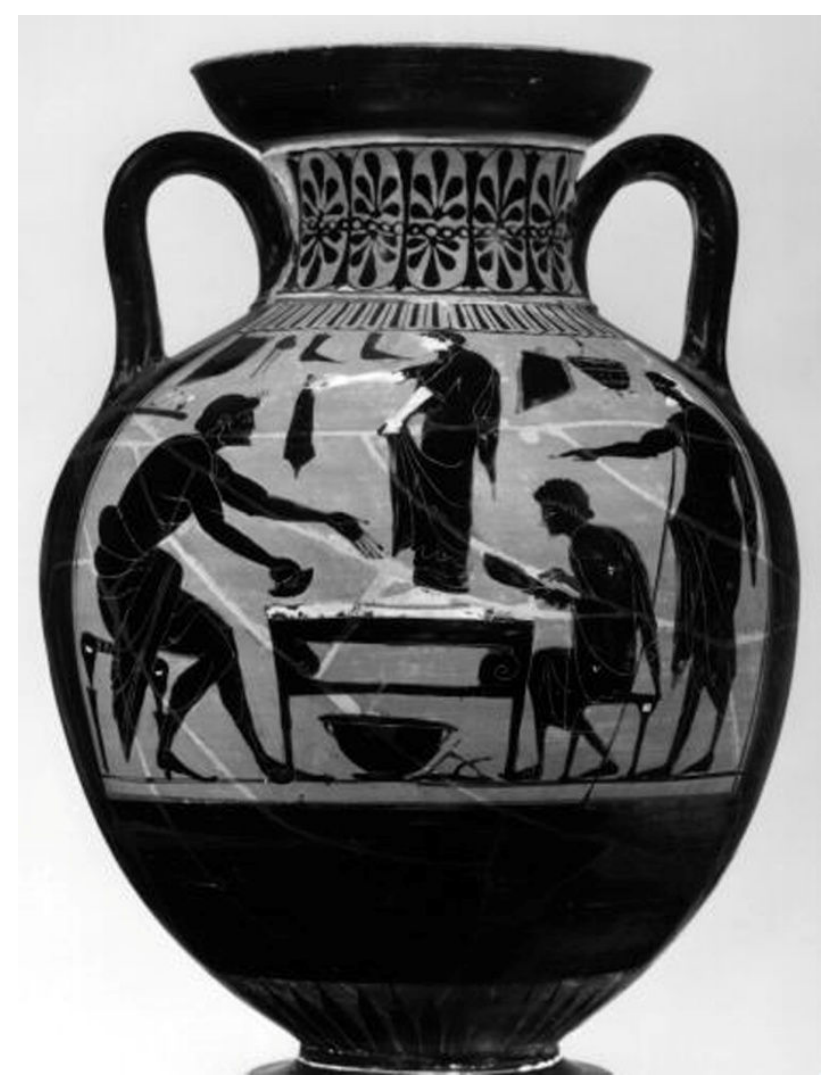

Fig. 53: Ânfora ateniense mostra sapateiros sentados com clientes. Sandálias no chão, pinças e instrumentos perfurantes. Na prateleira da parede, couro, esponja, sapatos e vasilhas. Proveniente de Orvieto, Itália, c. 550-500 a.C.

Um ateliê arcaico seria equipado com as ferramentas de ponta de seu tempo, se fosse bem situado, como nas cidades em que se realizavam os grandes festivais - Delfos, por exemplo - ou nas quais houvesse uma profusão de determinada matéria prima, como Tebas, famosa pela fabricação de palhetas para aulói devido à espécie arundo donax abundante em seus pântanos.

Obras de grandes proporções pediam também grandes oficinas reunindo várias atividades técnicas, evidentemente isso era mais comum no caso da escultura ou a pintura de grandes painéis. No século VI a.C., a cidade de Argos era um dos polos da escultura grega com os artistas Polymedes, Hagelaides, professor de Fídias, e ainda o velho e o jovem Policleto. Este último, no século $V$ a.C., concebeu racionalmente suas inovações e as codificou em um tratado conhecido como Kanon, hoje perdido, que estabelecia proporções de beleza entre 
as partes do corpo. Autores como Leftwich consideram que Policleto tenha tido importância no âmbito da medicina hipocrática, pois "revolucionou o modo como o corpo humano e suas atividades eram concebidas" (1985, p.38).

Os escultores costumavam trabalhar com a retaguarda de pedreiros e entalhadores de pedra, como Polyxeno e seus filhos Chremons e Lysiadas, que em Argos cortaram a pedra para o templo de Epidauros, e depois trabalharam na superestrutura (cf. Burford, 1972, p. 85).

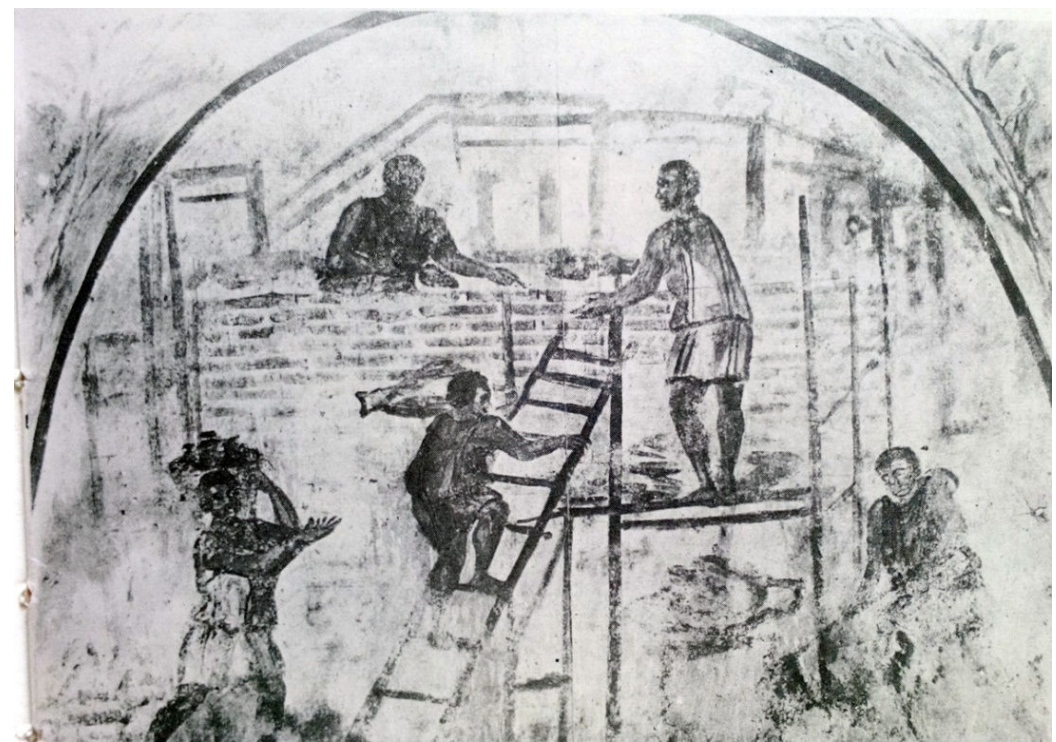

Fig. 54: Uma pintura de parede do período romano, da tumba de Trebius Justus, mostrando pedreiros em serviço.

Os escultores eram muitas vezes também arquitetos, como Fídias, que fundia bronzes e trabalhou na construção da acrópole ateniense. Nas obras, os carpinteiros compartilhavam princípios com os construtores em pedra e os escultores, e começaram a criar artefatos para levantar pedras de um lugar para o outro (cf. Burford, 1972, p. 102). 


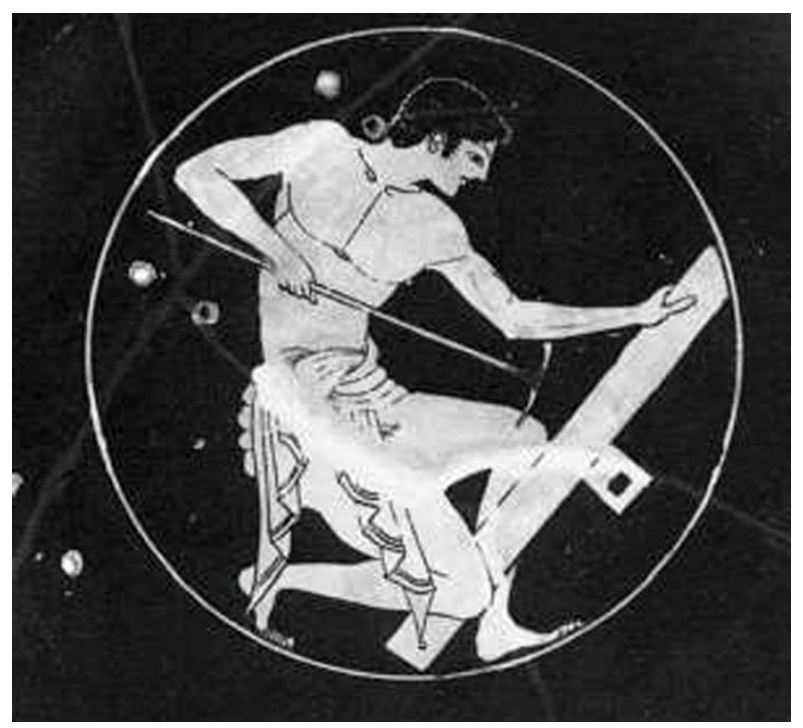

Fig. 55: Imagem de carpinteiro em fundo de taça. Cerâmica ateniense vermelha proveniente de Chiusi, Itália, c. 525-475 a.C.

No caso de grandes escultores, oficinas inteiras podiam ser montadas para eles no local dos monumentos, pois carregar as obras era mais difícil que fazer no próprio local. Fídias, no século $V$ a.C., teve seu estúdio em Olímpia, cidade que recebia os Jogos Olímpicos. Lá, ele construiu a imensa e magnífica estátua de Zeus, em ouro e marfim, considerada uma das sete maravilhas do mundo antigo, da qual, além dos relatos, nada havia restado. Contudo, em 1958, o ateliê de Fídias em Olímpia foi encontrado por uma equipe de arqueólogos alemães. Nas escavações, o grupo encontrou ferramentas, como cinzéis de vários tamanhos, pedaços de marfim, fragmentos de vidro e metal e moldes de terracota, que teriam sido usados na estátua de Zeus, todas datadas de 430 a.C. Mas a confirmação de que era de fato a oficina do escultor veio com a assinatura em um vaso: "Eu pertenço a Fídias" (cf. Price, 2002, p. 59-77). 


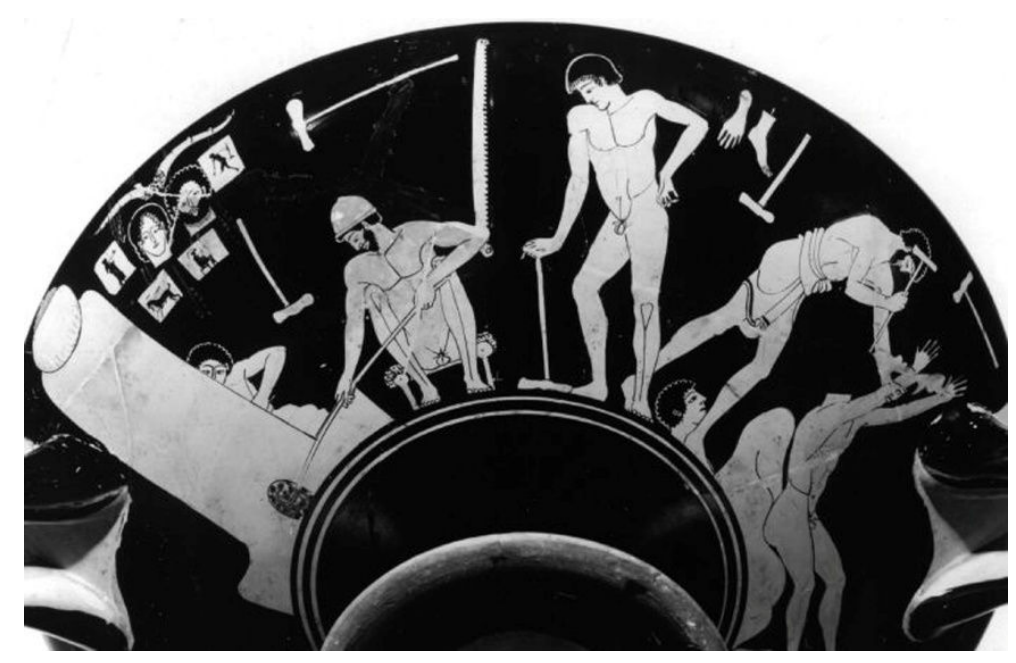

Fig. 56: Cerâmica vermelha ateniense mostra ceramistas e escultores trabalhando juntos no forno; aparecem martelos, estátuas inacabadas e no alto, à esquerda, croquis. Proveniente da Itália, c. 500-450 a.C.

Burford chama a atenção para as assinaturas dos artesãos, argumentando que elas são um indício do lugar de destaque que os artesãos tiveram na Grécia, de modo diferente que em outras civilizações antigas, mediterrâneas ou orientais, nas quais em geral eles eram anônimos.

As primeiras assinaturas são sintomáticas do novo senso de individualismo que se manifestou no séc. VII a.C. e desde então tornou-se uma das características que distingue acentuadamente os gregos dos povos do Oriente Médio (1972, p. 212).

O autor faz um inventário dessas assinaturas em vasos e bases de estátuas, como a do escultor Achermos, do século VI a.C.: "Apolo, lançador ao longe, recebe essa bela estátua, uma das obras realizadas por Achermos em sua sophia". Havia assinaturas conjuntas como a dos escultores de Argos, Eutélidas e Chrysothemis, em que se lê que "eles conheciam a sua téchne a partir de seus antepassados". E há ainda as assinaturas do escultor Kapiton e do pedreiro Iamouarios, em um pequeno templo próximo da cidade de Periandros, que diz que a 
contrução foi realizada "por homens sophotéchneies" (cf. Burford, 1972, p. 208-9).

Certamente, para muitos artesãos sobre os quais temos informações sobre sua arte, muitos outros permanecem anônimos como a dos fabricantes de velas de navios, talvez por serem feitas por mulheres ou escravos. A observar pelos vestígios, os luthiers não tinham o hábtio de assinar os instrumentos musicais, talvez por terem consciência de que os materiais não resisitiriam ao tempo. Assim, pouco se sabe sobre quem foram eles. Quando chamados pelo termo genérico organopoiós, sabíamos que ele seria um fabricante de ferramentas, entre as quais poderiam ser incluídas as musicais. Mas existiam também denominações para especializações como o fabricante de liras, lyropoiós, o fabricante de tubos de instrumentos de sopro, aulopoios, assim como os salpingopoiói, talvez uma especialidade diferente por lidar mais diretamente com metal, mas ambos tinham de conhecer como se comportavam colunas vibrantes de ar. Platão utiliza em vários diálogos os termos dos especialistas construtores de instrumentos, mas em geral para inferiorizá-los como pessoas que sabem fazer algo, mas não sabem como utilizá-lo (cf. 289b-c).

Um documento em pedra bastante interessante é a estela funerária de um compositor, em que uma canção com a letra e a notação do mélos é assinada por Seikilos, filho de Euterpe (Fig. 57). Ele mandou gravar as seguintes palavras: "Eu sou uma uma imagem de pedra. Seikilos me colocou aqui como um sinal duradouro de lembrança imortal" e em seguida a canção, com a letra e a escrita musical: 


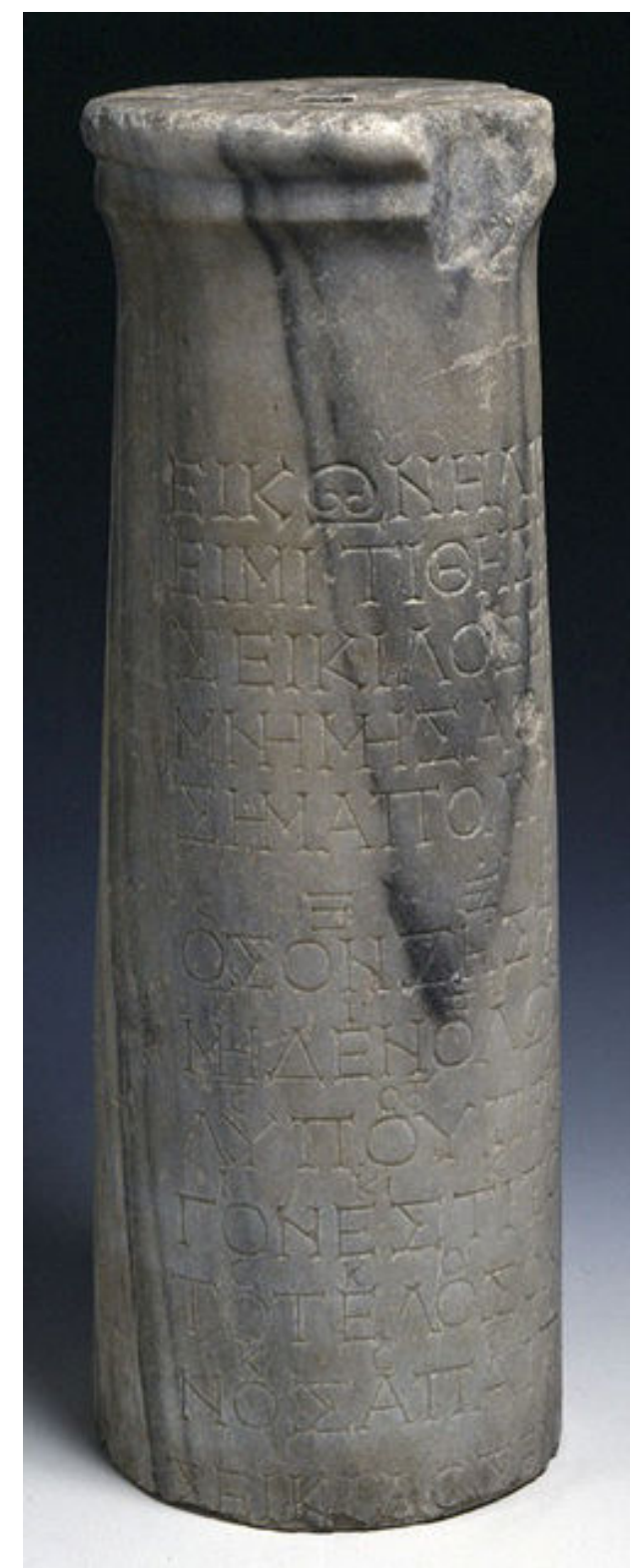

Por toda a vida, brilhe

De nada se aflija

Pois breve é a vida

E o tempo cobra o seu télos.

Seikilos, filho de Euterpe
"Ooov לṇ̃s paívou

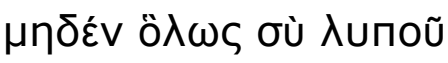

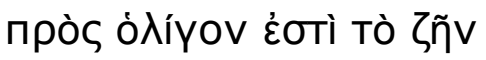

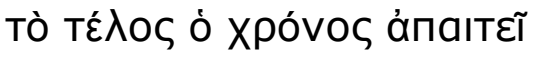

Fig. 57: Epitáfio de Seikilos, fragmento e inscrição epigráfica do compositor Seikilos, o Siciliano. São 13 linhas, com notação musical acima das linhas 6 a 11. Poema e notação musical. Século I d.C.

A partir de textos antigos, Bélis localizou o nome de um rico aulopoiós do período clássico, Teodoro, pai do orador Isócrates. Ele possuía uma oficina com escravos para o serviço, portanto ele não era bánausos, que era um termo utilizado para rebaixar alguém. Há também uma referência a um ateliê em Corinto, que teria feito um instrumento luxuoso para o famoso auletista Ismênias de Tebas, o qual teria pago a fortuna de sete talentos de ouro (cf. Bélis, 1998, p. 779- 
80), mas em geral os artífices de instrumentos musicais permaneceram anônimos.

A construção de instrumentos musicais na Grécia arcaica era uma atividade que envolvia as oficinas de trabalho em madeira, osso, chifre, junco, e também as forjas de metais. Os metais podiam ser utilizados como adornos, como dispositivos, ou eram a própria base de construção de um determinado instrumento. As técnicas de metalurgia envolviam a sofisticada produção do ferro e do bronze. Os salpingopoiós, fabricantes das trombetas sálpinx, podem ter surgido de momentos de ócio em uma oficina de bronze.

As ferramentas utilizadas pelos luthiers de instrumentos de madeira eram as do carpinteiro. Mas mesmo que um ateliê mais pobre não tivesse uma ferramenta de última geração, certamente ele não deixaria de fabricar seus instrumentos. Em todas as épocas, existe uma justaposição de tecnologias. Isso pode ser observado em uma descrição, feita em pleno século XXI, da oficina de construção de rabecas do luthier Martinho dos Santos, em Paranaguá.

As ferramentas que ele mais usa são o serrote, o facão (ele faz maravilhas com o facão, que utiliza em peças grandes e pequenas, por exemplo, para afinar o cavalete da rabeca), uma faca de cozinha, um cepilho (plaina), martelo e pregos. Quando é necessário (usar) outra ferramenta que não existe lá, ele faz a ferramenta com madeira, com impressionante senso de criatividade. Pude observar esse fato quando Martinho foi colar reforços nas laterais das rabecas e usou como grampos toquinhos de goiabeira cortados próximos aos nós, e com um racho no meio. Ou quando foi cortar a "boca" no tampo da viola. Martinho construiu uma "cambota", que seria o nosso compasso, com um pedaço de caroba, um prego no centro e pregos menores que feriam a madeira do tampo desenhando círculos perfeitos com a profundidade que ele desejasse (Gramani, 2002, p. 22). 
Assim, sabendo dessa capacidade de improviso dos artesãos constatamos que o fato de uma ferramenta aparecer numa tabela cronológica não significa que ela esteja disponível em todas as oficinas daquele período, em um determinado espaço geográfico. Na longa era da técnica anterior à industrial, desníveis de recursos entre oficinas não impediram a produção de instrumentos musicais de qualidade, mais ou menos limitados, mas eficientes para a produção da música a que se destinava.

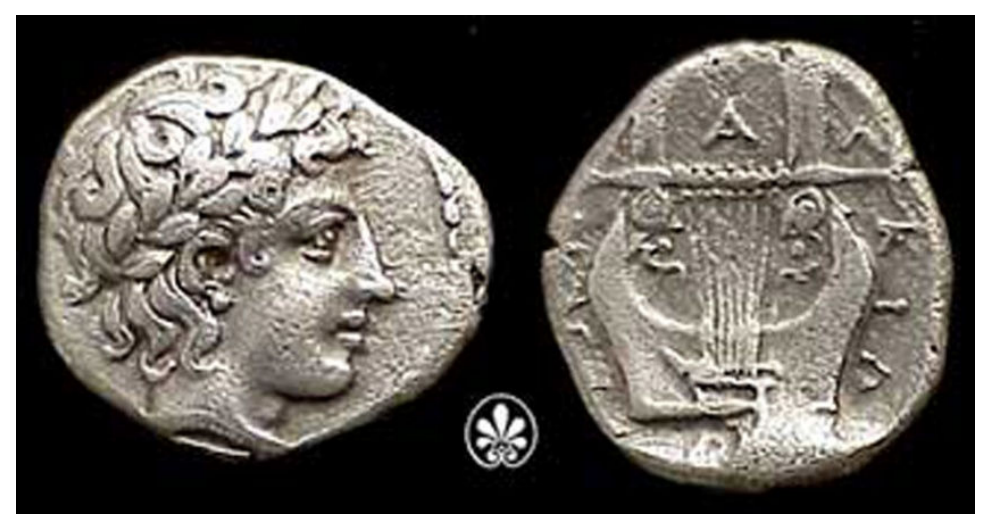

Fig. 58: Moeda macedônica de liga de bronze, c. 383-2 a.C., com Apolo em uma face e a kithára em outra.

A única evidência arqueológica encontrada até hoje de uma oficina de construção de instrumentos foi identificada em Délos, próxima ao templo de Apolo. Pelo fato de terem sido encontrados no local, além de partes de aulós, anéis de ossos, para os quais não se percebia utilidade imediata, surgiram dúvidas a respeito se de fato nesse local havia funcionado um aulopoiós, ou se o local tinha sido apenas um ateliê de trabalho com ossos. Bélis mostrou que justamente esses anéis de ossos é que comprovavam a existência de uma aulopoiós. Para tal, ela utilizou sua experiência numa lutería moderna, mostrando que, para se trabalhar o tubo de um instrumento de sopros, é necessário prendê-lo nas duas extremidades num mandril para torneá-lo, incluindo as partes nas quais serão produzidos os encaixes. Isso feito, "corta-se as peças que serviam para mantê-lo: são 
justamente essas peças, características do trabalho de luteria que comprovam a existência de um aulopoiós" (1998, p. 786).

Bélis indica em outro ponto de Délos a existência de uma oficina em plena atividade, na segunda metade do século I d.C. cujo trabalho parece ter sido abandonado às pressas "quando se fazia o polimento da superfície exterior da última seção de um aulós de marfim" (1998, p. 788). Também em Delos foram encontrados instrumentos nas residências, mostrando que a cidade era um grande centro de produção de aulói.

A clientela não faltava: as atividades musicais e religiosas eram abundantes em Délos, sem esquecer os peregrinos de passagem, que podiam eventualmente comprar um aulós para dedicar à Apolo (Bélis, 1998, p. 789).

A ilha de Delos, uma das Cíclades, foi venerada desde a idade do ferro como o local de nascimento dos deuses irmãos Apolo e Ártemis e, portanto, era onde se celebravam as festas Delia. Nesses locais de santuários, era grande a produção de oferendas votivas, peças para serem colocadas nos altares, como coroas e mesmo instrumentos musicais referentes ao deus ou deusa que se queria homenagear. 


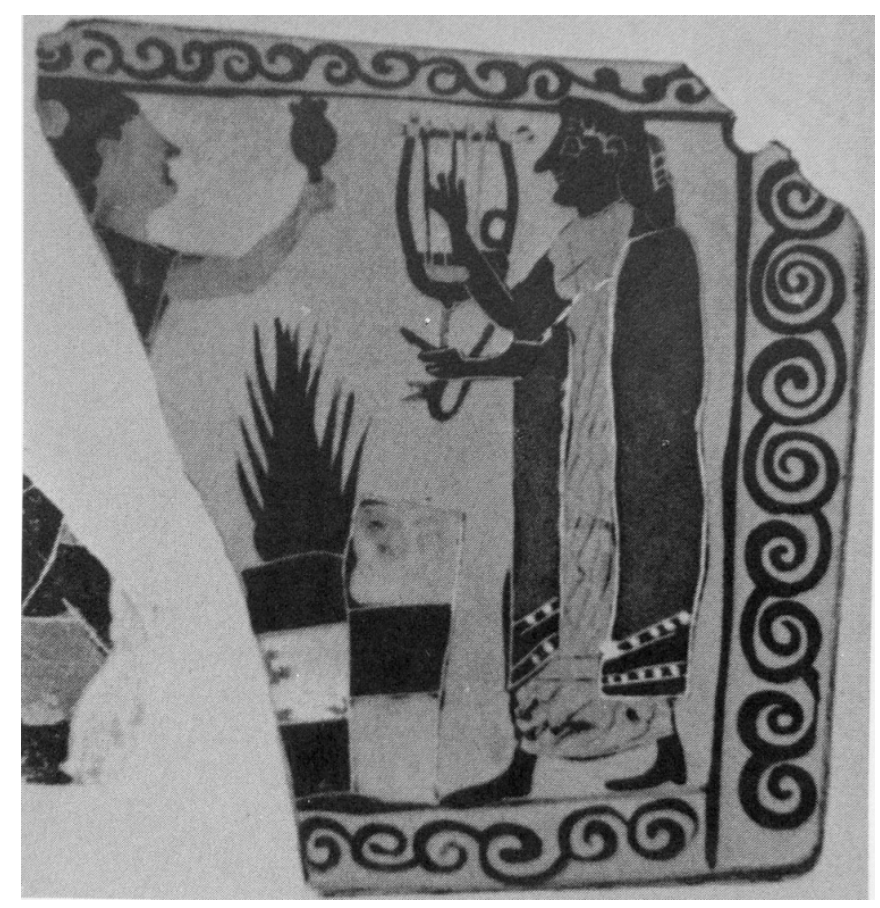

Fig.59: Fragmento de placa de cerâmica com homem tocando uma phórminx e mulher tocando um chocalho ou maraca, ambos vestidos a caráter para uma festa. Atenas, segunda metade do século VI a.C.

\subsection{Oráculos e concursos}

No século VIII a.C., em 776 a.C., ocorreu a primeira Olimpíada, a partir da qual os gregos passaram a contar a sua história, marcando também o início da Hélade. As Olimpíadas eram comemorações panhelênicas, apenas os gregos podiam participar.

$\mathrm{Na}$ cidade de Olímpia, de quatro em quatro anos, durante cinco dias, de maneira organizada, os cidadãos disputavam provas esportivas de corrida de diversas modalidades, salto à distância, lançamento de disco e vários tipos de luta, além das competições hípicas. O festival começava a ser preparado dez meses antes, quando eram enviados mensageiros às outras cidades gregas, que proclamavam a data de realização dos jogos e o início da trégua sagrada, ekecheiría ( deveriam cessar. Não era permitida a entrada de exércitos na Grécia e nem de pessoas armadas no festival. Todas as disputas eram transferidas para o espaço sagrado das Olimpíadas. Esse tempo se 
estendia até que todos pudessem retornar a seus lares. Ao lado das famílias chegava à Olímpia um colégio de sacerdotes, além de adivinhos, filósofos, oradores, músicos e outros profissionais.

Heródoto conta que, durante a guerra com os persas, esses interrogaram sobre o que estavam fazendo os gregos e a resposta foi de que estavam nos Jogos Olímpicos. Os persas teriam perguntado então a que prêmio concorriam e novamente a resposta foi de que o prêmio não era em dinheiro, ou em metais preciosos, mas na forma de uma coroa de folhas de oliveira ou de azambujeira. Um dos soldados teria então exclamado a seu general: "Ah, Maradônios, contra que homens nos leva a combater, que não lutam pela riqueza, mas apenas pela excelência" (Heródoto, 1985, p. 415-6). A verdade é que, apesar de não ganharem nada de valor material na competição, ao retornarem a suas terras, os vencedores eram tratados como heróis e obtinham cargos, isenções de impostos, entre outras regalias, mas o relato de Heródoto enfatiza o valor que tinha a noção de excelência, areté, entre os gregos.

Para o vencedor, o importante era que a notícia se espalhasse e ele se imortalizasse e isso era feito pela escrita. A partir de 554 a.C., - vencedor podia registrar a sua vitória no pedestal da estátua que entregava no altar de Zeus ou de Hércules (cf. Barros, 1996, p.11). Essa fama era representada pela musa Kléos, nome que tinha o sentido inicial de rumor, depois "notícia que se espalha" até chegar ao significado de glória. Nas representações do período clássico, Kléos aparece com um pergaminho numa caixa e mais tarde será associada à própria disciplina da História. Heródoto declamou suas histórias no contexto dos festivais. São famosas as lágrimas de Tucídides quando ouviu pela primeira vez Heródoto ler publicamente um dos capítulos de 
sua História. ${ }^{25}$ As vitórias eram cuidadosamente arquivadas pelos escritores.

Durante os festivais, as oficinas trabalhavam na fabricação ou reparo de equipamentos esportivos como bolas, aros, dardos, discos de bronze, halteres ou rodas de bigas e também dos instrumentos musicais dos profissionais que se apresentavam ou competiam.

Os festivais tinham tanto um caráter sagrado quanto profano. Nos dizeres de Ribeiro Jr, editor dos Hinos homéricos, os festivais eram um "misto de cerimônia religiosa, quermesse, de disputa esportiva e, naturalmente, de festival cívico ou religioso" (2010, p. 41). Ocorriam rituais como de purificação, refeições coletivas e as disputadíssimas competições. Quanto mais rica a pólis que patrocinava um festival, mais ela reafirmava seu prestígio na comunidade helênica, além de se beneficiar do comércio que movimentava na cidade. Evidentemente, esse era um momento em que a música se espalhava pela pólis.

Nas Olimpíadas só havia competições esportivas, mas os músicos trabalhavam para animar as festas e emitir sinais sonoros de variados tipos. Por esse motivo, instrumentos com mais volume e capacidade de penetração de som como o aulós, a trombeta sálpinx e os tímpanos devem ter sido os mais usados. Na passagem sobre o salto à distância no livro Sobre a ginástica Philostratos, autor do período romano fala da presença do aulós nas competições: "As regras que dizem respeito ao salto à distância (halma), como a mais difícil das competições, permitem ao saltador obter benefícios no ritmo pelo uso do aulós" (apud Miller, 2004, p. 67).

Os trompetistas começaram a concorrer em Olímpia a partir de 396 a.C. A avaliação era do volume de som e da duração da nota. Os outros concursos que completavam o circuito pan-helênico (período) tinham competições musicais: Pítia, em honra de Apolo; Ísthmia, em

${ }^{25}$ Isso teria sido contado por Heródoto. Há divergência a respeito de se o jovem Tucídides chorou porque percebeu a sua vocação de historiador ou de saudades de uma Grécia que não existia mais, ou, como me parece, pelas duas coisas (cf. Gagnebin, 1997, p.15-37). 
honra de Poseidon, e Neméa, em honra de Zeus. Esses festivais ocorreram ininterruptamente entre os séculos VI e III a.C., e além deles, havia os concursos regionais.

Max Weber constatou que "as relações entre a ratio musical e a vida musical pertencem às relações variadas de tensão historicamente mais importantes da música" (1995, p. 134-135). Nesse sentido, podemos dizer que os Jogos Pan-helênicos, movimentando a Hélade inteira assim como os também importantes festivais regionais foram grandes propulsores do desenvolvimento técnico dos instrumentos musicais.

Segundo Bélis, em Delos, "teria havido um catálogo impressionante de todos os vencedores nos concursos píticos, a partir da qual a lista completa foi compilada por Aristóteles e Calístenes: a inscrição, que comportava cerca de 24 mil caracteres foi completamente perdida" (1999, p. 143). O ideal de excelência fortalecia a identidade helênica das cidades. Uma característica marcante dos antigos gregos era o apreço por contendas de todo tipo e o apogeu desse traço cultural ocorria exatamente nesses jogos ou concursos. O fascínio pelos jogos está representado na Ilíada no momento em que Aquiles decide acrescentar uma sequência de disputas a uma cerimônia fúnebre em homenagem a Pátroclo (cf. Canto 23, vv. 257-70).

Do ponto de vista musical, o mais importante eram os Jogos Píticos, que aconteciam de oito em oito anos em Delfos. Eles homenageavam Apolo, mais especificamente a sua vitória sobre a serpente em Delfos; o prêmio era uma coroa de louros. A cidade foi um centro da difusão do culto dos deuses olímpicos e da poesia épica. A pítia, sacerdotisa que recebia a mensagem divina, tinha um especialista em versos à disposição para colocar a resposta em versos hexâmetros que entregava aos consulentes para que a memorizassem, em uma combinação de experiência poética e religiosa. É muito 
provável que houvesse alguma utilização de variações tonais na rítmica desss versos.

Inicialmente apenas os citaredos, ou seja, cantores - aedos que se acompanhavam na kithára participavam nas competições musicais dos Jogos Píticos. De acordo com Pausânias, a partir de 558 a.C. foi instituído um agon para citaristas, sem acompanhamento vocal, a chamada prova de psilokitharístes, solo de kithára sem o canto (cf. Bélis, 1988b, p. 242). As disputas com aulós foram incorporadas ao festival como uma novidade em 586-582 a.C. com concursos para aulêdos (instrumentista e cantor) e para aulêtas (cf. Mathiesen, 1999, nota 62 , p. 59). Aos poucos as competições chegaram a reunir todas as especialidades musicais da Antiguidade. Mas a kithára e o aulós serão durante muito tempo as estrelas dos concursos, fato que concorreu para seus avanços tecnológicos.

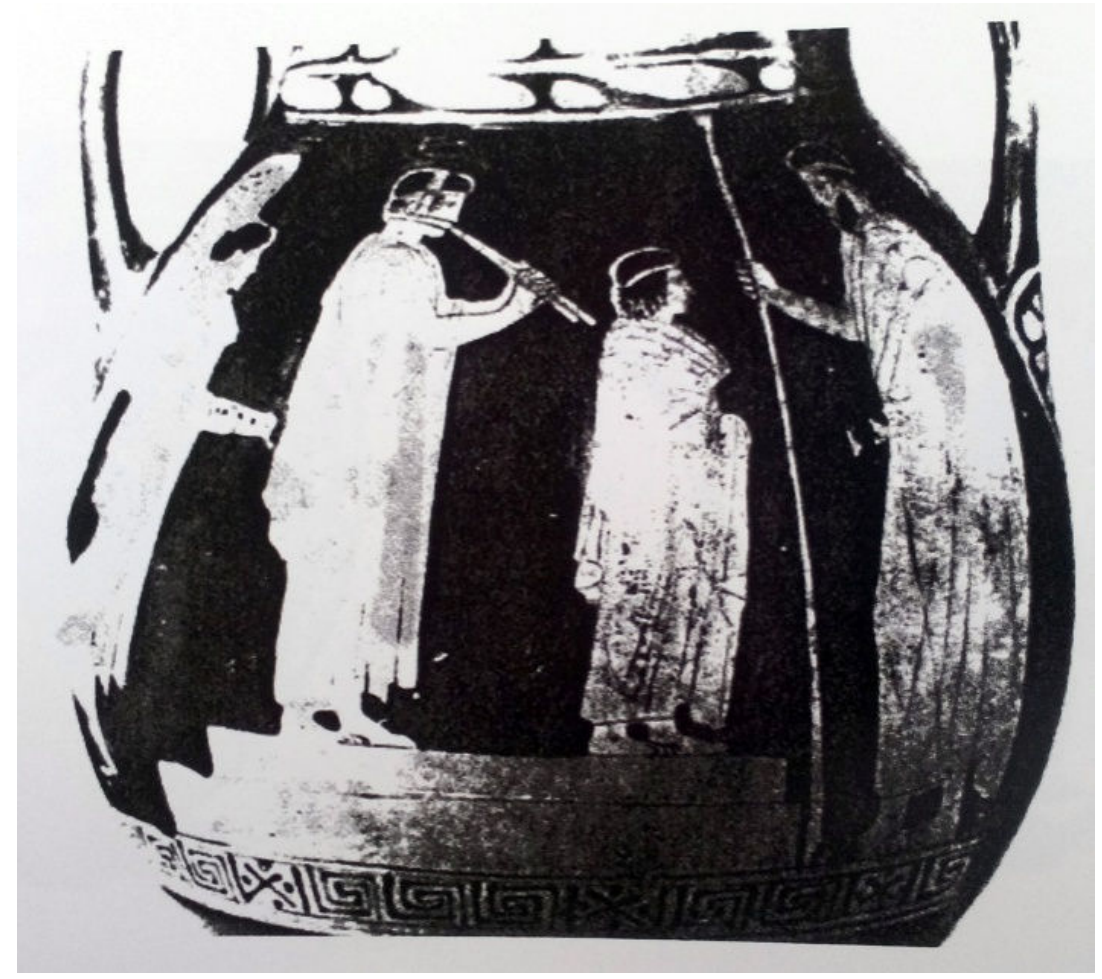

Fig. 60: Vaso ateniense vermelho mostra uma competição de aulodia, ou seja, duo de cantor e auleta, que aparece usando a phorbéia , c. 475 a 425 a.C. 


\subsection{O aulós e a sálpinx}

O aulós é um instrumento de longa tradição na cultura grega, como vimos, ele está presente nas representações das ilhas cicládicas e da cultura minoica. Ele não aparece em nenhuma imagem micênica, mas é mencionado duas vezes na Ilíada (Canto 10, v.13 e Canto 18, v.495), muito menos que os instrumentos de cordas, o que pode ser explicado, em parte, pelo fato de que as liras eram os instrumentos dos rapsodos.

Contudo, diferente da kithára, existem centenas de fragmentos de tubos de aulós descobertos em sítios arqueológicos, especialmente feitos de osso, bronze ou marfim. Eles estão datados de maneira precisa, permitindo uma avaliação bem mais segura a partir de seus vestígios que os instrumentos de cordas.

O aulós era popular em Esparta já no século VII a.C. quando a cidade era um dos centros mais dinâmicos da Hélade. Dois breves fragmentos do poeta lírico Alcmán, que viveu na cidade, fazem referência ao instrumento. Heródoto narra um aspecto curioso da aulética em Esparta: "Eles fazem como os egípcios: os arautos, os auletas e os cozinheiros, recebem essas téchnai de seus pais; o auleta é filho de auleta; o cozinheiro de cozinheiro e o arauto de arauto" (1985, p. 313). Vários expoentes da música no século VII a.C viveram em Esparta. Eles inovaram na criação dos nómoi, estruturas melódicas definidas para ocasiões específicas, rompendo provavelmente com a tradição musical da cidade. Alcmán dizia que conhecia os nómoi de todos os pássaros. Para Comotti, essa afirmação é um testemunho das "inovações no mélos tradicional, inovações que o poeta diz que foi o primeiro a introduzir, dizendo que imita a natureza em vez das autoridades anteriores" (1991, p. 18).

Apesar do aulós ser um instrumento presente desde longa data no espaço geográfico da Grécia era comum ele ser referido pelos gregos como não-helênico, muitas vezes originário da Frígia ou da 
Lídia. Na Ilíada, como vimos, ele é ouvido, ao longe, no acampamento dos troianos.

A kithára não possuía nenhuma história de origem mítica, ninguém reclamava ter sido seu inventor, já os prótoi eurétai do aulós variam entre o líbio Seirites, o sátiro frígio Marsyas e o auleta também frígio Olympus, músico a quem Aristóxeno confere a invenção do gênero enarmônico, do modo lídio e de alguns padrões rítmicos. Olympus podia até ser frígio, mas seu nome é helênico. No final do século IV a.C., a invenção do aulós é atribuída a divindades gregas como Apolo e Atena. Mesmo assim, Aristóxeno de Tarento classifica o aulós como um instrumento estrangeiro (cf. Bélis, 2015, p. 2).

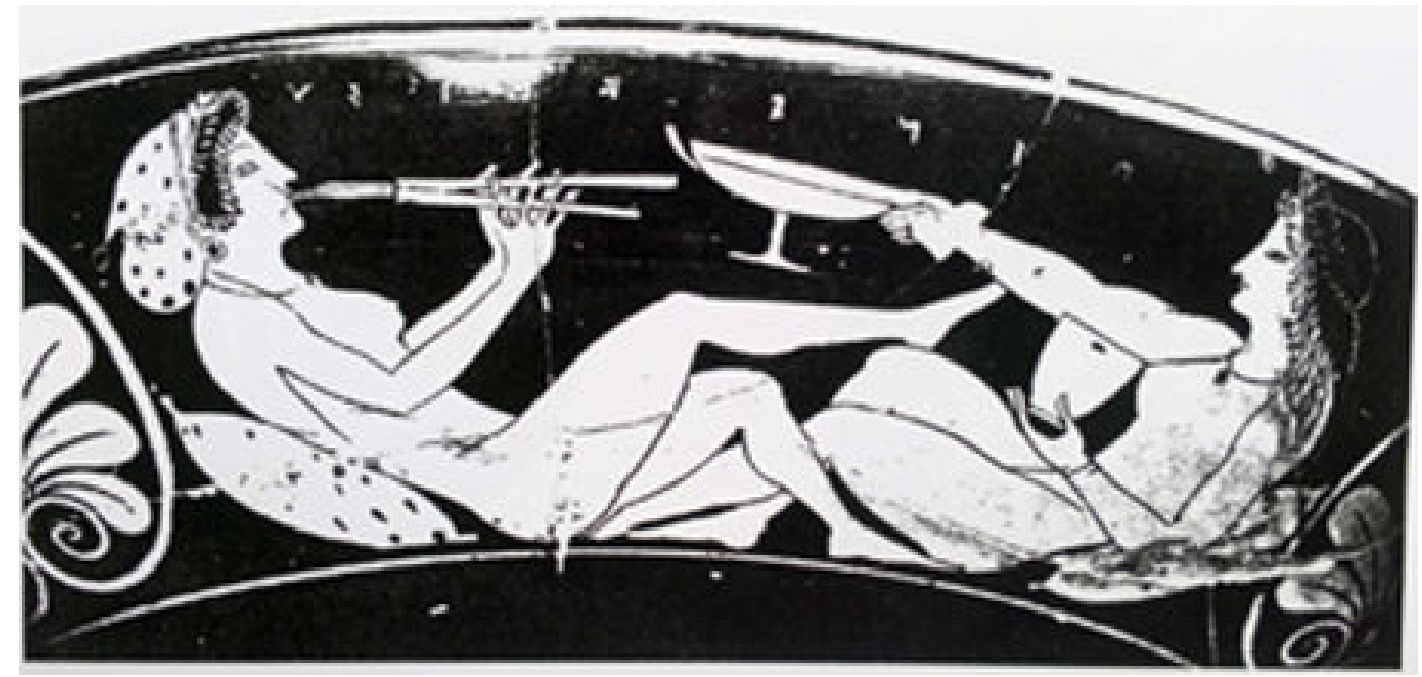

Fig.61: Aulétris em cena de banquete, c. 520-10 a.C.

Os tubos do aulós, duplos, eram cilíndricos e podiam ser feitos de madeira, junco, marfim, osso ou bronze. Nas extremidades superiores ficava uma espécie de bulbo onde eram encaixadas as palhetas duplas. O número de orifícios foi se modificando ao longo do tempo. Aristóxeno escreveu sobre aspectos técnicos do instrumento, mas só nos restaram fragmentos dessa literatura. Em Perí aulõn

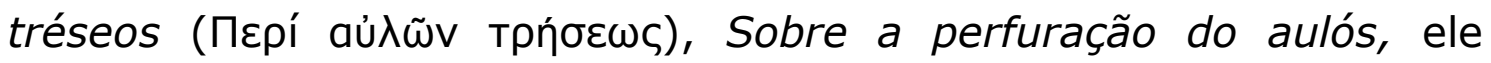
apresenta uma divisão do instrumento em quatro categorias, cobrindo 


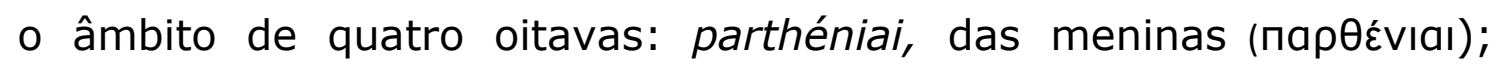
paidikói, dos meninos (паıঠıкóı); kithariáteroi, para tocar com a kithára,

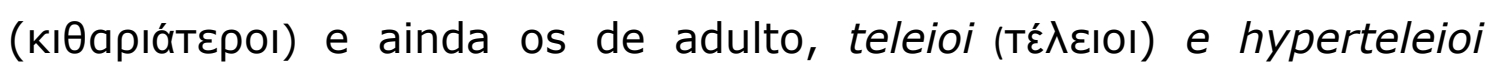

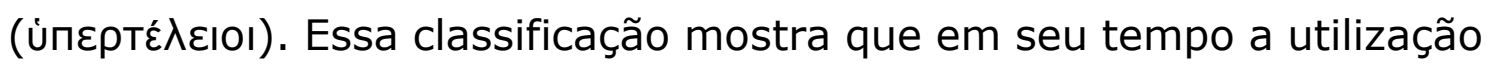
e fabricação do aulós na sociedade grega havia alcançado um nível de organização muito refinado. Além desses modelos descritos por Aristóxeno, era possível encontrar outras denominações para o aulós, uma indicação de que ele era muito popular. No século I a., haverá a diferenciação entre o aulós pítico (nuӨaú $\lambda$ n), adequado aos concursos musicais, e o choráulis (xopau $\lambda$ íc) que tocava com o coro na orquestra das apresentações teatrais.

Às vezes, os aulói eram chamados pelos nomes dos materiais de que eram feitos os tubos como lotós (tipo de madeira), kálamos (tipo de junco), tal como hoje chamamos de "pinho" o violão. $O$ artesão que trabalhava diretamente com a matéria prima era chamado de aulopoiós e o que fazia os orifícios, de aulotrýpes, sendo trýpesis a ação de fazer orifícios com um trýpanos.

O aulós tem menos partes a serem reunidas que a chélys, e poderia ser construído por um amador, contudo, os profissionais buscavam os aulopoiói para obterem instrumentos melhores do ponto de vista da qualidade e da durabilidade. Como diz Bélis, esses luthiers,

necessitavam, como na luteria moderna, um aprendizado de muitos anos: os textos antigos não fazem comentários a respeito, mas a beleza, a qualidade e a complexidade dos vestígios de instrumentos encontrados em sítios arqueológicos confirmam que esse era um trabalho de alta tecnicalidade, que requeria uma extrema habilidade manual (1998, p. 779).

Isso é confirmado por Burford quando comenta a respeito da qualidade do artesanato grego antigo em geral: 
A excelência do acabamento que muitos produtos apresentam nos resquícios de oficinas era uma espécie de façanha que ninguém que não houvesse sido bem treinado na profissão poderia ter, mesmo muito entusiasmado com a técnica. Essa excelência também não poderia ser aplicada apenas nos estágios finais. Ela tinha de ser aplicada na matéria prima desde o primeiro momento de sua manipulação. As fundações na plataforma do templo de Apolo em Delfos não eram menos acabadas e combinadas cuidadosamente que a sua superestrutura (1972, p. 69).

O aulopoiós tinha que conhecer e selecionar o material para fazer o corpo do instrumento, fosse ele osso, madeira ou marfim. De acordo com Plínio, em História natural, as espécies de madeiras escolhidas eram as de fibras densas, resistentes à umidade e os galhos selecionados eram os longos, grossos e retos. O corte era feito em estações do ano específicas e posteriormente passavam por tratamentos (cf. Bélis, 2015, p. 4). Bélis comenta que muitas vezes os aulói

eram fabricados de materiais caros, tal como o marfim e as madeiras raras, devendo ser importados, ou de metais mais ou menos preciosos (bronze fino, prata, oricalque), isso implica que os aulopoiói buscassem fornecedores, com exceção dos ossos que eram encontrados mais facilmente (1998, p. 784).

Com o material à disposição, o aulopoiós podia começar a trabalhar o tubo, bombýx (ò ßó $\beta \cup \xi$ ), de acordo com a variedade de aulós desejada. Os dois tubos do aulós helênico eram diferentes dos do frígio que tinha a campânula de chifre (kéras) encaixada em um dos tubos, alongando-o. Como vimos, o aulós frígio possuía um dispositivo,

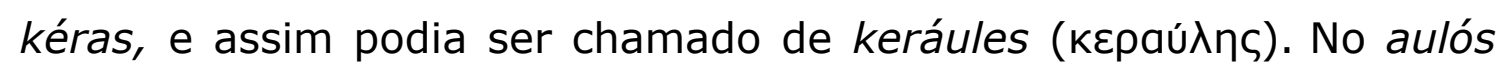
helênico, os tubos eram perfeitamente cilíndricos e do mesmo tamanho, apesar da variedade de modelos apresentada por Aristóxeno. 
Os ossos das pernas frontais de veados e asnos eram os preferidos pelos artesãos para a confeç̧ão do corpo do instrumento, o que é atestado por Plínio (cf. História Natural, Livro 11, cap. 87) e por Plutarco, que afirmava "que os artesãos tebanos haviam sido os primeiros a utilizarem esse tipo de osso, fazendo instrumentos mais sonoros" (apud Bélis, 2015, p. 4). Os vestígios arqueológicos confirmam essa utilização, assim como de outros materiais, sendo os vestígios de instrumentos de madeira, evidentemente, mais escassos. De acordo com Landels,

até meados do século $V$ a.C. a parte interna dos ossos era furada como um tubo cilíndrico exato, mas a parte externa era deixada ao natural, preservando as ranhuras deixadas no osso pelas fibras musculares. Então, com o aperfeiçoamento da técnica do torno, a parte externa era polida até se tornar um cilindro exato, polido e decorado com incisões lineares. Eventualmente, era dada às seções de osso uma camada fina de bronze ou prata (2000, p. 34).

É claro que, como dissemos, nem todos os ateliês possuíam, num mesmo momento, aparato técnico igual. Bélis observa que, em geral, havia uma ausência completa de padrão entre os instrumentos, inclusive porque muitos eram feitos sob encomenda dos próprios auletistas (cf. 1998, p. 781). Independentemente disso, cada um dos tubos do aulós era dividido em duas partes, fixadas uma à outra pelo sistema macho-fêmea de encaixe dos anéis, provavelmente entalhados na própria matéria prima. Os diâmetros variavam, mas em vestígios encontrados num ateliê em Delos, a média é de $10 \mathrm{~mm}$. Em outro modelo, correspondente ao hyperteléion descrito por Aristóxeno, o diâmetro é de $15 \mathrm{~mm}$.

Nas extremidades superiores dos tubos, eram encaixados um ou

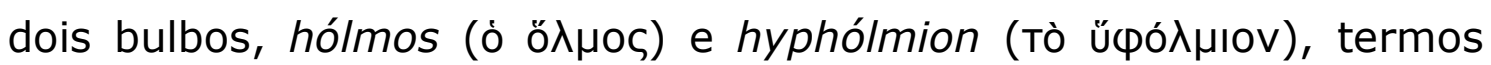
utilizados à cozinha, respectivamente, pilão e base de pilão, talvez por 
analogia a seu formato. A cavidade interna desses bulbos tinha 0 mesmo diâmetro do restante do tubo e, por isso, Landels diz que é "improvável que tivessem uma função acústica" (2000, p. 33). No bulbo ficavam as palhetas, duplas, pelas quais passava o sopro do auleta, dando a característica anasalada ao som.

As ferramentas para o trabalho com o tubo e os bulbos eram a serra, o torno e as substâncias abrasivas para o polimento; para abrir os furos era utilizada uma pequena pua, de acordo com Landels, "provavelmente girada por um arco" (2000, p. 34). O trabalho no torno, o entalhe e a abertura dos furos eram operações delicadas, em que podia ocorrer perda de material, o que encarecia ainda mais esses produtos. Se tivesse revestimento em metal ou adornos, o valor aumentava. Essa preocupação com a perda do trabalho está presente também na manufatura das palhetas, glóttides, uma atividade altamente especializada. Seus artífices, ao lado do aulotrýpes, detinham o segredo da afinação dos instrumentos.

Bélis comenta que, na maioria dos vestígios arqueológicos de instrumentos, os orifícios são "perfeitamente circulares, com as bordas aparadas impecavelmente e nenhum sinal de reparos ou erros" (2015, p. 5). Ainda segundo a autora, no período arcaico, cada tubo tinha de quatro a cinco orifícios, mas no começo do século $V$ a.C. existiam os auloi polytrétos, com muitos furos. Landels também observa a respeito dos orifícios que as bordas eram lixadas com uma inclinação para fora de modo que a parte almofadada dos dedos se adaptava perfeitamente e diz ainda ter percebido evidências de adaptações posteriores na parte de dentro do orifício de modo a corrigir problemas de afinação, ou seja, um trabalho minucioso (cf. 2000, p. 34).

No final da Metafísica, Aristóteles, debatendo a filosofia dos números pitagórica e reiterando que não considera que existam analogias que tinham como causa o número, dá uma pista do número de orifícios que tinha o aulós, no final do período clássico: "E eles dizem que são iguais aos intervalos entre as letras alfa e ômega e as notas 
mais graves e mais agudas no aulós" (1093b 2-3), ou seja, esse aulós teria 24 furos, algo que devia demandar uma habilidade bastante apurada do aulotrýpes e do auleta, assim como um sistema de chaveamento.

A seleção, colheita e preparo dos juncos (kálamos) para a fabricação das palhetas foi descrita em detalhes por Teofrasto na obra História das plantas, no capítulo sobre a flora do Lago Copais na Beócia, um dos centros de produção de palhetas na antiga Grécia. Estrabão cita outro local de onde vinha a matéria prima das palhetas: "os pântanos da região de Celenos, na Frígia, também proporcionavam canas de alta qualidade" (Strabo, Geografia xii, 8-15, apud Bélis, 2015, p. 5).

Segundo Teofrasto, os habitantes da região da Beócia afirmavam que os juncos apropriados para a manufatura de palhetas de auloi se desenvolviam quando o lago permanecia cheio por ao menos dois anos.

Eles dizem, e parecem estar certos, que quando o lago está profundo a cana cresce em comprimento e, se isso se mantem, ela se torna madura: a cana madura torna-se mais adequada para o zéugos ${ }^{26}$, e aquela em torno da qual a água não permanece, é mais adequada para o tubo (bómbyx).27

Dizem que ela difere das outras canas, em sentido geral, pelo seu crescimento luxuriante, sendo mais bem preenchida e mais carnuda, mais feminina na sua aparência. Além disso, sua folhagem é mais lisa e mais clara e sua flor no topo, menor que a das outras canas; algumas delas, que eles chamam de "palhetas-eunuco" não tem nenhuma flor no topo; são estas que dão origem às melhores zéuge ${ }^{28}$, embora

\footnotetext{
${ }^{26}$ A palavra é a mesma utilizada para o travessão superior das liras, pois significa uma concepção de par, de duas coisas juntas, no caso, as palhetas duplas do aulos.

${ }^{27} \mathrm{O}$ termo bombyx é utilizado tanto para o tubo quanto para a nota mais grave do instrumento gerada pelo tubo completamente fechado.

${ }^{28}$ Zeuge era o termo específico para as palhetas musicais.
} 
poucas conseguiam ser feitas corretamente na manufatura (Teofrasto, História das Plantas, apud Barker, 1989b, p.186-7).

Após a colheita, havia um processo rigoroso de armazenamento e tratamento dos juncos. Primeiro eles eram amontoados e deixados para secar durante alguns anos, mas no primeiro inverno eram embrulhados e deixados ao ar livre. Na primavera, as canas eram limpas, tiravam-Ihes a película e as deixavam para secar ao sol. No verão, começava o corte entre os nós e novamente essas partes iam para o sol. A partir daí, começava o processo de fabricação das palhetas: "as seções próximas dos pontos de crescimento (acima) produzem zéuge muito moles e as mais próximas às raízes, mais rígidas" (Teofrasto, História das Plantas, apud Barker, 1989b, p.187). Os pedaços de cana eram divididos ao meio no sentido longitudinal, formando dois lados, simétricos, que se encaixavam perfeitamente, formando a palheta dupla. De acordo com Bélis,

(...) cada lâmina era então dobrada na metade, dividida e as extremidades eram presas por uma linha enrolada; a parte vibrante final era chamada de boca (stóma) $(2015$, p. 6).

Plínio também descreve as canas da Beócia, propícias à fabricação de palhetas de aulói. O relato segue o de Teofrasto, mas Plinio diz que não pode deixar de comentar sua admiração pelo "maravilhoso cuidado com que os antigos tinham com esses instrumentos, uma coisa que, em alguma medida, pede uma apologia da sua manufatura em relação à preferência atual pela prata" (História Natural, Livro 16, cap. 60).

Plínio relata ainda que até a época em que vivia o auleta Antigênides, quando a prática do aulós era mais simples, as plantas eram colhidas no verão e demoravam alguns anos para estarem prontas para fazer as modulações preferidas do gosto daqueles tempos, mas quando a música se tornou mais variada, as palhetas 
precisaram ser mais abertas, e assim antecipou-se o período de corte. Desse modo, uma necessidade do auleta frente a seu público, modificou uma técnica talvez milenar de produção das palhetas. Essa nova técnica, plásis, permitia uma maior flexibilidade em efeitos como glissandos, trêmolos e vibratos. Landels considera que "o antigo processo envolvia colocar a palheta inteira na boca, deixando-a vibrar sem nenhum controle dos lábios" (2000, p. 29) e assim as palhetas seriam mais fechadas. No sistema desenvolvido após o tempo de Antigênides, as palhetas eram mais abertas e colocadas entre os dentes e os lábios e a técnica de produção do som ficou mais próxima do fagote e do oboé modernos (cf. Landels, 2000, p. 29). Esse método também possibilita um controle maior da afinação e da dinâmica.

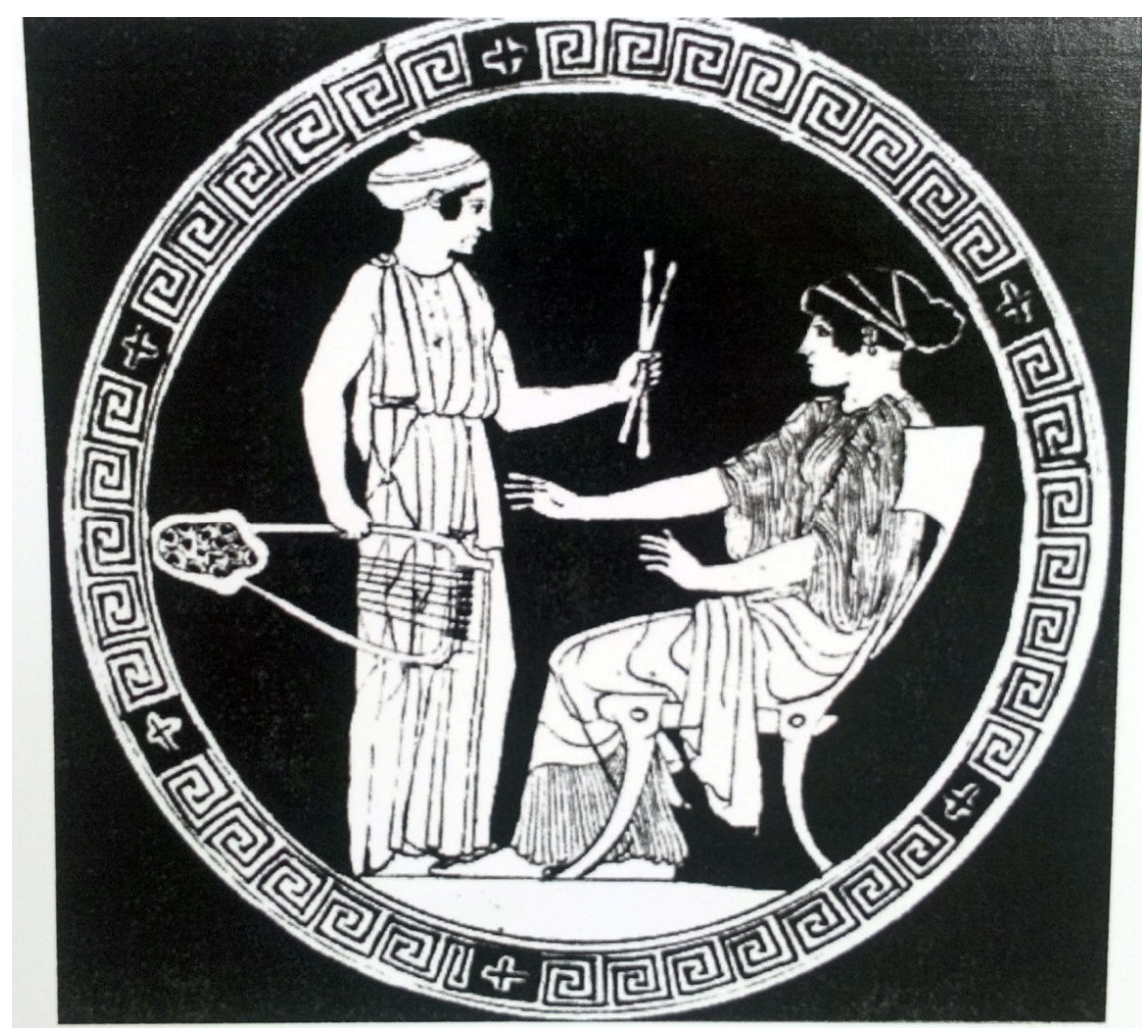

Fig. 62: Interior de uma kylix mostra duas mulheres, uma sentada em um klismoi e a outra segurando um bárbitos com uma mão e com a outra estendendo o aulós para a que está sentada, c. 460-50 a.C.

O domínio do aulós era algo que requeria muitos anos de prática. Mesmo assim aconteciam problemas como a do auleta que teve uma 
das palhetas soltas e ela ficou presa no seu palato, obrigando o músico a seguir soprando os tubos como se fossem de uma sýrinx, seguindo desse modo a execução até o fim (cf. Bélis, 1986c, p. 211-12).

Com a ampliação das possibilidades técnicas, o aulós foi ganhando sistemas de chaveamentos cada vez mais sofisticados como as kérata, dispositivos feitos de chifre, que foram interpretados por Bélis como um mecanismo que permitia ao músico fechar orifícios com uma alavanca e as syríngues, que teriam a função de produzir oitavas; muitas dúvidas ainda cercam o funcionamento exato desses mecanismos: teriam sido eles peças de metal deslizantes que o músico controlava por meio de chaves? Permitiriam a produção de uma oitava superior mantendo-se a mesma digitação da oitava inferior? Pelo fato do aulós ser cilíndrico e sua emissão sonora ser produzida pela palheta dupla vibrante, o registro agudo do instrumento produziria uma $12^{a}$ (quinta+oitava) e não uma oitava. Landels diz ainda que Aristóxeno utilizava o termo syrittein, "significando 'tocar no regsitro agudo', em contraposição a aulein 'tocar no registro normal'" (cf. 2000, p. 39).

Mas outro dispositivo técnico de performance utilizado pelos

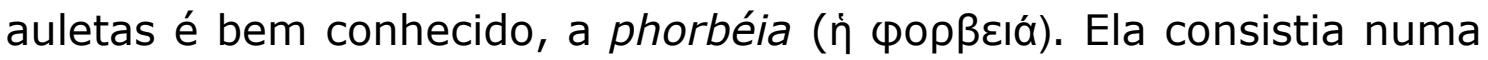
faixa de couro, que ficava em volta da face do músico, presa atrás da cabeça por dois anéis. A faixa tampava a boca do músico e prendia suas bochechas, e outra correia passava por cima da sua cabeça. $\mathrm{Na}$ parte da boca, a faixa de couro tinha dois orifícios por onde entravam as duas palhetas do aulós. 


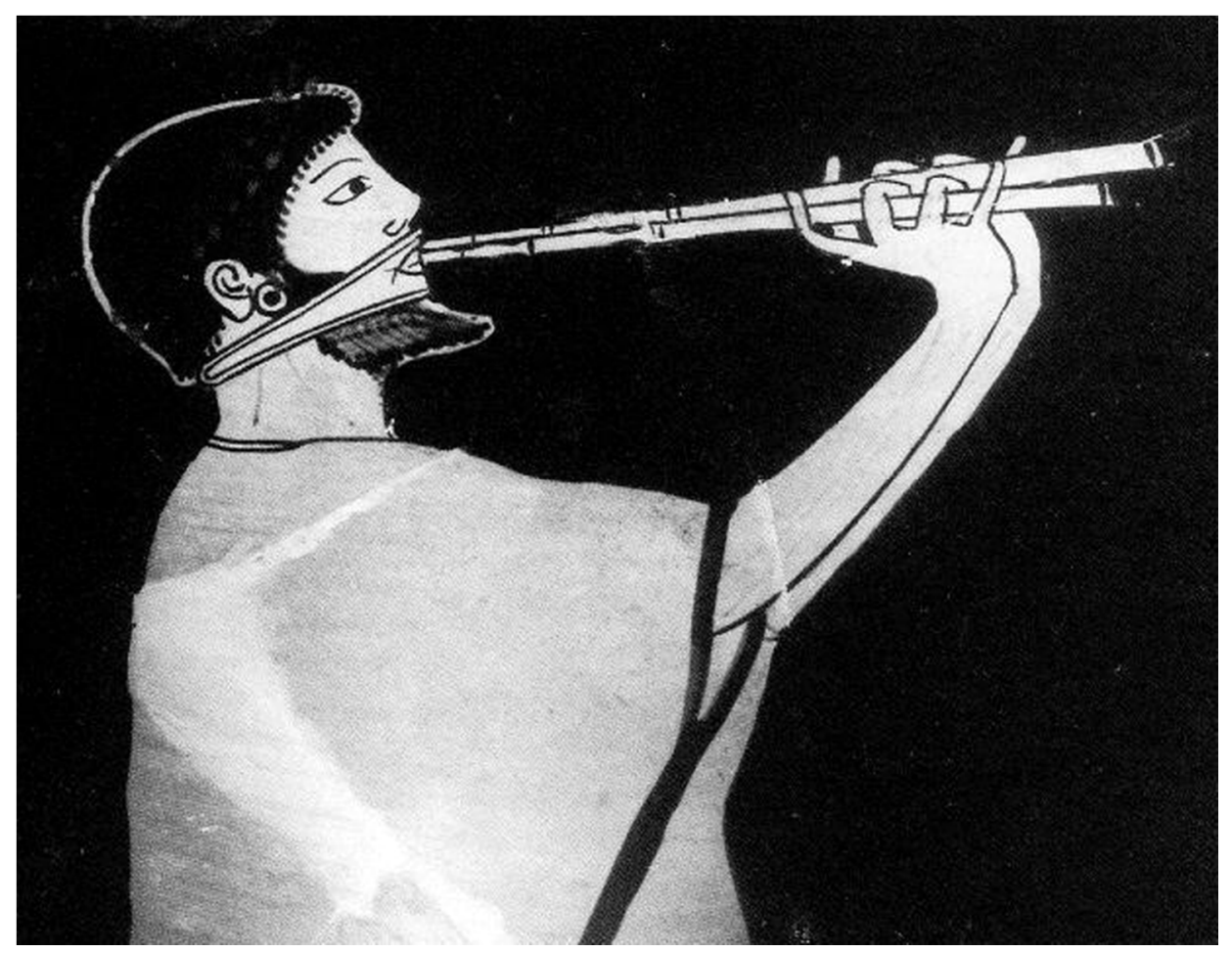

Fig. 63: Cerâmica vermelha ateniense mostra auleta com a phorbéia sobre os lábios. Notase que ele não infla nem mesmo as bochechas.

Alguns autores dizem que a função da phorbéia, capistrum entre os romanos, era não deixar transparecer as caretas do músico ao tocar o instrumento. De fato, as expressões faciais dos auletistas eram julgadas nos concursos. Mas em oposição a isso está o fato, segundo Bélis, dos músicos do trompete sálpinx também utilizarem a phorbéia em algumas circunstâncias, e eles não participavam de concursos propriamente musicais, em que as expressões faciais fossem avaliadas (cf. 1986c, p. 217). Os trompetistas concorreram apenas a partir do início do século IV a.C. das competições em Olímpia e só o volume de som e sua duração eram avaliadas.

A phorbéia pode estar relacionada à proteção dos lábios, para evitar o seu rompimento por conta da força necessária para fazer vibrar as palhetas. Mas, mais do que isso, as faixas tinham por objetivo impedir os lábios de vibrarem de modo descontrolado, evitando a emissão de sons descuidados pelos auletistas, chamados sarcasticamente de krázdein (kpá̧દıv), guinchar, ou chenízdein, 
(Xクví̧દıv) literalmente quando o aulós emitia o som anasalado de um pássaro.

Portanto, a phorbéia evitava sons desagradáveis e poupava as bochechas de uma tensão muscular excessiva. Bélis propõe que, ao poupar os músculos faciais do músico em longas apresentações, "ela contribuía para produzir uma emissão sonora de melhor qualidade, mais fluida e contínua" (1986, p. 217). A pesquisadora constatou, experimentando uma phorbéia, que ela impede o músico de respirar pela boca e, assim, sugeriu que os auletistas tenham utilizado uma técnica similar à da respiração circular conhecida dos saxofonistas.

As extremidades dos tubos (as bordas do hyphólmion) ficam em contato com o couro, enquanto que as duas palhetas do aulós passam pelos furos nele e entram na boca. Os lábios se fecham o mais fortemente possível; como indica uma passagem de Denis de Halicarnasso e a escoliasta da décima segunda Pítica de Píndaro, é imperioso que seja assim se se deseja evitar os "tremores" como diz Denis, mas também para evitar que as que as palhetas se soltem, como aconteceu a Midas de Agrigento [que teve as palhetas coladas no seu palato]. O volume na cavidade de ar é controlado de algum modo pela phorbéia: o auleta inspira pelo nariz e reenvia o ar para a boca; suas bochechas se inflam, até que encontram as faixas de couro, que não podem mais se distender. Então, todo volume de ar suplementar é expulso pela boca, dentro do aulós, na medida em que ele não pode entrar mais dentro da cavidade bucal, repleta no seu limite máximo. Nessas condições, a emissão de ar é regularizada e se faz de maneira contínua, sem depender mais das inspiraçõesexpirações do músico (Bélis, 1986, p. 211-12).

Um som contínuo e de qualidade eram condições importantes para o aulós. Se houve uma tentativa de helenizar o aulós, é possível que a phorbéia tenha tido uma participação efetiva nesse processo. As inovações no aulós helênico impulsionaram as técnicas de luteria 
antiga e aos poucos ele se transformou num instrumento polychordon, ou seja, no qual era possível tocar em muitos modos, e direcionado à alta performance. O fato do aulós ser polychórdon era considerado problemático por Platão, pois desse modo as mudanças de éthoi seriam constantes. Esse termo pode ter vindo das harpas, instrumentos que por possuírem muitas cordas também podiam fazer muitas modulações.

Bélis diz que as oficinas podiam fabricar tanto o aulós quanto a sálpinx, mas é preciso lembrar que isso só seria possível se fossem salpíngues de osso. Se elas fossem inteiramente de bronze, as técnicas seriam bastante distintas, dadas as diferenças de manipulação de material, madeira, osso, ou marfim para o aulós e o metal para a sálpinx. Já o bocal da sálpinx era feito de osso e podia ser de fato ser fabricado numa oficina de aulós.

A sálpinx era um tubo comprido, estreito, em geral feito de bronze com bocal de osso que terminava numa campânula, kodón (ó

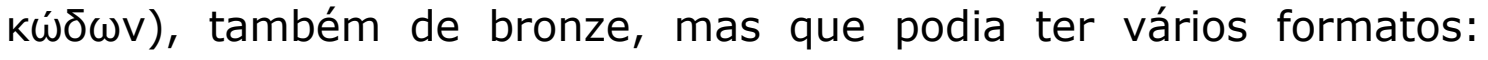
cônica, redonda e na forma de bulbo. O bocal era uma peça independente e tinha duas funções importantes: o suporte para os lábios, na medida em que é difícil manter a pressão do sopro direto num tubo de diâmetro reduzido e a obtenção de uma boa afinação e qualidade timbrística.

Xanthoulis estudou uma sálpinx do Museu de Belas Artes de Boston, feita de 13 pedaços de ossos encaixados com reforço de anéis de cobre. $O$ instrumento não foi submetido ao teste de carbono, pelo fato de que seria necessário danificar a peça, o que o Museu não estava disposto a fazer. Mas o pesquisador comparou essa sálpinx com fragmentos de outra trombeta encontrada em Lamia na Grécia central, datados entre 350 e 140 a.C., e encontrou similaridades entre os dois instrumentos (cf. 2006, p. 44). É possível que os anéis de ossos encontrados em Delos pudessem ter uma origem diferente da proposta 
por Bélis, em vez do material descartado do mandril que fixava um aulós, pedaços de salpíngues estariam dispersas pelo ateliê.

As salpíngues eram tocadas nas batalhas, em cerimônias e rituais, nos eventos esportivos e também em momentos de descontração. Elas tinham funções semelhantes às kérai, chifres, mas eram instrumentos bem mais sofisticados. Póllux, no Onomásticon, refere-se ao anúncio da trégua sagrada, talvez acompanhado do toque de salpinx:

A raça dos arautos

Tornada sagrada pelo deus Hermes

Proclamou silêncio durante as disputas

E nos ritos anunciou as libações

E a trégua, e anunciou os competidores (apud Xanthoulis, 2006, p. 39)

As referências literárias apontam a sálpinx como um instrumento de bocal, tal como um trompete moderno, mas em algumas representações em cerâmicas, o músico aparece utilizando a phorbéia, como um instrumento de palheta. Bélis analisou essas cerâmicas e constatou que a maioria é do final do século VI a.C., levando-a a considerar que no período arcaico teriam convivido dois modelos de salpíngues, a de palheta e a de bocal, sendo este último modelo adotado definitivamente a partir do final do século $V$ a.C. Mas Bélis apresenta outra evidência que contradiz que a sálpinx de palheta tenha desaparecido: dois instrumentos de bronze preservados em Pompeia, com palheta (1986, p. 217).

A sálpinx de palheta pode ter sido um instrumento intermediário, com a sonoridade brilhante do bronze e a nasalidade da palheta, mas nos combates dos gladiadores, em que sua presença é atestada, talvez ela fosse um instrumento mais complicado de tocar devido a seus múltiplos aparatos como as palhetas e a phorbéia. 
Apesar de haver referências no De audibilibus da utilização mais relaxada da sálpinx, ela era mais frequente nos chamados militares ou nas competições esportivas e, como já dissemos, foi o único instrumento musical a ser aceito em concursos nas Olimpíadas, a partir de 396 a.C. Os jurados preocupavam-se com o volume, potência do sopro e sua duração. Pólux cita Archias de Yvla como vencedor quatro vezes do concurso. Aglaisi Megakleous foi uma das poucas mulheres que venceram a disputa; como há relatos de ela ter participado de uma procissão em Alexandria - com uma máscara e um elmo na cabeça (cf.Xanthoulis, 2006, p. 40), ela era uma musicista do período helenístico.

Aristides Quintiliano, autor já do período romano, expôs em sua obra De musica, o léxico militar da sálpinx, provavelmente utilizado pelos exércitos romanos: exorméticon, atacar; paraléustikon para alguma ação específica pré-combinada; anaklítikon, retirada e anapáusticon, descansar (apud Barker, 1989b, p. 62). Segundo o autor, esses toques eram diferentes entre os exércitos, para que os inimigos não se antecipassem. Isso me fez lembrar da anedota contada por Marcel Mauss em sua conferência sobre as técnicas do corpo, na qual relatou uma experiência da primeira guerra que ele mesmo viveu relacionada à marcha.

O regimento de Worcester, tendo feito proezas consideráveis durante a batalha do Aisne, ao lado da infantaria francesa, pediu a autorização real para ter toques de clarins e baterias francesas, uma banda de corneteiros e de tambores franceses. $O$ resultado foi pouco encorajador. Durante cerca de seis meses, nas ruas de Bailleul, muito tempo depois da batalha do Aisne, vi com frequência o seguinte espetáculo: o regimento conservara sua marcha inglesa e a ritmava à francesa. Tinha inclusive à frente da tropa um pequeno ajudante de infantaria francês que tocava corneta e marcava os passos melhor que os demais. O pobre regimento dos ingleses não conseguia desfilar (1934, p. 403). 
Mauss expõe essa anedota como exemplo de que "uma habilidade manual só se aprende lentamente. Toda técnica propriamente dita tem sua forma" (1934, p.403). Apesar de isso ser evidente no caso narrado acima, os toques e os ritmos têm de ser diferentes do dos inimigos para que os ataques não sejam reconhecidos e os exércitos e antecipem-se um em relação ao outro. Mas além disso, quanto mais complexa uma técnica mais lentamente o corpo a absorve. No caso da técnica de execução musical, o instrumento para ser tocado com maestria, deve tornar-se uma extensão do instrumentista e isso requer memória corporal e, mais especificamente, digital. O domínio completo do aulós helênico solicitava cerca de 15 anos de estudo, o que atesta a complexidade que o instrumento atingiu na cultura antiga grega.

Essa destreza na prática instrumental atingia seus pontos máximos nos concursos musicais. Cada um possuía um nómos próprio, ou seja, uma peça em que o executante exibia a sua téchne de execução e performance. No nómos pítico, ela era uma peça em quatro ou cinco partes com graus sucessivos de dificuldade, que por sua vez evocavam os episódios sucessivos do combate de Apolo com a serpente Python, que tentara impedir que Apolo erguesse o seu santuário em Delfos.

As partes do nómos pítico eram a) introdução instrumental; b) provocação da serpente; c) combate no ritmo iâmbico (aqui o músico deveria imitar os sons da serpente e os movimentos da serpente e de Apolo); d) o triunfo de Apolo e e) a dança da vitória. Era uma música nascida de um estímulo extramusical, de imitação gestual e o pequeno espaço do pódio (béma) onde os executantes se apresentavam limitava os gestos voltando a atenção completa para a música e as expressões faciais dos intérpretes, que também eram consideradas no julgamento. 


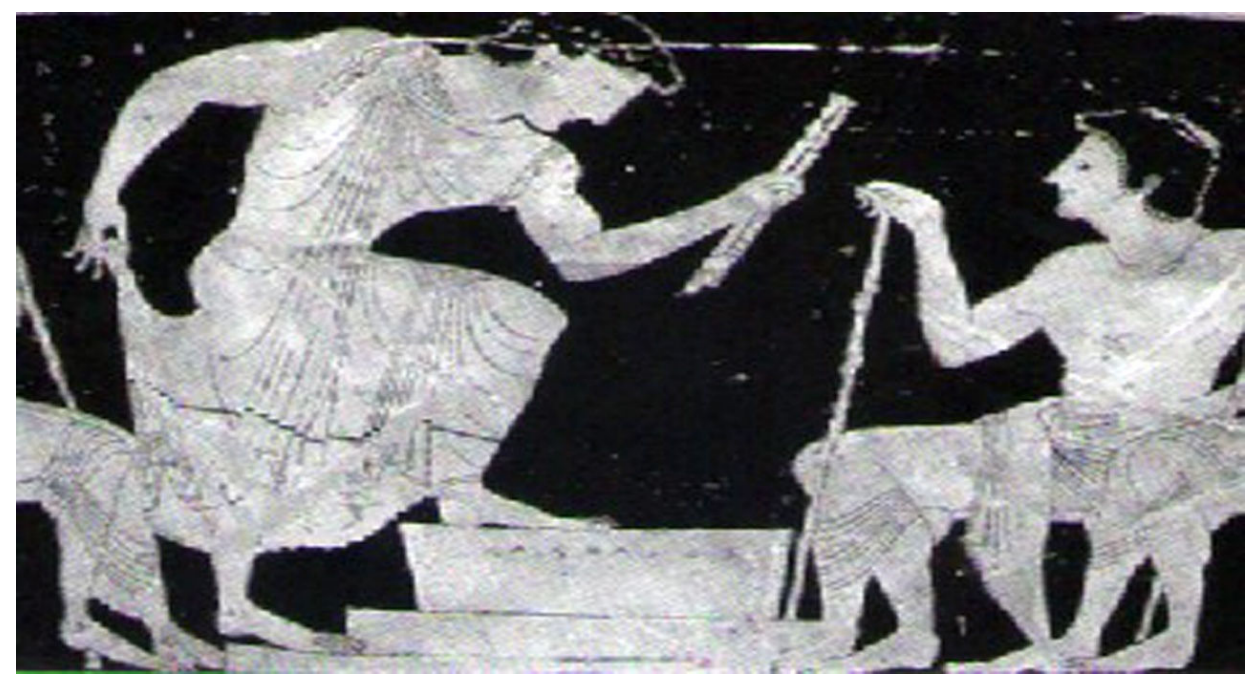

Fig. 64: Detalhe de uma cratera: o auleta Mélas subindo na béma, em um concurso em frente de seus juízes, c. 510 a.C.

O nómos pítico era aulético, adequado à performance dos auletas. Pela característica do aulós, a aulética se difundiu mais rapidamente como música instrumental - é impossível cantar e tocar aulós ao mesmo tempo - e um lugar privilegiado para isso evidentemente foram os Jogos Píticos. Todo o gestual de tocar o aulós, instrumento grande e provavelmente pesado, acentuava a carga dramática do mito.

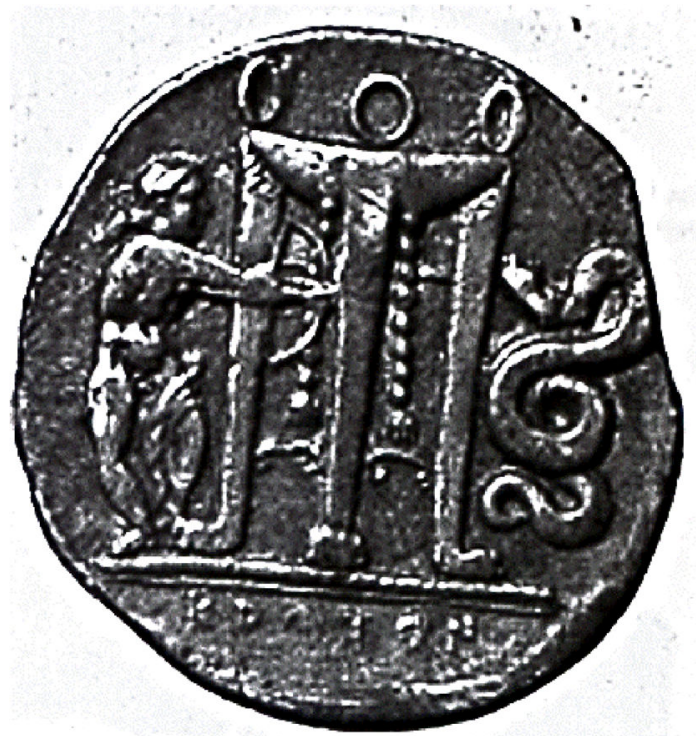

Fig.65: Face de moeda antiga grega, com a trípoda e o combate de Apolo contra a serpente em Delfos gravados. 


\subsection{Percussões e outros dispositivos}

Se a quantidade de representações nas cerâmicas fosse um critério para julgarmos qual o instrumento de percussão seria o mais querido dos gregos, as grandes castanholas chamadas krótala seriam as vencedoras. $\mathrm{O}$ instrumento aparece em inúmeras cenas de dança e também com o aulós, combinação gestual e sonora que devia ser bastante apreciada.

As krótala requeriam o trabalho de entalhe, torneamento e polimento da madeira, da qual não temos informações sobre a espécie mais utilizada para a construção, mas devia ser uma madeira leve e de boa qualidade sonora, como o ipê brasileiro, na medida em que ela é a única fonte geradora do som do instrumento.

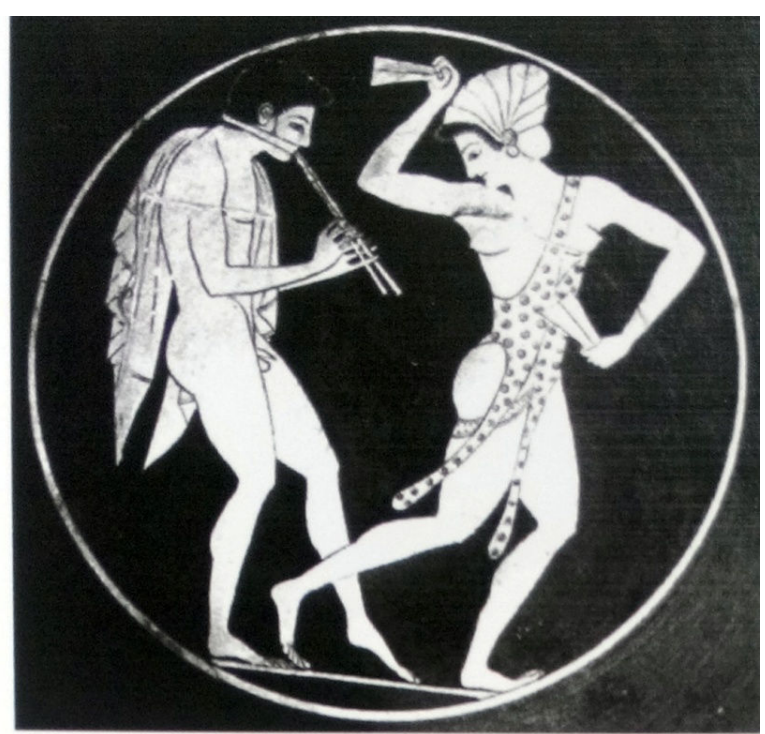

Fig. 66: Detalhe de kylix: Dançarina musicista com krótala e auleta usando phorbéia. Assinado por Epicteto, c. 510-500 a.C. 


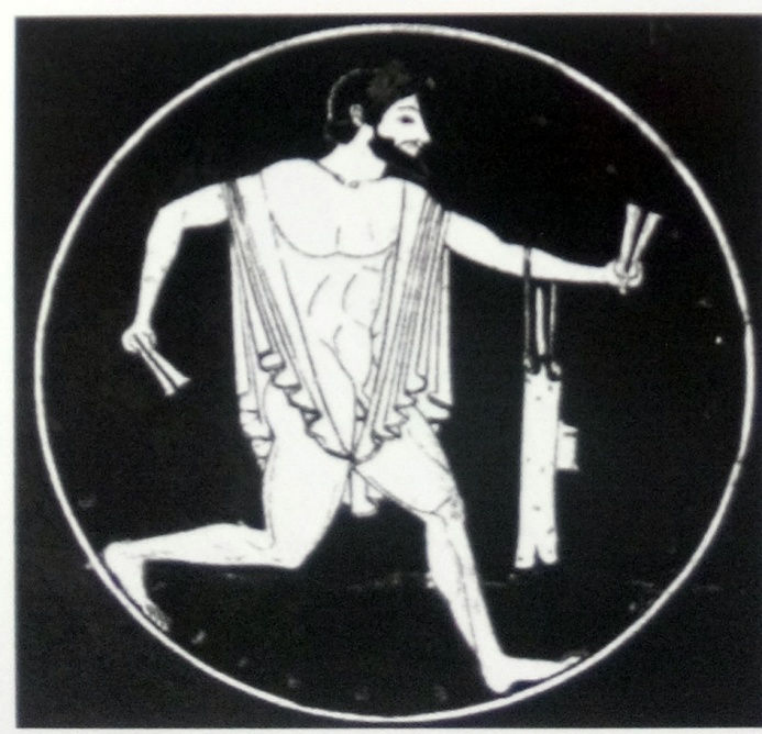

Fig. 67: Músico com krótala. No braço esquerdo, a sybéne, estojo do aulós; presa nela, a glottokomeion, caixinha para carregar as palhetas. Assinado pelo oleiro Kakrylion, c. 51510 a.C.

Os címbalos, kymbala (Tá kú $\beta a \lambda a$ ), também são recorrentes. Eles podiam ser de madeira com uma chapa de metal em seu interior ou inteiramente de bronze. A fabricação de címbalos era muito desenvolvida na cultura chinesa do mesmo período e o antigo processo de fabricação seguia os seguintes passos: fusão do bloco de metal em alta temperatura e passagem pela têmpera para dar o formato aproximado do instrumento, em seguida, esfriamento com o malho para endurecer o metal, e depois o trabalho no torno para reduzir a sua espessura, quanto mais fino, mais refinado o timbre do instrumento. Para finalizar, mais uma sessão de malho a frio. $O$ trabalho necessitava de um artífice de muita habilidade manual e aquecer e resfriar o bronze, como já dissemos, era extenuante. 


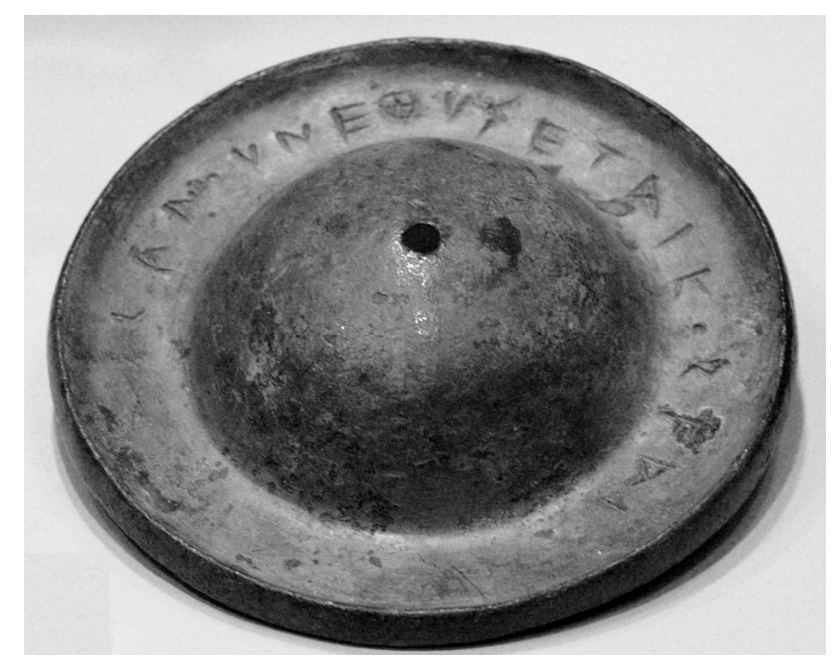

Fig. 68: Kýmbalon antigo de bronze.

Tanto as kýmbala quanto as krótala (тó крóтa $\lambda a$ ) requerem muita habilidade de dedos e mãos para tocá-los. A técnica de execução das krótala, não deve ter sido muito diferente das castanholas, exceto que pelas imagens, elas parecem ser bem maiores, então algumas diferenças devem ter existido, das quais não temos muito conhecimento. Não também não temos muitas informações sobre os

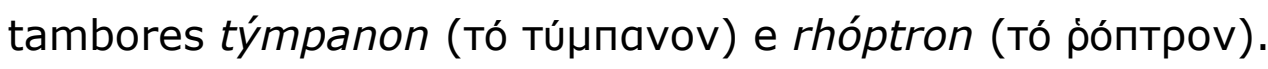

Os instrumentos de percussão tinham 0 papel de acompanhamento das manifestações de dança, musicais ou teatrais, com presença marcante também nos rituais. O rhómbos (ò pó $\mu \beta \circ$ ) era um zunidor de madeira, que, preso por um cordão, ao ser girado, produzia uma sonoridade grave, de ventania, e aparecia nos cultos de Deméter e depois de Cibele em Roma, assim como a kýmbala, o týmpanon e o aulós (Fig. 69). 


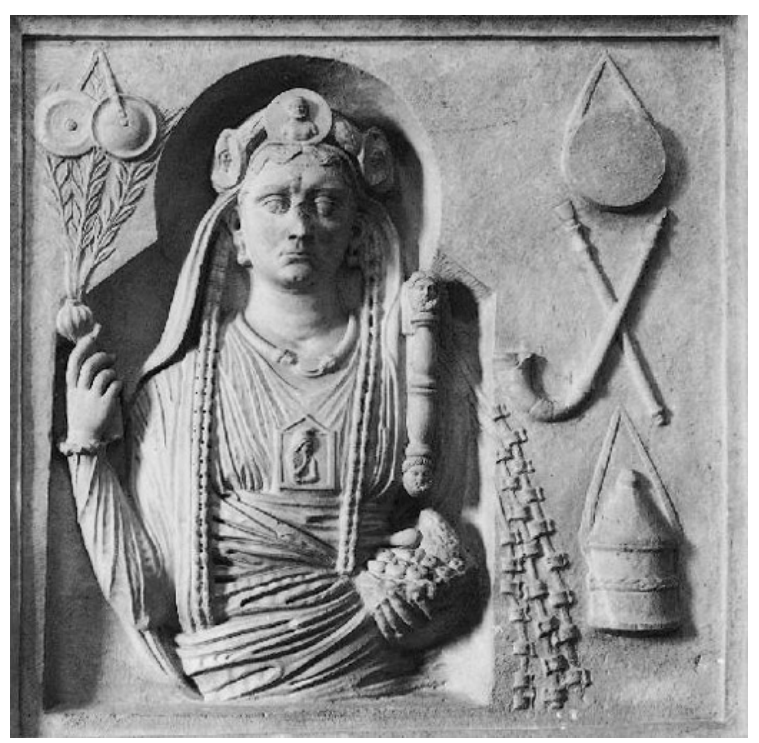

Fig. 69: Sacerdotisa de Cibele (Deméter) com os instrumentos relacionados: à esquerda, acima, kymbala; à direita, acima, tambor tímpano; no meio, um aulós frígio. Relevo romano do século II d.C.

A chapa de metal bronte (ì ßpovtì) reproduzia o som do trovão e era utilizado nos festivais teatrais como as Grandes Dionisíacas de Atenas. Outro artefato, as kroupézdai (ai kpounḉaı), consistia num pequeno mecanismo na forma de um tamanco com sola dupla, com uma abertura entre elas, às vezes preenchida com um kýmbalon de metal. Ele era usado pelos auletas para marcar o ritmo. As kroupézdai fizeram muito sucesso em Roma, com o nome de scabellum; a cidade tinha predileção por grandes combinações de instrumentos e os scabellari eram espécies de maestros, que contavam inclusive com uma associação organizada (cf. Bélis, 1988b, p. 230). O termo kroupézai referia-se também aos pedaços de madeira utilizados para amassar azeitonas para fazer azeite de oliva (cf. Bélis, 1988a, p.3289). 


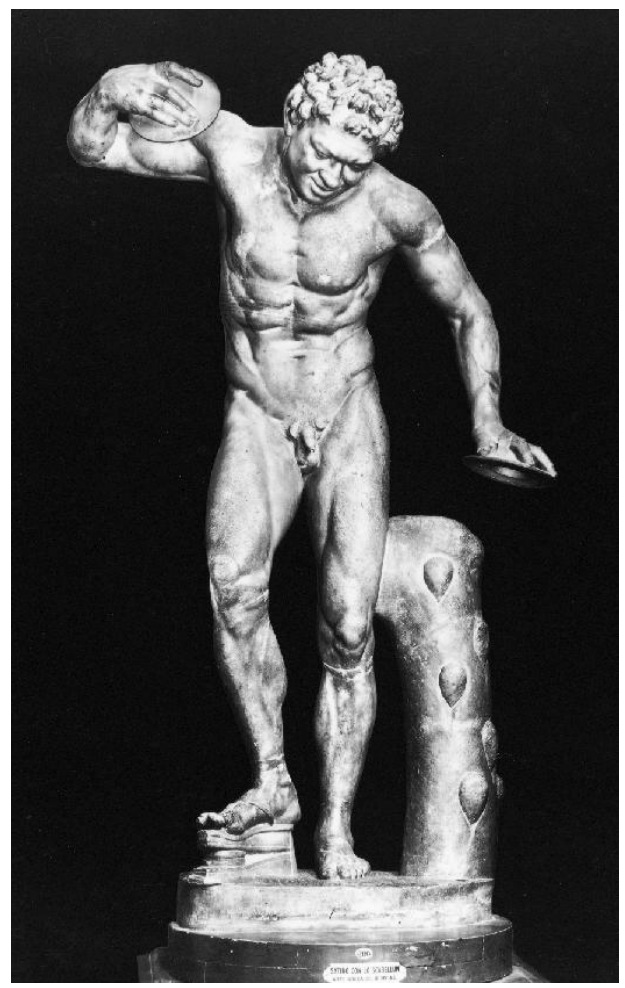

Fig. 70: Sátiro com kroupézai (em Roma, scabellum) do grupo "Convite à dança", período helenístico (cf. Bélis, 1988a, p. 324).

Os instrumentos musicais também demandavam a manufatura de dispositivos como o plectro, a phorbéia, as cordas, o suporte para a kithára, telamón, os kollópes e as glottídes. Além disso, havia os componentes estéticos da performance como as vestimentas luxuosas

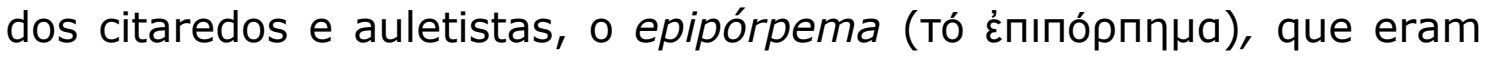

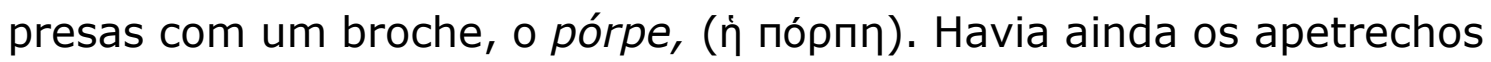

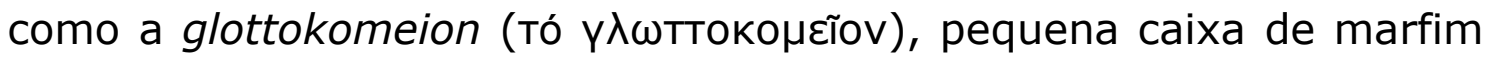
onde eram guardadas cuidadosamente as palhetas; a sybéne ( $\dot{n}$

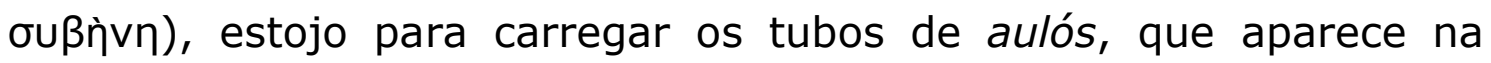
iconografia como sendo feito de pele de leopardo ou outro animal pintado. Tudo isso, e muito mais, devia ser vendido pelos artesãos e mercadores, especialmente durante o período dos concursos e festivais. 


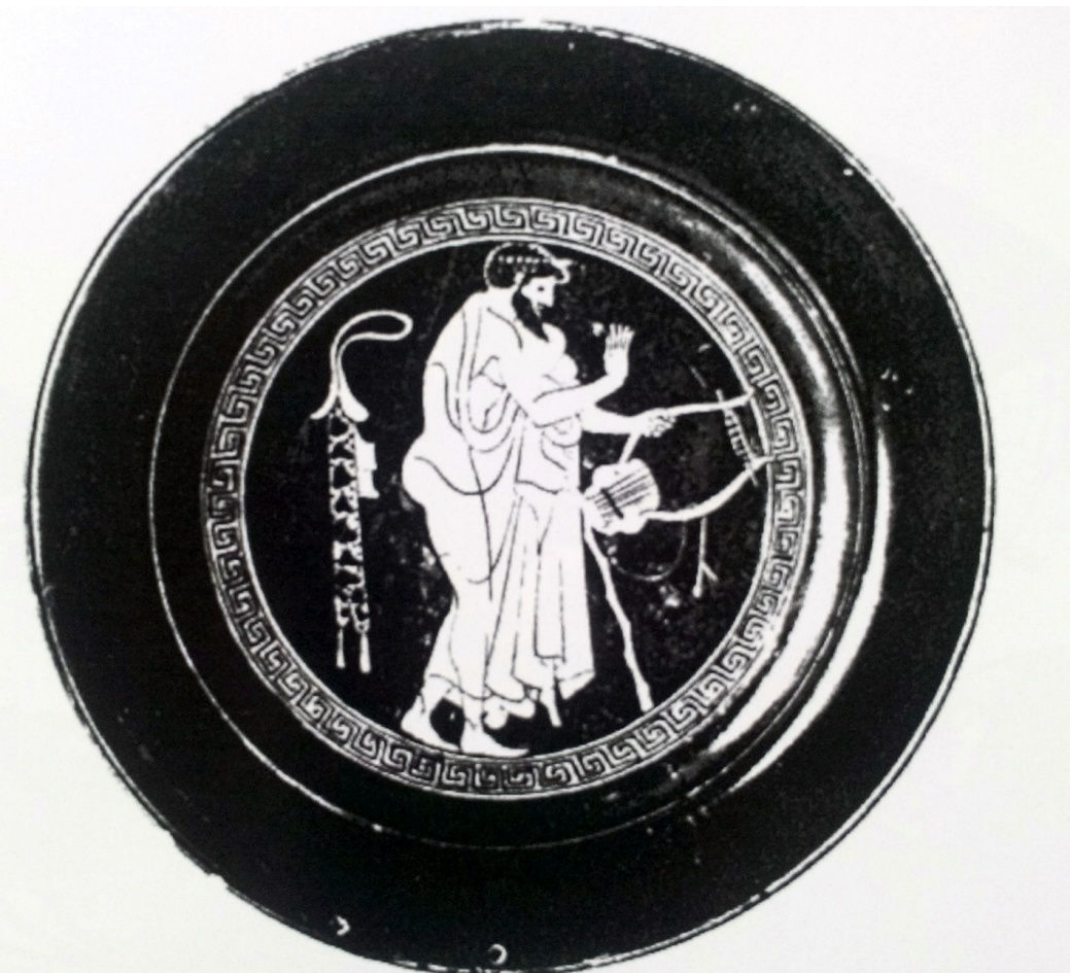

Fig. 71: Músico com uma lira. Na parede, uma grande sybéne, estojo para guardar o aulós, possivelmente feito de pele de pantera ou outro felino.

Os festivais regionais também tinham a sua importância. A presença de músicos como Terpandro e Alcmán havia dado projeção ao concurso de Karnéia em Esparta. Corinto teve nomes como Árion, que foi trazido de Lesbos para a corte de Periandro; as ilhas gregas, como Lesbos e Delos, foram igualmente significativas no ambiente musical grego. Atenas chega à cena cultural um pouco mais tarde, no século VI a.C. Em 566 a.C. foram instituídas as Panatenéias, concursos em homenagem à deusa Atena que, de cinco em cinco anos, promoviam competições de ginástica, hipismo e música.

Pisístrato governou Atenas entre 546 e 527 a.C. e, sob seu governo, um número cada vez maior de cidadãos adquiriu o direito de intervir na política. Nesse contexto, por volta de 534 a.C. foram instituídas as Grandes Dionisíacas. Elas ocorriam em março, durante seis dias, com competições de coros trágicos, cômicos, satíricos e ditirâmbicos. Nos ditirambos, apresentavam-se os coros de cidadãos, homens e meninos que memorizavam extensos poemas que podiam 
ter mais de cem versos; eles eram acompanhados de um auletista profissional. O aulós, instrumento já presente em situações de carga dramática na cultura grega, como as lamentações, os cultos de Deméter e o nómos pítico, foi o instrumento musical mais relevante para o gênero trágico que se desenvolveu a partir do século VI. Como diz Wilson

O poder musical e tonal [leia-se timbrístico] do aulós para evocar registros abaixo do canto do coro, todo masculino, será vital em um gênero em que a música de lamento é a forma dominante. Mais tarde, no século $V$ as inovações técnicas no instrumento, que mencionei, significou que poderiam ser reproduzidos no aulós, ruídos, mesmo mecânicos, assim como sons da natureza selvagem: nós ouvimos falar de tempestades, o ruído de eixos, cordas e roldanas e os gritos de mulheres no trabalho de parto (2008, p. 185).

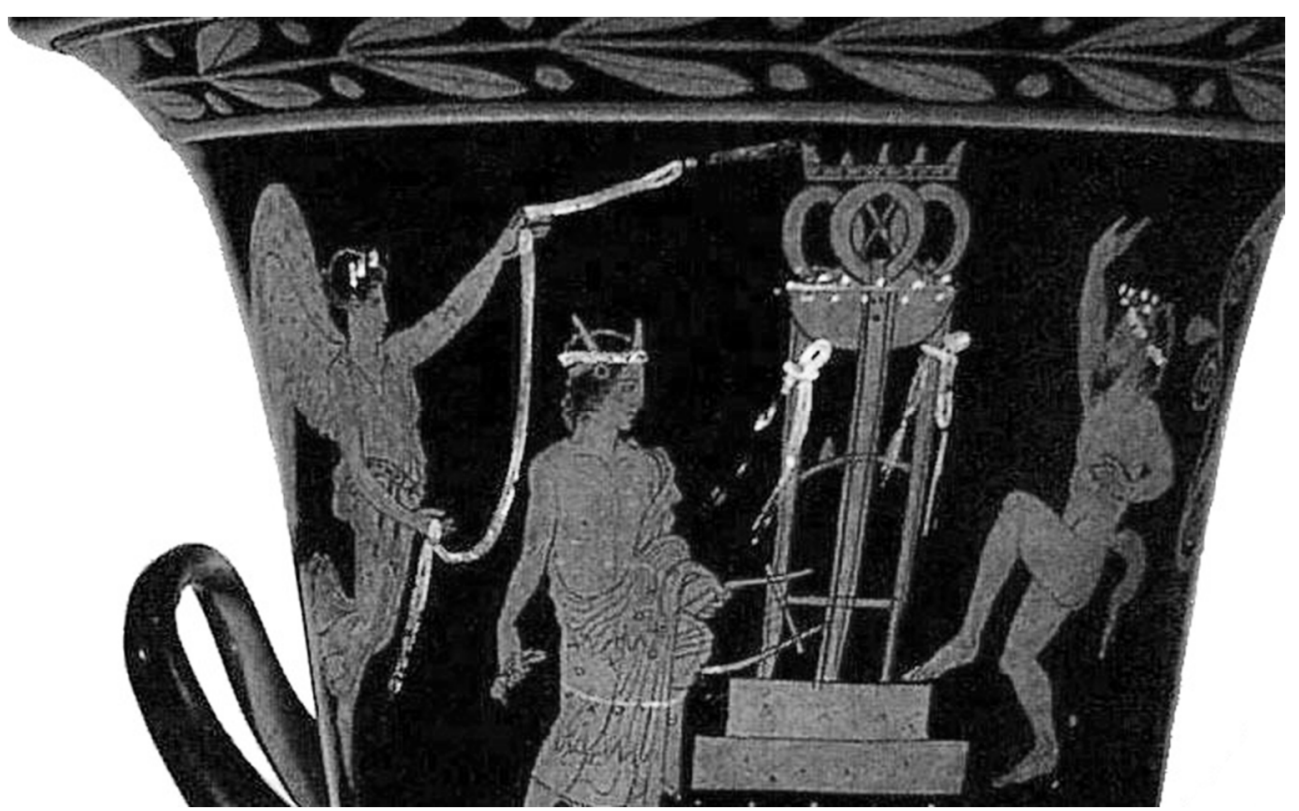

Fig. 72: Cerâmica ateniense vermelha, com cena de teatro, c.450-400 a.C.

As imitações exageradas dos auletas foram repetidamente motivo de crítica por parte de Platão. Aristóteles, na Poética, faz poucas referências à parte da música na tragédia, comparativamente ao papel 
fundamental que tinha, mas não deixa de criticar o comportamento excessivo, a seu ver, dos auletas (1461b 30-2). Aristóxeno tratou da tragédia em obras como Sobre os poetas trágicos e também em Sobre o aulós, embora tenhamos poucas referências delas e ainda menos fragmentos.

A tragédia era um espetáculo ao ar livre que combinava atuação, música e coreografia. O coro cantava no início e no fim do espetáculo e era também o responsável pelo entrelaçamento das cenas de canto e dança. Em alguns momentos, o coro estabelecia diálogos musicais com os atores, que também cantavam em solos ou em duetos. O aulós era o instrumento principal, mas existem relatos da presença da kithára, como na apresentação em que Sófocles, que era grande citarista, a executou, fazendo o papel de Thamirys, na tragédia de mesmo nome, de sua autoria, baseada na história desse citarista trácio (cf. Mathiesen, 1999, p. 259).

\subsection{Artefatos-modelos: a harpa e a sýrinx}

As harpas não foram protagonistas no universo altamente competitivo dos concursos musicais, apesar de haver referências à participação desses instrumentos nos jogos. No período clássico, elas aparecem reservadas ao ambiente doméstico e ligadas às mulheres, chamadas de psaltríai. Teria havido um arrefecimento das experimentações com esse tipo de instrumento nas oficinas?

As harpas receberam denominações variadas, mas independente do nome que tinham, apresentavam um componente bastante diferente das liras: as cordas graduadas. Um número grande de cordas não poderia produzir diferenças tonais apenas com espessura e tensão. A disposição das cordas permitia ao músico ver as diferenças entre os tons de maneira organizada e escalonada. A teoria musical pitagórica pode ter observado essa característica, uma vez que seu argumento 
principal acerca das afinações dos tons está baseada nas medidas dos comprimentos das cordas.

De acordo com Mathiesen, cientistas musicais do século VI a.C. estiveram associados a alguns tipos de harpas (1999, p. 270). Um deles teria sido Epígono de Sycion que criou um instrumento de 40 cordas, o epigóneon (cf. Ateneu, 183 c), tocado com os dedos diretamente nas cordas, sem o plectro. Ateneu diz que, em seu tempo, o instrumento havia sido remodelado como um psaltério vertical. Rios diz que Porfírio no Comentário à Harmônica de Ptolomeu cita as escolas de Epígono, Damon, Eratócles e Agenor como anteriores à escola de Aristóxeno. Lasos teria escrito uma obra didática e Epígono teria construído o epigoneion como um instrumento de estudo (cf. Rios, 1954 , p. 7, n. 1 e 2).

Segundo Maas e Snyder, não existem registros iconográficos de harpas do período arcaico: "após o período cicládico, as harpas não reaparecem na arte grega até o final do século V a.C." (1989, p. 40). Mas elas surgem com frequência na poesia lírica de Anacreonte, Safo e Alcmán. Há muita controvérsia a respeito dos formatos e número de cordas das harpas, que podiam receber nomes como pektís, magadis ou trigona, mas das quais não temos suas representações precisas.

Em uma ânfora de cerca de 430 a.C. vemos uma harpa com os fixadores/afinadores bem nítidos, no modelo em que a corda mais grave está no lugar em que ficaria a corda de um arco de caça. A harpista toca o instrumento sem plectro, diretamente com os dedos. Essa é uma harpa de ângulo, diferente da harpa fechada nos três lados, a trígonon. 


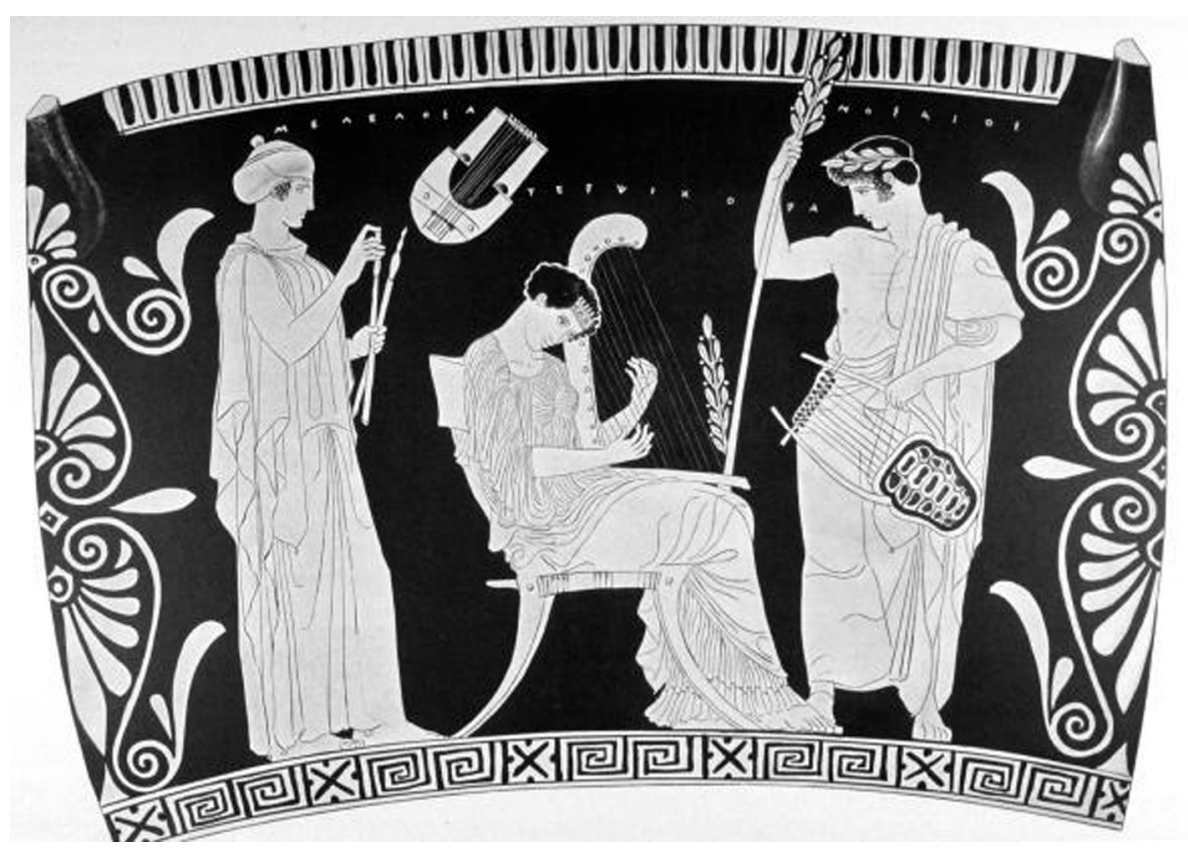

Fig. 73: Ânfora de c. 430 a.C., atribuída ao artesão Peleu, com a harpista no centro tocando uma harpa de ângulo. Do seu lado esquerdo, o auleta experimenta tatilmente a palheta e, do seu lado direito, um músico com uma chélys.

Como já foi apontado, esse modelo tem antecedente em harpas egípcias e mesopotâmicas e a harpa triangular seria uma inovação dos gregos. O trígonov, ou trígona, a era a harpa fechada numa estrutura em três lados tal como as harpas cicládicas, possibilitando uma estrutura mais firme com uma tensão maior das cordas. Esse modelo de ângulo talvez fosse a pektís (n் ппктís), termo que remete à ideia de objetos feitos por assemblage (cf. Bailly, 1963, p. 1551). O verbo pégnymi tem o sentido de fixar junto, prender e deve se referir a uma inovação que dispensaria a moldura frontal.

Platão confirma as diferentes denominações dadas aos instrumentos policordes, embora para o filósofo não devemos nutrir o desejo dos demiurgos de fazê-los: "Então não encorajemos os artesãos de trígonas, pektís e outros instrumentos policordes e de muitas harmonias" (399c-d).

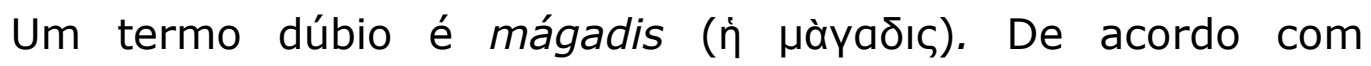
Aristóxeno, ele seria um instrumento igual à péktís (cf. Ateneu, 635e),

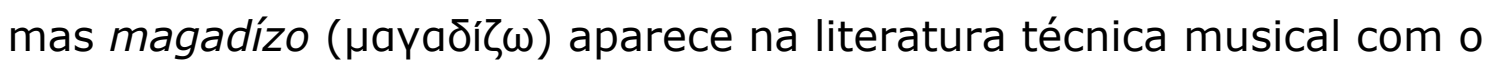


sentido de cantar em oitavas; talvez isso se explique pelo grande número de cordas das harpas, mas isso também é incerto.

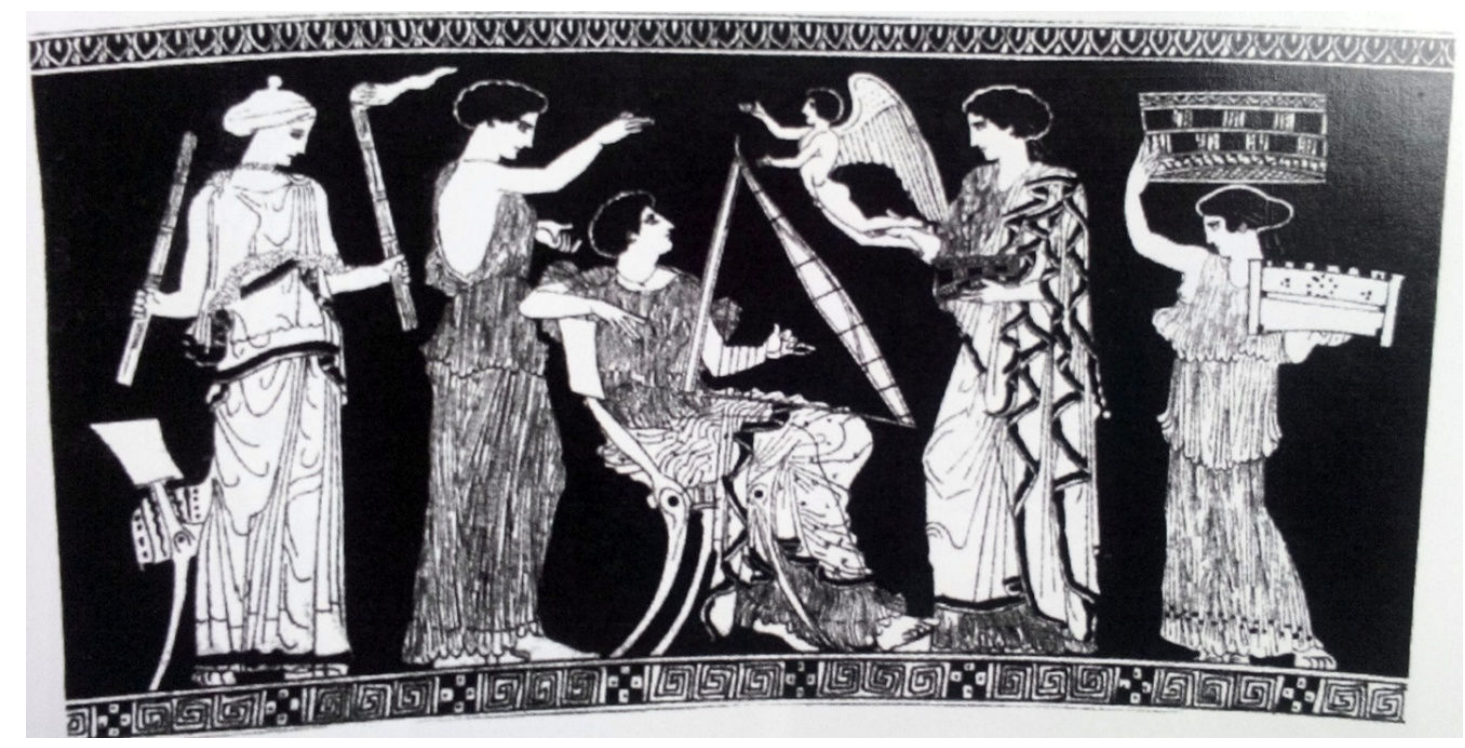

Fig.74: Vaso com musas, uma delas, no centro, tocando a trígonon que, na representação, parece ser um instrumento bem leve, c. 430-20 a.C.

Heródoto, escrevendo no século V a.C., conta que em uma guerra na Ásia Menor, um rei de nome Aliates, esperou o momento certo de atacar os inimigos e estrategicamente avançou ao som de siríngues, pektís e dois tipos de aulós, um mais agudo e outro mais grave (cf. Heródoto, 1985, p. 23). A caixa de ressonância também podia ser construída com as cordas em posição inversa às da figura anterior (fig. 74), ficando a mais longa e grave mais distante do músico.

Mas outro instrumento, de fabricação extremamente simples, apresenta o princípio da graduação como as harpas: a sýrinx. Com seus tubos de junco escalonados, ela será considerada um artefato menor no universo altamente sofisticado de instrumentos como o aulós e a kithára, e é sempre associada à música rural, pastoril, mas seu modelo será decisivo no período helenístico para um novo instrumento que surge adiante: a hydráulis.

Os instrumentos musicais que surgiam nas oficinas podem ter sido desenhados antes de sua construção, mas também sugeridos 
entre uma atividade e outra. Não há uma relação cronológica linear entre artefatos e modelos, nem uma conexão lógica causal entre eles. Seria mais adequado pensar em um padrão de reciprocidade entre eles.

No hino homérico a Hermes, em que vimos os detalhes da construção da chélys-lyra, o deus "inventa" mais adiante a sýrinx, e diz o hino, a partir de outra sophía:

Ele mesmo de outro saber forjou uma técnica.

Fez a sýrinx de som audível ao longe

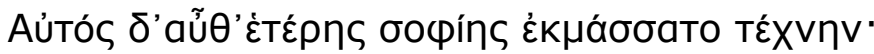

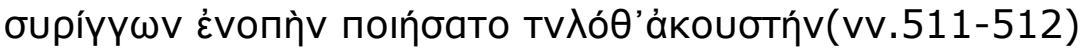

Embora não devamos incorrer no erro de super-interpretar o poema, nesses versos o poeta parece dizer que a sýrinx tem um outro princípio musical, diferente da chélys, que ele fabricara anteriormente, uma outra sophía, como de fato ela tem.

Na figura 75, vemos a imagem ingênua de Pan, carregando uma sýrinx. O escalonamento dos tubos não é visível pois aqui ele ocorre pela outra técnica de produzí-lo: cortando todos os tubos de um mesmo tamanho e depois preenchendo cada um deles com cera derretida até atingir a afinação desejada. Isso era obtido pelo tamanho do tubo que era deixado a vibrar. 


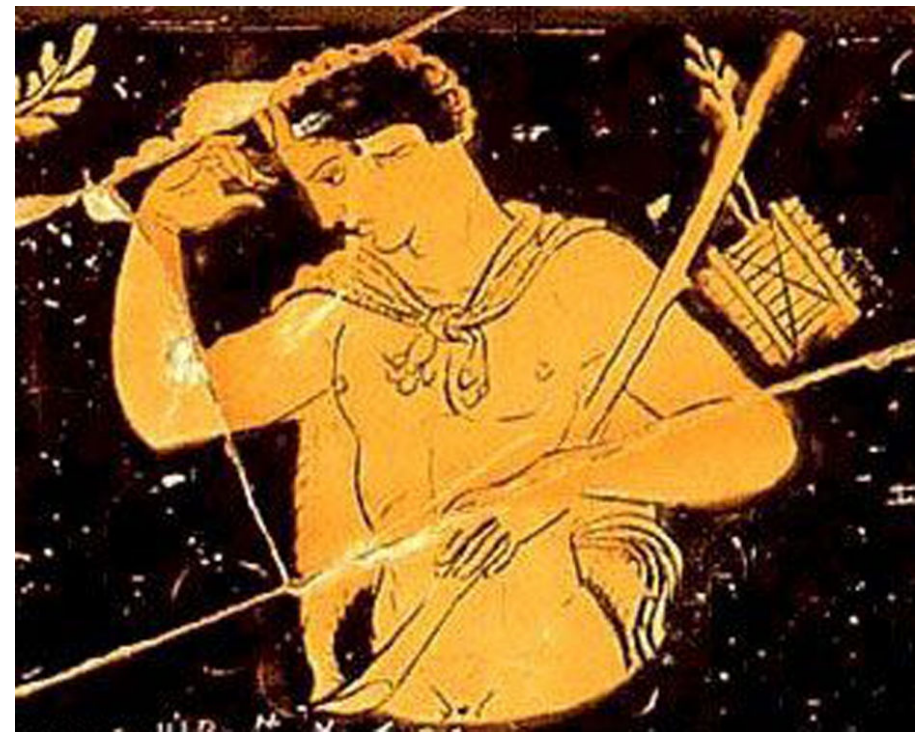

Fig. 75: Detalhe de vaso com Pan e sýrinx, período clássico tardio, c. 405- 385 a.C.

Existem muitas dúvidas a respeito de como o modelo pitagórico esteve presente nas oficinas dos séculos $V$ e IV a.C., assim como tempos poucas referências de como isso aparece na educação musical dos cidadãos e no treinamento dos virtuoses. Sabemos que os jovens aspirantes a virtuoses não aprendiam a escrever música, função que era deixada aos escribas, melographói, quando havia a parte vocal e kroumatopoiós, quando era uma composição puramente instrumental (cf. Bélis, 1999, p. 164). Na prática do dia a dia, os estudantes utilizavam um sistema simples atribuindo a cada nota uma sílaba. Bélis avalia que a teoria musical não era importante na educação musical de um modo geral, inclusive para os virtuoses que, segundo ela, não passavam pelas disciplinas teóricas, nem pelo aprendizado de escrita musical, pois os professores iam "direto àquilo que pudesse garantir as vitórias nos concursos" (1999, p. 35).

Mas a autora refere-se ao fragmento de Phenias, o peripatético, a respeito do citarista Stratonicus da metade do século IV que diz que "Stratonicus foi o primeiro instrumentista a ensinar as coisas da harmônica a seus alunos e de haver apresentado um diagrama" (apud Bélis, 1999, p. 35. n. 48). 
Existem diferenças entre um diagrama em que poderiam estar distribuídas as notas no systema das escalas e um modelo para o estudo da acústica matemática. Mas provavelmente é à segunda possibilidade que Sócrates se refere quando diz que os músicos deveriam ter um conhecimento distinto do restante dos cidadãos, pois estes conhecem "o estudo básico da harmonia, mas não a harmônica" (ád $\lambda \lambda^{\prime}$ oủ Tò òpHovıká) (Fedro, 268e).

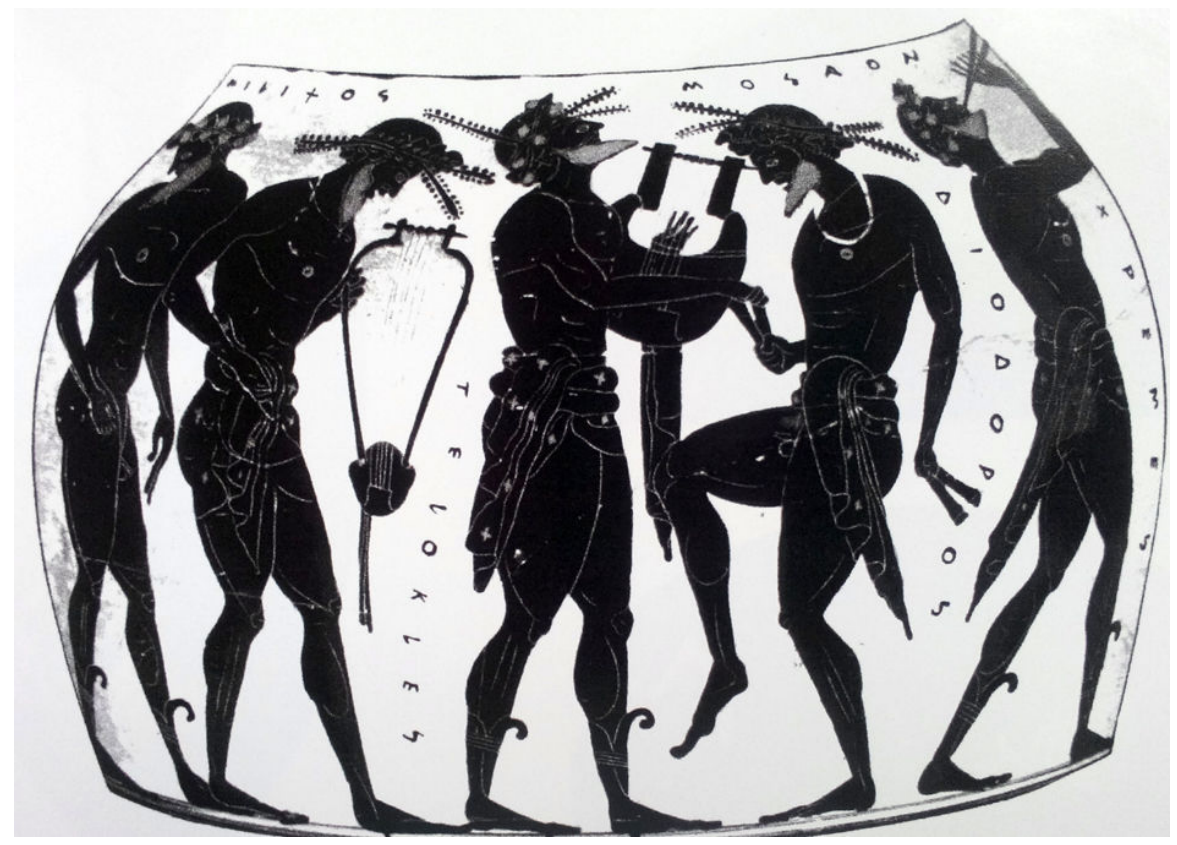

Fig.76: Ânfora ática mostra músicos com cabeças adornadas de coroas: Telokles toca o bárbitos, Musaon, com a cabeça para cima, canta e toca phórminx, Diodorus toca krótala e Khremes toca o aulós, c. 515-500 a.C. 


\section{PARTE II: DA TÉCHNE À EPISTÉME}

Os antigos não tinham nenhuma ideia acerca do que a ciência iria se tornar e nem mesmo tinham uma categoria que correspondesse a ela. O que então eles pensavam que faziam e por quê?

Geoffrey Lloyd, The way and the word

\section{Capítulo 4 - A TEORIA MUSICAL GREGA}

\subsection{Modelos musicais}

Nos fragmentos de uma espécie de apoio para a atividade de preparação da lã, que era encaixado na coxa da tecelã, epinétron, está representada uma cena de batalha em que uma amazona toca uma sálpinx (Fig. 77).

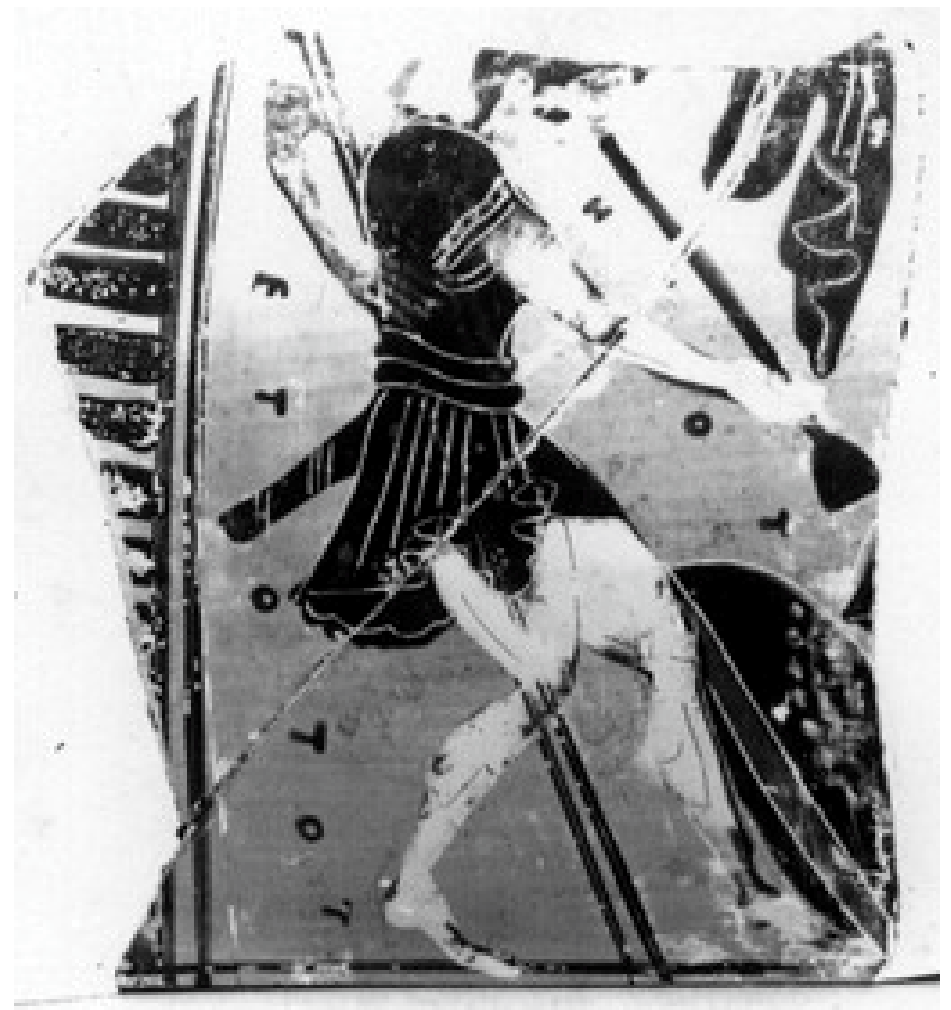

Fig. 77: Sálpinx em fragmento de epinétron ateniense, na técnica de figuras negras, encontrado em Elêusis, na Ática, século VI a.C. 
A sálpinx, como vimos, era utilizada em contextos militares e assim não era incomum aparecer em representações com as guerreiras amazonas. Mas o que chama atenção em três desses fragmentos é a presença de sílabas escritas ao redor da trompetista: to, to, te, to, tee. Em 1983, Bélis interpretou-as como a escrita musical de uma fanfarra, um ta-ta-ra-ta-taa, e buscou verificar a quais intervalos musicais as sílabas corresponderiam.

Não seria possível pensar que a fanfarra tocada pela amazona comportasse grandes intervalos; por outro lado, como indicam alguns textos, a sálpinx soava em uma região grave, indicação que confirma a posição mesma da amazona no epinetron: com o peito curvado para frente, ela não lança notas agudas. As possibilidades da sálpinx grega são fáceis de reconstituir: esse tipo de instrumento, desprovido de qualquer mecanismo, como pistons ou varas, só pode produzir harmônicos naturais, obtidos pela divisão da coluna de ar. A escala musical assim constituída pode ser produzida hoje em dia por um trompete tocando sem fazer uso dos pistons (Bélis, 1984, p.106).

Bélis conclui que na cena retratada a amazona toca um exorméticon, um chamado de partida ou de ataque, e os intervalos deviam ser os de uníssono, quarta e terça maior, que são os harmônicos naturais que um trompete sem pistons ou uma sálpinx executariam facilmente.

A similaridade do trompete sem pistons com a sálpinx se dá pela forma cilíndrica de seu tubo. Contudo o que faz com que a coluna de ar de ambos produza harmônicos naturais é o alargamento de sua base, ou seja, o formato das campanas. Campbell comenta essa morfologia do trompete, que faz com que a coluna de ar produza os harmônicos.

As notas naturais de um trompete ou trombone são muito próximas de uma série harmônica completa. De fato, todo o repertório de fanfarras 
para trompetes naturais está construído sobre o uso de notas da série harmônica. A associação entre trompetes e harmônicos é tão grande que 0 instrumento renascentista de cordas que utiliza apenas harmônicos foi chamado de tromba marina ou trompete marinho. Mas pode ser surpreendente dar-se conta que, se todo o comprimento do trompete fosse um tubo cilíndrico, uma série harmônica completa não seria possível de ser obtida (...); por um design cuidadoso da campânula os modos das frequências são moldados para ficarem bem próximos de uma série harmônica completa. (2004, p. 188)

Portanto, a produção dos harmônicos naturais no trompete ocorre pela morfologia de sua campana e pela aplicação de diferentes graus de tensão dos lábios do músico sobre o bocal, que faz com que o músico selecione o harmônico desejado para soar. Podemos transferir esses comentários, sem muitos danos, à sálpinx antiga, que, apesar de não ter tido o mesmo acabamento do trompete atual, possuía o mesmo formato.

Esse tipo de associação entre morfologia do instrumento e comportamento do som não deve ter passado desapercebido para os construtores de instrumentos e certamente suscitou indagações nas luterias antigas. As comparações eram produtivas. Por exemplo, a observação de que os harmônicos naturais emitidos por um tubo cilíndrico podem também ser produzidos em instrumentos de cordas, faz surgir uma questão do tipo: por que o tubo da sálpinx, quando se coloca a campana, gera um padrão de notas semelhante à divisão de uma corda em partes determinadas, como a metade e a terça parte?

Em Problemas XIX, o Pseudo-Aristóteles explicita algumas das questões que devem ter frequentado as luterias como

Por que a corda grave encerra o som da aguda? Será porque a corda grave é maior? Ela, com efeito, compara-se a um ângulo obtuso, mas a aguda a um ângulo agudo (2001, p. 35) 
Observa-se que nesse momento a analogia geométrica já era um procedimento técnico indispensável, pois a visualização proporciona uma apreensão rápida e abrangente.

Os artífices necessitavam aprimorar os instrumentos com a demanda crescente, ainda mais em uma cultura na qual o poder público determinava que a educação dos jovens passasse pelo aprendizado de música instrumental. Aos poucos devem ter sido criados modelos básicos de instrumentos que pudessem ser fabricados mais rapidamente, e a técnica de construção da chélys adequava-se a essa necessidade. Segundo Ceulemans, a luteria por assemblage

exige meios técnicos diversificados (...) e um grande conhecimento prático. A vantagem é que ela leva a poucas perdas de matériaprima, possibilita um trabalho em série mais rápido e facilita o desenvolvimento de instrumentos de grande porte. Além disso, ela propicia uma redução das paredes das caixas de ressonância, o que favorece a claridade do timbre (2011, p. 78).

A luteria de assemblage nas oficinas antigas gregas aprimorou e agilizou o serviço, acentuando a presença de croquis até chegar a uma abordagem geométrica da estrutura do instrumento.

As oficinas eram lugares de constante experimentação e levaram a resultados curiosos como o trípous, descrito por Ateneu como tendo sido construído pelo músico e teórico de meados do século V a.C., Pitágoras de Jacinto:

Seus apoios ficavam em uma base que podia ser girada facilmente (...) e Pitágoras esticou cordas sobre três espaços separados entre cada apoio. No alto de cada um, ele encaixou um braço e prendeu cravelhas embaixo deles e fez em cima uma decoração juntando as caixas de ressonância. Isso dava uma aparência elegante e uma sonoridade cheia. Ele vinculou as três harmonias: dórica, frígia e lídia a cada um dos grupos de cordas e sentava em um banco (...) e assim ele tocava 
e abafava as cordas com uma mão enquanto se preparava para usar o plectro na outra: com seu pé ele girava a base, para alcançar a harmonia que queria tocar (...). O movimento rápido da base, impulsionado por seu pé, colocava o sistema fluentemente sob suas mãos, e ele praticou esse controle manual em um grau tão impressionante de destreza, que se alguém não visse o que estava acontecendo, julgando apenas pelo ouvido, pensaria que três cítaras estavam tocando juntas, cada uma em uma afinação. O instrumento foi muito admirado, mas após a morte de Pitágoras rapidamente caiu em desuso (1989, p. 299).

No século VI a.C. havia surgido o modelo que aproximara a música da linguagem matemática: as razões musicais pitagóricas. Ao mesmo tempo em que se dedicavam à matemática, os pitagóricos empreenderam investigações acústicas e são comumente considerados os fundadores dessa ciência, com o estudo da música e das cordas vibrantes. Um conhecido termo da matemática pitagórica, hipotenusa, tem o sentido literal de esticar algo debaixo, hypo (baixo), tenein, esticar, tensionar, o que pode indicar uma ligação direta dos pitagóricos com os artífices de instrumentos.

A teoria musical pitagórica tem como ponto de partida a particularidade do sistema musical grego, mas sua intenção é chegar a um modelo universal para a explicação do comportamento do som e do tom musical. Essa sophía musical pitagórica, que ficou conhecida como harmônica ou canônica, está baseada na descrição dos intervalos básicos do sistema musical grego em termos de razões aritméticas.

A contribuição mais duradoura dos pitagóricos será 0 estabelecimento da proporcionalidade inversa entre altura (tom) e comprimento da corda vibrante, inicialmente observada nos intervalos de oitava (2:1), quinta (3:2) e quarta (4:3). Não se sabe se as observações dos primeiros pitagóricos foram realizadas em um instrumento construído com esse objetivo, que seria o monocórdio, ou se isso foi feito com qualquer instrumento de cordas. Contudo, era 
ainda muito distante a ideia de frequência. No século $V$ a.C., um pitagórico como Arquitas confunde conceitos como intensidade e altura (tom).

Max Weber afirma que "a racionalização dos sons parte historicamente e, de modo regular, dos instrumentos" (1995, p.127). De fato, os instrumentos musicais conduziram as investigações acústicas desde a Antiguidade até a era moderna, fazendo o papel tanto de dispositivos de observação do fenômeno musical quanto de modelos de representação de sua matéria-prima. Algumas observações de Olesko a respeito de formas de mensuração precisas do campo visual, que, entre os séculos XVII e XX estariam ligadas a "formas estetizadas de percepção visual" (2007, p. 37), são oportunas para o período que estudamos aqui, se tranpostas para o plano da auralidade, em especial quando ele é abordado na perspectiva pitagórica, em que há visualização dos tons tal como em uma régua.

A história da medição de precisão é mais frequentemente inserida na narrativa da racionalização weberiana. No entanto, a conexão histórica entre a mensuração precisa e as práticas estéticas sublinhadas aqui sugerem que precisão não é meramente acerca de racionalização e objetividade, mas também - e talvez de maneira mais importante acerca de novos modos de subjetividade, especialmente formas de percepção visual que viu a técnica em termos estéticos. O desenvolvimento acerca de objetividade e subjetividade na medição de precisão sugere que a sua história depende tanto da história subjetiva dos sentidos quanto da racionalização (Olesko, 2007, p. 45).

No período arcaico, o empuxe de objetividade das primeiras teorias cosmológicas convive com práticas mágicas e com a novidade da poesia lírica, expressão íntima da subjetividade humana.

Lloyd observa que a noção de sophía entre os antigos gregos era muito mais abrangente do que estamos acostumados a pensar. De início, o termo "sofista" significava apenas que uma pessoa era 
especialista em determinado assunto. Era possível ser sophos em luta, cavalaria, medicina, em todas as áreas do conhecimento e da vida prática (cf. Lloyd, 1987, p. 85). Ateneu fala dessa designação para o termo.

Em geral, a sabedoria antiga dos gregos parece ter sido especialmente voltada para a música. E é por isso que eles julgam a Apolo entre os deuses e Orfeu entre os semi-deuses os mais sábios e os musicais e eles chamavam todos os que praticavam essa arte de sofistas (1989, p. 292).

Segundo Lloyd, os grandes sóphoi eram consultados em questões agudas da sociedade como crises, desastres, pragas ou contaminações e podemos encontrar nessas situações os primeiros impulsos para o desenvolvimento de uma filosofia natural, além do acentuado espírito competitivo grego.

A existência de competições mais ou menos formalizadas em "sabedoria" (sóphos) de um ou outro tipo desde o século VIII a.C., fornece uma pista no que diz respeito a uma abertura eventual para a investigação concernente à natureza (Lloyd, 1987, p. 85).

Desde cerca de 700 a.C., havia debates sofísticos sobre qualquer questão que porventura interessasse ou preocupasse a população. As pressões do público determinavam a inteligibilidade do discurso, como era o caso dos médicos, constantemente solicitados para a resolução de problemas de saúde. Esses debates públicos estavam presentes nos jogos pan-helênicos, dos festivais e das competições dedicados aos deuses, que reuniam não apenas competições esportivas e musicais, mas palestras sobre vários assuntos, por exemplo, "tópicos como teoria dos elementos e os constituintes fundamentais do corpo humano" (Lloyd, 1987, p. 91). 
Os debates possuíam regras pré-estabelecidas, mas elas eram bastante abertas e não dependiam da autoridade dos deuses e nem de ninguém. $O$ fato de eles serem públicos contribuía para a vitalidade das ideias; as questões eram avaliadas, e tinham de ser compreendidas, por todos os ouvintes.

Esses leigos teriam que possuir alguma experiência em avaliar argumentos em outros contextos, como em assembleias ou cortes de direito. Na Índia, as disputas reportadas nos Upanishads são essencialmente esotéricas. Era de responsabilidade dos sábios conferir a vitória ou a derrota. (...). No contexto grego, os oradores dirigem-se frequentemente, e devem ser inteligíveis, a um público muito maior (Lloyd, 1987, p. 87-88).

De acordo com Barros, existem relatos da apresentação nas Olimpíadas de personagens como Heródoto, Hípias e Górgias (1996, p. 11). A característica de antagonizar é encontrada em várias técnicas discursivas gregas e reflete uma vertente do agon grego: as disputas verbais na ágora - que tanto desgostavam Hesíodo.

Oradores e filósofos começam a aparecer nos debates por volta do século VI a.C. Nesse novo discurso, há uma obsessão em suplantar os poetas, como vemos em Heráclito de Éfeso: "Homero merecia ser expulso dos certames e açoitado e Arquíloco igualmente" (1973, p. 89). Com o ambiente competitivo, os estilos de debates tornam-se motivo de disputa, e rivalidades surgem acerca de qual tipo de exposição, apresentação ou representação teria maior excelência ou valor. Uma oratória espontânea começa a dar lugar a uma técnica mais aguda. São oradores que falavam "tanto como poetas, quanto homens de Estado em geral, ou envolvidos na investigação da natureza" (Lloyd, 1987, p. 86). O discurso filosófico passa a disputar o espaço diretamente com os poetas. 
Havelock chama a atenção para essa "nova arte do canto" em que "o fluxo do metro épico é interrompido", na qual polaridades e antagonismos conduzem a um novo ritmo retórico. Havelock comenta a respeito dessa nova arte:

Esta é uma espécie diferente de ritmo, mas é ritmo. A memória é estimulada a construir uma cadeia associativa de causa e efeito e fazer a mente saltar de uma posição para a oposta. (...) Auxiliares acústicos da memorização recebem o apoio suplementar de um tipo de mnemônica que se funda no sentido e não no som, isto é, opera por meio de imagens, que são antitéticas em seus efeitos emocionais. (Havelock, 1982, p. 253).

Uma constelação de pensadores gregos havia se perguntado sobre o princípio que subjaz a todas as coisas. Mas para a verificação das respostas foi preciso questionar as formas de apreensão do mundo. Da maneira que diz Lloyd:

No período pré-platônico filósofos e cientistas debateram os méritos de razão e sensação como fontes do conhecimento e começaram a considerar a questão da relação entre uma teoria e fundamentos ou evidências que a pudesse confirmar (1971, p. 1-2).

A noção de existência de uma estrutura subjacente ao mundo das aparências estava presente nas vertentes mágicas de todas as culturas; contudo, na Grécia surgiu a ideia de que era possível tornála inteligível e um dos caminhos mais bem-sucedidos foi o das razões numéricas musicais. O sistema da música grega estava baseado no modelo do tetracorde, que tinha quatro notas fixas formadas pelos intervalos de quarta, quinta e oitava, selecionadas auditivamente como sendo as consonantes. Para os pitagóricos a música podia tornar o universo cognoscível, por meio da teoria das proporções aritméticas. As consonâncias eram agradáveis porque respondiam à linguagem 
matemática que, por sua vez, mostrava a coesão do universo pelo ajuste harmônico. O termo grego harmós (ò àpuós) vinha das oficinas de carpintaria e refere-se ao encaixe entre duas peças de madeira. Para os pitagóricos, os números eram as peças de madeira e as razões seus encaixes, elas entrelaçavam os tons nos tetracordes tal como os números estariam dispostos no cosmo. Os instrumentos de cordas confirmavam as razões numéricas musicais, bastava comparar consonâncias e dissonâncias, tal como haviam feito durante séculos os músicos e luthiers.

O primeiro conhecimento que temos da teoria musical tal como praticada nos círculos pitagóricos está nos fragmentos de Filolau de Agrigento, do sul da Itália, local que segundo a tradição teria vivido o próprio Pitágoras. Filolau foi contemporâneo de Sócrates e Demócrito em uma época que a música grega e a educação musical já eram bastante desenvolvidas, inclusive com uma notação musical.

Para Filolau, tudo que é possível de ser conhecido tem um número, mas não apenas no sentido do que é comensurável e mensurável, e sim como algo que tem uma forma definida. Os fragmentos de seus escritos parecem reproduzir algo muito próximo de uma apresentação da teoria pitagórica em um debate público. A análise dos textos mostra uma linguagem comum, apoiada nos instrumentos de cordas, de modo que seu discurso facilmente alcançaria os cidadãos. O autor não emprega termos dos teóricos da música como diatessáron, para se referir ao intervalo de quarta, ou diapénte para o de quinta. A oitava também não é chamada de diapasón, mas simplesmente de harmonía. Filolau emprega os termos da linguagem corrente, syllabé e di'okséion, para falar respectivamente dos intervalos musicais de quarta e quinta. Syllabé é substantivo do verbo syllambáno, que quer dizer pegar junto, reunir e, nos círculos musicais, referia-se às cordas abaixo dos dedos do músico em uma posição inicial num instrumento, abrangendo um intervalo de quarta; di'okséion significava através das cordas mais agudas e seriam as 
cordas restantes, mais agudas, tangidas a partir da quarta, ou seja, o intervalo de quinta (cf. Gusmão, 2010, p. 40-2). Toda a linguagem é bastante concreta, suficiente para o entendimento dos cidadãos

No texto de Filolau encontramos a seguinte explicação: "A harmonia abrange uma quarta e uma quinta; a quinta é maior que a quarta por um tom inteiro" (DK 44: B6). Por que dizer algo assim se é perfeitamente possível saber isso de maneira "empírica"? Qualquer músico ou cidadão letrado daquele tempo que manuseasse uma lira de oito cordas saberia que a oitava é a reunião da quarta e da quinta e que a quinta é maior que a quarta por um tom. O autor parece estar preparando a audiência para a verdadeira novidade: as razões numéricas musicais, que confirmavam que a harmonia era 0 fundamento de toda a natureza. A partir daí, bastava a Filolau fazer a demonstração em um instrumento de cordas.

Os números eram vistos como estruturas espaciais. Por exemplo, colocando quatro pontos no plano é possível formar o primeiro sólido, a tetraktýs (ทं тєтрактúৎ), considerada pelos pitagóricos como a chave do princípio organizador do cosmo. Wymeersch explica que, para os pitagóricos, os números

não são simples utensílios de numeração, mas são, eles mesmos, estruturas. Assim, eles distinguem os números ponto, os números lineares, os números planos e os números sólidos, complexificação crescente que determina uma progressão no seu estudo (1999, p. 21).

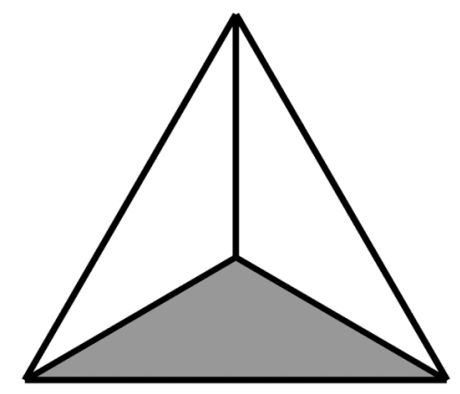

Fig.78: A tetraktýs formava o primeiro sólido geométrico, sendo assim símbolo da natureza para os pitagóricos. 
A geometria pitagórica afastava o caráter antropomorfo da esfera religiosa. A tetraktýs tomava o lugar dos deuses. Na natureza, as coisas estariam dispostas em conjuntos de quatro, assim como para realizar as operações na teoria das proporções, que revela a coesão do cosmo, quatro números são suficientes.

Apesar da exposição mais detalhada da noção de médias proporcionais ter sido feita por Arquitas, que viveu na passagem do século V para o IV a.C., a teoria das proporções, segundo Heath, foi desenvolvida "muito cedo na sua escola com referência à teoria da música e aritmética" (1981, p. 85). Ao dividir uma corda ao meio é possível medir e encontrar o seu ponto e expressá-lo matematicamente como a razão $2: 1$; se aplicarmos a média harmônica, encontramos a quinta (3:2); por meio de quintas ascendentes descendentes sucessivas, construímos toda a escala diatônica, passando por todos os tons. Se aplicarmos a média aritmética encontramos a quarta (4:3). Como diz Wymeersch: "A analogia permite então encontrar entre termos que parecem diversos um princípio de unidade, de coesão, e este princípio é matemático" (1999, p. 23). A tetraktys tornava visível aquilo que era audível nas consonâncias com as quais eram construídos os tetracordes.

Filolau ensina à sua audiência a montar toda a escala musical, baseando-se neste modelo matemático, entrelaçando os intervalos (diasthémata) de quintas tal como a série harmônica. E após a escala musical (sýstema), ele mostra que o mesmo sistema simétrico está presente nos astros, empregando o mesmo termo diásthema, intervalo, para falar das distâncias entre os planetas: "O kósmos é um e começou a vir a ser a partir do centro, e do centro para cima, nos mesmos intervalos (diasthémata) que os de baixo" (DK 44: B17]). Mais que uma terminologia técnica comum, a partir do pitagorismo, música e astronomia estabelecem analogias, e por isso Arquitas vai chamá-las de ciências irmãs, ao lado da aritmética e a geometria. Esse conjunto 
de conhecimentos, mais tarde, quadrivium, será o programa de ensino superior até o advento do Iluminismo.

Lloyd chamou a atenção para os campos da antiga ciência grega em que os termos técnicos cunhados ofereciam definições bastante claras, por exemplo, na anatomia, na zoologia, na astronomia e na harmônica (1987, p. 206). Astronomia e harmônica possuíam também um aparato mínimo de instrumentos criados para propiciar cálculos e medições. Se é possível aferir o grau de avanço técnico de uma ciência a partir de seu aparato linguístico, a harmônica grega constitui-se um campo de extrema sofisticação e a sua terminologia tem dupla origem: nos instrumentos musicais e na filosofia da natureza.

Se Filolau esteve de fato em um debate público para expor o que pensava sobre a natureza, seus argumentos foram bem convincentes principalmente por serem observáveis em diversos instrumentos musicais. Para que isso acontecesse, houve um prolongado desenvolvimento técnico da música, se considerarmos os gestos técnicos como anteriores ao estabelecimento dos modelos. Na música, a partir de repetidas verificações "empíricas" foram construídas escalas qualitativas e meios de representação, mas a tradução das consonâncias em números foi um fenômeno que atravessou os séculos, tornando-se uma forma de compreender o mundo, o fundamento do modelo de harmonia universal. No céu geométrico, aritmético e musical de Filolau, não há lugar para deuses, monstros e titãs.

Nas culturas antigas, cada técnica ou utensílio criado pelo longo desenvolvimento das habilidades humanas tinha sua origem relacionada a um mito. Isso acontecia com ferramentas materiais, como o arco e a lira, ou intelectuais, como a escrita e a linguagem. $O$ pitagorismo, ao relacionar o som de uma corda pinçada a uma representação matemática, inaugurou as condições para um afastamento da matriz mítica dos instrumentos musicais, mesmo mantendo seus princípios associados a uma metafísica. 
Certamente houve uma penetração da proposta pitagórica nas luterias. Mas não sabemos nada a respeito de como os aulotrépoi mediam os intervalos entre os orifícios, tampouco temos informações a respeito das mensurações de cordas entre lyropoiói. Teriam eles aplicado os princípios matemáticos e desenvolvido modelos para suas miniaturas? Em caso positivo, eles teriam de adaptar e transformar a a morfologia e outros aspectos do instrumento.

A noção de uma ontologia do número foi alvo de críticas de Aristóteles (987b-28), mas na obra peripatética Problemas XIX, o autor, que não se sabe se é o próprio Aristóteles, questiona por que um intervalo entre duas notas é de oitava. A explicação dada está no contexto da teoria pitagórica: quando uma corda é tangida na metade de seu comprimento e depois no seu comprimento total, o intervalo entre elas forma a consonância de oitava. Em seguida, o autor amplia essa justificativa para o tubo do aulós, numa espécie de aula de organopóia musical: "também nos aulói, a oitava é formada pela distância dupla, e assim fazem os aulotrýpai. A quinta, do mesmo modo, é formada pela distância hemíola" (919b, 1-8). ${ }^{29}$

O texto provavelmente refere-se a um orifício de registro para oitavar, expediente bastante comum em instrumentos de sopro. Contudo, esse tipo de registro não costuma ser feito no meio dos tubos e sim acima e atrás, como numa flauta-doce. Mas, mesmo que o orifício fosse aberto na metade do tubo, não é só a localização do orifício que determina o seu papel. Como diz Campbell et al: "O tom obtido pela abertura de um orifício particular não depende apenas da posição do orifício, mas também de seu diâmetro" (2009, p. 79). Além disso, outros elementos como o formato do tubo e a forma de emissão sonora contribuem igualmente para tal. Supondo que o autor estivesse falando do recurso de overblowing ${ }^{30}$, um instrumento cônico oitavaria,

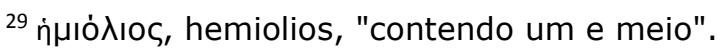

$30 \mathrm{O}$ overblowing é um recurso muito comum e consiste em imprimir uma pressão maior na coluna de ar utilizando movimento do diafragma e/ou dos lábios.
} 
produziria um intervalo duplo, mas um instrumento cilíndrico como o aulós e com a emissão passando por uma palheta dupla, geraria uma $12^{\mathrm{a}}$ (oitava + quinta) (cf. Campbell et al. p. 78).

Sendo assim, essa segunda parte do problema 23 não é condizente com a prática real dos aulotrýpai e é na verdade uma tentativa de apresentar uma correspondência prática para as razões musicais pitagóricas. Isso não significa que não tenha havido uma penetração dos recursos de mensurações das distâncias com base nessas proporções nas luterias, talvez isso não fosse nem mesmo uma grande novidade para os luthiers, mas ela não poderia ser o único recurso, simplesmente porque não funcionaria e os organopoiói tinham encomendas que não podiam atrasar.

O pitagorismo que, no seu início, poderia estar mais para uma corporação de artesãos estendeu sua influência a vários campos diferentes do conhecimento como a arquitetura e a anatomia. As investigações pitagóricas tinham dois eixos: a essência do número (lógos) e as relações entre eles (análogos). Este último aspecto era confirmado pela música. Mas a ideia de uma essência do número abriu e fechou portas ao longo de ao menos um milênio de domínio desse modelo de ciência no Ocidente. Mas devemos tomar cuidado ao pensar numa ciência pitagórica, haja vista que os antigos não tinham categorias que correspondessem exatamente ao que entendemos como ciência, e muito menos arte.

Platão, no Timeu, esboçou algumas teorias bastante curiosas a respeito da audição afirmando que o som penetra no cérebro e no sangue até a base do fígado (cf. 67b). Na mesma obra, o modelo de cosmos musical de Filolau é retomado por Platão na passagem em que ele descreve a escala musical como um princípio amalgamador do cosmos (cf. 35b-36c). Essa concepção, que ficou conhecida como harmonia das esferas, aparece na narrativa fantástica do soldado armênio Er, no final da República (cf. 614b-617d), e pode ter lançado as sementes da polifonia na imaginação. Nessa metáfora, cada planeta 
é representado por uma sereia que emite um tom da escala musical, polifonicamente, trazendo a música, arte do tempo, para a simultaneidade do espaço. Essa imagem terá uma força duradoura e, no século II d.C., Claudio Ptolomeu, em sua obra Harmônica, fará conexões entre aspectos planetários e intervalos musicais. No entanto, as relações entre modos musicais e planetas só vão aparecer de maneira explícita, mais tarde, nos escritos islâmicos medievais, como do filósofo Al-Kindi (801-873).

Hallyn em seu livro La structure poétique du monde, investigando as descobertas de Copérnico e Kepler, ocupa-se do momento da constituição das suas hipóteses.

Este "momento", que Peirce chamou de abdução e que engloba "todas as operações pelas quais as teorias e concepções são engendradas, é aquele que coloca o maior problema tanto ao epistemólogo quanto ao historiador da ciência. Certamente, em alguns casos, as conexões factuais fornecem ao menos explicações parciais para a aparição de uma hipótese: observação de novos fenômenos, desenvolvimento de técnicas novas, progresso ou revoluções realizadas dentro de disciplinas correlatas... Mas, de um modo geral, a constituição de uma nova hipótese permanece um momento enigmático (1987, p. 9-10).

Mas se olhamos do ponto de vista da história da técnica musical, a hipótese pitagórica não nos parece tão enigmática assim. Para os antigos, o pitagorismo foi um modelo que trouxe uma explicação perfeitamente observável, em uma corda esticada. A noção de éthos dos modos musicais igualmente ganhou força com a ideia de que os tons musicais encadeados num systema tinham um logos, um discurso. 


\subsection{O éthos musical na obra de Platão e Aristóteles}

No mito grego, o poder da música foi tematizado no canto de Orfeu, que domou as feras, no trabalho de Anfion, que, com sua lira ajustou as pedras do muro da cidade de Tebas. Há relatos lendários acerca da atuação de Pitágoras como taumaturgo musical, mas a primeira referência que temos de uma teorização da ideia de correspondências entre música e disposições anímicas foi feita pelo músico Dámon, conselheiro de Péricles, na metade do século $V$ a.C., em Atenas. Para Barker, essa certeza, entre autores antigos e modernos, de que Dámon tenha sido o responsável pelas correspondências entre éthos e harmoníai não é justificada. Para o autor, há evidências dessas correspondências em Dámon apenas no que diz respeito a ritmos (cf. Barker, 2007, p. 252, n. 29). De qualquer modo, Péricles foi um grande incentivador das artes e, de acordo com Plutarco, responsável pela construção do Odeon, uma arena dedicada especialmente à música, para as Panatenéias. Segundo Bélis, o próprio Péricles participava como juiz das provas (cf. 1999, p. 130).

Pouco restou da obra de Dámon, exceto o discurso Areopagiticus, no qual defende que o Areópago, conselho de membros da aristocracia ateniense, deveria ser o guardião das leis e bons costumes da cidade. Sendo assim a música era fundamental pois, influenciando a alma humana, afetaria a alma do Estado. O teórico é referido por Sócrates na República:

Devemos ser cautelosos acerca de mudar para um novo tipo de música, pois isso arriscaria uma mudança total. Os modos (trópoi) da música nunca são mudados sem que se mude as maiores leis fundamentais (nómoi) do Estado, como disse Dámon, e eu concordo (424c,3-6).

Platão foi um seguidor da doutrina de Dámon, mas ela não era aceita tacitamente por todos os filósofos. Seu contemporâneo Diógenes 
Cínico dizia que "as pessoas poderiam afinar as cordas da lira e ainda assim ter dissonâncias na alma" (apud Schueller, 1988, p. 26).

Em 1905, foi encontrado um papiro em uma tumba egípcia na cidade de Hibeh com fragmentos de textos possivelmente do sofista do século V a.C., Hípias de Elis, com várias considerações à música. Hípias foi figura central de dois diálogos platônicos, provavelmente espúrios. De acordo com Schueller, ele

não aceitava que a música pudesse expressar os atributos de objetos naturais como o louro (consagrado a Apolo) ou a hera (consagrada a Dioniso). Para ele, a lei natural era uma coisa e a lei feita pelos homens, outra. A melodia enarmônica, ele afirmava, não "fará seus partidários mais corajosos que o cromático os faria covardes" (1988, p. 29).

Aparentemente essas noções ligadas ao éthos musical foram preservadas pelos antigos, mais que as objeções a elas. E um dos motivos desse sucesso foi a tarefa empreendida por Platão de demonstrar a validade das teorias de Dámon a partir da harmonia pitagórica. Diversas culturas conceberam a música como força mágica, mas entre os gregos esse poder tinha uma expressão matemática, o que concedia legitimidade, pois os números representavam 0 desvelamento da ordem intrínseca na natureza. Esse foi um elemento crucial da abordagem platônica do éthos musical, que seguiu por duas vias.

Em primeiro lugar, se as relações harmônicas são os elementos fundamentais da estrutura do universo, seus movimentos são similares aos da alma, e sendo assim, a música teria condições de alcançar essa instância íntima da natureza humana. O outro aspecto passava pela concepção platônica de arte, fundamentada na sua teoria das formas, que propunha que o mundo das ideias teria o valor essencial: as ideias sendo reais e imutáveis, sua apreensão só poderia ser feita pela razão, 
não pelos sentidos, pois esses captam apenas o fenômeno, considerado enganoso.

Na República, Platão cria uma metáfora e uma hierarquia para argumentar em favor dessa teoria. No ponto mais alto da escala humana está o filósofo, em seguida o artesão, depois o pintor. O pintor não sabe nada do objeto, uma cerâmica, por exemplo. Ele a pinta criando ilusões de realidade. O artesão faz uma cópia a partir da ideia, a qual é contemplada, diretamente, apenas por aquele que sabe para que ela serve, o filósofo.

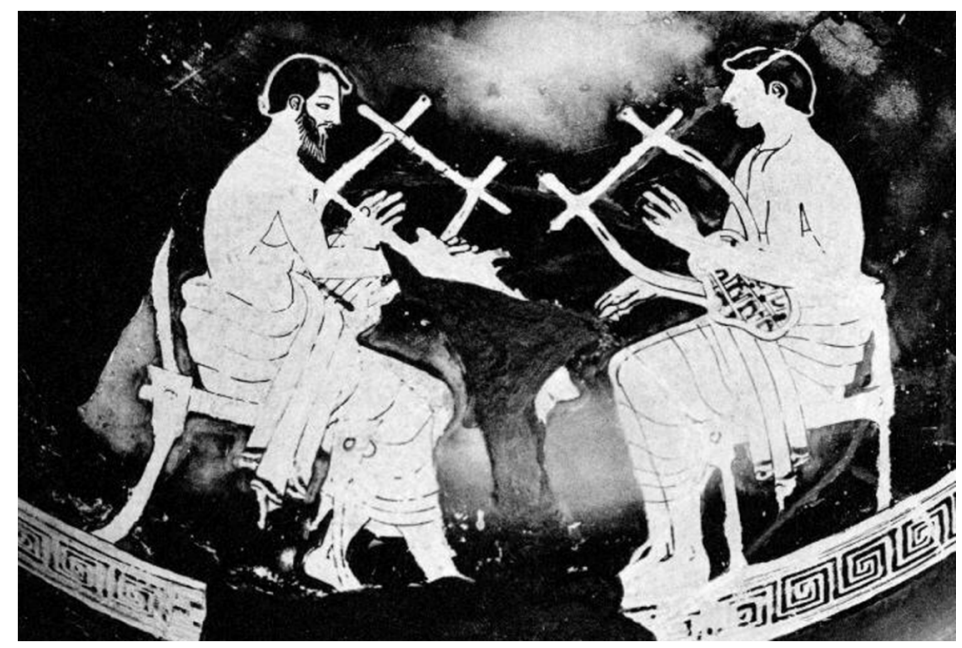

Fig. 79: Hydria ateniense mostrando com uma aula de lyra. O professor, de barba, toca uma lyra maior, que parece ter uma caixa de ressonância de madeira, e o aluno uma chélys, c. 500-450 a.C.

Nas primeiras seções do livro 10 da República, Platão examina o papel dos pintores, dos poetas, dos autores de tragédia e comédia, mas não inclui em seus comentários os músicos. Por conta disso, Dahlhaus e Katz consideram que, para o filósofo, a música seria diferente das outras artes, pois ocuparia uma posição intermediária entre o mundo das ideias e do fenômeno. Segundo os autores, para Platão,

a música é diferente das outras artes em sua posição ética porque tem uma ligação especial com o mundo das Ideias. Desde Pitágoras, a música estava relacionada à metafísica. Assim também para Platão. 
Desse modo, enquanto mantinha que seria necessário para a música estar combinada às palavras que imitam as Ideias - pois os sons sozinhos são meras sensações (Rep. II, 398) - os sons em si mesmos, desacompanhados das palavras, são a representação primordial da Ideia e um objeto elevado de contemplação (Rep. VII, 529-32) (1987, p. 9).

Ao estabelecer que os tons musicais conectam-se ao aspecto metafísico da realidade, que por sua vez é considerada verdadeira, Platão confere a eles um poder primordial. Ele legitima, por meio de uma explicação metafísica, as implicações éticas da música.

Tanto na República (cf. 398-403) quanto em Leis (cf. 700 a-e), cujas obras tratam da música no contexto que podemos chamar de uma "política de Estado", Platão define os estilos melódicos, ou modos, que deveriam ser banidos: o lídio, por expressar tristeza, e o jônio, por levar à indolência. Ele indica os dois modos que deveriam ser mantidos e encorajados: o dórico, que é "uma harmonia que imita as expressões e os acentos de um homem corajoso na batalha" $(399 a, 6-8)^{31}$ e o frígio, escolha que será alvo da crítica de Aristóteles.

Os tons musicais não constituíam a música grega como um todo, que era uma arte da performance e englobava a poesia e a dança. Mas Platão insiste na contraparte metafísica dos tons. A conexão entre a música e a astronomia também fornecia uma provisão considerável de explicações e motivos para a proposta de poder educativo da música. O filósofo afirma que as duas ciências apresentavam movimento harmônico: "tal como os olhos fixam-se na astronomia, assim os ouvidos fixam-se no movimento harmônico; essas duas ciências são irmãs, assim dizem os pitagóricos, e nós concordamos" (530d). Os astros descreveriam o movimento visível e a música, o audível.

31 Claudio Monteverdi (1567-1643) no "Prefácio" dos Madrigais guerreiros e amorosos, de 1638, afirma que se inspirou nessas linhas da República de Platão para criar o stilo concitato. (cf. Treitler,1998, p. 666). 
Portanto os tons, assim como os planetas, influenciariam a natureza anímica humana.

Platão observa atentamente os instrumentos, pois, se os instrumentistas dominavam as poderosas harmonias, eram eles quem possuíam a habilidade e o conhecimento para abalar a estrutura do Estado, algo que o preocupava. O aumento da complexidade da música grega relacionava-se ao avanço das técnicas de construção de instrumentos, assim como à lenta e gradativa aceitação das apresentações puramente melódicas, como sugerem os concursos de música instrumental, como já vimos. Para Platão, a sofisticação dos estilos melódicos deveria ser rejeitada e a simplicidade exaltada como um valor primordial. Na República, Sócrates pergunta a seus interlocutores:

- Então, nem os instrumentos de muitas cordas nem o de muitas harmonias devemos querer em nossas canções e melodias?

- Para mim não, evidentemente.

- Sendo assim, não devemos encorajar os construtores de trígonas, de péktis e todos os instrumentos de muitas cordas e muitas harmonias.

- Claro que não.

- E os construtores de aulós e os auletistas devem ser acolhidos na cidade? Não acontece dos instrumentos de muitas cordas imitarem as panarmonías do aulós?

- Sim, é evidente.

- Então a ti parece que a lira e a cítara são os instrumentos úteis à cidade, enquanto que no campo as pessoas devem utilizar a sýrinx.

- É o que indicam nossas palavras (399 d-e).

Platão desgostava do aulós por conta de suas variações tonais sutis e escalas que se expandiam com as mudanças de modos, a partir do aperfeiçoamento das digitações ou outros procedimentos técnicos como as syríngues deslizantes, dispositivos que permitiam mudanças 
na afinação. De acordo com Platão, as mudanças sucessivas de modos criavam dificuldades de percepção da sua finalidade. Ele critica também que os instrumentistas de cordas tivessem começado a imitar as complexidades dos auletistas. A filosofia platônica apresenta fortes argumentos em favor da razão e chama a atenção para a incerteza da experiência sensorial, algo que já estava presente no pensamento présocrático. Mas, por meio dela, compreendemos melhor o universo sofisticado da música grega da passagem do século $\mathrm{V}$ para o IV a.C.

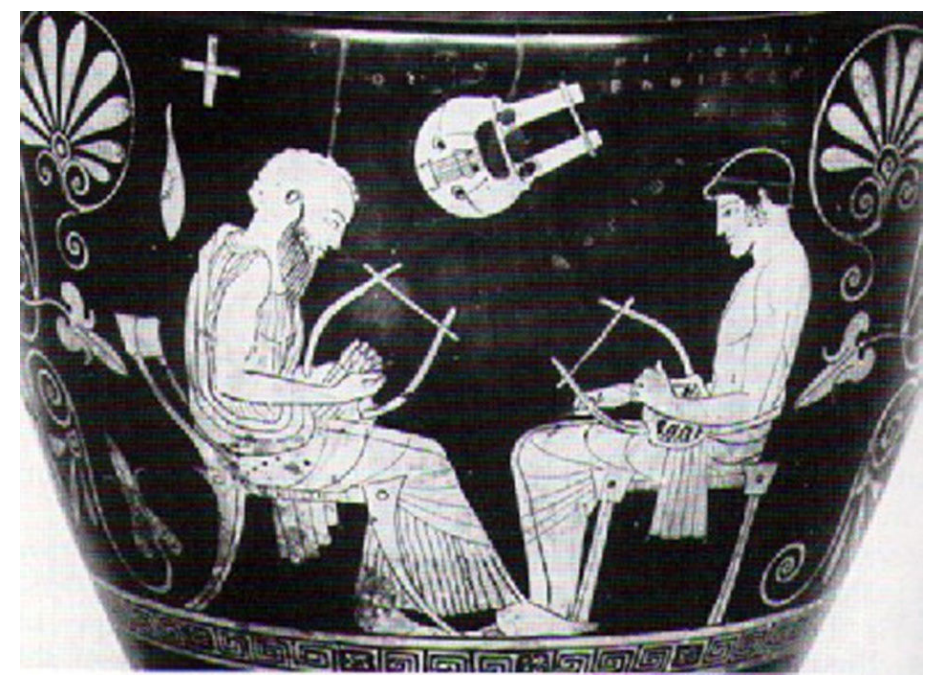

Fig. 80: Skyphos ateniense, do pintor Pistoxenos, retrata Iphikles recebendo instrução de Linos, c. 470-460 a.C. Na parede, um instrumento que tem a base redonda da phórminx, mas com os braços independentes.

Aristóteles, no livro VIII da Política, dialoga diretamente com a filosofia platônica ao discutir se a música deveria ser incluída na educação dos jovens. Ele propõe uma reavaliação da eficácia do poder da música e de sua finalidade. A indagação aristotélica parte de três funções da música que devem ser investigadas: diversão e

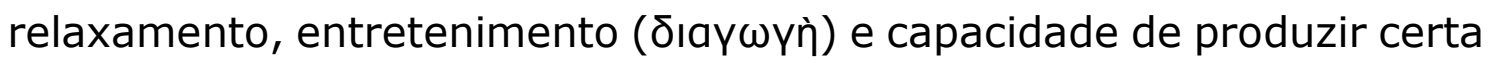
qualidade de caráter "tal como a ginástica é capaz de produzir uma certa qualidade do corpo" (1339 a). Seu método toma as opiniões comuns como termômetro da verdade, portanto, se todos dizem que a música é prazerosa, "seja ela instrumental, ou vocal e instrumental" 
(1339b), ela de fato diverte, relaxa e é um passatempo cultural. Nesse sentido, a música é ótima para dar aos jovens algo para fazer, de modo que eles fiquem quietos, tal como acontece com "o chocalho de Arquitas, uma boa invenção que as pessoas dão às crianças para que fiquem ocupadas e não quebrem os móveis" (1340b). Além disso, é importante que o jovem aprenda a tocar o instrumento e a cantar, pois "é algo impossível, ou difícil, tornar-se um bom juiz de performances se não tiver participado de uma" (1339b). Nesse aspecto, no século II d.C. Ptolomeu seguirá Aristóteles, como veremos adiante; já Boécio, no século VI a.C. apostará em Platão.

Ao investigar se a música alcança e influencia o caráter e a alma humana Aristóteles considera o senso comum: "todos, ao ouvirem imitações [musicais], são lançados num estado de sentimento correspondente, mesmo sem o ritmo e a poesia" (1340a). Mas quais seriam esses efeitos? Ele segue em linhas gerais as direções platônicas quanto ao éthos dos modos, dos ritmos e dos instrumentos, contudo, discorda nas formas de utilização:

Aceitamos a divisão de harmonias propostas pelos filósofos em melodias éticas, práticas e entusiásticas mantendo, contudo, que a música não deva ser estudada para se obter um único benefício apenas, mas vários (1341b).

Aristóteles critica a utilização da música apenas para fins educativos. Para ele, todos os expedientes da música devem ser utilizados, pois as melodias e os instrumentos servem a vários fins, não a um somente. Além de educar, ela tem a função recreativa e catártica (patética).

É evidente que devemos empregar todas as harmonias, embora não da mesma maneira. Devemos utilizar os modos mais éticos para a educação e os práticos e os patéticos para ouvir quando executados por outros, pois qualquer experiência que ocorra em algumas almas 
pode ser comum a todas, embora em diferentes graus de intensidade - por exemplo, melancolia e medo (oion éleos kai phóbos). No caso das paixões entusiásticas, algumas pessoas são afeitas a ela e sob a influência da música ritual, quando se utilizam melodias entusiásticas, nós as vemos serem lançadas a um tal estado, que é como se tivessem tomado um medicamento purgativo; a mesma experiência deve também ser dirigida aos compassivos e aos medrosos a fim de produzir outros estados emocionais em todos os tipos de indivíduos, e todos devem passar pela catarse e sentir a agradável sensação de alívio; da mesma maneira, os modos práticos, que incitam à ação, são um deleite inofensivo às pessoas (1342a).

Para Aristóteles, o modo dórico, e nenhum outro, deveria ser empregado na educação dos jovens por ser o mais ético, e por sua natureza mediana, que ensinaria a moderação. Isso se deve ao fato de o modo dórico ocupar a posição central do sistema grego, que reunia o frígio, o lídio e o mixolídio de um lado e o hipodórico, o hipofrígio e o hipolídio, de outro. Esse caráter espacial do sistema musical grego revela a prática de construção de diagramas explicativos para a demonstração dos sistemas. Para Aristóteles, Sócrates havia errado na República ao recomendar o modo frígio junto com o dórico para a educação dos cidadãos e simultaneamente rejeitar o aulós, pois

o modo frígio, dentre as harmonias, tem o mesmo efeito que o aulós dentre os instrumentos, ambos são orgiásticos e patéticos. Isso fica evidente na poesia no caso do ditirambo que é admitidamente um metro frígio; e os especialistas dão inúmeras provas disto, particularmente o fato de que Filoxenus ao tentar compor um ditirambo, Os Mísios, utilizando o modo dórico, não ter conseguido (1342 b).

A tipologia dos instrumentos variava de acordo com sua tessitura, sua capacidade de ressonância, seu timbre, sua penetração sonora e ainda com sua origem histórica e mítica. As afinações dos 
instrumentos distinguiam os modos musicais e, em alguns casos, a terminologia relacionada a elas designava as suas características. Por exemplo, termos como afinação tensa (esticada) e relaxada (solta) podiam referir-se tanto a um estado de espírito quanto ao ponto de tensão de uma corda em um instrumento.

Aristóteles argumenta em favor de harmonias que haviam sido excluídas por Sócrates, ou Platão, como a lídia, por ser um modo relaxado. Para ele, os idosos são beneficiados ao utilizarem esse tipo de melodias. Em resumo, para ele, não se deve excluir nenhum modo, mas adequá-lo à idade, ao tempo e ao lugar. O jovem deve ser direcionado à educação musical, mas desde que se saiba o que é adequado ou não: "fica claro que nós temos que estabelecer três cânones para guiar a educação: moderação, possibilidade e adequação (tò te méson, tò te dynatòn kaì tò prépon) (1342b 33-35). Aristóteles não confunde, na educação musical dos jovens aristocratas atenienses, o caráter lúdico educativo da música com a ideia de diversão, que segundo ele não é útil ao aprendizado.

Não é difícil de ver que não se deve fazer da diversão objeto de educação dos jovens, pois a diversão não caminha com o aprendizado - que é um processo doloroso (1339a).

No caso dos instrumentos, deve-se observar quais deveriam ser utilizados:

Os aulói não devem ser apresentados na educação, nem outro instrumento profissional (TEXVIkòv òpyavov), como a cítara ou outro desse tipo, mas apenas aqueles instrumentos que tornarão os alunos atentos às aulas e ao próprio treinamento musical. O aulós não é

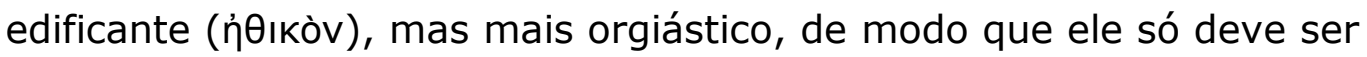
empregado em situações de catarse e não de instrução. E gostaríamos de acrescentar que o aulós tem o inconveniente adicional de evitar o emprego da palavra (1341a, 18-26). 
Percebe-se que a produção da catarse por meio da música estava inserida profundamente na vida grega. É importante sublinhar que ela era produzida não só por uma certa qualidade da harmonia frígia, mas pela ressonância, penetração e volume de som do aulós que provocava uma reação psicofisiológica. O termo catarse (káӨapбıc) era utilizado tanto no contexto médico quanto no dos rituais de purificação. Isso fica evidente no trecho citado anteriormente em que Aristóteles compara a reação à catarse a de um purgante.

A questão da rejeição do aulós passa por essa função nos cultos orgiásticos, mas Havelock considera que um dos motivos da rejeição do auletista adviria da sua gradativa independência do cantor:

Os instrumentos de sopro sempre exigiam que houvesse um artista para recitar e outro para tocar (exceto quando a música se limitava aos interlúdios); (...) Essa situação ajuda a explicar por que, quando a execução musical - em nosso sentido de "musical" - começou a emergir como uma arte autônoma, lá pelos fins do século $V$ a.C., (quando isso era de esperar, pois a leitura de poesia começava a ter incremento), foi como concerto de aulós que ela apareceu. $O$ auletista, sempre um indivíduo posto à parte na recitação, começou a apresentar-se por conta própria (1994, p. 26).

Na concepção platônica, a questão da proeminência da música vocal sobre a instrumental estava em contradição com o fato de os tons musicais presentes nas relações harmônicas manterem a conexão com o mundo das ideias. É sugestivo pensar que, no mundo de Hesíodo, as musas cantavam e dançavam, já no mundo da harmonia das esferas de Platão, as sereias entoam um único tom na ciranda dos planetas, uma visão menos musical e mais filosófica. No Fédon, Sócrates iguala a música à filosofia (cf. 61). O fato de Platão condenar a utilização dos instrumentos não significa que não lhes atribuísse poder, ao contrário (cf. 669c-670a). 
Por seu lado, Aristóteles apoia a utilização da música instrumental desde que na situação apropriada, pois, no caso da educação dos jovens, além do aulós:

outros instrumentos são desaprovados como a péctis, o bárbitos e os instrumentos feitos para dar prazer àqueles que os tocam: a heptágona, a trígona e a sambuca, que requerem destreza manual (1341a-b).

Além do fato de instrumentos como a trígona e sambuca exibirem muitas cordas, o que estimulava o virtuosismo, a sua condição de estrangeiros pode ter pesado na sua rejeição por parte de Platão e Aristóteles.

Outra obra do corpus aristotelicum na qual aparece uma questão sobre o éthos musical é o Livro XIX de Problemas:

Por que os ritmos e as melodias, que são somente sons, assemelhamse a caracteres morais, mas não os sabores, nem as cores e nem os odores? Será porque são movimentos também as ações? E a ação já encerra um caráter moral, mas os sabores e as cores não atuam do mesmo modo? (29).

A noção de movimento é central na filosofia aristotélica e Aristóteles a preserva na música, mas afasta a ideia da sua influência no comportamento de qualquer relação com a astronomia, distanciando-se da visão pitagórica e platônica. Mas é preciso ressaltar que as objeções de Aristóteles ao pitagorismo referiam-se à metafísica e à astronomia, pois no que tange às razões numéricas musicais, ele estava de acordo que elas fossem os princípios da ciência da música, tal como está nos Analíticos posteriores: 
O que é a consonância? É a razão dos números no agudo e no grave. Por que o agudo harmoniza com o grave? Porque uma razão aritmética situa-se entre os dois (90 a).

A refutação do modelo astronômico musical pitagórico representou uma ruptura com Platão. Caberá à Aristóxeno de Tarento questionar as relações entre a música e a aritmética e, para isso, ele utiliza o arcabouço teórico da filosofia da sensação aristotélica.

\subsection{Instrumentos musicais na harmônica aristoxeniana}

A cidade de Tarento, onde nasceu Aristóxeno, abrigava uma comunidade pitagórica importante, a qual, até onde sabemos, era frequentada por seu pai Spintharus e por Arquitas de Tarento, geômetra pitagórico da geração posterior a Filolau e que foi tema de interesse tanto de Aristóteles, quanto de Aristóxeno. ${ }^{32}$

Nos fragmentos de Arquitas há referências à música como sendo uma das quatro mathémata, os instrumentos de conhecimento do mundo: aritmética, geometria, astronomia e música. Arquitas também expõe detalhadamente o cálculo das médias proporcionais como uma forma de encontrar as razões das consonâncias, que já abordamos em outro estudo. ${ }^{33}$ Para Arquitas, todos os intervalos musicais em uma corda deveriam ser encontrados pelo cálculo da média harmônica, com exceção da oitava, que era dupla. Sendo assim, o sistema musical de Arquitas chegava a um impasse ao se daparar com o tom inteiro, pois ele não poderia ser dividido ao meio. O sistema musical grego do século $\checkmark$ a.C. utilizava intervalos próximos do que consideramos hoje meiotom, no gênero cromático. Para Arquitas esse intervalo deveria ser calculado pela média harmônica, o que não correspondia exatamente

\footnotetext{
32 "Aristóteles escreveu mais livros sobre Arquitas do que sobre qualquer outro personagem. Ele dedicou três livros sobre a filosofia de Arquitas e escreveu outro que consistia de um sumário ao Timeu e aos escritos de Arquitas (Huffmann, 2010, p. 4). Aristóxeno escreveu uma biografia de Arquitas.

${ }^{33}$ Gusmão, 2010.
} 
às afinações correntes de seu tempo. As mathémata entrelaçadas deixavam o caminho aberto para uma ontologia do éthos dos modos musicais.

Aristóxeno iniciou seus estudos no ambiente pitagórico em Tarento e por volta de 350 a.C foi para Atenas estudar com Xenófilo, um conhecido pitagórico da cidade, para depois tornar-se aluno de Aristóteles no Liceu. Na obra Elementos de harmônica, da qual restaram partes susbtanciais, ele sublinha uma força de organização imanente da mélos epistéme: "nenhuma das coisas sensíveis possui uma ordem tão grande e de tal qualidade" (A-5, 29-30). Mas a sustentação do seu sistema não é dada pelas mathemata e sim pela própria estrutura do mélos. Aristóxeno argumenta que o conhecimento da correlação entre os tons é mais importante que a sua medida, o que não deixa de ter ligação com o pensamento geométrico proporcional de Arquitas, mas Aristóxeno é taxativo: o primeiro julgamento deve ser feito pelo ouvido.

Uma das noções mais importantes da teoria harmônica aristoxeniana para a coesão musical é a de função (dýnamis), em que cada nota é definida pelo seu contexto ou, poderíamos dizer anacronicamente, pela sua função melódica, no caso, a posição ocupada por uma nota ou por um intervalo em uma escala dada. A medida de um intervalo ou de um conjunto deles pode ser diferente e eles serem iguais do ponto de vista da função. Inversamente, intervalos de mesmo tamanho podem ser ouvidos de modo diferente, pois suas funções diferem. É claro que ainda estamos muito distantes de uma teoria das funções harmônicas e melódicas, que só se desenvolverá plenamente no seio da tonalidade, tal como entendida pela teoria musical a partir do século XIX, mas podemos considerar essas formulações como o seu início.

Os tetracordes são organizados em escalas a partir dos conceitos

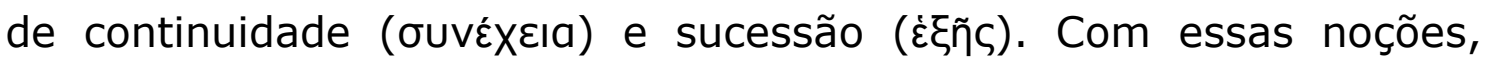
advindas da filosofia aristotélica, os encadeamentos dos tetracordes 
são inseridos numa lei necessária e natural de ordenação melódica. Aristóxeno organiza o sistema musical grego dentro do quadro da filosofia natural aristotélica. ${ }^{34}$ Seu objetivo é mostrar que o mélos tem uma estrutura intrínseca que não necessita de elementos extramusicais para sua ordenação.

Em Elementos de harmônica, Aristóxeno fala pouco a respeito do éthos musical, como foi discutido por Platão e Aristóteles. A sua ciência do mélos não tem qualquer significado no sentido de melhorar o caráter de quem a estude.

\begin{abstract}
Alguns pensam que a harmônica seja algo de sublime e que seu estudo não apenas o torne músico, mas melhore o seu éthos ( $\beta \varepsilon \lambda T$ Tíous tò ก̃Өo५) - por haver compreendido mal o que dissemos na nossa conferência (B-31, 19-22).
\end{abstract}

$\mathrm{Na}$ passagem do Pseudo-Aristóteles, citada anteriormente, o autor dizia que apenas aquilo que é ouvido tem éthos, porque é o único entre os perceptíveis que tem movimento (Pseudo-Aristóteles, 2001, p. 49). Apenas por esse enunciado não temos como saber se o autor fala de um movimento físico vibratório do som ou de uma sucessão de tons no tempo. Para a harmônica de Aristóxeno, a segunda opção é a que vale e é essa noção de movimento que ele coloca no centro de sua teoria musical: "é no vir a ser que consiste a melodia, assim como todas as outras partes da música" (B-38). O que está em jogo é a construção de uma linguagem musical propriamente dita, sem nenhuma referência exterior. Como dissemos, isso fazia parte da metodologia científica de Aristóteles, ou seja, a ideia de limitação do assunto de uma ciência particular aos seus próprios termos: "Não é possível demonstrar algo fazendo intercâmbio entre gêneros, tal como

${ }^{34}$ Cf. Física, Livro V, Cap. 3, em que Aristóteles analisa a continuidade e a consecução (cf. 226b-227a), como características de coisas físicas que existem no espaço e movimentam-se de acordo com o lugar. 
não é possível demonstrar geometria pela aritmética" (75a,38-40). Também nos Analíticos Posteriores está a noção de que é preciso estabelecer os "primeiros elementos" de uma ciência, em grego, stoikéia. A obra central de Aristóxeno, Elementos de harmônica (Harmonikon stoikeion), inscreve-se nessa linha filosófica. Como aponta Crocker:

Aristóxeno argumenta que um sistema não se torna mais rigoroso quando referenciamos seus elementos a outros elementos fora do sistema (como os números), mas selecionando os elementos mais básicos do sistema, reduzindo-os a um mínimo absoluto, e então deduzindo os outros a partir deles (1966, p. 101-102).

Lloyd sublinha a conexão que havia entre a ideia de prova, no sentido rigoroso do termo, e as stoikeia, elementos ou premissas claramente identificáveis, a partir das quais se desenvolvia 0 argumento dedutivo. Ele diz que desde a obra de Hipócrates de Quios, por volta de 430 a.C., a tentativa de sistematizar a matemática "dependia das decisões a respeito do que tomar como elementos" (1987, p. 75-6). Tanto na lógica formal de Aristóteles quanto na prática sistemática de Euclides havia o que Lloyd chama de um "novo estilo de sabedoria" (1987, p. 146), em que as demonstrações caminham por meio de argumentos dedutivos rigorosos partindo de axiomas. Do mesmo modo, Aristóxeno organiza a sua ciência musical em elementos para deduzir uma teoria.

Na harmônica aristoxeniana, a classificação dos intervalos em consonâncias ou dissonâncias não dependia de argumentos advindos da aritmética, mas daquilo que ele nomeou "propriedade da oitava". Max Weber explica essa propriedade como uma "identidade em outro grau": 
o acompanhamento de vozes em oitavas (vozes de homens e vozes de meninos ou mulheres) é um fenômeno universalmente difundido, tendo sido familiar também à Antiguidade. A oitava, ao que parece, é sentida, por toda a parte onde é encontrada, como identidade em outro grau (1995, p. 105).

Para Aristóxeno, a propriedade da oitava tem uma consequência muito importante que é a inclusão de outros intervalos no conjunto das consonâncias, pois ela faz com que qualquer intervalo consonante ao qual seja acrescentada uma ou mais oitavas se mantenha consonante. $\mathrm{Na}$ teoria musical pitagórica apenas a dupla oitava e a 12a: quinta+oitava entravam no quadro geral das consonâncias. A partir da propriedade da oitava, a quarta+oitava (11 a) passava a constar entre elas. O intervalo não poderia ser considerado uma consonância para os pitagóricos porque a sua expressão matemática, 8:3, não era nem uma razão múltipla nem epímora. Isso soava estranho à lógica aristoxeniana, que dizia que os argumentos pitagóricos eram confusos. Aristóxeno toma como princípio axiomático a consonância, tal como se apresenta de maneira inequívoca ao ouvido:

Para o músico, a exatidão da percepção sensível está quase na ordem de um princípio. Tanto é verdade que é impossível, quando não se tem o ouvido treinado, falar corretamente sobre aquilo que não se percebe $(B-33,21-26)$.

A partir desse postulado, ele desenvolve uma lógica rigorosa de argumentação. O músico está no centro da harmônica e a sua prática tem dois aspectos: a escuta ( $\dot{\eta}$ ákouǹ) e o discernimento, ou

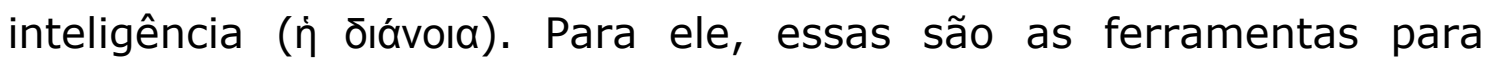

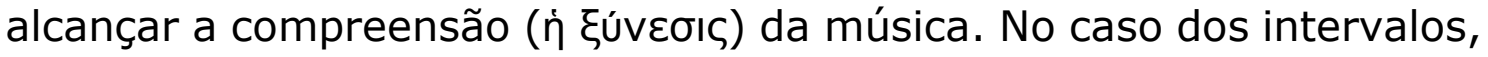
ele defende que a escuta julga o seu tamanho, a sua grandeza, e o discernimento, as suas funções: 
(...) é preciso habituar-se ( precisa e não dizer como costumam fazer aqueles que constroem os diagramas: seja esta linha reta! Pois o geômetra não precisa da função da sensação (...) mas mais o técnico ou aquele que trabalha no torno e outras coisas técnicas (B-33, 10-21).

Para o tarentino, a harmônica precisa da sensação e não pode se basear apenas nos sistemas abstratos, pois ela é uma atividade técnica que consiste em avaliar pela percepção auditiva e compreender a função daquilo que foi percebido. Esse último exercício tem de ocorrer devido ao aspecto relativo da música que compara sucessivamente os tons que ocorrem no tempo.

Creese detecta uma contradição na passagem acima, pois, em outros momentos, Aristóxeno defende que os músicos deveriam treinar a percepção sem o auxílio de instrumentos, mas nessa passagem seu relacionamento com os instrumentos deve ser como a do carpinteiro (cf. Creese, 2012, p.62-3). Creese avança mostrando que, na obra aristoxeniana, a proposta de um procedimento de medição do intervalo de quarta por outros intervalos menores não poderia ser feita sem a mediação de um instrumento, apesar de Aristóxeno não mencioná-lo (cf. Creese, 2012, p.53-54). Como já dissemos, isso não significa que ele, o monocórdio, não existisse.

Apesar de Aristóxeno não confiar nos instrumentos para a constituição da harmônica, o autor não deixava de se interessar por eles pois, como vimos, ele escreveu livros sobre o aulós e sua técnica de perfuração. Mas no âmbito da mélos epistéme, ele reafirma que os instrumentos não estão em condições de demonstrar nada pois "não há nada mais que erro e incerteza na fabricação do aulós, no seu mecanismo e na sua natureza particular" (B-41,12). Aristóxeno não abandona a proposta aristotélica: os instrumentos são objetos inanimados, produzidos por um organopoiós, e só ganharão vida nas mãos de um músico. Como diz Bélis 
o aulós e a lira são objetos de julgamento e não podem ser autoridade e fim; as cordas da lira e as perfurações do aulós não se afinam por si, a afinação requer a operação de um músico, cujo ouvido escuta e julga os sons produzidos (Bélis, 1986a, p. 61-62).

A construção da ciência harmônica de Aristóxeno passa pela identificação de um conjunto de sons estáveis e organizados do mesmo modo como era para Aristóteles a condição do discurso científico: "A aquisição inicial do conhecimento não ocorre pelo vir a ser; pois, de acordo conosco, a razão conhece e pensa por meio do repouso e da imobilidade" (Física, Livro VII). Por serem instáveis na geração dos tons, os instrumentos não poderiam ser confiáveis.

$\mathrm{Na}$ concepção aristoxeniana, não há necessidade de instrumentos para fazer verificações, pois "não há erro maior e mais absurdo que fundamentar em um instrumento a natureza da harmonia

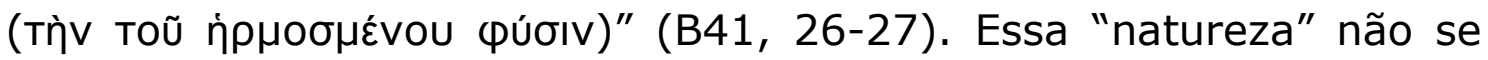
vinculava às propriedades físicas do som; o intuito de Aristóxeno é investigar os tons tal como organizados dentro do sistema musical grego. A harmônica de Aristóxeno está relacionada à natureza da téchne, tal como definida por Aristóteles no Livro II da Física, quando ele fala de duas acepções de phýsis.

Este então é um modo de falar da phýsis: como a matéria subjacente (ǔ $\lambda \eta)$ a cada princípio de movimento e mudança. Outro modo é como

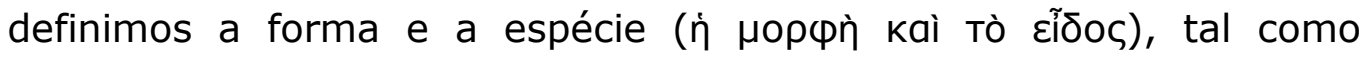
chamamos de téchne aquilo que é de acordo com a téchne e os artefatos técnicos; e chamamos de phýsis aquilo que existe de acordo com a phýsis e são físicos (193a, 28-34).

O artefato técnico, na obra de Aristóxeno, é a própria música. Ele trata a harmônica como uma epistéme, mas rejeita a aplicação da matemática para a sua compreensão e também não considera 
importantes os experimentos acústicos. As ferramentas dessa epistéme são a aisthesis e a diánoia. Assim como as razões numéricas pitagóricas, a natureza do mélos aristoxeniano era uma construção racional. Apesar de serem concepções distintas, ambas integravam o mesmo quadro geral que tinha como ponto de referência a natureza para elaborar os seus princípios. De um lado, a natureza da phýsis, e, de outro, a da téchne. Aristóxeno relacionou as propriedades do som musical à percepção humana, já os pitagóricos buscaram os padrões intrínsecos de sua estrutura. Em ambas, as consonâncias são o elemento unificador dos sistemas. É possível que Aristóxeno concordasse com a acústica matemática pitagórica, mas o objeto de preocupação da sua harmônica não se constituía a partir do eidos platônico ou da hýle aristotélica. A harmônica de Aristóxeno efetivamente não se situa nem no campo das ciências matemáticas, nem no das ciências naturais pois, para ele, a natureza do mélos nada tem a ver com a física aritmética ou com o estudo da produção, emissão, propagação ou audição do som. Ela ocupa um espaço especificamente musical - por que não dizer, técnico. Ele descreve a regularidade do processo de desenvolvimento do mélos.

Aristóxeno será o responsável por fixar a terminologia da harmônica. Por exemplo, tásis será o lugar em que há uma prolongação e estabilidade da voz (que nós modernamente chamamos altura da

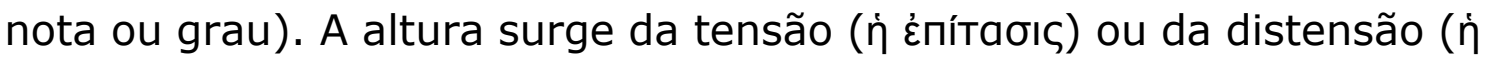

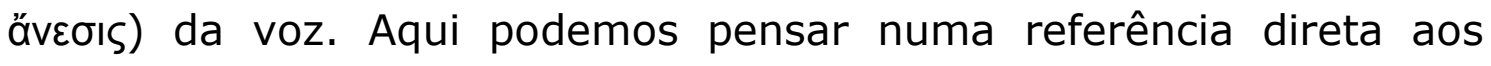
instrumentos musicais, uma vez que tensionar ou distender são termos advindos da afinação dos instrumentos. Contudo, para Aristóxeno, tensão e distensão são causas, respectivamente, da qualidade aguda e grave dos tons. Ele substitui os antigos termos alto (ầv $\omega$ ) e baixo

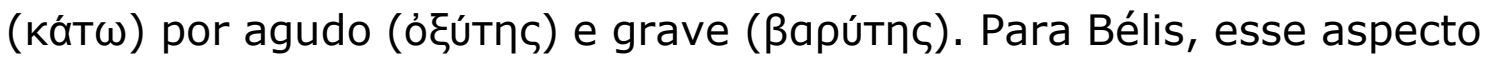
demonstra um afastamento da prática instrumental, haja vista que alto e baixo referiam-se às posições das mãos nas cordas dos instrumentos. Em tal caso, alto, poderia não ser agudo, como a nós pareceria, mas 
grave, por estar se referindo a uma corda mais longa e mais distante do músico, numa harpa. E vice-versa. Isso demonstraria uma intenção da teoria aristoxeniana de denunciar a instabilidade dos antigos termos, fundada na prática instrumental (cf. Bélis, 1986a, p.176-77).

A questão da instabilidade dos instrumentos na obra aristoxeniana suscita a pergunta a respeito de onde ele acha que partiriam tons realmente confiáveis. Se a resposta for da voz humana, podemos observar aqui a origem de um dos focos de debate que aflorará na Renascença acerca da distinção entre música natural, produzida pela voz humana, e música artificial, gerada pelos instrumentos. Na filosofia natural aristotélica, é a epistéme qe revela o nexo causal dos eventos, sejam eles naturais ou técnicos.

Igualmente importante para a teoria musical do ocidente é a noção aristoxeniana de dois tipos de movimentos melódicos: de acordo com o tempo (katà tóv Xpóvov) e de acordo com o lugar (кaTà Tóv Tónov). A rítmica ocupar-se-ia do primeiro movimento, e a harmônica, do segundo, dando origem à noção de tessitura, âmbito ou ainda extensão. Rocconi faz uma observação a respeito de outra obra de Aristóxeno da qual temos uma parte substantiva, Elementa ritmica.

Pela primeira vez, o ritmo musical é descrito como algo independente e não inerente à estrutura silábica, graças à referência a uma unidade de tempo mínima à qual o performer deve emparelhar cada uma das notas, o prótos chrónos (Rocconi, 2012, p. 65).

Essa distinção teórica do ritmo é mais um elemento da construção aristoxeniana que concorrerá para a autonomização da música, que só ocorrerá completamente no século XVIII. A abordagem epistemológica da harmônica passava pelo entendimento das formas de atuação da percepção musical, mas também de outra faculdade cognitiva, a memória. A música é um fenômeno que acontece no tempo, portanto, para compreendê-la, "é necessário perceber (ouvir) 
o que transcorre e lembrar o que transcorreu" (B-39, 1-2). Essa dupla percepção da noção rítmica aprofunda o campo de conhecimento da harmônica e a autonomia que busca Aristóxeno valoriza a prática instrumental da música de seu tempo, um passo importante em um debate de longa duração na filosofia da música ocidental.

Outra postura da filosofia aristoxeniana que terá ressonâncias posteriores é a proposta de uma distância homogênea entre os intervalos, posição precursora do temperamento igual. Aristóxeno não desenvolve na Harmônica a questão do meio-tom, limita-se a enunciála, mas ela será explorada por autores posteriores, entre os séculos II e IV d.C. como Cleônides, autor do livro técnico Harmonica introductio, e Aristides Quintiliano, em seu De musica (cf. Mathiesen, 1999, p. 52). Na segunda metade do século XVI, com a tradução da obra de Aristóxeno para o latim, a divisão do tom voltará a ser intensamente debatida por músicos e teóricos renascentistas, em especial, Gioseffo Zarlino e Vincenzo Galilei. ${ }^{35}$

O tarentino não se refere a comprimentos de corda, mas a partes da escala pois não é a partir do aspecto material da corda e de suas ressonâncias que se constrói a harmônica aristoxeniana, mas dos elementos da linguagem musical tal como se apresentam na voz ou nos instrumentos. O que importa é observar a regularidade do processo do mélos, para Aristóteles, sua causa eficiente e não, como já poantado, sua causa material ou formal. A escala não é dividida em números discretos, pois é vista como contínua. Assim, não há nenhum impeditivo para a divisão do tom, pois sendo ele a diferença de grandeza entre a quarta e a quinta, sua divisão pode ser "a metade,

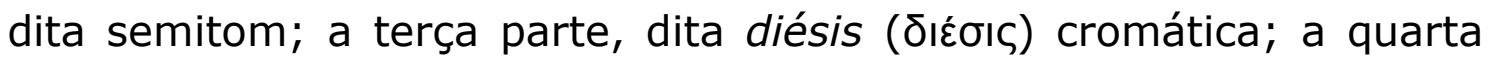
parte, dita mínima diésis enarmônica" (B-46, 2-6).

Quando Aristóxeno define os intervalos musicais em termos de distâncias, ele o faz sem referências às razões aritméticas. Para ele,

\footnotetext{
35 A primeira tradução dos Elementos de harmônica de Aristóxeno foi editada em latim em Veneza, no ano de 1562. A segunda, em italiano, é de 1593, e foi editada em Bolonha.
} 
um intervalo de quinta não é representado pela razão $3: 2$, mas como 3 tons e meio. Os tons que compõem um intervalo são comparados pela distância em termos geométricos, tal como dois pontos em uma reta. Isso fará com que o intervalo de meio-tom, proscrito pela aritmética pitagórica, torne-se perfeitamente viável, desde que percebido.

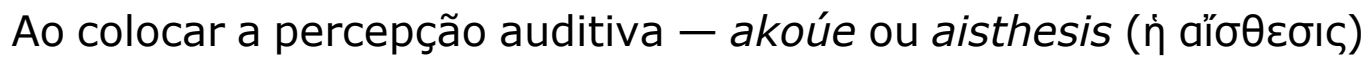
- no centro da sua harmônica, Aristóxeno refuta facilmente os argumentos pitagóricos. A sua definição da propriedade da oitava derruba a suposição pitagórica da relação entre as consonâncias e as razões serem compostas apenas com os quatro primeiros números inteiros. Se não contestou o modelo de harmonia universal diretamente, a teoria aristoxeniana desequilibrou alguns de seus pilares especificamente no campo da música, com o argumento de que a classificação dos intervalos em consonâncias ou dissonâncias não dependia da aritmética.

Em Elementos de harmônica, está descrito o sistema de combinações de tetracordes conjuntos e disjuntos, tal como utilizado na música grega do século IV a.C. Aristóxeno o chama de Grande Sistema Perfeito e, segundo Rocconi, essa é a descrição mais antiga de um sistema de escalas completo. Gibson observa a respeito da teoria aristoxeniana que "sua ambição de confiar nos primeiros princípios e na demonstração a fim de estabelecer os teoremas da ciência é minada pela própria natureza da música" (2005, p. 73). Para Gibson, essa "natureza" da música implicaria em reconhecer a tensão existente entre aquilo que é universal ou natural - os sons e seus harmônicos - e cultural - os sistemas musicais. O tarentino aborda essa questão quando critica os chamados harmonicistas, músicos que elaboravam extensos diagramas colocando todas as possíveis combinações de notas, derivando essa notação de sua prática instrumental, especialmente do aulós. Para ele, esse conhecimento não tinha estabilidade. 
A doutrina dos harmonicistas sobre as tonalidades é análoga ao modo como se contam os dias dos meses: assim, por exemplo, quando para os coríntios são dez, para os atenienses são cinco e ainda para outros oito (B-37,14-17).

Aristóxeno reclama desses músicos harmonicistas que ofereciam

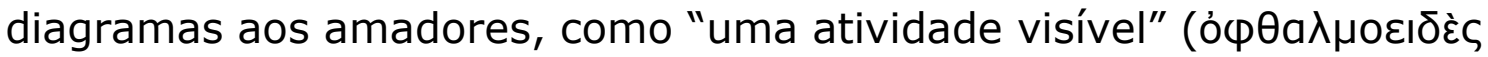
ع̃pyov). Para ele, essa notação musical mostrava apenas o tamanho dos intervalos e já haviam sido apresentados argumentos mostrando que conhecer o tamanho dos intervalos representava apenas uma parte da música. Aristóxeno diz que eles invertem a ordem da apreensão, pois em vez da auditiva e da intelectual, feita pela aísthesis e pela diánoia, colocam a relevância no que aparece ao olho e o princípio da harmônica aristoxeniana tem de ser auto-evidente, auditivamente. Fica claro que a mélos epistéme não é para amadores, mas para aqueles que tem condições de observar corretamente o fenômeno.

Como em toda epistéme que consiste em várias proposições, e em que o caminho correto é encontrar alguns princípios a partir dos quais é possível deduzir as verdades dependentes, nós temos de nos conduzir em nossa seleção de princípios por duas considerações. Primeiramente, cada princípio deve ser verdadeiro e evidente; em segundo lugar, ela deve ser aceita pela aisthesis como uma das primeiras partes da harmônica. Pois o que requer demonstração não é um princípio fundamental; e em geral temos de tomar cuidado para não sairmos fora do caminho da nossa ciência, como os que olham o som visto como uma vibração de ar, e não sair do trilho abandonando o que de fato pertence à harmônica (B 44, 4-16).

Aristóxeno busca compreender a ordem intrínseca da harmônica sem o recurso da leitura visual dos fenômenos auditivos por perseguir 
um enorme rigor epistemológico. Mas ele mesmo sabe que os próprios músicos estão sujeitos a erros em suas avaliações. Como lembra Bélis, "ele reprova em outro momento os músicos que abandonam o gênero enarmônico por não conseguirem distinguir o quarto de tom, levandoos a abandonar o mais belo entre os gêneros" (Bélis, 1986a, p. 206).

$O$ aperfeiçoamento dos instrumentos possibilitou uma expansão das capacidades de formulações teóricas da música e, ao mesmo tempo, a sistematização teórica da música tal como empreendida por Aristóxeno construiram as bases de sustentação da sua autonomia.

Aristóteles define nos Analíticos posteriores, o princípio da téchne e o da epistéme: "A partir da aísthesis surge a mnéme ( $\mu \vee \eta ́ \mu \eta)$ e a

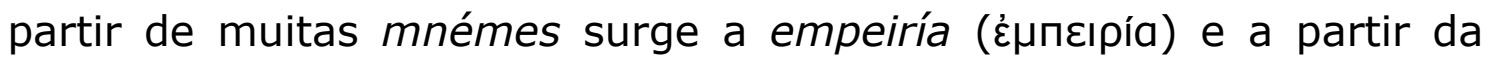
empeiría surge o princípio de técnica - se for concernente ao vir a ser - ou ciência - se for concernente ao que é" (100a,3-9]. Resta-nos compreender se os princípios da téchne convergem para os da epistéme.

\subsection{A convergência de matemática, acústica e mecânica}

A postura de Aristóxeno pela primazia da discriminação auditiva e a recusa metodológica dos recursos visuais será inglória. O desenvolvimento da notação musical, a expansão dos diagramas, a representação espacial das estruturas intrínsecas da música feita pela ciência pitagórica foram conquistas inequívocas da música ocidental. Muitas dúvidas já foram levantadas quanto ao valor epistêmico de diagramas, mas as formas de visualização foram caminhos para novas práticas hermenêuticas e criativas.

A força da argumentação aristoxeniana obrigou aos defensores do modelo pitagórico reforçarem suas posições. Talvez a teoria mais eloquente a esse respeito esteja no tratado Divisão do cânone (Katatouǹ kavóvos), cujo autor costuma ser referido como pseudoEuclides, por apresentar similaridades com o estilo de argumentação do matemático Euclides de Alexandria, contemporâneo de Aristóxeno. 
O tratado pode ser visto como uma reação da escola pitagórica na defesa de seus princípios, mas ele revela que o pitagorismo também tinha um dinamismo próprio. Isso será enfatizado pela presença de uma ferramenta, o cânone, na qual era possível ver e ouvir, simultaneamente, as razões musicais. O cânone mais simples era o monocórdio. Ele tinha um cavalete móvel, hypogogía (ùnoyoyía), que percorria uma prancha em que estava fixada uma única corda. As marcações das divisões matemáticas na prancha deveriam corresponder auditivamente aos intervalos musicais investigados.

Entre os estudiosos, não há consenso a respeito do início da utilização do cânone, ou monocórdio, pelos pitagóricos. Assim, não sabemos se Aristóxeno, na passagem em que se refere a um ophtalmoeidés órganon (cf. Aristóxeno, B 40-41), está falando dele. Repetimos, se é difícil rastrear alguma evidencia da existência do monocórdio antes de 300 a.C., ano de morte de Aristóxeno, não podemos esquecer que a obra Divisão do cânone é sua contemporânea, então não há razão para duvidarmos que uma ferramenta como essa não existisse. Além disso, os fragmentos de Arquitas que se referem ao cálculo das médias proporcionais para encontrar com precisão os intervalos de quarta e quinta, seriam muito fáceis de serem apresentados em um monocórdio.

Apesar do rigor aritmético com que construiu a prova das razões epimóricas, Arquitas parece ter se inclinado mais aos fenômenos que seus predecessores pitagóricos, e bem mais do que gostaria Platão que, na República, deixa claro que a investigação da harmônica não deveria voltar-se para o mundo sensível.

O comportamento deles é ridículo (...) esticando os ouvidos como que para ouvir a conversa dos vizinhos, alguns deles dizendo que conseguem ouvir um som entre dois, (...) colocando os ouvidos antes da mente. Você está falando - eu disse - daquelas pessoas que 
torturam as cordas do instrumento esticando-as com as cravelhas para interrogá-las (531a-c).

Por seu turno, Arquitas fala do discernimento que os estudiosos devem ter acerca da natureza de cada uma das coisas, iniciando a investigação pelo todo para depois investigar as coisas separadas. No caso da harmônica, isso significa que ele irá expor primeiro as características do som: sua origem pelo impacto, plégue (í $\Pi \lambda \eta ү \hat{n})$, a relação entre velocidade de movimento e altura e sua propagação. Em seus exemplos a respeito da relação entre velocidade, pressão do ar e altura são mencionados instrumentos musicais:

No aulós o ar lançado da boca que chega aos orifícios mais próximos dela e por causa da grande força emite um som mais agudo; mas, chegando aos orifícios mais distantes [a nota é] mais grave. Assim, é evidente que o movimento rápido produz o som agudo e o lento, o grave. Assim como nos rhómboi, que giram nas cerimônias dos Mistérios o mesmo acontece: movidos lentamente, produzem um som grave; com força, agudo (DK 48, B1]).

Arquitas tem interesse pela natureza física do som e por isso ele parece estar mais próximo das ideias da Divisão do cânone, em que os elementos da teoria musical matemática são antecedidos pela acústica, ou melhor, pelo silêncio.

Se há repouso e imobilidade, deve haver silêncio. Se houver silêncio e nada se mover, nada se ouve. Se algo for ouvido, é necessário que antes haja impacto e movimento. Assim, todas as notas (ò фӨóyYoৎ) surgem devido ao impacto (Pseudo-Euclides, 1991, p. 115).

A partir da definição das notas como movimento, o tratado argumenta que, se esse for mais rápido, a nota será mais aguda e, vice-versa, se o movimento for mais lento, o tom será mais grave. Se 
esses sons tiverem uma altura precisa, como uma nota musical, será possível descrever os intervalos entre eles como razões numéricas. Sabemos que não é possível ao olho humano perceber esses movimentos, muito menos identificar suas partes, mas na obra elas têm um número, pois a sequência de movimentos possui partes. Assim, distender ou tensionar as cordas para afiná-las será subtrair ou somar partes desses movimentos.

Após abordar a natureza do som e das notas e também definir aritmeticamente a consonância e a dissonância, o tratado apresenta um guia para a localização das notas e das razões musicais matemáticas no cânone. Trata-se de um aperfeiçoamento da teoria musical de Arquitas na medida em que apresenta a ferramenta para a sua verificação.

Arquitas colocava a logística como a principal das mathémata. Como diz Huffmann, para ele,

o cálculo e a ciência na qual está baseada a logística estão acima de tudo focadas na proporção, então devemos conjecturar se Arquitas estaria defendendo que a proporção não é útil apenas para buscar e descobrir definições; ela é a chave para procurar e descobrir todo e qualquer conhecimento (2010, p. 76).

Esse papel produtivo que Arquitas dava à proporção explica seu método das médias proporcionais. A partir do cálculo do intervalo de quinta pela média harmônica toda a escala era montada no interior de uma oitava. Esse pensamento é geométrico pois, quando os valores quantitativos se modificam proporcionalmente, não há alteração na configuração das relações. Arquitas foi, de fato, considerado um dos grandes geômetras de seu tempo e, segundo Huffman, elencado por Eudemus de Rhodes, discípulo de Aristóteles, como um dos três principais da geração de Platão, ao lado de Teeteto de Atenas e Leodamas de Thaus (cf. Huffman, 2010, p.5). Um dos motivos da sua 
fama teria sido uma solução que ele apresentou para o problema da duplicação do cubo, que sobreviveu em citação de Eutócio na obra Comentários sobre "A respeito do cilindro e da esfera de Arquimedes" (cf. Huffmann, 2010, p. 342-401). Para Huffman,

A descoberta de como encontrar as duas médias proporcionais que resolvem o problema da duplicação do cubo é de importância enorme para a mecânica, na medida em que a solução desse problema permite a alguém não apenas dobrar o cubo, mas construir corpos sólidos maiores ou menores que outro corpo sólido em qualquer razão (Huffman, 2010, p. 80).

Não era incomum a filosofia natural antiga utilizar a mecânica como analogia na investigação de campos como a medicina e a astronomia, embora tenhamos de tomar o cuidado para não confundir essa utilização com qualquer postura mecanicista, que seria anacrônica. Na Física, Aristóteles relaciona as "mais físicas dentre as matemáticas" como sendo a óptica, a harmônica e a astronomia (194a7); em Analíticos posteriores ele subordina a óptica à geometria, as observações do céu à astronomia, a harmônica baseada na audição à harmônica aritmética, e a mecânica à geometria sólida (apud Barker, 1989b, p. 71 [78b 34]).

É possível considerarmos que a mecânica já fosse um campo de investigação no tempo de Aristóteles, e muitos autores consideram que Arquitas tenha sido um dos primeiros a tratar da disciplina. De acordo com Huffman, nesse sentido, apenas dois dos antigos testemunhos podem ser tomados como confiáveis: "a afirmação de Diógenes Laércio de que Arquitas trabalhou em matemática relevante para a mecânica e a pomba de Arquitas" (2010, p. 83 ).

Os relatos a respeito da pomba, no entanto, não explicam se ela tinha uma propulsão interna ou apenas poderes divinos, portanto, como observa Berryman, não há de fato uma explicação mecânica a 
respeito de seu funcionamento. A autora levanta a hipótese de que a suposta pomba de madeira que voava pudesse ser uma espécie de catapulta, afinal era comum os dispositivos antigos ganharem nomes de animais e tendo sido o filósofo um general associado ao arsenal de Dionysius, cujos engenheiros recebiam muita atenção, isso tornar-seia uma possibilidade. De qualquer modo, não é possível confirmar nada a esse respeito. Assim, ainda seguindo Berryman, essa referência à pomba de Arquitas diz muito pouco a respeito de um funcionamento mecânico de fato e mais sobre o maravilhamento causado por um artefato (cf. Berryman, 2003, p. 354-5).

Mas é importante perceber que, nessa narrativa da pomba de Arquitas, o filósofo não é chamado de artesão. Ele não produz esse artefato para o comércio, portanto, não é um bánausos. Se ele o tiver construído de fato, toda a ênfase estará na solução que permitiu ao artefato voar e não exatamente em como foi feito, na sua técnica de construção. No período helenístico, alavancado pelo patronato dos Ptolomeus, haverá uma profusão de dispositivos técnicos feitos para mostrar princípios da mecânica como forma de entretenimento. Seus inventores, em geral, não serão os seus construtores. De qualquer modo, Arquitas demonstra uma postura precursora, enxergando no trabalho dos artesãos e dos técnicos um caminho para o conhecimento da natureza.

Crombie vê tanto a investigação científica quanto a composição artística como "artes cognatas do solúvel" que colocam em operação sugestões vindas da imaginação analítica e da construtiva (cf. Crombie, 1990, p.161-73). Falando do período renascentista, o autor comenta que nesse momento arte e ciência "começam a considerar que a análise teórica e o design racional precedem a construção material" (1990, p. 165). No período helenístico há um movimento semelhante, pois, nessa atividade de solução de enigmas, começam a surgir concepções e explicações mecânicas que se voltam para os campos de estudo da filosofia natural. 
Como vimos, no tratado Divisão do cânone, havia sido apresentada uma teoria acústica do som e do tom musical. Essa investigação acústico-matemática não considera nenhum aspecto da natureza do mélos, tal como investigada por Aristóxeno, que tratava a música quase como um organismo vivo. Para Aristóxeno, a harmônica é uma ciência natural e seu objetivo é revelar a ordem natural subjacente, não das vibrações sonoras, nem dos instrumentos artificiais, mas aquela ordem "natural" que leva a voz a localizar e cantar determinados intervalos: "é claro, a partir de tudo que foi dito,

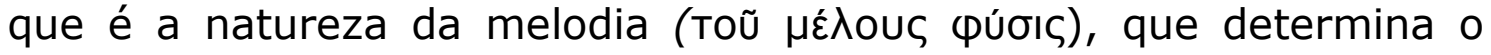
menor intervalo consonante, o de quarta" (Aristóxeno, A21,13).

A harmônica aristoxeniana volta-se para a natureza do mélos; como vimos, na segunda acepção de natureza para Aristóteles. A primeira acepção corresponderia ao som. A harmônica não tem em si mesma o princípio de seu próprio fazer, se não há músico, não há harmônica, mas há som.

Pois o arranjo artificial feito pelo artesão é meramente um incidente que ocorreu a ele [em nosso caso, o mélos ou um instrumento musical] enquanto que a sua essência e qualidade natural deve ser encontrada naquilo que persiste continuamente através de tais experiências [0 som ou ao material de que é feito um instrumento musical]. (192b).

Apesar da distinção, o télos do processo artificial é assimilado ao natural, pois, na medida em que os processos artificiais têm uma finalidade, a relação do antecedente com o consequente é igual para a phýsis e para a téchne. Nesse sentido, as formulações aristotélicas podem estar olhando adiante, para uma ou duas gerações. No período helenístico, tanto a "maravilhosa ordem da melodia harmonizada" (B $42,17)$ como produto da téchne possui a sua mélos epistéme, quanto o som tem a sua investigação acústica. 
O tratado Divisão do cânone indica uma tendência da harmônica da época em trazer os argumentos para um campo quantitativo e de apresentar experimentos em instrumentos. Uma outra vertente da especulação musical do período helenístico vai em uma direção diferente. Ela já havia sido explorada por autores como Teofrasto de Eresus, aluno de Aristóteles, e com quem Aristóxeno rivalizou na sucessão da direção do Liceu. Parte significativa da obra sobre música de Teofrasto se perdeu e ela não foi tão importante para a sistematização e autonomização da harmônica como a de Aristóxeno. No entanto, Teofrasto aponta elementos importantes, na medida em que defende que as diferenças tonais da música, apesar de seguirem determinadas leis quantitativas, adviriam também de uma base qualitativa como a intensidade da voz no canto, as dimensões do tubo do aulós e a densidade das cordas (cf. Schueller, 1988, p.82). Daí a importância que deu à descrição da confecção das palhetas, por exemplo.

Esse olhar sobre a instância material do som está presente em um dos mais importantes textos para a história dos instrumentos musicais do período helenístico, conhecido como De audibilibus (EK тoũ

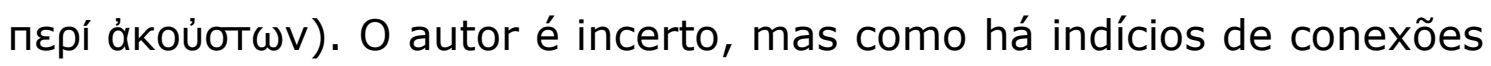
de suas ideias com as da escola peripatética, a obra costuma ser referida como de autoria do Pseudo-Aristóteles. No tratado, não há explicações aritméticas ou geométricas. Na visão do autor, "os sons permanecem similares em caráter a suas fontes geradoras" (PseudoAristóteles, 1989, p. 106), indicando que as qualidades audíveis relacionam-se às qualidades tangíveis, conclusão bem diferente daquela do modelo matemático e também da harmônica aristoxeniana.

Seu interesse principal é com a voz humana, que poderíamos chamar "natural", na primeira acepção de natureza de Aristóteles mencionada anteriormente. Mas, como na voz é mais difícil observar os mecanismos de produção e transmissão do som, o autor faz analogias com instrumentos musicais a fim de esclarecer elementos da 
acústica, ou seja, abordando a música por um viés diferente do das consonâncias e dissonâncias. As discussões estão baseadas em analogias entre a voz humana e os instrumentos musicais, com menções também aos sons da natureza e a máquinas, como as catapultas. Além disso, o autor discute a fisiologia da emissão vocal, as causas das várias modificações nas qualidades perceptíveis do som (distância ou proximidade, brilho, claridade, opacidade, aspereza) e modos de produção do som nos instrumentos.

$O$ tratado descreve as diferentes formas de recipientes envolvidos na produção do som, principiando pelo corpo humano: a boca, a traqueia e o pulmão. Este último, tal como o fole, não pode ser pequeno, denso e duro, se quiser lançar o som a uma longa distância, tal como "as catapultas não podem lançar a grandes distâncias, se suas cordas estiverem rijas" (Pseudo-Aristóteles, 1989, p. 100).

Outra seção do De audibilibus versa sobre o tratamento que se deve dar aos chifres de animais, kéras, os quais podem ser soprados diretamente ou encaixados no final de tubos de instrumentos de sopro a fim de ampliar sua capacidade de ressonância, como vimos aparecer no aulós frígio. A recomendação é que eles sejam cozidos para que atinjam a ressonância desejada.

Cozinhar os chifres contribui enormemente para a suavidade do som, pois aqueles que foram cozidos tem uma ressonância mais próxima dos vasos de cerâmica, devido à resistência e à secura produzidas pelo fogo (Pseudo-Aristóteles, 1989, p. 104).

Para o autor, quanto mais reto for o oco do chifre, melhor, pois quando o som se desloca, ele não deve encontrar nenhuma obstrução, senão a ressonância será abafada. Ele ilustra a tese com a forma de testar os mastros de um navio pelo som. 
Quando se bate de um lado do mastro de um navio, a ressonância viaja continuamente até o outro lado, a não ser que a baliza esteja rachada, nesse caso o som avança até certo ponto, dispersa-se e desaparece (Pseudo-Aristóteles, 1989, p. 104).

Em outra passagem, o escritor faz advertências sobre a qualidade das cordas e também das palhetas dos aulói, com o objetivo de melhorar seus timbres. Para os intérpretes, são fornecidas orientações no sentido das variações de timbres que devem ser obtidas nos instrumentos, de acordo com o que for exigido em uma circunstância de performance. Como no caso da sálpinx que é bastante utilizada em contextos marciais, porém, se for tocada em uma festa, deve-se "relaxar a tensão do sopro, para tornar o som o mais suave possível" (Pseudo-Aristóteles, 1989, p. 106).

Em alguns momentos do De audibilibus, se não fosse pelo estilo e pelos nomes dos antigos instrumentos, poderíamos imaginar um autor discorrendo hoje sobre a técnica de modelagem física - técnica de simulação de instrumentos musicais que utiliza um algoritmo para computar o comportamento das formas de onda sonora e reproduzi-lo. Como no exemplo a seguir.

Assim, as cordas torcidas de maneira apertada produzem sons mais duros, tal como os chifres quando cozidos. Se alguém dedilha as cordas violentamente e não suavemente, elas darão uma resposta igual e necessariamente mais violenta. Cordas que não foram muito apertadas e chifres que não foram muito cozidos produzem sons mais suaves e, do mesmo modo, os instrumentos de maiores proporções. Pois os golpes no ar são mais lentos e suaves devido ao tamanho dos espaços envolvidos, enquanto que aqueles que são produzidos por instrumentos menores são mais duros devido à tensão das cordas. É evidente que um som de um instrumento é mais áspero quando se tange as cordas em um lugar que não seja o meio delas, pois as partes da corda que estão mais próximas do estandarte ou das cravelhas 
apresentam-se sob uma tensão muito maior. Instrumentos feitos de madeira mais macia produzem sons mais suaves, pois os sons chocando-se contra algo macio, não repercutem com a mesma força (Pseudo-Aristóteles, 1989, p. 106).

Assim, os fragmentos do De audibilibus representam uma modificação profunda na abordagem da acústica, com reflexos na área musical. A explicação da música já não está apenas nos números ou nas consonâncias, mas em tudo que a compõe.

Apesar de a obra ter elementos da escola peripatética, também podemos ver nela traços do ceticismo, um dos movimentos filosóficos do período. Essa filiação seria possível se considerássemos a aplicação do ceticismo à música tal como presente na obra de Sexto Empírico, responsável pela escola cética na sua fase final, no século II d.C. No sexto livro da obra Contra os matemáticos, ele condena o dogmatismo vigente na arte musical, mas deixa claro que seus ataques são contra uma maneira de conceber a música, ou seja, como a ciência da harmônica, "tal como dizemos que Aristóxeno, o filho de Espíndaro, era músico" (apud Treitler, 1998, p. 95). O filósofo cético preserva, no entanto, o fazer musical, ou seja, "a ciência concernente à experiência instrumental, tal como os auletistas, os psalteristas e as mulheres harpistas (apud Treitler, 1998, p. 95)". Tanto a postura cética de Sexto Empírico quanto a teoria física do De audibilibus estão ligadas ao epicurismo representado por Lucrécio, no século I a.C. Na obra De rerum natura, o autor romano descreve aspectos físicos e materiais do som e da voz. Se o som é ar, e o ar é material, a música pode ser produzida de maneira mecânica.

O interesse de Aristóteles pelas regras de proporcionalidade para alavancas simples e pela força paralelograma pode ser uma herança e um desenvolvimento da filosofia de Arquitas. Se juntarmos isso a algumas preocupações que ele e seus discípulos tiveram com a a 
música e o som, apesar de alguns tropeços, podemos creditar à sua influência muitos dos avanços do período helenístico. 


\section{Capítulo 5 - A HYDRÁULIS}

\subsection{O desenvolvimento da pneumática}

Alexandria foi fundada no final do século IV, em 323 a.C., mas foi no reinado de Ptolomeu Filadelfo, que se iniciou em 283 a.C., que a cidade se tornou o grande polo de atração dos sábios da época. 0 patronato dos Ptolomeus propiciou uma nova abordagem da produção técnica na medida em que os artífices, não estando mais atrelados às corporações que regulavam a produção ou à necessidade de comercialização de seus produtos, podiam trabalhar nas atividades que quisessem, como a produção de objetos maravilhosos.

As máquinas destinadas ao entretenimento foram uma consequência do desenvolvimento da mecânica, a partir dos trabalhos envolvendo válvulas, bombas, catapultas e dispositivos a vapor. No final do século III a.C., Apolonio de Perga construiu autômatos musicais operados por água corrente, Strato de Lampsacus fez experimentos com tubos imersos em líquido e Arquimedes descobriu o princípio da hidrostática.

Nesse contexto, nasceu um dos instrumentos musicais mais

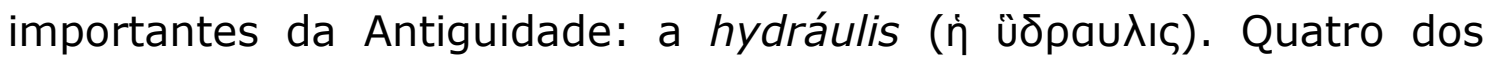
principais nomes ligados a ele foram expoentes da mecânica do período helenístico: Ctesibius de Alexandria (fl. 270 a.C.), Filo de Bizâncio (c. 200 a.C.), Marcus Vitruvius Pollio (c. 25 a.C.) e Hero de Alexandria (c. 60 d.C.).

Ctesibius era filho de um cabeleireiro em Alexandria. Ele escreveu tratados que não sobreviveram, mas sua importância como

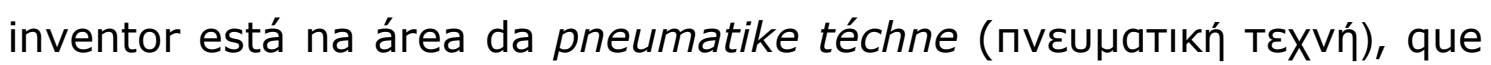
investigava mecanismos acionados por água corrente, vapor e ar comprimido.

Ctesibius empregou a tecnologia de pressão do ar para regular o fluxo da água em diversos dispositivos, aperfeiçoando o relógio de 
água feito para deleitar a rainha Arsinoë, esposa de Ptolomeu Filadelfo, com trompetes altissonantes. Ele é tido como o criador da catapulta pneumática e da bomba com êmbolo e válvula, mas o mecanismo mais famoso de Ctesibius talvez tenha sido de fato a hydráulis. Esse é o único instrumento da Antiguidade grega do qual podemos dizer que teve realmente um prótos eurétes, embora saibamos que sua invenção seja o resultado de uma reunião de conhecimentos acumulados ao longo do tempo, que permitiu que ele fosse criado.

Talvez Ctesibius tenha feito 0 instrumento apenas para demonstrar os efeitos do ar comprimido, mas a transferência dessa tecnologia para um instrumento musical representa um dos saltos mais significativos da música da Antiguidade. Mas isso só aconteceu pela intervenção de um músico e há referências de que a sua esposa, Taïs, passou a tocar muito bem o novo instrumento.

Só é possível conhecer a pnemautica de Ctesibius nos tratados de Filo de Bizâncio, que pode tê-lo conhecido, e de Hero de Alexandria, já no século I d.C. Nas suas obras podemos acompanhar a história da pneumática, desde suas técnicas e princípios mais simples. Berryman observa que, para o desenvolvimento dessa ciência, Ctesibius fez um "procedimento inverso ao da noção de rarefação, das filosofias naturais clássicas, forçando o ar a entrar em lugares menores que ele em geral ocupa" (2009, p. 156).

A hydráulis era baseada no modelo de tubos escalonados da sýrinx. Só que, no instrumento, o ar era forçado a passar pelos tubos pela pressão da água, cada um deles produzindo um tom. Aparentemente Filo assistiu a uma demonstração do instrumento e a sua descrição da hydráulis aparece em um dos volumes que restaram de seu Tratado de engenharia, Mechaniké syntáxis). No livro 5, que trata sobre pneumática, está a descrição mais antiga do instrumento.

Essa aplicação, inventada por Ctesibius, era um arranjo puramente mecânico que fazia uso das leis da natureza. Ele provou, nos teoremas 
pneumáticos (...) que o ar é resistente, elástico e extremamente móvel; e que além disso quando é preso numa vasilha forte cilíndrica pode ser comprimido e subsequentemente se expande rapidamente, jogando para fora todo o volume do cilindro. Com sua vasta experiência em engenharia, Ctesibius rapidamente percebeu que esse movimento [de descompressão] poderia, com a ajuda de bastões articulados conectados, produzir uma tensão muito forte e um ímpeto poderoso. Com isso em mente ele construiu um cilindro, pýxis (nuछ̇́c) no formato parecido com as caixas de medicina dos doutores, sem tampa, feito de bronze fino, de modo que fosse resistente e forte, trabalhou-o no seu estado maleável, como cera, e o forjou para dar a sua resistência. 0 interior dos cilindros foi trabalhado em um torno e a superfície foi polida até ficar lisa, homogênea, muito uniforme. Em seguida, ele inseriu um

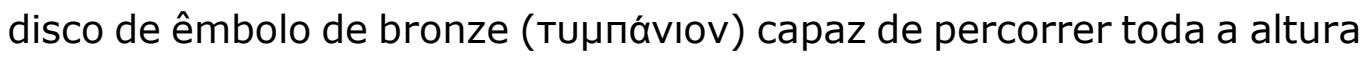
do cilindro enquanto pressionava fortemente sua circunferência, que do mesmo modo havia sido tratada para ser bem lisa e polida, sem vazamento.

Não se surpreendam, portanto, ou duvidem, que tal aparato pudesse ser realmente construído, pois nessa sýrinx que se toca com as mãos e é conhecido como hydráulis, o mecanismo que força o ar para dentro do pnigeus (ó пvıүعúc), hemisfério colocado dentro da vasilha na água, é feito de metal, e forjado da mesma maneira que os tubos cilíndricos que acabei de descrever. Ctesibius provou isso para nós quando ele demonstrou que o ar naturalmente tinha um movimento rápido e poderoso e nos instruiu também no uso dos êmbolos dos cilindros (apud Perrot, 1971, p. 24-5).

O que traduzimos em uma linguagem especializada por cilindro, êmbolo e hemisfério eram termos correntes dos gregos, usados, respectivamente, para uma caixa de guardar objetos, pýxis, um pequeno tambor, tympánion, e um abafador de carvão, pnigeus. Na descrição de Filo, não há números nem termos da geometria, que, como veremos, estão presentes em Hero de Alexandria. O movimento 
de descompressão descrito por Filo é o mesmo que Ctesibius deve ter utilizado nas catapultas de ar comprimido.

A hydráulis descrita por Filo de Bizâncio é bastante simples se comparada às de Hero de Alexandria e Vitrúvio. É possível que ela fosse um protótipo que Ctesibius tenha feito. A construção de protótipos era uma prática utilizada, como comenta o próprio Filo na obra Sobre a construção da artilharia:

É evidente que não é possível chegar a uma solução completa dos problemas envolvidos meramente pela razão ou pelos métodos da mecânica, e que muitas descobertas podem ser feitas apenas como um resultado de testes (apud Lloyd, 1973, p. 99).

A descrição de Hero segue a de Filo, mas com mais precisão de detalhes. As figuras são indicadas por letras como em desenhos geométricos. Considera-se que Hero tenha vivido no século I d.C., portanto em um contexto bem diferente da cidade de Alexandria em que viveu Ctesibius. Nas suas Pneumaticas, a hydráulis aparece na parte final do tratado como um dos últimos dispositivos descritos e mostra a coordenação de vários procedimentos demonstrados anteriormente, trabalhando em conjunto para um único resultado. $O$ manuscrito mais antigo que temos da obra, de Veneza, é de 1250.

$\mathrm{Na}$ obra, artefatos com utilidade na medicina como a seringa ou em atividades como o controle de incêndios figuram ao lado de brinquedos e autômatos musicais. Na Introdução, Hero distingue os campos da filosofia natural e da mecânica e em seguida explica os objetivos dos instrumentos úteis e os de encantamento.

A investigação das propriedades do ar atmosférico foi considerada merecedora de atenção pelos antigos filósofos e mecânicos, os primeiros deduzindo-os teoricamente, os últimos a partir da ação dos corpos sensíveis. (...) Pela união do ar, terra, fogo e água, e pela concorrência de três, ou quatro princípios elementares, várias 
combinações são possíveis, algumas delas suprindo as mais prementes necessidades da vida humana, enquanto outras produzem surpresa e maravilhamento (Hero, 1971, p.1).

O termo sýrinx significa tubo, assim como aulós. Ele será utilizado também para um dispositivo extremamente útil, em especial para extrair fluidos do corpo, a seringa, descrita por Hero nas Pneumaticas (Fig. 81).

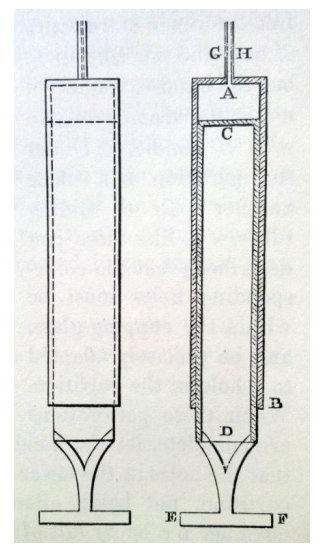

Fig.81: Prancha 57 das Pneumaticas de Hero de Alexandria. Imagem de seringa para fins médicos.

Hero explica que o vácuo está distribuído em pequenas porções no ar, no líquido e em todos os outros corpos. O único material que não compartilha dessa qualidade é o diamante, por ser extremamente denso. O ar é matéria, mas suas partículas não se encaixam completamente, deixando espaços de vácuo entre elas "como na areia da praia" (Hero, 1971, p.2).

Assim, quando qualquer força é aplicada ao ar, ele é comprimido e, de modo contrário à sua natureza, decai nos espaços vazios a partir da pressão exercida em suas partículas; mas quando a força é retirada, o ar retorna a sua posição inicial pela elasticidade de suas partículas, como no caso de raspas de chifre e esponjas, os quais, quando comprimidos e depois liberados retornam à mesma posição e exibem o mesmo tamanho (Hero, 1971, p. 2-3). 
Outras propriedades da matéria são demonstradas, sempre buscando dar provas da existência do vácuo no fenômeno sensível, assim como da produção artificial do vácuo contínuo. Apresentadas as provas, Hero diz que passará aos "teoremas resultantes da combinação desses princípios" (1971, p.10). Ele começa pela apresentação de artefatos como o sifão curvo. Hero era geômetra, mas parece buscar uma simplificação da apresentação matemática nas suas obras de mecânica, sem, no entanto, escapar do estilo geométrico. Como diz Berryman:

A apresentação da tradição mecânica se aproveita dos métodos dos melhores trabalhos científicos de seu tempo. A geometria serviu de exemplo de ciência e seus métodos foram como um padrão a ser imitado; há algumas indicações de que tratados de mecânica tentaram trabalhar dentro desse gênero, estabelecendo primeiros princípios e daí explicando - na forma de "provas individuais" ou "problemas" - a construção de vários artefatos, junto com as linhas de demonstração geométrica. Nas discussões individuais, os textos de Hero seguem o estilo dos problemata matemáticos, na qual uma figura a ser construída é especificada na frase de abertura, às vezes de maneira hipotética: "se queremos tal resultado", ou "se um dispositivo de tal tipo for usado, o seguinte efeito ocorre" (2009, p. 173).

De fato, a construção de alguns mecanismos na Pneumatica inicia-se com uma figura delimitada com letras como nas figuras geométricas. Na Prancha 44 vemos um mecanismo que pode ter inspirado a invenção da hydráulis (Fig. 82). 


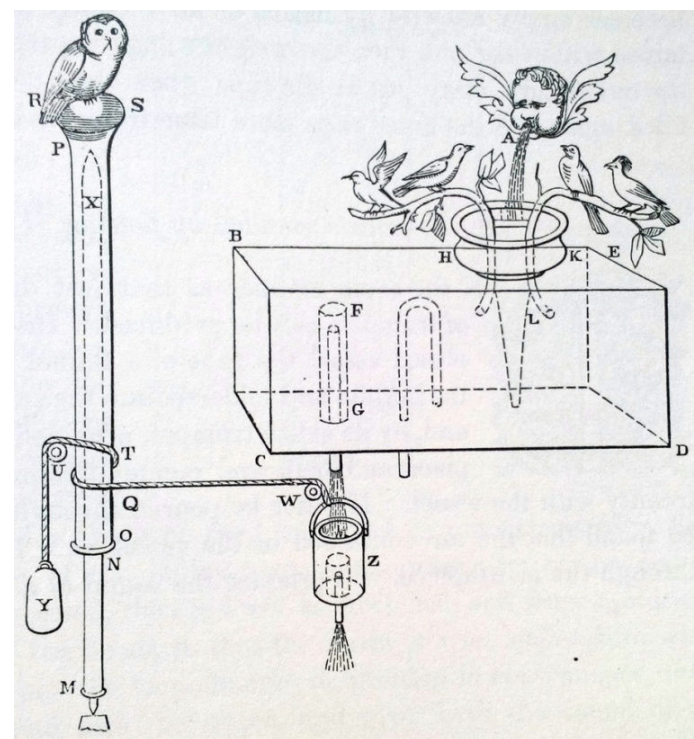

Fig.82: Prancha 44 das Pneumaticas de Hero de Alexandria: "Notas produzidas por diversos pássaros em sucessão por um fluxo de água".

Sons são produzidos em intervalos de tempo como se segue. Um vasilhame é feito com várias partes atravessadas. Nessas câmeras são colocados sifões conduzindo para a câmera de baixo, com os fluxos desencontrados. No compartimento inferior é colocado um tubo que produzirá o som, e o fluxo de água cai no compartimento superior. Descobrir-se-á que, quando a câmera superior for preenchida, a água passará pelo sifão colocado na câmera de baixo, até chegar à última delas, embaixo. A vasilha inteira sendo hermeticamente fechada, o ar nessa câmera é lançado para fora pelo tubo produzindo o som (1971, p. 67).

Berryman comenta a respeito das engenhocas de teatro descritas em outra obra de Hero, Sobre o fazer do teatro:

Na descrição dos artefatos, a abordagem de Hero é mais dirigida aos resultados que aos princípios, embora ele descreva seus artefatos com detalhes criativos e convincentes, e demonstre um virtuosismo técnico que sugere variações elaboradas (2009, p. 139).

Hero pedia aos artesãos que construíam seus dispositivos que fizessem os mecanismos do menor tamanho possível para surpreender o observador (cf. Berryman, 2009, p. 139). Outra descrição de Hero, 
e que talvez tenha sido uma invenção de Ctesibius, é a de uma caixa que funciona com uma cisterna forçando o ar para a boca de um trompetista: "Um trompete, nas mãos de um autômato, soa pela ação do ar comprimido" (Fig. 83). 


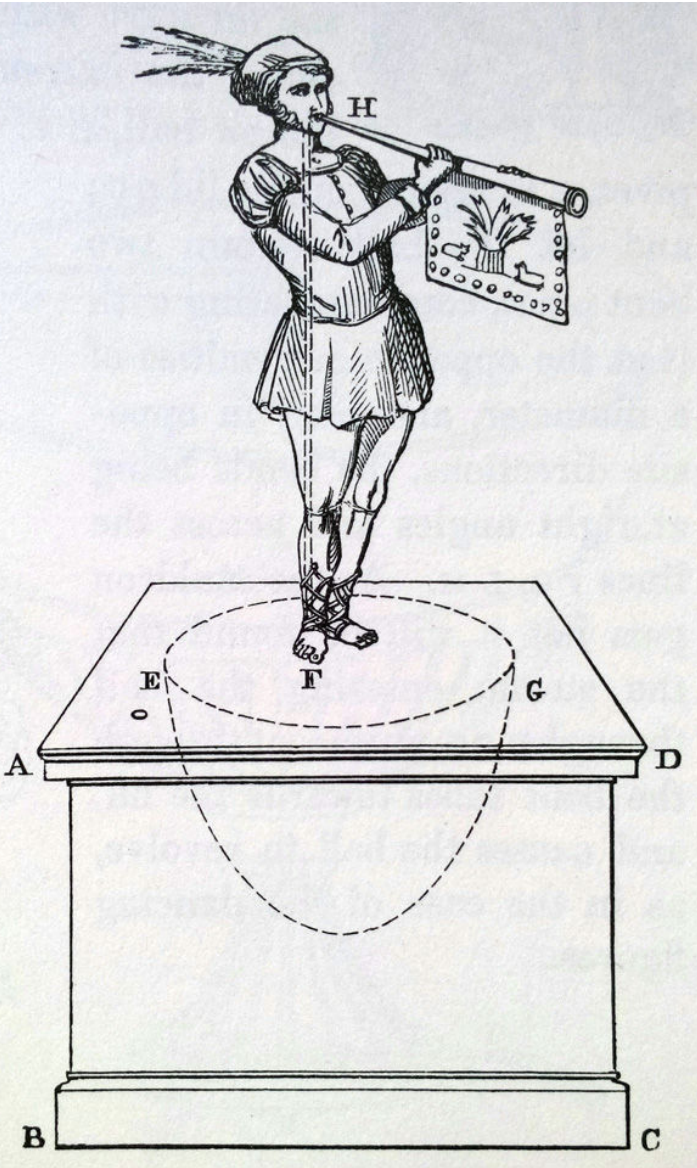

pedestal tem um trompete em sua boca: se houver sopro nela, o trompete soará. Seja a b c d um pedestal de ar comprimido na qual está uma figura, e dentro do pedestal esteja um hemisfério oco (pnigeus), e f g, coberto na parte de cima e com pequenos orifícios na de baixo. A partir do pnigeus, um tubo, h $\mathrm{f}$, se estende para cima entrando na figura e na direção do trompete, que é provido de uma palheta (glótta). Coloque líquido no pedestal por meio de um orifício que deve depois ser fechado por meio de [uma válvula ou tampa] chamada

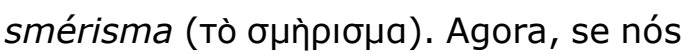
sopramos na campânula do trompete, o ar vai forçar pelos orifícios a água no pnigeus, e vai subir no pedestal; mas quando tiramos o sopro, a água vai entrar no pnigeus novamente e forçará a saída de ar, que passando pela palheta, vai produzir o som de um trompete.

Fig.83: Prancha 49 das Pneumaticas de Hero de Alexandria: "Um trompete nas mãos de um autômato, que soa devido ao ar comprimido". Nota-se que o trompete não tem campana.

Como chama a atenção Perrot, esses sistemas "tinham dois inconvenientes: paravam e tinham uma pressão reduzida de $\operatorname{ar}^{\prime \prime}$ (1971, p. 23). Para que o instrumento soasse de maneira adequada era necessário conseguir pressão suficiente para criar um bom suprimento de ar e manter essa pressão estável. Na hydráulis, a água bombeada vai para uma cisterna e daí ela é forçada a sair por força do ar 
comprimido. Como diz Perrot, a ideia de Ctesibius "não era mover a água por meio de ar comprimido, mas comprimir o ar com o peso da água" (Perrot, 1971, p. 26).

No livro de Hero, há dois modelos de hydráulis, um que é um desenvolvimento do apresentado por Filo e outro movido a vento (Fig. 84). Esse segundo modelo, segundo Perrot, é mais um artefato curioso, uma "fantasia de engenheiro" e certamente não era uma "máquina de uso prático", nem seu inventor deve ter sido Ctesibius (1971, p. 34).

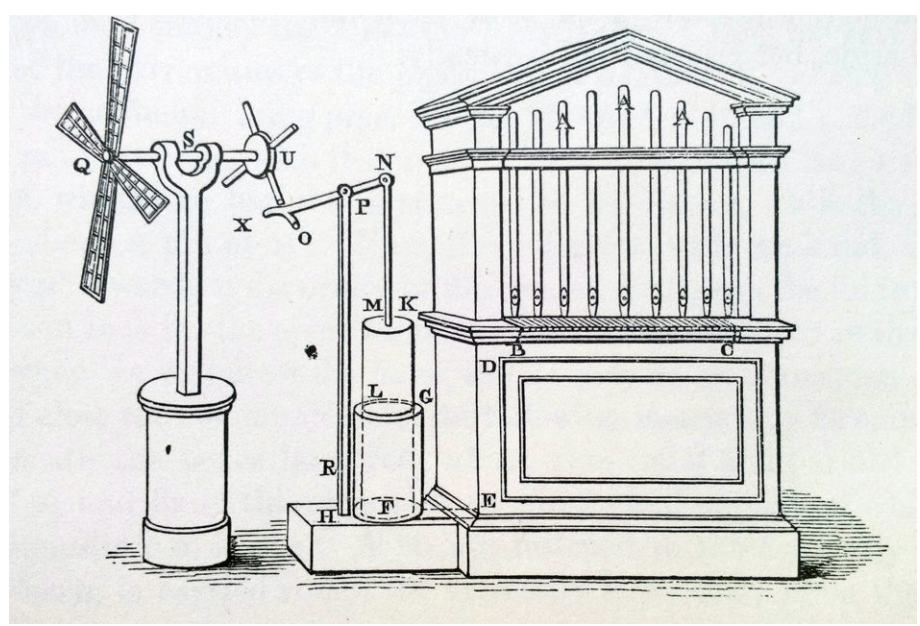

Fig.84: Prancha 77 das Pneumaticas de Hero de Alexandria: "Um órgão de altar alimentado por um moinho de vento".

Concentremo-nos então na hydráulis de fato, descrita por Hero na prancha 76 das Pneumaticas com o título "Um órgão de altar alimentado por trabalho manual". Na Figura 85, vemos o instrumento completo, com o mecanismo em seu interior, tal como presente no facsímile da edição de 1881 . 


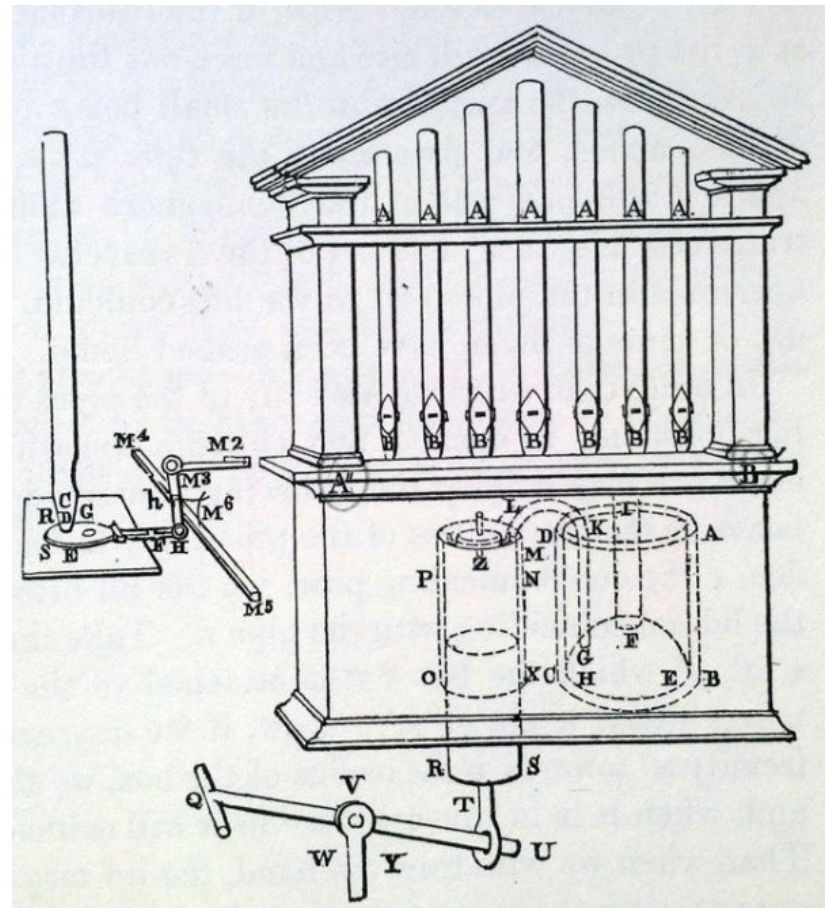

Fig.85: Prancha 76 das Pneumaticas de Hero de Alexandria: "Um órgão de altar alimentado por trabalho manual".

A fim de que, quando quisermos que qualquer um dos tubos (aulói) soe, os orifícios correspondentes possam ser abertos, e fechados novamente quando quisermos que o som cesse, devemos empregar o seguinte dispositivo: imagine que uma das caixas que ficam nas extremidades dos tubos, C, D, seja isolada, D sendo o seu orifício, E o tubo comunicante, $\mathbf{R} \mathbf{S}$ a tampa encaixada nela, e $\mathbf{G}$ o orifício na tampa que não coincide com o tubo E. Pegue três barras articuladas $\mathbf{F H}, \mathbf{H} \mathbf{M}$, e M M2, das quais FH fique presa na tampa SF, enquanto o todo se move em um pino em M3. Agora, se pressionarmos com a mão a extremidade $\mathbf{M} \mathbf{2}$ em direção a $\mathbf{D}$ o orifício da caixa, nós empurramos a tampa para dentro, e quando ela está dentro, a abertura nela irá coincidir com a abertura do tubo.

Para que quando retiremos a mão, a tampa possa ser espontaneamente retirada para fora e feche a comunicação, os seguintes meios devem ser utilizados: embaixo das caixas faça com que uma régua, M4M5, fique igual e paralela ao tubo $\mathbf{A}^{\prime} \mathbf{B}^{\prime}$; fixe nela uma lingueta de chifre, elástica e curva, da qual $\mathbf{M 6}$, ficando na posição contrária a CD é uma delas. Uma corda, presa na extremidade dessa lingueta de chifre, é enrolada na extremidade $\mathbf{H}$, 
de modo que quando a tampa é empurrada para fora, a corda é tensionada; se, portanto, nós pressionamos a extremidade M2 e conduzimos a tampa para dentro, a corda vai forçosamente empurrar a peça de chifre e colocá-la de pé, mas, quando a mão é retirada, o chifre volta para a sua posição original e puxa a tampa do orifício, eliminando a correspondência entre os orifícios.

Estando esse dispositivo aplicado à caixa de cada tubo, quando quisermos que soe um dos tubos, devemos pressionar a chave correspondente com os dedos; e quando quisermos que um dos sons cesse, retirar os dedos, e assim as tampas voltarão para fora e os tubos cessarão de soar.

A água é derramada no altar de modo que o ar em excesso tenha de estar confinado no pnigeus, de modo que os tubos que estão disponíveis para soar possam sempre ter uma reserva. O êmbolo RS, quando levantado, conduz o ar da caixa para o pnigeus, como foi explicado; e quando abaixado, abre a válvula na pequena caixa $\mathbf{z}$. Por esse mecanismo, a caixa é preenchida de ar de fora, que o êmbolo, quando forçado novamente, vai conduzir de novo para dentro do pnigeus. Será melhor que a barra tu também se mova como um pivô em $\mathbf{T}$ por meio de uma simples alça $\mathbf{R}$, que pode ser encaixado embaixo do êmbolo, e através da qual o êmbolo deve passar, para que ele não seja jogado para os lados, mas suba e desça verticalmente (Hero, 1971, p. 106-7).

Outras ilustrações foram feitas com o mecanismo buscando mostrar o seu funcionamento, como no manuscrito de Veneza, de 1250, segundo Perrot, os diagramas em amarelo, verde e vermelho, que acompanham o manuscrito, devem ter existido no original, porque as letras correspondem (Fig. 86). 


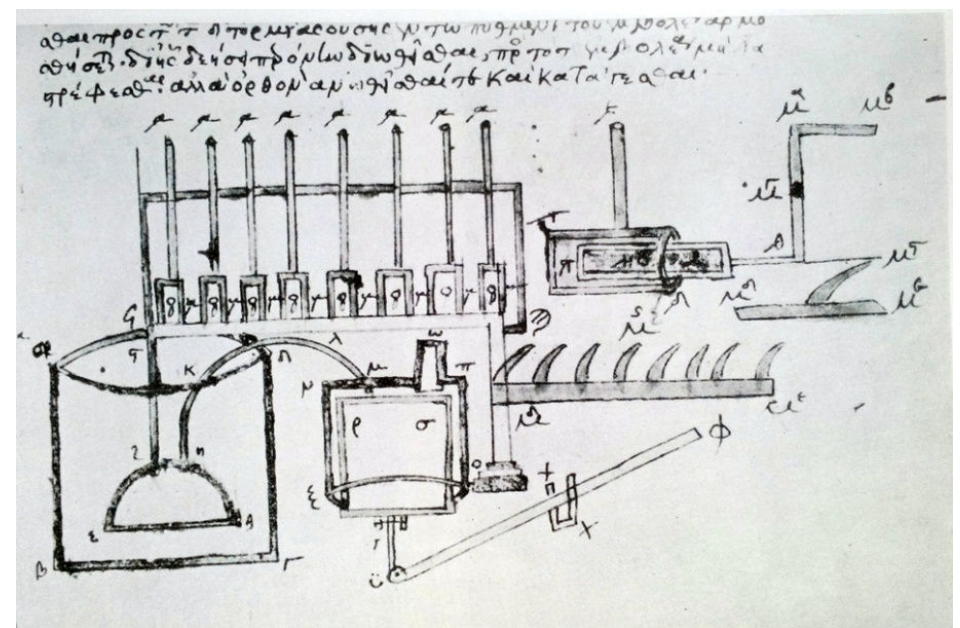

Fig. 86: Ilustração do manuscrito das Pneumaticas de Hero de Alexandria, original em amarelo, verde e vermelho.

Um órgão deve ter uma maneira de gerar o suprimento de ar e estabilizá-lo, um conjunto de tubos para produzir tons distintos e uma forma do músico direcionar o ar para os tubos desejados. Tudo isso é encontrado na hydráulis.

A parte do mecanismo que cria o suprimento de ar e o envia para a câmara era composta da alavanca que pressionava o êmbolo em um cilindro extremamente polido, conforme já havia sido mencionado por Filo de Bizâncio. Na parte superior desse cilindro havia uma válvula pequena que abria e fechava na medida da pressão do ar feita pelo êmbolo. $\mathrm{O}$ ar assim passava pelo sifão para dentro do pnigeus colocado no interior da cisterna. O pigneus tinha orifícios na parte inferior, e quando o ar entrava nele, a água saía e subia fazendo com que seu peso impulsionasse o ar comprimido para o outro sifão, que o levava até a câmara de ar em que estavam os tubos que iriam gerar o som. É um complexo lógico, com antecedentes e comsequentes caminhando para o objetivo final: o tom musical, mas nas mãos de uma musicista como foi Taïs, ele se transformou num verdadeiro condutor de mudanças fundamentais para a construção da linguagem da música ocidental.

Como lembra Perrot, há uma falha na descrição de Hero, mas que deve ter sido ocasionada por um erro de algum copista, pois 
segundo o autor, Hero era muito detalhista em suas descrições. O erro é a ausência da válvula de retorno no ar que deveria ficar na base do sifão, reponsável por conduzir o ar comprimido para a câmara de ar, sem essa válvula, o ar voltaria. Na Figura 87, a ilustração de Perrot mostra o mecanismo do ar comprimido da hydráulis de Hero.

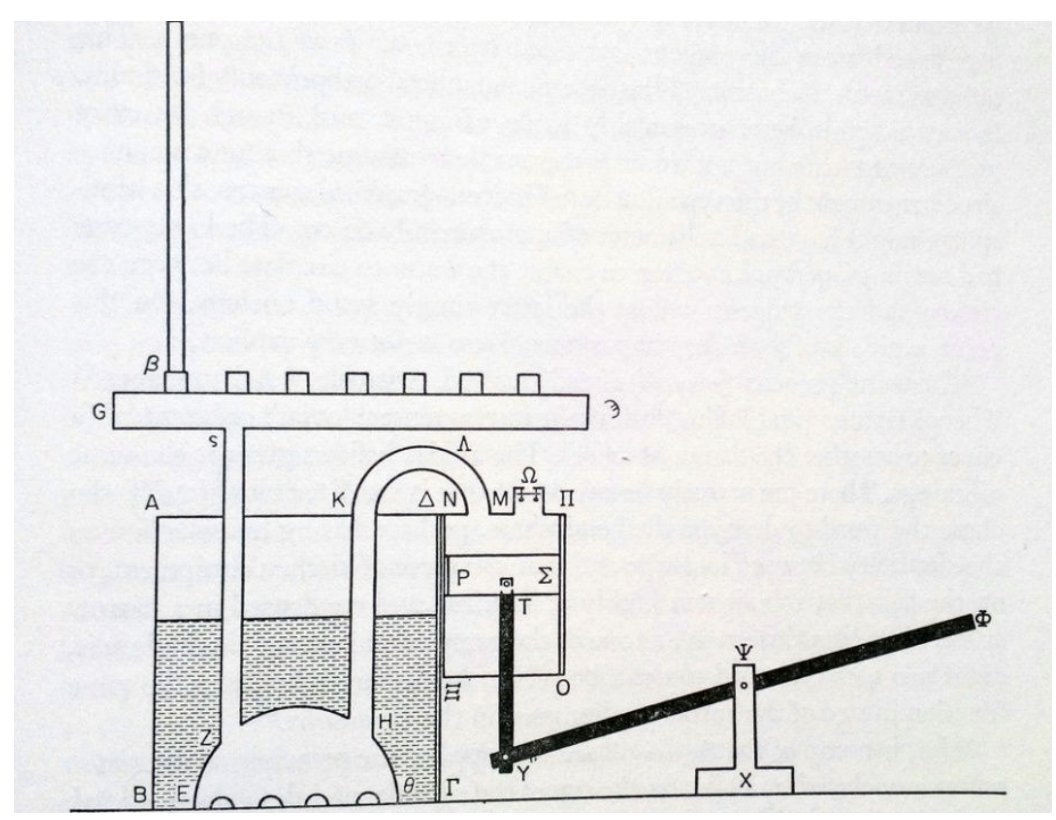

Fig. 87: Mecanismo de ar comprimido da hydráulis. Modelo descrito por Hero de Alexandria.

A cisterna de água, bomískos (ó $\beta \omega \mu$ í́коৎ), era feita de metal, cobre ou bronze, assim como o pnigeus. O bomískos sustentava a câmara de ar e, acima dela, os tubos do instrumento. O cilindro onde ficava o êmbolo que gerava a pressão de ar era controlado por uma manivela, ambos no lado externo do instrumento. A pressão do ar era estabilizada pela água, o que fazia com que o ar também apresentasse essa tendência estável. No entanto, a água tornava o instrumento muito pesado e costumava enferrujar suas partes de metal, além de acelerar o apodrecimento da madeira. Mas era exatamente por causa da água que "a hydráulis possuía um som vigoroso, pois a pressão de ar é mais forte e mais constante que a do fole" (Williams, 1980, p. 25). Além disso, as palhetas nos tubos também aumentavam o volume de 
som. Provavelmente, Ctesibius retomou na hydráulis, o princípio do autômato com o trompete que tinha uma palheta (glóssis) e só mais tarde foram construídos instrumentos com o tubo livre, sem palhetas. Com a introdução desses registros de flauta, o instrumento certamente ganhou novos recursos em termos de timbre e dinâmica.

A base da hydráulis era muitas vezes representada no formato hexagonal. Não é possível ver o teclado nas representações, mas temos a descrição detalhada de Hero do mecanismo dos tubos e do seu acionador, o teclado manual.

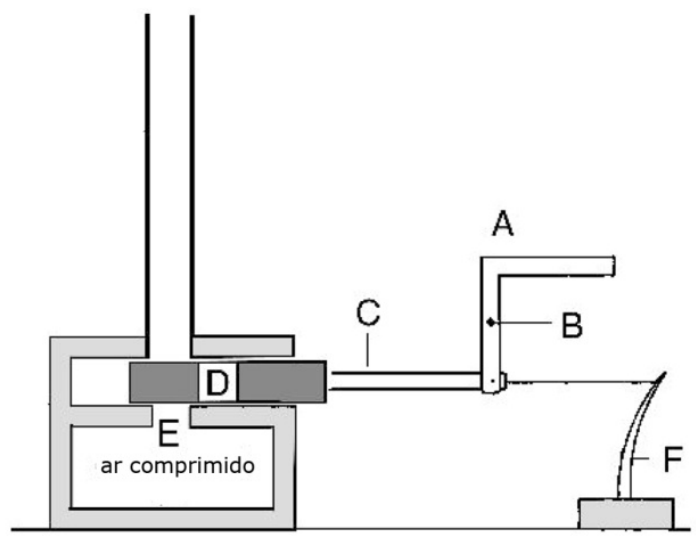

Fig.88: Mecanismo da tecla da hydráulis.

Quando o teclado era pressionado, a tecla fazia um movimento pivotante puxando a parte que interrompia a saída do ar, fazendo soar o respectivo tubo e retornando pela ação dessa espécie de mola de chifre e cordas. Como diz McKinney, o invento

não possuía a origem evolucionária básica da maioria dos antigos instrumentos musicais. Ele era uma máquina complexa envolvendo mais elementos novos que antigos e, portanto, era precisamente o tipo de invenção que se poderia esperar da Alexandria do século III a.C., de Euclides, Eratóstenes, Arquimedes e Ctesibius. Assim, ela foi vista primeiro como uma maravilha mecânica mais que um instrumento musical $(2013$, p. 2). 


\subsection{A hydráulis no mundo romano}

De fato, a hydráulis exerceu um fascínio por sua combinação de tecnologia e arte e, segundo Campbell, "por seu poder potencialmente enorme e amplas capacidades em geral sob o controle de apenas um executante" (2009, p. 394). O autor observa ainda que o instrumento tinha todos os elementos básicos do órgão moderno: "uma forma de gerar e regular o suprimento de ar, um conjunto de tubos para produzir sons e uma série de válvulas operadas pelo executante de modo a direcionar o ar para os tubos desejados" (2009, p. 394).

$\mathrm{O}$ arquiteto romano Marcus Vitrúvius Pollio, tal como Hero, viveu no século I d.C., no entanto, a descrição da hydráulis em sua obra Sobre a arquitetura é a de um instrumento bem mais sofisticado que o de Hero. Hero pode ter feito sua descrição a partir do livro de Ctesibius, Comentários, do qual não temos vestígios. O modelo de Hero tem apenas uma série de tubos e, ademais, ele não dá nenhuma descrição da parte musical do instrumento, como tessitura e afinação.

Vitrúvio tem conhecimento musical e de acústica, inclusive um dos capítulos de sua obra é dedicada à teoria musical grega, tanto pitagórica quanto aristoxeniana. No Livro 5, Vitrúvio dá uma clara demonstração da aplicação do modelo musical pitagórico à acústica dos teatros, explicando detalhadamente a colocação de vasos ressonantes em locais específicos do espaço. Além disso, o autor romano demonstra que também a harmônica aristoxeniana, apesar do esforço de Aristóxeno em delimitar seu objeto, foi utilizada em outras áreas do conhecimento, como a arquitetura. Vitrúvio recomenda um diagrama de fácil aplicação, seguindo o modelo do tarentino:

Se alguém, realmente, desejar realizar estas coisas facilmente e com perfeição, veja no fim do livro um diagrama desenhado segundo as regras musicais, que Aristóxeno, com grande brilho e indústria, deixou organizado com as modulações classificadas por gêneros, a 
partir do qual, aquele que seguir essas regras poderá realizar mais facilmente os acabamentos dos teatros, segundo as características da voz e para deleite dos ouvintes (2006, p. 187).

A hydráulis de Vitrúvio mostra que ele de fato esteve em contato com o instrumento. Ele mesmo, ao final da descrição, aconselha a quem não o compreendeu bem, buscar ver o instrumento em funcionamento. Esse instrumento do século I d.C. já tinha passado por modificações a fim de corrigir problemas de vazamentos de ar, ferrugem, emperramento das gavetas do teclado ou falta de homogeneidade de tensão nas cordas que puxavam as teclas de volta, algo que precisava acontecer de maneira "espontânea", como diz Hero. Além disso, de acordo com Perrot,

A adição subsequente de vários "registros" complicou a sua mecânica, mas o problema foi resolvido de maneira satisfatória, embora não se saiba por quem - no final do século I d.C. (1971, p. 33).

A hydráulis de Vitrúvio tinha duas bombas cilíndricas nas laterais, em vez de apenas uma, e suas válvulas eram mais eficientes. Ele

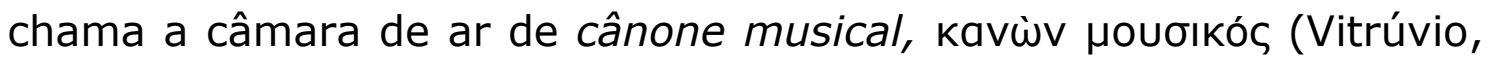
10. 83). Ela era capaz de alimentar oito conjuntos de tubos. $O$ arquiteto é bastante cuidadoso na descrição dos materiais com que as partes são feitas: a cisterna onde ficava a água era feita de bronze, assim como os dois cilindros laterais, "cuidadosamente trabalhados no torno para adequar exatamente o diâmetro dos êmbolos" (apud Perrot, 1971, p. 36).

Os cilindros funcionavam alternadamente e os êmbolos eram revestidos de couro, permitindo que fossem refeitos quando estivessem desgastados. No caso específico desse instrumento vitruviano, as duas válvulas acima dos êmbolos tinham a forma de golfinhos de bronze e assim, quando o órgão estava sendo tocado, as 
válvulas abriam e fechavam, e os golfinhos pareciam mergulhar e subir.

A câmara de ar permitia que o músico escolhesse o conjunto de tubos que quisesse fazer soar, um desenvolvimento possivelmente feito por um aulopoiós que permaneceu anônimo. Essa inovação permitiu aumentar os contrastes de timbres com registro de palhetas e de flautas, e de altura, com a base, a quinta e a oitava, avanço técnico que será o impulso de futuros desenvolvimentos musicais. Perrot explica o funcionamento da câmara de ar.

$\mathrm{O}$ ar dos pnigeus não entra em contato com os pequenos reguladores operados pelas teclas, como acontecia com o órgão de Hero. Em vez disso, compartimentos separados correm ao longo da câmara de ar, quatro, seis ou oito [compartimentos], dependendo do tamanho do instrumento. Cada um deles se comunica com uma pequena câmara por meio de uma válvula que tem uma manivela de ferro, de modo que $o$ ar entra naquelas que estão abertas. Quando o organista quer trazer um conjunto específico de tubos ele abre a válvula correspondente (1971, p. 41).

Ao longo do cânone musical do órgão vitruviano existiam canais: quatro, se o instrumento fosse tetracordal, seis, se fosse hexacordal e oito, se fosse octocordal. Cada canal era encaixado em uma válvula reguladora que tinha uma manivela de ferro; entre a prancha superior

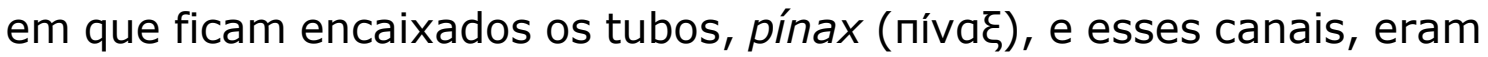

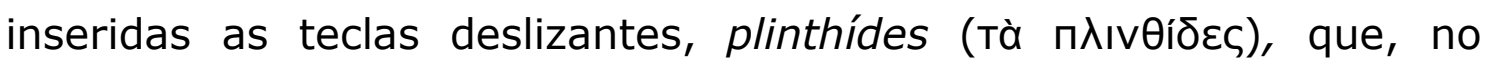
instrumento de Hero, tinham apenas um orifício, e agora têm quatro, seis ou oito. Em vez das espátulas de chifre que fazem-nas retornar, molas de ferro fazem essa função, embora não haja descrição detalhada do teclado. 


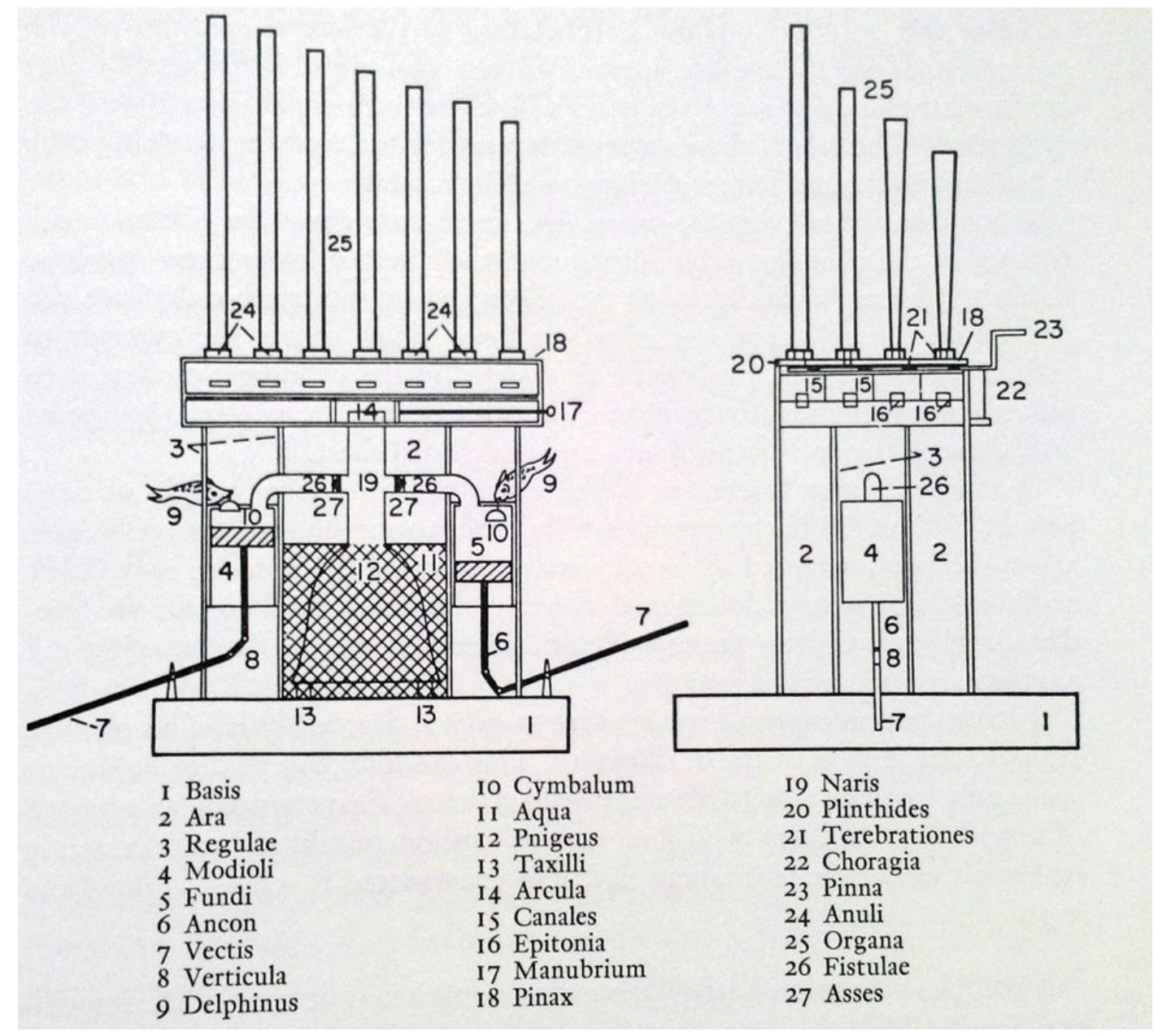

Fig.89: Modelo da hydráulis de Vitrúvio.

Por seu grande volume de som, a hydráulis era utilizada em eventos como circos e teatros, e foi introduzida também nas competições. Uma inscrição délfica, de cerca de 90 a.C., fala de um vitorioso Antipatros que teria se apresentado ao instrumento por dois dias, fazendo muito sucesso.

A primeira referência à hydráulis na literatura latina é de Virgílio. Em seu poema Aetna, ele compara o som do instrumento ao do vulcão, que também movimentaria enormes massas de água, fazendo comprimir o ar.

Nos grandes teatros, um instrumento na forma de domo cria a música por meio da água. Melodioso, com sua variedade de notas, ele canta regulado pela arte do performer, pois um fluxo de ar é impulsionado 
pela água que pressiona por baixo, como com um remo (Aetna, 295-7 apud Perrot, p. 46, n. 11).

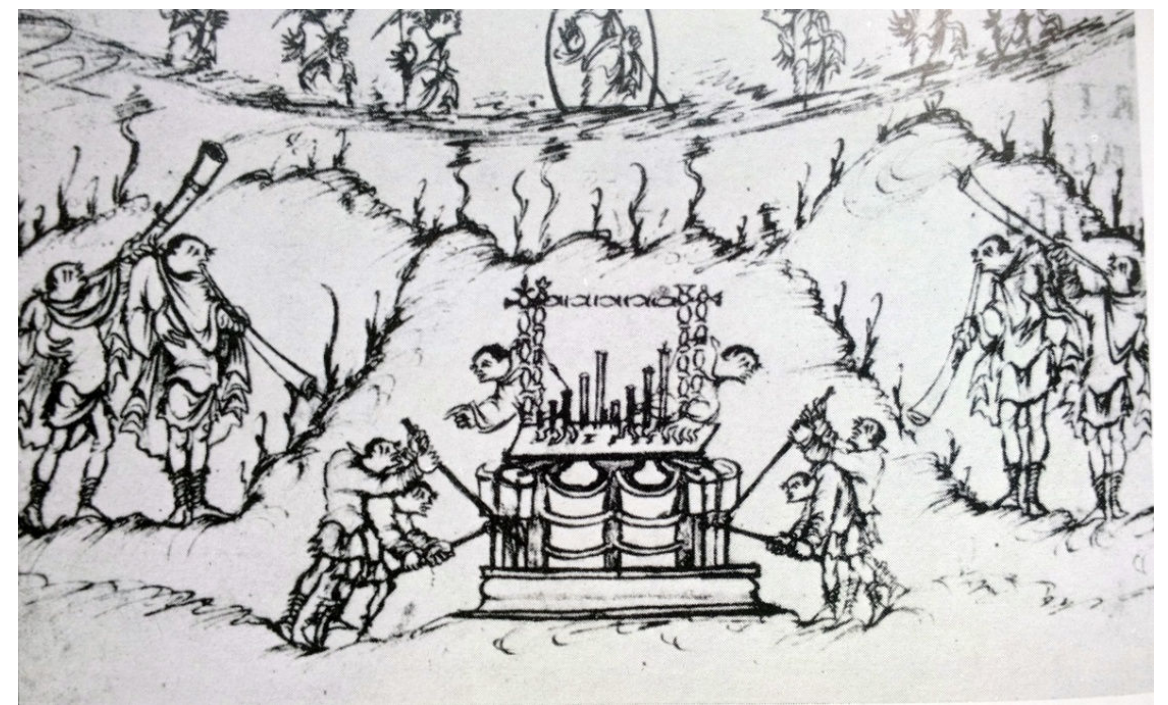

Fig.90: Detalhe de ilustração do Psaltério de Utrecht (sécs. XI a XIII) para o salmo 149 Laudate nomen eius in choro, in tympano et psalterio. Nota-se que dois músicos tocam o instrumento, mas aparentemente não há teclado, pois eles estão fechando os orifícios do órgão com os dedos.

Segundo McKinney "se a hydráulis foi empregada na prática de música polifônica é incerto; mas aparentemente ela tinha capacidade para tocar em até duas vozes" (McKinney, 2013, p. 5). Ela costumava ser representada ao lado de instrumentos como a tuba, análoga à sálpinx grega, e a bucina, um "grande trompete circular, com a campana alargada e cuja orbe era munida de uma ripa de madeira" (Bélis, 1988b, p. 241). Os três aparecem na iconografia em cenas de lutas de gladiadores; além de fazerem a parte musical, talvez fizessem uma espécie de sonoplastia, como mostram as ilustrações abaixo, em que os olhares atentos dos músicos parecem aguardar algum sinal dos lutadores (Fig. 91). 


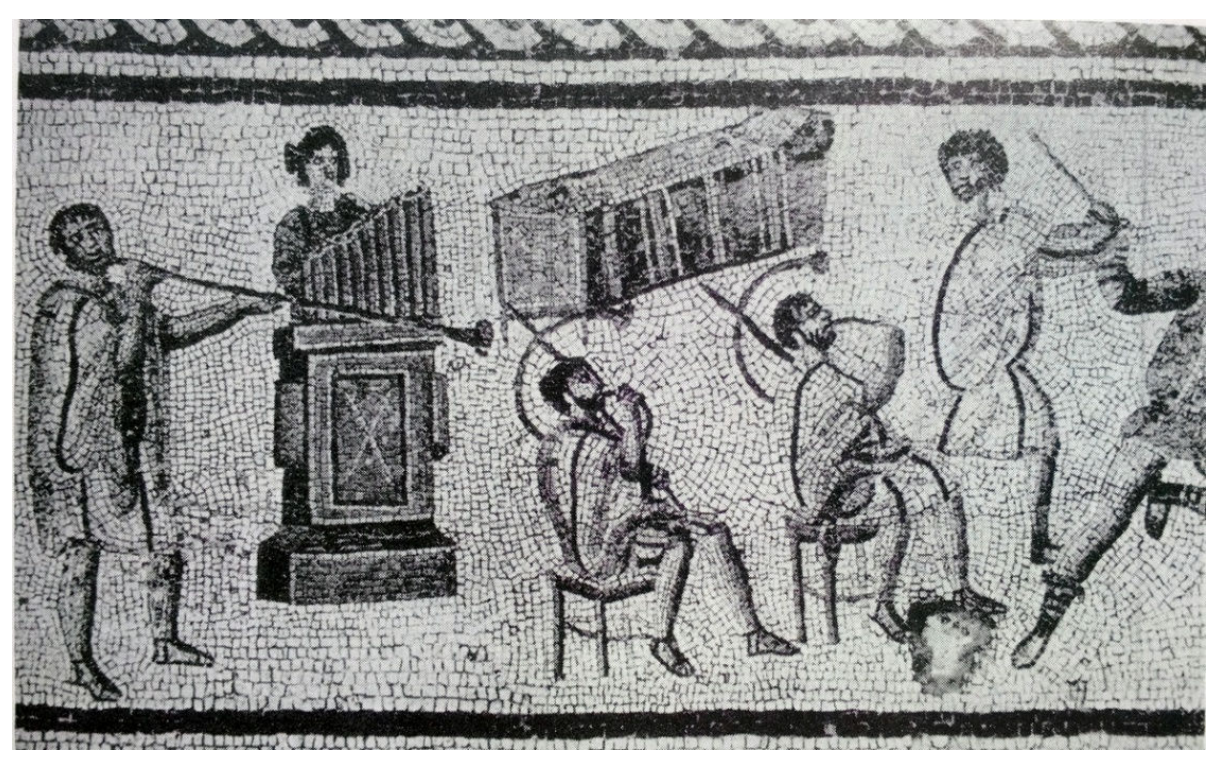

Fig.91: Mosaico de Zliten encontrado em vila romana próxima ao oásis de Zliten, na antiga colônia italiana Tripolitania, Líbia atual. Músicos com hydráulis, bucina e cornu. Nota-se os olhares voltados para a luta.

Em um mosaico romano do tempo do imperador Adriano, século II d.C., há uma cena que parece representar uma luta de gladiadores. O modelo é o descrito por Vitrúvio com duas bombas laterais. Como não há pessoas bombeando o ar, Perrot levantou a hipótese de esse instrumento ser manipulado por pedais (cf. Perrot, 1971, p. 73-5) (Fig. 92). 


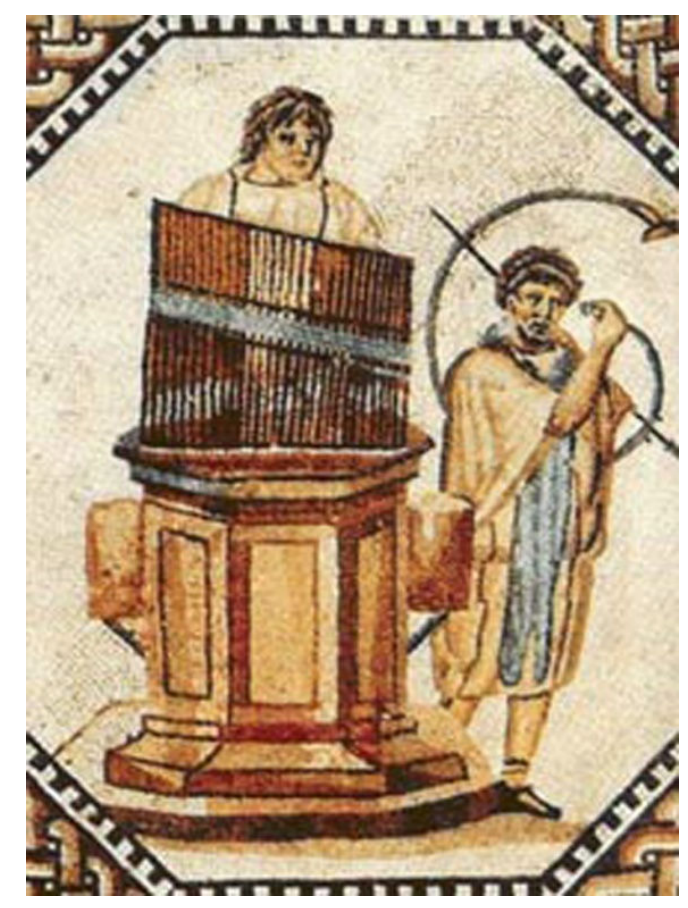

Fig. 92: Mosaico de Nennig. Hydráulis e cornu tal como retratadas no famoso mosaico da vila romana de Nennig, Alemanha, século II d.C.

A obra $O$ banquete dos sofistas, de Ateneu, é uma das grandes fontes de conhecimento de instrumentos musicais e apareceu várias vezes ao longo deste estudo. Ela foi escrita entre os séculos II e III d.C., e nela há uma descrição da sonoridade da hydráulis.

Enquanto a conversa ia se desenrolando, o som de uma hydráulis foi ouvido da casa do vizinho, muito doce e prazeroso, de modo que chamou a atenção de todos nós, fascinados pela melodia. Então Ulpiano olhou para o músico Alcides: "Tu, que és o mais musical dos homens, ouviste essa música maravilhosa (kales symphonias) que arrebatou a todos nós? Como ela é diferente do grande monaulós tão comum entre vós, alexandrinos, que faz os ouvintes sentirem dor ao invés de prazer!". Então Alcides respondeu "E esse instrumento, a hydráulis, quer você classifique como de sopros ou de cordas, foi inventado por um cidadão vosso, cabeleireiro de profissão, de nome Ctesibius (...) Aristóxeno não o conheceu" (apud Perrot, 1971, p. 6).

Ctesibius não era cabeleireiro, e sim seu pai, mas o que importa é a observação de que Aristóxeno não conheceu a hydráulis. Na medida em que Aristóxeno era a grande autoridade musical, o seu 
desconhecimento dessa maravilha mecânica, que irá modificar gradualmente a música ocidental, é uma marca significativa. $\mathrm{Na}$ hydráulis, o som, pela primeira vez não é produzido de maneira visível e imediata, pois o teclado, genial invenção do período alexandrino, deve acionar um dispositivo que desencadeia um processo até que haja a emissão sonora. O teclado, como novo artefato, logo tornar-se-á o novo modelo de representação da música. Esse dispositivo que nasceu na confluência de civilizações gregas e do Oriente Médio será um dos mais característicos da música ocidental.
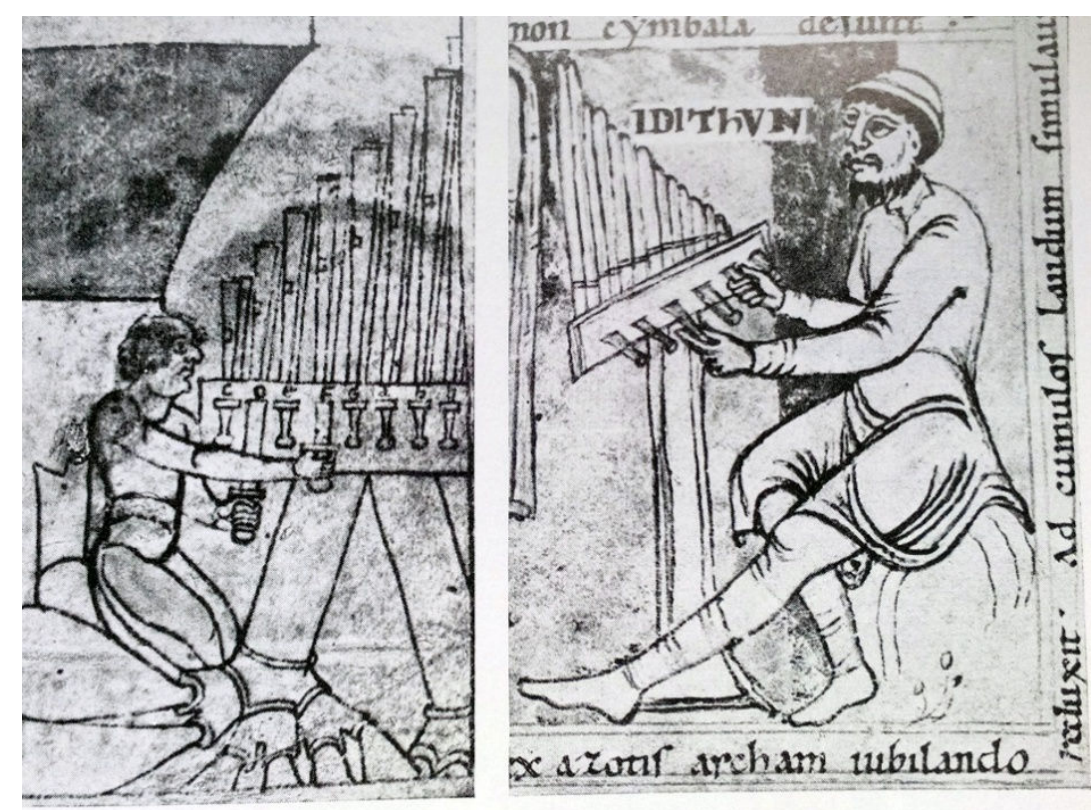

Fig. 93: Duas imagens de teclados. À esquerda, da Bíblia de Harding, século XI para XII; à direita, do Psaltério de Pommersfelden, século XI.

No século IV d.C., Pappus de Alexandria, em sua obra Synagóge, elenca as atividades compreendidas sob a denominação de mecânica, que segundo ele possui uma parte teórica e outra prática. A primeira consiste nos conhecimentos de geometria, aritmética, astronomia e física. A segunda engloba o trabalho em metal, a construção, a carpintaria e pintura, e outras atividades relacionadas. Mais adiante, ele diz que se alguém não puder se ocupar das duas partes é melhor se ocupar das que são mais necessárias à vida humana e dá uma lista 
de cinco itens das "artes mecânicas do ponto de vista das necessidades da vida": a que trabalha com pesos levantados por roldanas, a que faz os instrumentos para a guerra, a que cria máquinas de todo tipo, como as de carregar água, a que produz máquinas que maravilham e a que constrói esferas como modelo dos céus (cf. Lloyd, 1973, p. 92). No século seguinte, Proclo de Atenas faz uma lista das mecânicas e inclui nela "a manufatura de dispositivos maravilhosos, baseados em fluxo de ar, pesos e cordas" (Berryman, 2009, p.59).

É possível que essas classificações tenham sido o motivo pelo qual a hydráulis, apesar de sua enorme penetração no mundo romano, tenha passado desapercebido por autores como Ptolomeu, que não o considerou em seus estudos musicais, sem perceber o alcance que teria essa modificação tecnológica no próprio fazer musical. 


\section{Capítulo 6 - 0 ATELIÊ MUSICAL DE CLAUDIO PTOLOMEU}

\subsection{A harmônica ptolomaica}

Claudio Ptolomeu é conhecido como matemático e astrônomo, mais um cientista na concepção moderna que um filósofo, embora os autores antigos, em especial a partir do período helenístico, incluam a "física" entre os ramos da filosofia. As áreas às quais se dedicou Ptolomeu estão entre "as mais físicas das matemáticas" (Aristóteles, 194a), aquelas que trabalham diretamente com a natureza, no sentido de Aristóteles, que no Livro 2 da Física, faz a distinção entre as disciplinas físicas e matemáticas em que os objetos matemáticos podem ser estudados de maneira abstrata, mas não os corpos naturais ou físicos, que devem ser investigados pela física. Para Aristóteles, existem ciências que trabalham com objetos naturais, de maneira matemática:

Isso aparece nas mais físicas dentre as matemáticas: a óptica, a harmônica e a astronomia, pois, de certo modo, elas se comportam de maneira inversa à geometria; pois a geometria estuda a linha física, mas ela não é física - ao contrário, a óptica estuda a linha matemática, não enquanto matemática, mas enquanto física (194a).

No conjunto da obra ptolomaica, a Harmônica é considerada uma obra menor. Contudo, ela merece atenção especial, não por expor as sutilezas dessa ciência ou filosofia, mas pelo fato do autor explicitar ali alguns de seus procedimentos científicos e metodologias. Além disso, Ptolomeu escreveu livros especificamente sobre questões epistemológicas, que são explicitadas no método que emprega na Harmônica.

Ptolomeu é reconhecido principalmente por suas obras de astronomia, em que apresentava uma teoria coerente e com alto grau de predição. Por exemplo, no caso das predições da Lua o modelo 
ptolomaico é considerado "suficientemente exato, mesmo se, tratado como explicação física, ele entre em contradição flagrante com os fatos" (Lloyd, 1990, p. 149).

O historiador francês Pierre Duhem, no início do século $X X$, propôs uma interpretação, que se tornou bastante influente, na qual dividia as posturas das ciências antigas entre "instrumentalista" e "realista" (cf. Duhem, apud Lloyd, 1991, p. 276). A primeira posição estaria presente na noção grega de "salvar as hipóteses", 36 ou "salvar

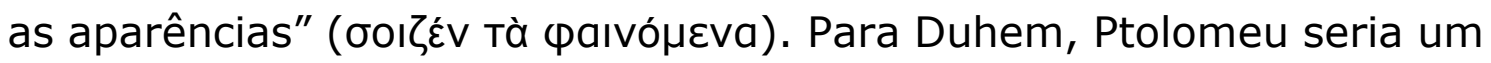
caso típico de cientista instrumentalista, na medida em que, em suas obras de astronomia, ele teria revisado ou rejeitado o movimento dos astros de modo a acomodar leis pré-estabelecidas por cálculos matemáticos. Esse ponto de vista de Duhem foi criticado em 1978 por Geoffrey Lloyd no artigo "Saving the appearences" (cf. Lloyd, 1991, p. 254-277). Ali, o autor aponta, entre suas objeções, que havia um pluralismo de concepções na ciência antiga e que os papéis do astrônomo e do físico não eram totalmente independentes, como Duhem havia proposto. Para Lloyd,

se considerarmos algumas das maiores figuras (...) que mencionamos - Eratóstenes e Posidônio em geofísica, Hiparco e Ptolomeu em astronomia, Aristóxeno, Ptolomeu e Porfírio em harmônica, e Ptolomeu, novamente, na ótica - não há nada que sugira que eles tenham levantado dúvidas céticas radicais acerca do valor da percepção sensível para suas investigações (Lloyd, 1987, p. 272-273).

A posição de Duhem é igualmente relativizada por Sedeño na introdução que elaborou à sua tradução da obra de Ptolomeu As hipóteses dos planetas, escrita provavelmente com a intenção de trabalhar questões que não haviam sido contempladas de maneira

36 O significado grego para "hipótese" é diferente do atual, que é o de um enunciado que se refere a um ponto de partida ainda não comprovado. Para os antigos gregos, "hipótese" é um modelo ou uma explicação. 
satisfatória em trabalhos anteriores. Apesar de, mesmo na Syntaxis, Ptolomeu ter demonstrado estar "consciente da importância da física e da necessidade de efetuar uma espécie de síntese de modo a evitar que as questões físicas ficassem à margem" (Sedeño, 1987, p. 35), segundo a autora, em As hipóteses dos planetas, ele busca alcançar uma explicação física do universo, em especial quando descreve os círculos que dirigem os movimentos celestes. Nesse momento, Ptolomeu teria rejeitado a teoria aristotélica em favor de noções vitalistas: "Devemos supor que entre os corpos celestes cada planeta possui por si mesmo uma força vital, que ele se move por si mesmo e que ele comunica seu movimento aos corpos que the são unidos por natureza" (Ptolomeu, 1987, 2, cap. 7; apud Lloyd, 1990, p. 150).

Lloyd chama a atenção também para a Óptica de Ptolomeu, na qual os princípios descritos seriam conhecidos muito antes dele, mas que sua contribuição teria sido a de os haver "confirmado experimentalmente", ainda que ajustando-os à lei geral matemática. Como diz Lloyd, com a precariedade dos instrumentos de que dispunham os antigos, eles estavam certos em "confiar mais em seus métodos matemáticos que em suas observações" (1990, p. 157), mas isso não deixa margem para afirmar que Ptolomeu desqualificava completamente a observação.

Pouco se sabe da vida de Ptolomeu. Estima-se o período em que viveu a partir das observações astronômicas que ele fez no paralelo de Alexandria entre 127 d.C. e 141 d.C. A Alexandria de Ptolomeu já não era a mesma do tempo em que lá viveu a plêiade de cientistas composta por Euclides (360 a.C.-295 a.C), Ctesibius (cerca de 285 a.C.- 222 a.C) e tantos outros. Desde o século I a.C., a cidade vivia sob o regime dos imperadores romanos, que transformaram o Egito no celeiro do Império e a cidade tornara-se um centro comercial cosmopolita, entre Roma e África. Mas tanto a biblioteca quanto o museu ainda estavam em funcionamento. A obra de Ptolomeu evidencia o conjunto de conhecimentos e aptidões desenvolvidos até 
então e a facilidade de acesso a informações que propiciava o ambiente da cidade. Em todas as áreas a que ele se dedicou, a quantidade de informação detalhada que ele consegue reunir é enorme. Nesse momento, as mensurações são privilegiadas pois legitimam os avanços científicos, especialmente na geofísica, na óptica, na astronomia e na harmônica, seus principais campos de trabalho.

Alguns historiadores da filosofia classificam o período em que viveu Ptolomeu como eclético. Segundo eles, o ecletismo teria surgido após o helenismo, quando emergiram movimentos como epicurismo, estoicismo e ceticismo, e antes do surgimento do neoplatonismo no século III d.C. O termo eclético referir-se-ia tanto à filosofia dos romanos Cícero e Sêneca quanto à ciência de Ptolomeu e Galeno.

A denominação eclética ganhou uma conotação negativa, em especial na obra do filósofo alemão Edouard Zeller (1814-1908), que caracterizou a época como a de um vigor intelectual menor, concepção que foi muito divulgada (cf. Donini, 1996, p. 22-6). O ecletismo teria uma tendência em apaziguar as controvérsias que existiram na Antiguidade e, sobretudo, de resistir à exploração que os céticos haviam feito dos dissensos.

Lloyd, que, chamou a exacerbação constante de rivalidade entre as teorias de "tradição grega da contestabilidade de uma tradição" (1987, p. 107), diz que, já a partir do século IV d.C. essa tradição começou a esmaecer, e o equilíbrio de forças da tensão entre tradição e inovação voltou-se gradativamente para a tradição, cedendo lugar para a postura de referência à autoridade de grandes figuras do passado, como Pitágoras, Hipócrates, Platão e Aristóteles e, mais tarde, Galeno e Ptolomeu. Surgem os comentadores, que não têm como objetivo criticar os textos, mas apontar de que maneira eles contêm a verdade. Alguns desses autores "buscam mostrar como Platão e Aristóteles estavam num acordo substancial, assim como no século II d.C. Galeno também frequentemente busca reconciliar Platão e Hipócrates" (1987, p. 105). Essa deferência tornar-se-á uma tópica 
da retórica que passa a ter como ponto de partida a auctoritas dos antigos. Lloyd chama a atenção, no entanto, para o fato de que não devemos nos confundir com essa tópica retórica, pois Galeno e Ptolomeu, por exemplo, fizeram contribuições originais aos seus campos, "tanto como teóricos quanto como observadores" (1987, p. 106). Autores como Dillon e Long restabeleceram alguns aspectos filosóficos importantes do ecletismo, em especial de cientistas práticos como Galeno e Ptolomeu:

\begin{abstract}
Enquanto era adequado aos céticos representar filósofos doutrinários como proponentes de opiniões discrepantes radicais, cientistas práticos tinham interesse em descartar diferenças sutis entre conceitos e teorias de cujas bases gerais eles poderiam se apropriar como sustentação de suas metodologias (Dillon \& Long, 1996, p.10).
\end{abstract}

Para os autores, Galeno e Ptolomeu teriam praticado o "reverso da estratégia dos céticos de opor as teorias umas às outras refutando assim todas". Esses cientistas teriam considerado a relação de reciprocidade que há entre observações controladas e postulados teóricos a fim de utilizar "de uma maneira inovadora os conceitos tradicionais no interesse de um novo tipo de filosofia da ciência" (Dillon \& Long, 1996, p.10).

Ptolomeu marcou sua posição no campo da epistemologia na

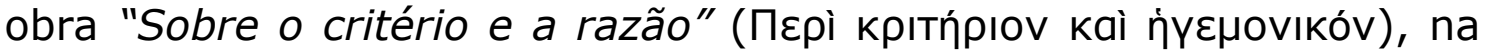
qual faz um apanhado das faculdades cognitivas e suas funções e também das formas como interagem corpo e alma na constituição humana. Essa epistemologia será colocada em prática na Harmônica que talvez tenha sido sua obra mais significativa. Como chama a atenção Long, na Harmônica "a combinação de indução e dedução remete à prática da 'disposição científica' de coleta e divisão presente em 'Sobre o critério"' (1996, p. 204). 
Ptolomeu busca, como cientista, estabelecer critérios confiáveis para conhecer seus objetos. Ele não nomeia filósofos ou oponentes, apenas seleciona elementos da tradição filosófica e a partir delas, assume posições próprias. Isso fica claro na sua abordagem da controvérsia entre pitagóricos e aristoxenianos.

Como vimos anteriormente, a especulação sobre os tons musicais no século VI a.C. teve como resultado uma lei da acústica e da física matemática, a proporcionalidade inversa entre a altura do tom e o comprimento de uma corda vibrante, formulada em termos de razões aritméticas. Esse marco inaugural dos pitagóricos inseria-se na concepção pré-socrática da existência de uma ordem intrínseca da natureza, inalcançável pelos sentidos. Mas a ordenação musical possuía uma especificidade, na medida em que podia ser facilmente reproduzida e observada em um instrumento, no caso, uma corda esticada. Uma relação entre realidade e representação é estabelecida por meio da mensuração de uma corda.

No desenrolar da presença do pitagorismo na teoria musical antiga, a abordagem racional expressa pela aritmética se impôs sobre o empirismo da utilização do cânone, instrumento criado para a verificação das consonâncias. As razões aritmético-musicais pitagóricas fortaleceram a noção de harmonia universal e tornaram-se um grande modelo para a ciência, perpetuando-se ao menos até o início do século XVII.

Ptolomeu, logo no início do tratado de harmônica anuncia e busca justificar o conjunto de procedimentos que os praticantes da ciência devem seguir se quiserem produzir bons resultados. Uma comparação com a astronomia é apresentada:

Devemos preservar de todo modo as hipóteses racionais obtidas no cânone, as quais não devem de maneira nenhuma entrar em conflito com as percepções da maioria das pessoas, tal como o propósito do astrônomo é preservar as hipóteses dos movimentos celestes de 
acordo com seus cursos cuidadosamente observados, sendo esses postulados obtidos a partir do fenômeno real e evidente, mas descobrindo cada coisa o mais precisamente possível por meio da razão (Ptolomeu, 2000, p. 7).

Percebe-se que o que está em jogo é a preservação daquilo que é percebido como fenômeno e não a redução de uma aparente irregularidade a uma regularidade que estaria subjacente. Mas ao mesmo tempo, para Ptolomeu, como já dissemos, é crucial utilizar os cálculos para obter maior precisão e para isso, alguma simplificação será necessária. Como chama a atenção Lloyd,

um elemento de simplificação e idealização está presente em toda ciência pois é apenas ignorando algumas características do que está dado que as relações subjacentes que governam os fenômenos podem ser reveladas (Lloyd, 1987, p. 285).

Ptolomeu transforma a própria harmônica em um instrumento de reflexão sobre os métodos e procedimentos científicos, combinando de maneira complexa razão e sensação. Elas são as duas formas de apreensão da harmônica, mas não atuam do mesmo modo, pois "a percepção descobre o que é aproximado e aceita o que é exato, ao passo que a razão aceita o que é aproximado e descobre o que é exato" (Ptolomeu, 2000, p. 3). Ptolomeu critica os pitagóricos e os aristoxenianos, deixando claro para o leitor que não quer ser associado a nenhuma das correntes.

À luz dessas demonstrações, deve-se criticar os pitagóricos, não por sua descoberta das razões das consonâncias, pois eles estão corretos, mas onde eles falharam em atingir seu objetivo. Por outro lado, devese criticar os aristoxenianos, pois eles não concordam que aquelas razões são evidentes e, quando as rejeitam, não procuram outras mais 
seguras, apesar de sua promessa quanto a um estudo teórico da música (Ptolomeu, 2000, p.28).

Para os epicuristas e os estoicos, a percepção era o critério de conhecimento, enquanto que para os céticos, nenhuma das vias poderia alcançar a verdade. Os epicuristas utilizavam o termo cânonica para o "estudo dos critérios pelos quais nós podemos discernir a verdade das coisas da de nossos sentidos" (Cresse, 2010, p. 17). Ptolomeu contempla as duas vias, pitagórica e aristoxeniana, na sua Harmônica, avançando a passos firmes na versão geométrica, embora mantendo o conceito de harmonia pitagóricos, buscando observar o que havia de melhor nas duas vertentes.

Alguns autores, como Crocker (1966, p. 96), consideram que foi Ptolomeu em sua Harmônica que fixou o aristoxenianismo no campo sensorial, sendo essa concepção injustamente perpetuada nos períodos subsequentes. No entanto, considero mais provável que ele apenas tenha feito a referência aos nomes das escolas tal como eram utilizados em seu tempo. Sem contar que na obra ptolomaica a teoria harmônica de Aristóxeno contribui para a problematização do pitagorismo, e vice-versa.

Além disso, Ptolomeu amplia o âmbito das relações tonais para o da física natural. A tarefa da harmônica ptolomaica será identificar os intervalos e as estruturas das escalas e investigar os princípios dessas distinções. O ponto de partida é o exame da qualidade do grave e do agudo no som em geral:

O som é uma tensão contínua do ar que circunda as coisas e é levado para dentro delas produzindo uma perturbação e, portanto, de acordo com o grau de tensão, o som torna-se mais grave ou mais agudo (Ptolomeu, 2000, p. 12). 
Apesar de ser, ao final, o parâmetro da altura que vai interessar ao filósofo para fundamentar a sua teoria musical, até chegar a ela, ele discorre sobre a potência, a ressonância e a distância do som.

A proposta ptolomaica de afinação é central e surge da sua concepção de harmônica e dos critérios que considera que devam ser adotados por quem a investiga, ou seja, um entrelaçamento entre a razão e a percepção. Se a audição e a razão são critérios de avaliação da harmônica, elas não funcionam da mesma maneira. Ptolomeu divide o território. A audição é concernente à matéria (ǔ $\lambda \eta)$ e ao páthos (Tò ná $\theta$ ○), aqui entendido como o páthos do ar. E a razão refere-se à

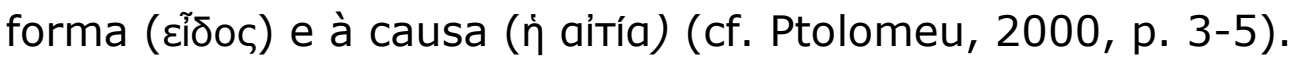

Ptolomeu apresenta a lista mais completa até então das diversas propostas de afinação como a de Arquitas, Eratóstenes, Aristóxeno e Dídimos. Contudo, Ptolomeu não faz apenas um inventário de teorias, pois, seguindo sua metodologia, ele propõe suas próprias afinações a partir da observação cuidadosa nos instrumentos teóricos e práticos e da performance dos citaristas de seu tempo.

Um dos legados ptolomaicos mais importantes é o da afinação sintônica diatônica, que ficou conhecida como afinação justa. Nela, o intervalo de terça é construído pela razão 5:4, que é uma razão epimórica ou superparticular, mas que ficava fora do âmbito da tetraktys pitagórica, por conta do número 5 , condição fundamental para os pitagóricos considerarem o intervalo uma consonância. Como já discutido anteriormente, a afinação pitagórica tinha uma preferência pela quinta justa, razão $3: 2$, por meio da qual eram marcadas todas as outras notas no monocórdio. A inclusão da terça como base da afinação abria uma janela para a gradual dissipação da rígida distinção entre consonância e dissonância.

Ptolomeu faz uma classificação das consonâncias em gradações. Ele considera consonante o intervalo de quarta mais oitava $\left(11^{\mathrm{a}}\right)$, tal como Aristóxeno, e em desacordo com os pitagóricos. As duas primeiras classes ptolomaicas de consonâncias são homófonas - 2:1 
(oitava) e 4:1 (dupla oitava) - e sinfônicas - 3:2 (quinta) e 4:3 (quarta), esta última classe com suas combinações com as homófonas, ou seja, a $11^{a}(8: 3)$ e a $12^{a}$ (3:1). Ptolomeu argumenta a respeito da inclusão da $11^{\text {a }}$ entre as consonâncias:

Que essa razão [8:3] não seja nem epimórica e nem múltipla não nos trará embaraço para nós, na medida em que não adotamos nenhuma hipótese desse tipo anteriormente (2000, p. 23).

A terceira classe de intervalos consonantes ptolomaicos é a

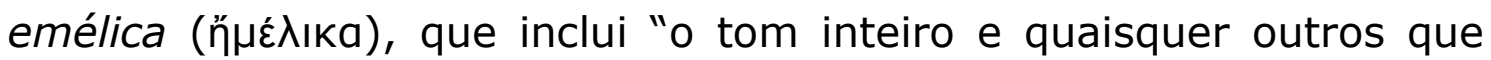
perfaçam a menor das consonâncias, de modo que aquelas sejam razões menores que a sesquitércia [4:3]" (Ptolomeu, 2000, p. 23). Assim, a razão 5:4 está entre as consonâncias emélicas. Essa insinuação da terça maior como consonância levará a desenvolvimentos significativos na prática musical. Contudo, ela só será substancialmente retomada no século XV, já no contexto da música polifônica, por Bartolomeo Ramos de Pareja, em seu livro Musica practica, publicado em Bologna em 1482 e, no século XVI, por Gioseffo Zarlino de maneira mais completa.

\subsection{A geometria musical de Ptolomeu}

$\mathrm{Na}$ história das razões numéricas musicais, a descoberta de Pitágoras foi levada cada vez mais para um contexto quantitativo, buscando responder aos avanços da ciência acústica. São retomadas narrativas como a de Xenócrates, do século IV a.C., da famosa história dos martelos de Pitágoras, reproduzida pelo neopitagórico Nicômaco de Gerasa (60-120 d.C.) em seu Manual de harmônica, e inúmeras vezes durante a Idade Média e início da modernidade. No livro Theorica musicae de Franchino Gaffurio, editado em 1492, Pitágoras é representado em diversas situações de "experimentação" das 
consonâncias. Os experimentos com os martelos, com copos d'água e outros mostraram-se equivocados, e talvez nunca tenham sido feitos, mas o objetivo da narrativa foi alcançado, ou seja, apresentar Pitágoras fazendo experiências acústicas em uma antiga forja.

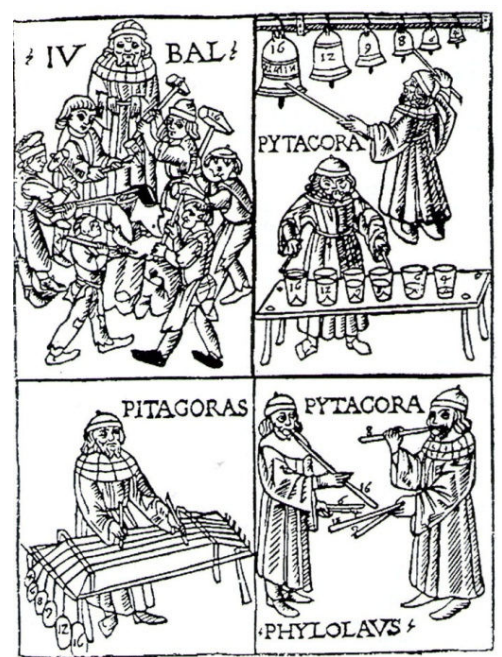

Fig. 94: Os experimentos de Pitágoras em gravura da obra Theorica musicae de Franchino Gaffurio, publicada em 1492.

Os instrumentos e sua manipulação prática desempenham um papel fundamental na harmônica ptolomaica. Logo no primeiro livro, Ptolomeu se diz descontente com o cânone como aparato de investigação e adentra em aspectos da construção de instrumentos e da performance da época. Mas isso é bem diferente da tentativa de Nicômaco de inserir à força as razões numéricas pitagóricas em um quadro pretensamente experimental.

Ptolomeu propõe instrumentos para a investigação dos intervalos musicais, iniciando pela "verificação empírica" em dois instrumentos de sopros, no aulós e na sýrinx, mas percebe que não será possível utilizar esses instrumentos de sopros para cumprir seu objetivo. No mesmo trecho em que trata disso na Harmônica, desqualifica os experimentos pitagóricos com os martelos e outros artefatos:

Devemos desistir de examinar nosso assunto por meio do aulós e da sýrinx ou pesos presos a cordas, pois tais demonstrações não nos 
podem trazer conclusões precisas. Em vez disso, elas convidam à calúnia em suas empreitadas, pois os aulói e as syríngues são difíceis de examinar, e mesmo se suas inconsistências fossem corrigidas, seus limites, que são necessários para a comparação dos comprimentos ainda seriam estabelecidos apenas de maneira vaga. Além disso, na maioria dos instrumentos de sopro há alguma irregularidade no fluxo de ar. Com pesos presos às cordas, elas não se mantêm inalteradas uma em relação às outras. Ademais, é difícil fazer isso com cada corda em relação a si mesma, pois as razões dos pesos não serão adequadas a concordar com os sons produzidos visto que, com a mesma tensão, cordas mais grossas ou mais finas produzem notas mais agudas (Ptolomeu, 2000, p. 24-25).

Será que o fluxo de ar comprimido pelo peso da água tal como se apresentava na hydráulis não seria mais estável e confiável para os experimentos de Ptolomeu? Ou o fato de a hydráulis ser um dispositivo criado pela arte mecânica o indispusesse a utilizá-lo? É difícil compreender o silêncio de Ptolomeu a respeito do órgão, mas ele parece perseguir metas bem definidas. Por exemplo, quando conversa com a tradição, rejeita algumas vias de investigação:

Dificuldades parecidas ocorrem quando sons produzidos por percussão, sons que alguém observe produzidos por martelos de peso desigual ou discos e por recipientes vazios e cheios, pois é, de fato, uma tarefa difícil observar em todos eles constância no que diz respeito à matéria e à forma (Ptolomeu, 2000, p. 25).

No caso dos discos, ele se refere aqui à experiência de Hipaso de Metaponte, do século $V$ a.C, que teria feito experimentos com discos de bronze de mesmo diâmetro, cuja espessura estava na mesma relação das razões das consonâncias; percutindo os discos era possível ouvir as consonâncias. De acordo com Burkert, 
a experiência é fisicamente correta, pois para discos que podem vibrar livremente, o número de vibrações é diretamente proporcional a sua espessura. Portanto, é possível confiar que Hipaso conhecia e tenha experimentado as razões numéricas das consonâncias (apud Szabó, 1977, p. 122).

Ptolomeu remete também a expressões presentes no livro de Nicômaco de Gerasa, que é da geração imediatamente anterior a sua, e que Ptolomeu, em alguns momentos, parece atacar. Na narrativa de Nicômaco, Pitágoras

um dia estava absorto em pensamentos e considerando seriamente se seria possível inventar algum tipo de ajuda instrumental para os ouvidos que fosse firme e sem possibilidade de erro, tal como a visão obtém pelo compasso ou a dióptra; ou o tato obtém com a balança ou o sistema de medidas (1994, p. 83).

A imagem de Nicômaco reaparece na Harmônica de Ptolomeu, mas o argumento para a utilização do cânone é mais sofisticado e não traz referências exteriores ao núcleo da questão.

Para os ouvidos, similarmente, que ao lado dos olhos são os maiores mensageiros da parte racional e teórica da alma, também há necessidade de alguma abordagem racional para lidar com coisas cuja natureza eles [olhos e ouvidos] não são capazes de julgar com precisão. (...) O instrumento desse tipo de abordagem é chamado de cânone harmônico, um termo que vem da sua capacidade de medir e fornecer medições onde a percepção sensível é inadequada para revelar a verdade (Ptolomeu, 2000, p. 6-7).

Ou seja, para que haja uma representação precisa, são necessários aparatos técnicos específicos e Ptolomeu propõe, então, a construção de alguns deles. Na sua Harmônica, seis são os capítulos 
dedicados a descrições detalhadas de suas elaborações, tanto do ponto de vista de suas propriedades quanto de seu design.

Sabe-se que 0 astrolábio armilar foi 0 instrumento mais sofisticado que Ptolomeu utilizou para fazer suas medições astronômicas. No livro 5 da Syntaxis mathematica, ele explica como descreveu a posição da Lua com o astrolábio, instrumento que já existia antes dele, mas do qual ele diz ter construído o seu próprio exemplar (cf. Lloyd, 1990, p. 139). Parece-nos, então, que Ptolomeu tinha uma oficina de trabalho ou dispunha de algum artesão que fizesse esses instrumentos para ele. Quais técnicas de construção estariam disponíveis a Ptolomeu? A sua descrição da construção do cânone é de alguém que, se não construiu o instrumento de fato, acompanhou de muito perto a sua execução. Ela é a mais completa entre os autores antigos: geométrica, detalhada e preocupada com a construção física.

Como chama a atenção Creese, Ptolomeu, na Syntaxis mathematica, introduz seus primeiros instrumentos científicos bem mais tarde que na Harmônica (cf. Creese, 2010, p. 283), o que mostraria que no campo da teoria musical, ele considera impossível avançar sem os instrumentos. Para um matemático como Ptolomeu a determinação precisa dos pontos no cânone era fundamental, mas ele se dedica também à colocação exata dos cavaletes (Fig. 95). Ele não parece estar falando de uma corda ideal, pois dá detalhes da colocação desses cavaletes que devem ser: "em todos os aspectos iguais e similares, com as superfícies debaixo das cordas, o máximo possível, esféricas" (Ptolomeu, 2000, p. 26). Segundo Creese, nessa passagem da construção do kanon, fica claro que quando Ptolomeu diz "o máximo possível, esféricas", está pensando em uma distância entre o cânone e a sua representação pelo diagrama, "pois o geômetra não precisa falar nessa linguagem, [como já disse Aristóxeno]: ele só precisa dizer 'imaginemos duas esferas iguais e ele pode então considerar que elas sejam 'iguais e similares'"' (2010, p. 308). 


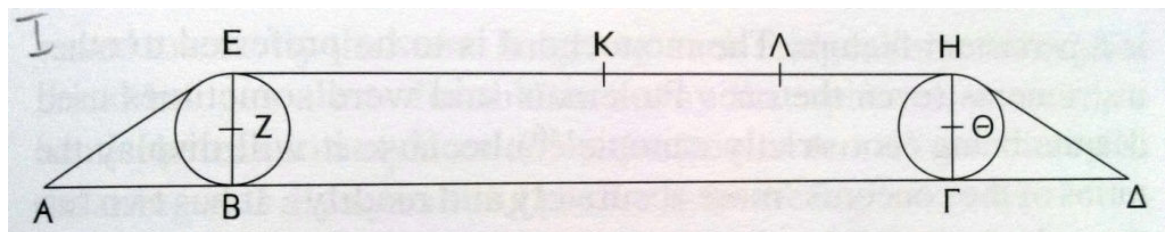

Fig. 95: Diagrama da marcação de pontos precisos no cânone que acompanha a edição de Düring, 1930.

Alguns problemas na construção do cânone haviam sido apontados pelos antigos, como em uma passagem de Adrasto em que é mencionado o fato do cavalete móvel, que faz as marcações debaixo das cordas, possuírem uma largura, o que faria que esse objeto físico tomasse um pouco da medida do comprimento da corda (cf. Creese, 2010, p. 311-15). Mas Ptolomeu é um observador agudo em relação à confiabilidade do julgamento, como vimos, ele escreveu uma pequena obra sobre o assunto. Sendo assim, o cavalete móvel, para Ptolomeu, não tem apenas largura, tem também altura, fazendo com que a corda suba um pouco, originando uma pequena curva, e modificando a medição do comprimento da corda (Fig. 96).

Ptolomeu enfrenta esse problema, mas utiliza a própria geometria para defender que, como os cavaletes fixos são circulares, haveria uma compensação para o lado (cf. Ptolomeu, 2000, p. 137).

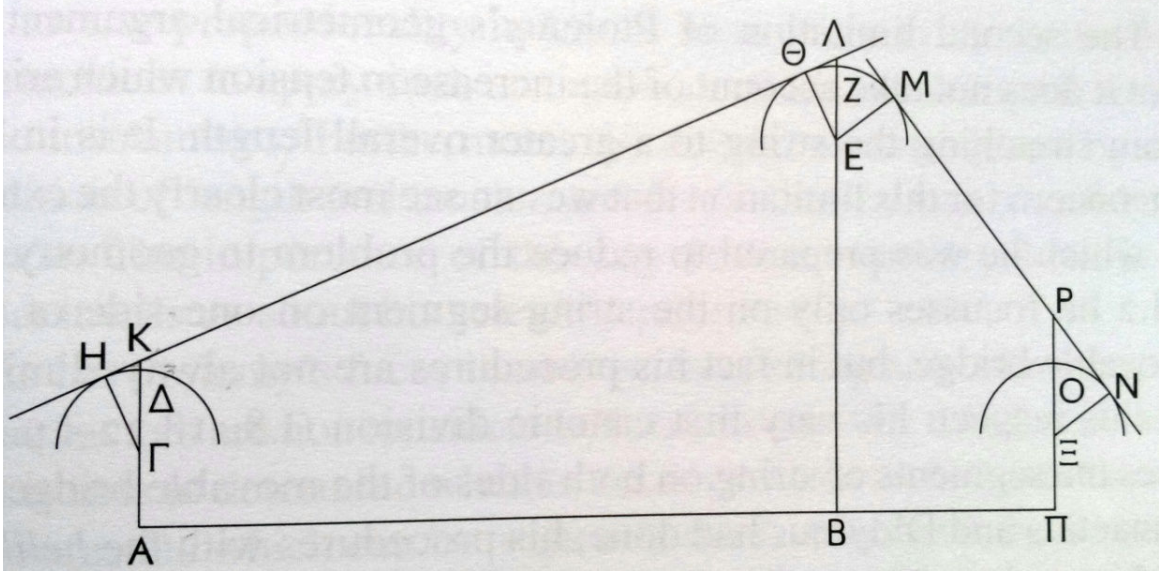

Fig. 96: Diagrama indicando o desvio da corda, que acompanha a edição de Düring, 1930. 
O argumento de Ptolomeu não se sustenta (cf. Creese, 2010, p. 312-4), pois ao mudar o comprimento de cada lado da corda, modificase o seu ponto de tensão. Ele não tinha instrumentos de medição acústica que pudessem observar a alteração, contudo, o que é importante é que Ptolomeu considera que a variação perceptível ao ouvido é que deverá contar ao final: "O teste é a perceptibilidade. Ptolomeu não nega que exista uma discrepância entre o físico e o ideal, mas ela só é relevante para o téorico se distorcer os resultados a um grau perceptível" (Creese, 2010, p. 316).

A corda subir levemente, esticando um pouco para cima não altera a percepção auditiva, portanto a diferença visual não é levada em consideração. O mais importante nessa passagem é que Ptolomeu registra e enfrenta o fato de que o diagrama não possa representar alguns parâmetros. Seus instrumentos são artefatos, já fora do papel, mas a geometria ainda faz com que eles não escapem do seu modelo. O monocórdio pode ser representado diagramaticamente, mas o instrumento e o diagrama nunca serão idênticos. Depois de Ptolomeu, nunca mais as cordas deveriam ser representadas por linhas, de maneira incólume.

Quando Ptolomeu propõe um instrumento de oito cordas, ele sabe da impossibilidade, em seu tempo, de conseguir oito cordas de espessura igual. Mas isso não será necessário para o experimento, pois, para ele, é a tensão que deve ser igual.

Existem três razões para a diferença entre o agudo e o grave - a densidade, o diâmetro e o comprimento das cordas. Os sons mais agudos resultam de uma corda mais densa, mais fina e mais curta; a tensão faz aqui o papel da densidade, pois ela cria tensão e dificulta também o que poderia ser similar a uma corda mais curta (Ptolomeu, 2000, p. 37-38). 
Como diz Barker, "a descrição de Ptolomeu do cânone é certamente adequada para oferecer a um luthier toda a informação necessária para construir um e colocá-lo em uso" (Barker, 2000, p. 203).

No Livro I da Harmônica, particularmente no oitavo capítulo, intitulado "De que modo as razões das consonâncias serão demonstradas fielmente no monocórdio cânone", o cientista parte das razões matemáticas para o instrumento. No livro 2, o caminho é inverso: "Como as razões das consonâncias nos gêneros conhecidos devem ser reconhecidos também pelos sentidos".

Examinemos agora de uma outra forma aqueles gêneros costumeiros e facilmente apreciados pelo ouvido. Não da mesma forma como fizemos até agora, produzindo as diferenças das razões e depois testando-as no kanon, confrontando com a evidência que surge aos ouvidos, mas da maneira oposta, primeiro achando as afinações a partir da audição e depois demonstrando as razões delas. Assumindo os intervalos reais utilizados pelos citaristas e demonstrando as razões que os descrevem (Ptolomeu, 2000, p. 60).

Mais adiante, Ptolomeu já não vai considerar o cânone, monocorde ou policorde, adequado como instrumento de observação, pois a afinação é alcançada pelo deslizar sucessivo desses cavaletes pela corda e

(...) se a estrutura está bem fixada e o cavalete move-se lentamente, as notas podem ser comparadas razoavelmente bem, mas se ele tiver de ser movido mais rapidamente, de acordo com a progressão da melodia ou do ritmo, o resultado não será similar (Ptolomeu, 2000, p. 93).

Sendo assim, é necessário utilizar um instrumento advindo da prática musical como a cítara, pois no cânone 
as mãos afinam e tocam o instrumento separadamente e, desse modo, somos desprovidos da mais bela das técnicas de tocar um instrumento como o trilo, ziguezagues para cima e para baixo, empurrar as cordas e tocar em saltos separados, entre outros (Ptolomeu, 2000, p. 94).

Em alguns trechos, Ptolomeu parece estar utilizando o princípio da continuidade (synechéia) de Aristóxeno, que propõe que a avaliação do intervalo deva ocorrer no interior da escala (cf. Bélis, 1986a, p. 139146), mas parece ir além pois investiga os intervalos em melodias e afinações de fato, que eram utilizadas na prática dos citaristas de seu tempo. Para ele, as relações musicais "erradas" são mais fáceis de ser reconhecidas nas melodias do que em uma escala. Como sublinha Barker,

nenhum outro autor grego de harmônica matemática, que eu saiba, mostrou algum sinal de apreciar a necessidade de apresentar afinações para o ouvido crítico acessar, não como estruturas ou escalas, mas em melodias verdadeiras (Barker, 2000, p. 206).

Após as experiências com o cânone e a cítara, Ptolomeu apresenta um novo instrumento, o hélicon, que ele diz ser de uso comum entre os matemáticos (cf. Ptolomeu, 2000, p. 66-67). Nele, as médias harmônica e aritmética serão apresentadas nas suas versões geométricas. O processo de construção do hélicon é simples (Fig. 97 a 102). Trata-se de um quadrado, de madeira, por exemplo, em que são fixadas quatro cordas (Fig. 97a-d). 

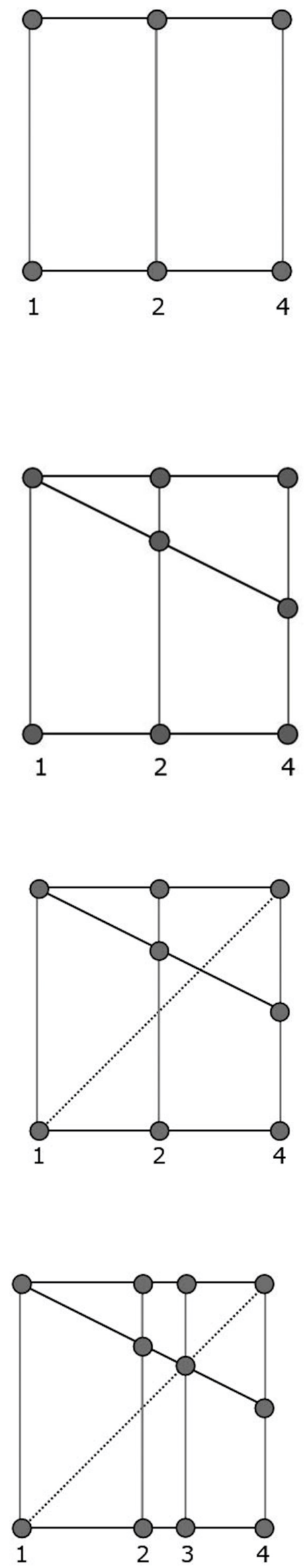

Fig. 97a: Primeiro passo da construção do hélicon: a corda 2 é fixada exatamente no centro entre a corda 1 e a corda 4.

Fig. 97b: Segundo passo da construção do hélicon: um suporte é colocado atrás das cordas, tomando como referência o ponto de fixação superior da corda 1 e a metade da corda 4.

Fig. 97c: Terceiro passo da construção do hélicon: Uma diagonal puramente teórica é traçada entre o ponto inferior de fixação da corda 1 até o ponto superior de fixação da corda 4.

Fig. 97d: Quarto passo da construção do hélicon: A corda 3 é fixada no local determinado pelo ponto de encontro do suporte traseiro com a diagonal teórica. Desse modo, seu ponto de fixação corresponde ao que seria encontrado pelo cálculo da média harmônica, mas ele é encontrado de maneira puramente geométrica, sem a necessidade da aritmética. 
Os intervalos de quarta (Fig. 98), quinta (Fig. 99), oitava (Fig. 100) e tom inteiro (Fig. 101) poderão ser ouvidos formados pelo cruzamento do suporte com essas cordas, além da 11a. (quarta +oitava) / 12a. (quinta + oitava) e a 15a (dupla oitava) (Fig. 102). Note-se que, nesse caso, não há necessidade de mover cavaletes e, além disso, todo o sistema pode ser visualizado simultaneamente, sem contar o fato de que as cordas podem ser tocadas juntas, como nos instrumentos musicais, mas de modo controlado. Na figura abaixo estão em destaque, as cordas tangidas e os respectivos intervalos obtidos. Os pontos representam os lugares de fixação dos segmentos de cordas no suporte traseiro.
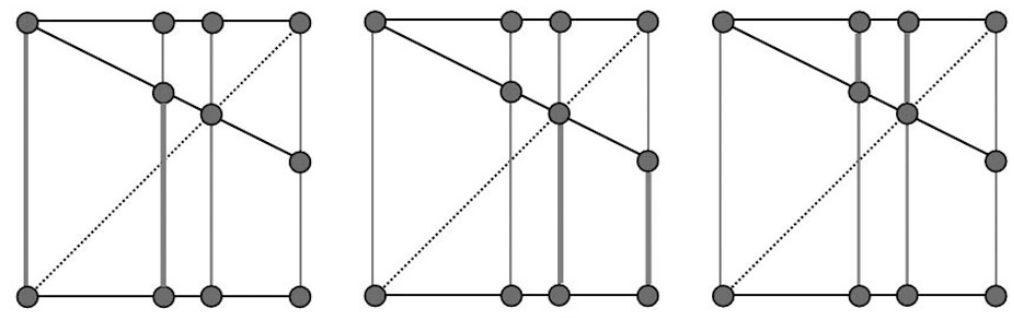

Fig. 98: Quartas: corda 1 + segmento corda 2; segmento corda 3 + segmento corda 4; segmentos superiores cordas 3 e 2 .
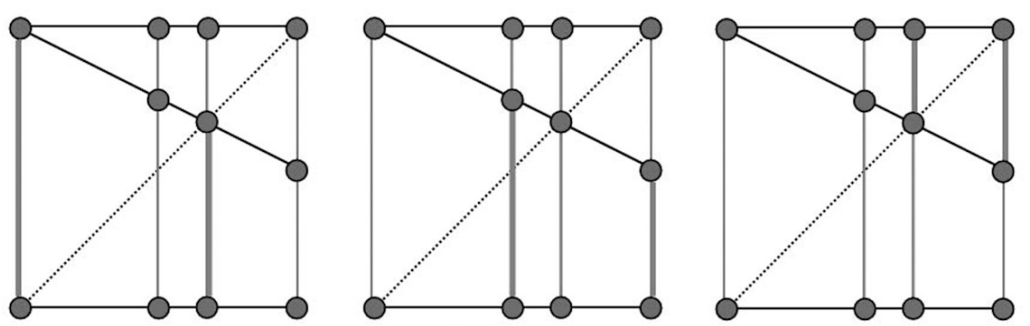

Fig. 99: Quintas: corda 1 + segmento corda 3; segmento corda 2 + segmento corda 4; segmentos superiores cordas 4 e 3 . 

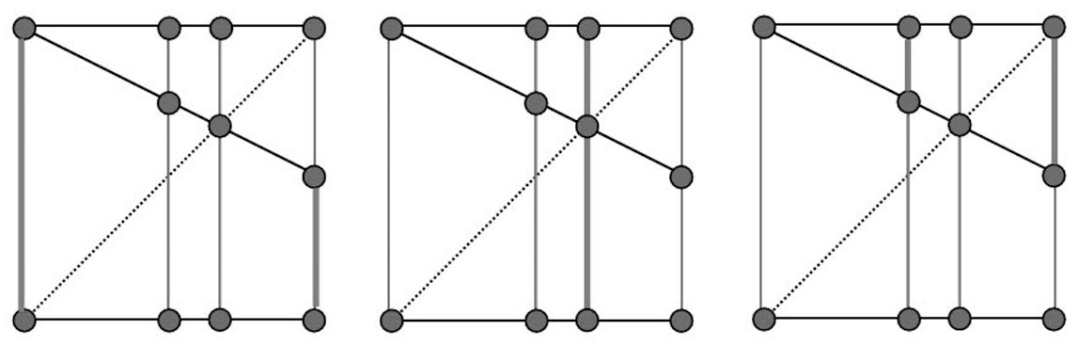

Fig. 100: Oitavas: corda 1 + segmento corda 4; segmento corda 3 + segmento superior corda 3; segmentos superiores cordas 4 e 2.

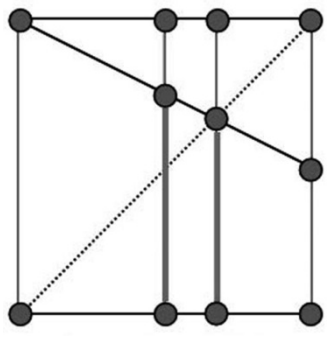

Fig. 101: Tom: segmento corda 2+segmento corda 3.
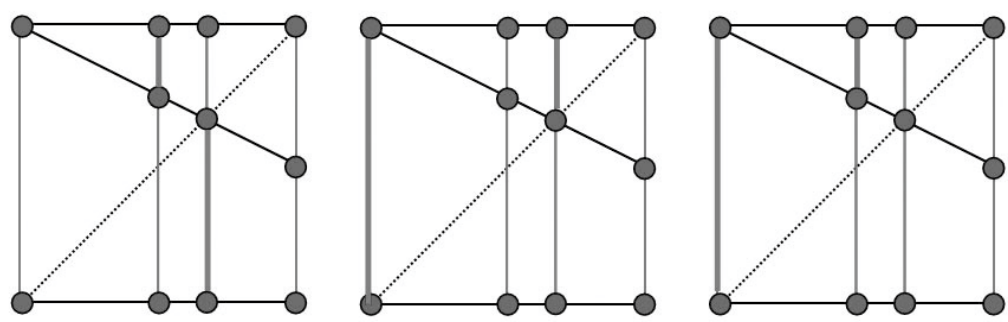

Fig. 102: $11^{\text {a }}$ (segemento inferior da corda $3+$ superior da 2); $12^{\text {a }}$ (corda $1+$ segmento superior da corda 3 ) e $15^{a}$ (corda $1+$ segmento superior da corda 2 ).

Como diz Creese,

os postulados fundamentais da ciência [harmônica] ainda são firmemente governados pela aritmética, mas os instrumentos em si mesmos, nunca haviam sido mais claramente geométricos que nas mãos de Ptolomeu (Creese, 2010, p. 15). 
O hélicon é um diagrama musical materializado e pode ter nascido da necessidade de observação dos limites entre os objetos físicos e ideais. Mas parece ser apresentado apenas como uma introdução ao instrumento que vem a seguir que dev ser, de fato, uma invenção de Ptolomeu (Fig. 103).

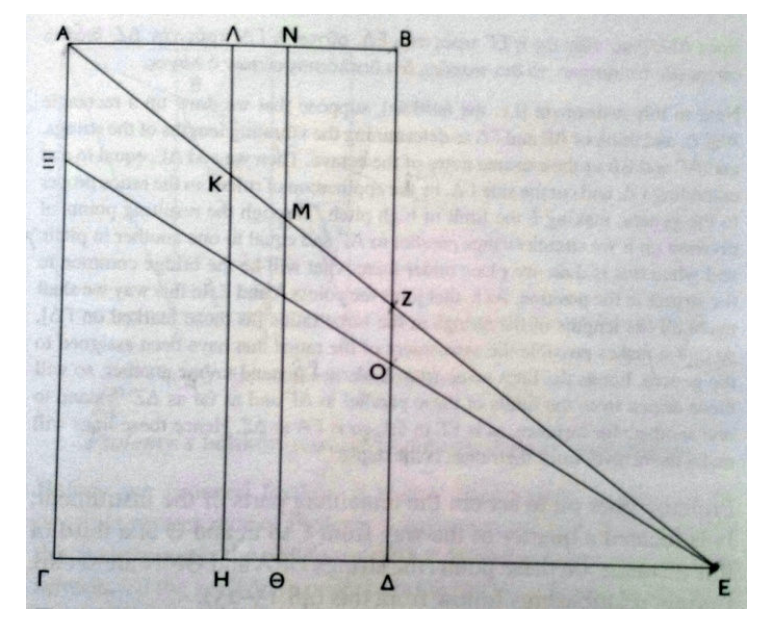

Fig.103: Diagrama acompanhando a edição de Düring, 1930 mostrando a variante do hélicon, permitindo a formação das seguintes proporções:

$$
\begin{aligned}
& \mathrm{A} \Gamma: H K=4: 3 \text { (quarta) } \\
& \Theta M: \Delta Z=4: 3 \text { (quarta) } \\
& \mathrm{A} \Gamma: \Theta M=3: 2 \text { (quinta) } \\
& \mathrm{HK}: \Theta Z=3: 2 \text { (quinta) } \\
& \mathrm{HK}: \Theta M=9: 8 \text { (tom) }
\end{aligned}
$$

Esse novo instrumento é um paralelogramo retangular em que são fixadas as cordas AG e BD. Em seguida, toma-se o comprimento de GD e marca-se o ponto homotético E fora do retângulo. Nesse ponto $E$ é instalado um cavalete móvel, pivotante em E. Marca-se então no cânon GD as razões próprias gênero que se desejar, diatônico, enarmônico ou cromático, de modo que H é 1/4 de GE e TH, 1/3 de GE. Desse modo, será possível mover o cavalete para cima e para baixo 
fazendo transposições de tom "enquanto as características do gênero permanecem inalteradas" (Ptolomeu, 2000, p. 68). Ptolomeu dá os detalhes musicais, materiais e geométricos de sua construção. Cada elemento tem uma função concreta, como observa Barker: "Enquanto a passagem do hélicon parece saída de um tratado de geometria, esse segundo instrumento parece mais um manual de como construir seu próprio instrumento" (2000, p. 210).

O plano horizontal está para o vertical por meio da diagonal, que no caso, é um cavalete móvel. As relações entre as distâncias verticais e horizontais são proporcionais, assim, alterando a posição lateral das cordas e movendo o cavalete, não há alteração na configuração das relações.

Creese explica o funcionamento do instrumento, que é uma variante do hélicon:

Uma afinação, uma vez estabelecida, poderia ser transposta para combinar com uma tessitura existente de um instrumento de performance com uma lira ou uma kithára, talvez com o objetivo de tornar os intervalos de uma afinação proposta mais fáceis de julgar: o citarista pode afinar seu instrumento pelos intervalos da variante do hélicon e então tocar melodias nessas afinações sem sacrificar a familiaridade com seu instrumento usual (2010, p. 340).

Não temos razões para duvidar que essa variante do hélicon tenha sido uma invenção de Ptolomeu, mas tudo indica que ele tenha se inspirado no mesolábio do geógrafo do período alexandrino Eratóstenes de Cirene. Além de serem parecidos, tanto a variante do hélicon quanto o mesolábio operam sobre princípios matemáticos similares e executam uma tarefa semelhante. $O$ instrumento de Ptolomeu não encontra médias aritméticas ou harmônicas, apenas as mostra, pois elas já são conhecidas, mas os dois instrumentos utilizam 
a diagonal para fazer com que as relações entre as linhas horizontais e as verticais sejam análogas.

O termo mesolábio vem do grego e é formado pelo adjetivo

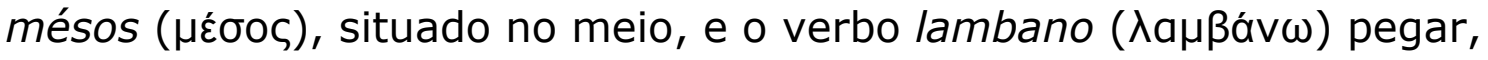
tomar. O instrumento constituía-se de três taboinhas que corriam uma sobre a outra e, desse modo, permitia a inserção mecânica de médias proporcionais nas cordas. Do vértice superior esquerdo do primeiro quadrado até o vértice inferior esquerdo do terceiro colocava-se um fio ou corda com um peso na extremidade. Dois quadrados possuíam uma diagonal da esquerda para a direita (Fig. 104a-b).

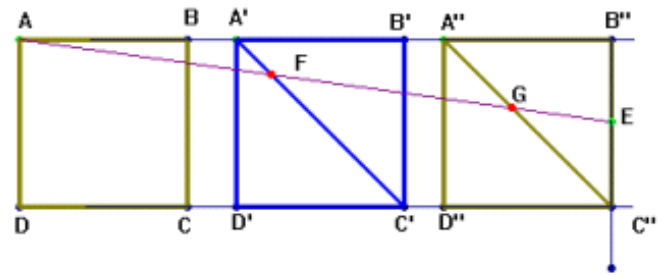

Fig. 104a: O primeiro quadrado à esquerda permanece imóvel, enquanto os outros dois se movem, formando relações verticais e horizontais nas proporções desejadas (Fig. 104 b).

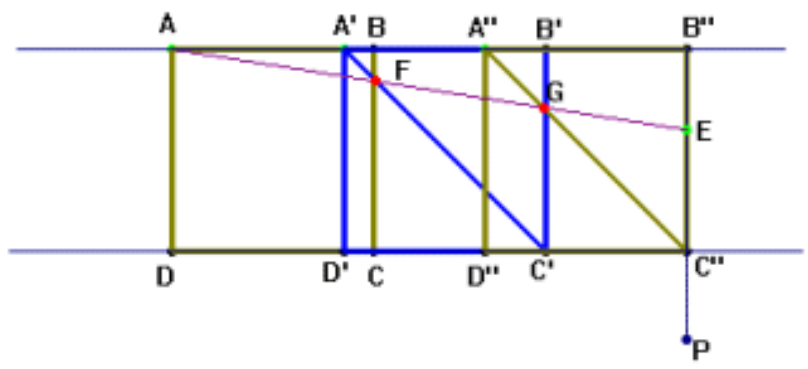

Fig. 104b: Mesolábio na posição final.

Ptolomeu não menciona o mesolábio, mas é importante indicar aqui essa relação que, além de mostrar o contexto matemático da obra de Ptolomeu, nos faz compreender porque esse instrumento vai ser retomado na Renascença pelo matemático Giorgio Valla (1447-1500) e depois pelo organista espanhol Francesco Salinas (1513-1590). Salinas sugere o mesolábio como dispositivo para dividir a oitava em 
12 meios tons e de acordo com Salinas, esse era o método utilizado pelos fabricantes de violas (cf. Barbour, 2004, p. 50-1).

A partir do seu instrumento derivado do hélicon, Ptolomeu percebe que era possível controlar os intervalos pela relação lateral entre as cordas, em vez de colocar um cavalete separado para cada corda. Ele vai experimentar essa inovação tecnológica em seus cânones expandidos, com várias cordas. Nesses instrumentos, ele sugere a colocação dos kollaboi (ò kó $\lambda \lambda a ß o s)$, que era um desenvolvimento dos antigos kollópes. Bélis nos fornece a história da transformação desse dispositivo do período arcaico ao helenístico.

O sistema de fixação mais antigo foi o dos kollópes, peças grossas de couro fervido cortados da nuca de boi, depois em madeira (kollabói), substituídas desde o fim da era helenística por verdadeiras chaves de afinação espetadas no travessão, os passalískoi, de madeira, de osso ou de marfim (2000, p. 206).

Ptolomeu sugere colocar as kollaboi, ou passaliskoi (òl

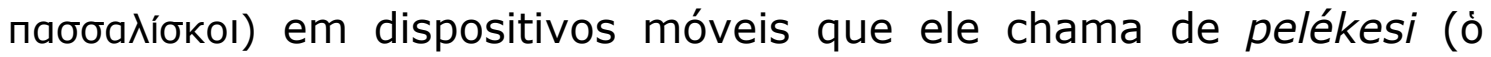
п $\lambda \varepsilon \dot{\kappa} \varepsilon \sigma ।$ ) (cf. Barker, 2000, p. 211-2), e assim, as cordas podiam se movimentar lateralmente. Isso será importante para seus cânones policordes. Por exemplo, com o cânone de oito cordas será possível tocar todas as notas da oitava em várias construções diferentes de escalas.

Para fins teóricos, uma oitava era suficiente mas para que se pudesse observar o comportamento das afinações no contexto de performance, Ptolomeu, novamente, não considera isso suficiente, pois deveria ser utilizado o sistema de oitava dupla para se produzir as

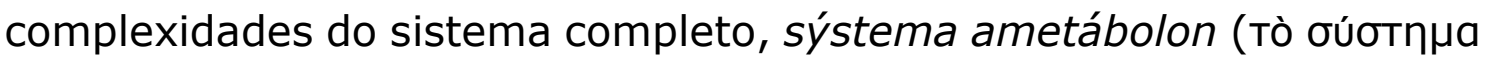

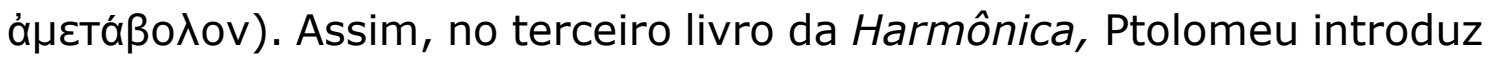
um cânone de 15 cordas, que era um instrumento de uso corrente em seu tempo, em especial para as demonstrações de harmônica. Talvez 
exatamente por necessitar de volume de som para essas demonstrações, ele indica um cuidado especial com as cordas mais curtas, para que elas não percam em sonoridade. Para isso, ele aconselha utilizar cordas de espessura diferente retomando o ponto de vista físico acústico que havia sido apresentado no início da obra quando discutiu as causas do agudo e do grave no som (I.3 [6.14 a 9.13]). Creese comenta que o instrumento de 15 cordas poderia ser utilizado como um afinador.

Esse kánon maior, diz Ptolomeu, é útil para os que quase não tem ouvido musical; na medida em que qualquer um é capaz de afinar notas em uníssono ( $e$, consequentemente, em oitavas), as posições do cavalete podem ser encontradas pela mensuração no kanónion e a afinação correta ser ouvida. Podemos imaginar se Ptolomeu considerou o uso desse instrumento como um expediente para o estudante de lira que tinha dificuldade em afinar o seu instrumento, tal como hoje os afinadores eletrônicos modernos usados pelos instrumentistas de cordas que não conseguem afinar suas quintas ${ }^{37}$ de ouvido (Creese, 2010, p. 347).

Assim como os instrumentos astronômicos utilizados por Ptolomeu foram essenciais para acompanhar e medir a posição e o movimento dos planetas, na harmônica, eles têm a função de determinar as posições e os movimentos dos tons dentro dos sistemas, das escalas. Mas o kánon, além de funcionar como instrumento de representação e de analogia, é ao mesmo tempo uma ferramenta de geração e manipulação física do som. Seu trabalho não termina com a mensuração, ele segue sobre a mesa. Ele deve guiar nossos sentidos, porque a natureza é racional e ordenada, mas ele se comunica simultaneamente com a visão e audição, que são, para Ptolomeu, ai

\footnotetext{
37 Quintas, no caso dos instrumentos da família dos violinos, quartas, para o violão.
} 
ton logikóteron aisthéton, os mais racionais dos sentidos (aï Tũv

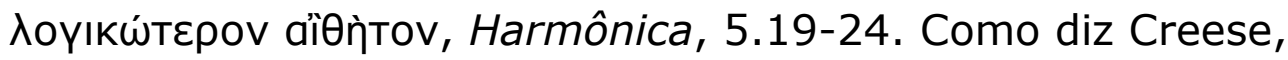

a abordagem de Ptolomeu é tanto crítica quanto criativa, ele trouxe para a harmônica ferramentas de outras ciências - a notação sexagesimal dos astrônomos, o hélicon dos matemáticos e os modificou para adequá-los a seu projeto. Mas a sua principal dívida com o passado certamente é o kánon, sem o qual o seu projeto nunca poderia ser realizado. Como o ábaco, ele permite a manipulação de quantidades perceptíveis; como a régua e o compasso, ele pode ser usado para construir essas quantidades perceptíveis por meio de distâncias; como o diagrama geométrico, ele faz a mediação entre o reino do número e o reino da percepção - o reino do ser e o reino do vir a ser. Mas diferente de todos esses, ele fala plenamente, diretamente e simultaneamente à visão e à audição, os dois sentidos que Ptolomeu considera como "os sentidos especialmente servidores da parte racional e teórica da alma" (Harm. 5. 7-8, Creese, 2010, p. 349).

\subsection{O céu musical de Ptolomeu}

No livro 3 da Harmônica, Ptolomeu afirma que mostrou suficientemente seus argumentos nos dois primeiros livros e que isso aconteceu devido "às razões apropriadas de suas hipóteses e à luz do controle da performance real" (Ptolomeu, 2000, p. 138). Nesse livro final, o autor deixará claro que, para ele, as hipóteses a partir das quais procedia a sua demonstração argumentativa eram os fundamentos inerentes ao próprio universo. O objetivo da sua harmônica é nos prover de ferramentas de abordagem e interação com o mundo, possibilitando a observação dos princípios subjacentes àquilo que é perceptível.

De acordo com Long, algumas passagens da Harmônica conectam-se diretamente ao livro Sobre o critério. Por exemplo, nesse 
terceiro livro da Harmônica, no qual Ptolomeu discute conceitos como éthos, proporção, divindade, beleza natural e alma. Para Long, o esquema de correspondências que ele desenvolve, relacionando intervalos musicais às partes inteligentes da alma, "coincidem exatamente com a sua análise dos constituintes do pensamento de Sobre o critério" (1996, p.204).

Para Ptolomeu, as afinações e as notas devem ser encontradas na natureza, senão não será possível encontrar a harmonia "oculta" ao ouvi-las, nem poderão ser repetidas eterna e identicamente, seja nos sistemas musicais, pela alma humana ou no sistema planetário. 0 sistema de correspondências entre astronomia e harmônica se desenvolve magistralmente em capítulos intitulados Como a sucessão das notas é similar ao movimento longitudinal das estrelas, Como o movimento das estrelas em altitude é comparável aos gêneros harmônicos ou Da similaridade dos tetracordes com os aspectos do Sol.

No capítulo 8, Ptolomeu diz que os tons podem dar a impressão de caminhar de acordo com o tempo, como sobre uma reta, "mas as funções e as relações recíprocas, que são as características próprias do som, são delimitadas e fechadas em uma única órbita, segundo um movimento de tipo circular" (8.25, p. 220). Ptolomeu propõe uma comunicação entre a escala do grande sistema perfeito grego e as configurações dos astros e estabelece o movimento circular e a recorrência cíclica como características das duas ciências: o movimento harmônico parece reto mas é cíclico, como o dos corpos celestes, e tal como o sistema sexagesimal dos astrônomos (Fig. 105a-b). E mais, em termos da sua dýnamis, as notas do systémata formam um círculo fechado, sem ponto de partida. Não há como alguém que tendo experienciado a tonalidade tal como se constituiu no Ocidente, não fazer as conexões entre o sistema proposto por Ptolomeu e o sistema tonal, fechado em intervalos de quintas justas, que será teorizado por Jean-Philppe Rameau na primeira metade do século XVIII. 


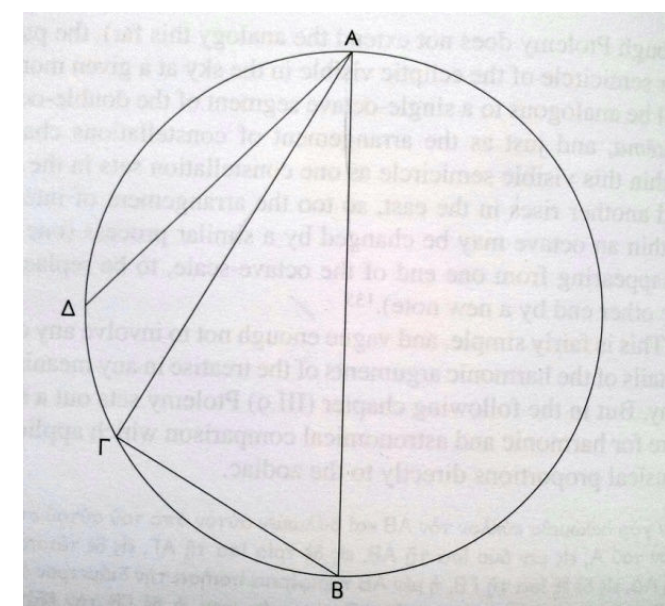

$A_{I}$

$\Delta \Gamma$

B

Fig. 105a-b: Diagramas que acompanham a edição de Düring, 1930. O primeiro mostra a divisão do círculo em 2, 3 e 4 partes iguais. O segundo mostra a versão em linha reta do círculo que foi dividido, agora na forma de um kánon.

A ciência harmônica ptolomaica tem a tarefa de identificar os intervalos e as afinações do sistema grego, definindo o que é musical, ou seja, o que é belo sonoramente. Mas essa primeira etapa só é possível porque há uma coerência inteligível, matemática, na própria estrutura do universo. Os princípios da harmônica são os mesmos da astronomia e da cosmologia ptolomaica.

Nessa correspondência de apreensão das estruturas, que

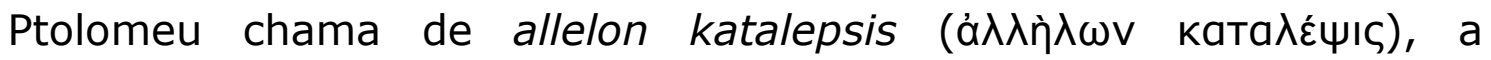
simplicidade tem um papel importante: "Nós deveríamos buscar adaptar as hipóteses mais simples, na medida do possível, aos movimentos celestes, e se isso não der certo, tentar outras hipóteses possíveis" (Syntaxis matematica, Livro XIII, cap. 2 apud Lloyd, 1990, p. 150). Nesse sentido da busca pela simplicidade das teorias é que Lloyd diz que há uma "continuidade essencial na teoria astronômica desde Ptolomeu até Copérnico, passando pelos astrônomos árabes" (1990, p. 151).

De fato, o estudo atento da Harmônica de Ptolomeu mostra que ela é, na verdade, sua obra mais completa e, se de fato for a última, 
vem coroar o conjunto dela. Ali está reunido todo o seu conhecimento de música, acústica, matemática, física, astronomia, astrologia e filosofia.

A Harmônica foi comentada por Porfírio, servindo assim de fonte a Boécio no século VI d.C. No século $X$, na Síria, Al Farabi também se interessou pela obra, tal como farão os bizantinos, responsáveis por sua preservação. No século XV, na Itália, Franchino Gaffurio a retoma em seu livro De harmonia musicorum instrumentorum, e Gioseffo Zarlino, em meados do século seguinte, aprofunda as questões em um contexto musical bastante diverso, na obra Instituições Musicais. No século XVII, a harmonia ptlomaica está presente na Harmonices Mundi de Johannes Kepler. A obra situa-se agora no centro de uma discussão acalorada entre cientistas, músicos e teóricos do Renascimento. O debate é acerca da questão da combinação ou não entre análise teórica e prática real, mas o que está em jogo, de fato, é a noção de harmonia universal.

Dahlhaus e Katz consideram que Ptolomeu tenha ensaiado rompimentos com a teoria dos intervalos matemático-ontológica, mas recuado no "passo final" ao dar-se conta de que com o abandono das premissas pitagóricas mencionadas, havia o risco de não haver mais limites. "Se 5:4 é uma consonância, por que não 6:5, 7:6, 8:7 e etc., ad infinitum?" (Dahlhaus/Katz, 1989, p. 268). Contudo, os autores concordam que seria "presunçoso culpar Ptolomeu por isso, por negarse às consequências fatais daquilo que parece que intuiu" (Dahlhaus/Katz, 1989, p. 268).

Ptolomeu buscou satisfazer os clamores da ratio assim como do sensus. E ele fez isso forçando sua crítica a uma escola da teoria musical até o ponto em que prova-se necessário que ela seja complementada pela outra (1989, p. 267). 
Ptolomeu foi um verdadeiro coletor de dados e um dos maiores virtuoses do cálculo da Antiguidade, embora criticado por seus erros de observação (cf. Solomon, 2000, p. xxviii, n. 32). A expansão marítima e os avanços técnicos de observação levaram ao declínio da astronomia ptolomaica, assim como de sua geografia. Contudo, no caso da harmônica, a coleta de dados é muito mais simples de ser feita e a sua representação não se transformou estruturalmente ao longo de milênios. Até hoje estão presentes na teoria musical sistemas de organização herdeiros da harmônica aristoxeniana e da ptolomaica. Tudo isso leva a Harmônica de Ptolomeu a uma posição mais perene que o restante de sua obra. Ela não é, definitivamente, uma obra menor de Ptolomeu, ela é o seu poema da harmonia universal, tal como a conceberam os antigos. Ela não é um tratado a respeito de uma ciência particular, mas sobre a totalidade da filosofia, investigação da natureza, especulação e saber ptolomaicos. 


\section{Capítulo 7 - A HERANÇA TÉCNICA DA ANTIGUIDADE}

\subsection{O teclado}

No século II d.C. conviviam dois modelos diferentes de órgão no que diz respeito à produção de ar: o hidráulico e o de foles. Pólux, escritor desse período, nascido em Naucrátis, no Egito, menciona os dois tipos de hydráulis, que ele chama de aulós tirrênico.

Em contraste, o aulós tirrênico parece uma sýrinx invertida. Seus tubos são de bronze, e ele recebe sua reserva de ar por debaixo. O menor desses instrumentos é alimentado por foles; enquanto nos instrumentos maiores uma corrente de ar é produzida pela água empurrada para cima. O segundo instrumento tem a capacidade de

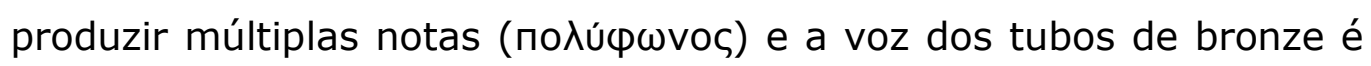
mais forte (Pólux, Onomasticon, iv, 69-70, apud Perrot, p. 93).

O segundo instrumento é a hydráulis tal como descrita por Filo, Hero e Vitrúvio e que mantinha o posto de estrela das grandes apresentações, pelo volume de som e pela atmosfera de magia que suscitava o seu mecanismo. O órgão de foles tinha menos volume de som e era mais utilizado em ambientes domésticos. Mas percebe-se que Pólux, assim como Nicômaco e Ptolomeu, sublinha o mecanismo de produção de ar, e não dá importância ao mais importante avanço tecnológico que trouxe o instrumento: seu teclado. Como diz Meùus:

O teclado tem sua origem provavelmente na hydráulis, mas seu papel na Antiguidade e nas civilizações não-europeias parece ter sido tão limitado que ele pode ser considerado como característico da música ocidental. A primazia da escala de dó maior na música tonal, por exemplo, é em parte devido a ela ser tocada nas teclas brancas, e a escala cromática de 12 semitons, que é fundamental para a música ocidental mesmo em alguns de seus desenvolvimentos recentes, deriva em parte de limitações e necessidades do design do teclado. $O$ arranjo 
das teclas em duas séries, os sustenidos e os bemóis agrupados em dois e três na série de cima, já existia no começo do século XV (2015, p.1).

As ilustrações do teclado são raras, pois em geral a hydráulis era representada de frente pelos artistas e a cisterna ocultava a sua visão. Mas uma terracota do século II descoberta em Cartago, em 1885, mostra um órgão hidráulico em que é possível ver o teclado (Fig. 106). A pequena escultura, que Delattre classificou como um "brinquedo de criança" (apud Perrot, 1971, p. 96), segue a descrição de Vitrúvio, pois vemos "dezoito teclas oblongas, alinhadas exatamente com os tubos" (Perrot, 1971, p. 97). A frente da câmara de ar é assinada com o nome Possessor; um recipiente de óleo no interior oco do instrumento revelou que o artefato era uma lâmpada feita pelo conhecido artesão de lâmpadas Pullaen Possessor (cf. Perrot, 1971, p. 97-8).

Além do valor inestimável de poder enxergar em três dimensões, e perceber que a pequena miniatura em terracota concide exatamente com a descrição de Vitrúvio, essa é mais uma evidência do cuidado que os artesãos tinham com o design de seus artefatos, assim como a inserção e apreço que a hydráulis tinha na sociedade do tempo de Ptolomeu e Nicômaco, aparentemente, até o ponto de os cidadãos desejarem ter uma lâmpada que Ihes recordassem o instrumento. 

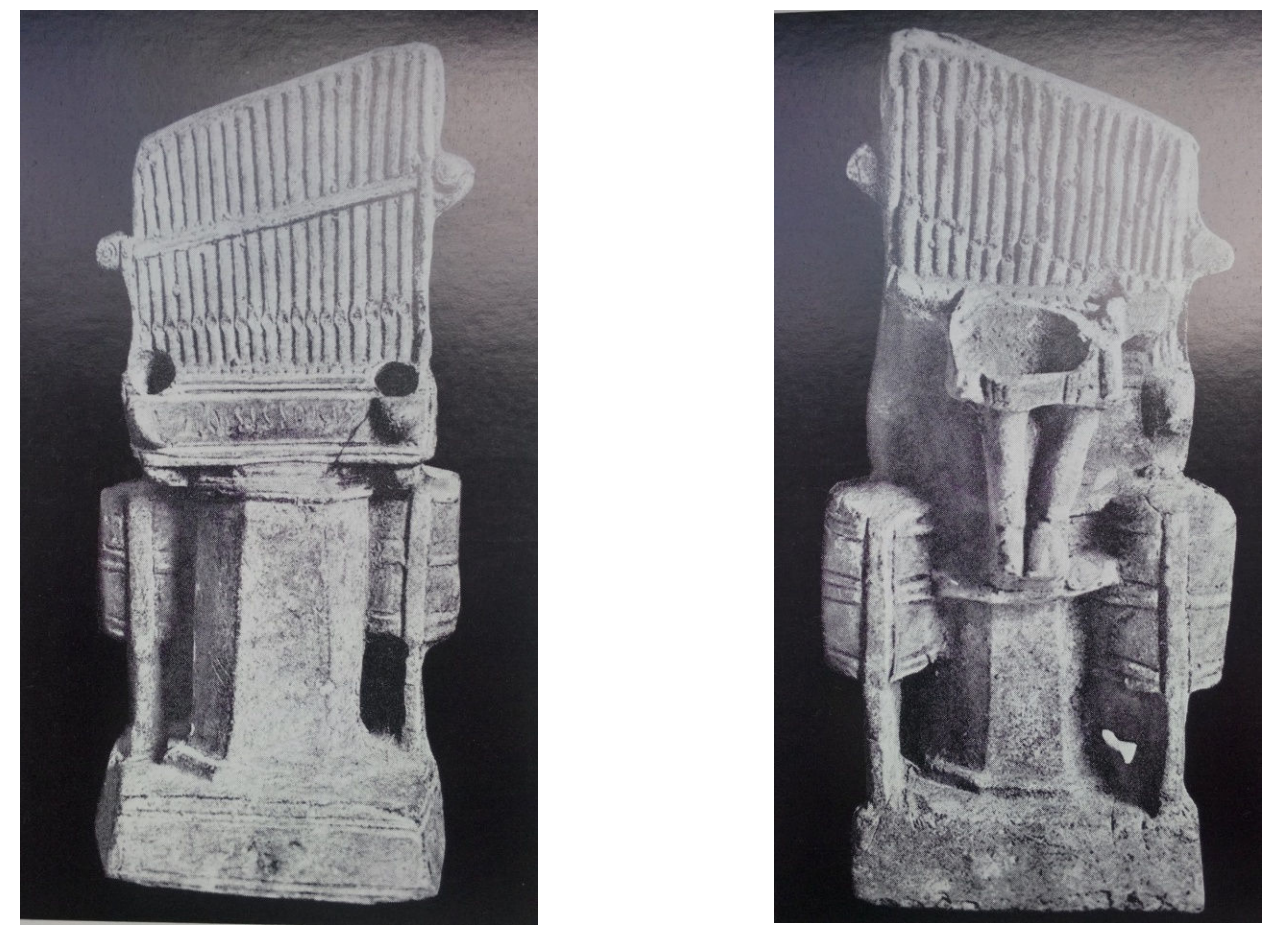

Fig. 106: Lâmpada em terracota, com local para colocar óleo, reproduzindo uma hydráulis em miniatura, vista de frente e de costas.

A maior descoberta arqueológica da história do órgão foi feita em 1931 na cidade romana de Aquincum, hoje na Hungria. Trata-se de um pequeno órgão para uso doméstico, descoberto nas ruínas de uma guilda de tecelões do século III. Um incêndio destruiu o Collegium Centonariorum que possuía esse pequeno órgão em uma de suas salas. Todas as peças de madeira e couro do instrumento foram destruídas, mas as de metal puderam ser reconstituídas: uma parte da câmara de ar, que era de madeira, mas coberta internamente de placas finas de bronze, um conjunto quase completo de tubos e treze lâminas deslizantes com quatro orifícios em cada uma delas, destinado a coincidir com os tubos do órgão (Fig. 107). Essas lâminas são as

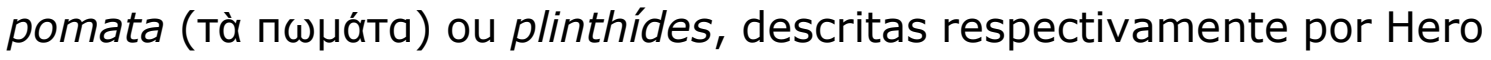
e Vitrúvio (c. Perrot, 1971, p. 109-112). 


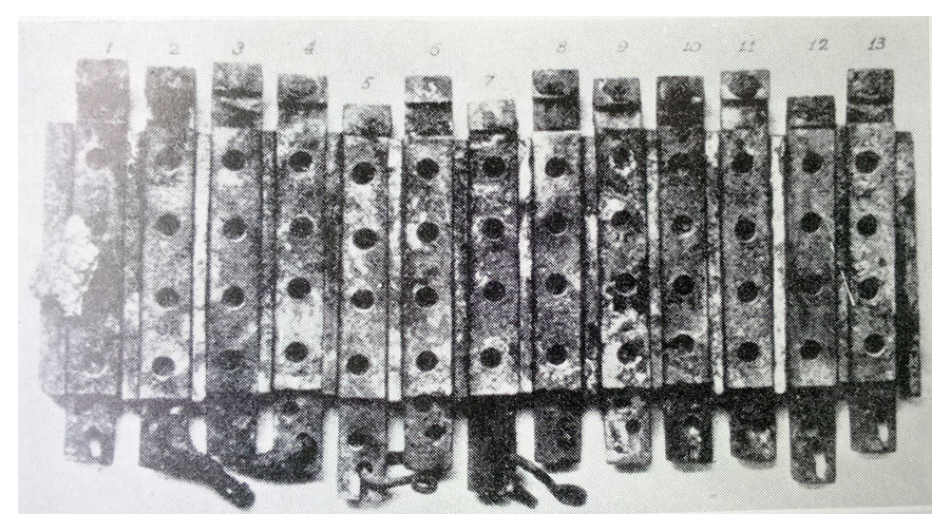

Fig. 107: As plinthídes, teclas deslizantes, do pequeno órgão encontrado em 1931, em Aquincum.

Como já dissemos, com o teclado, a fonte sonora ficou mais distante do músico. A performance musical se transforma e afetará,

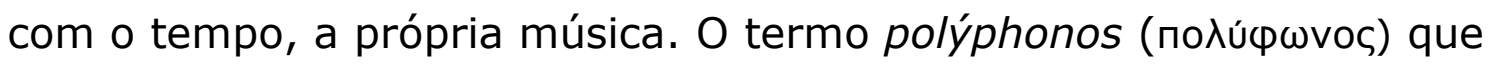
aparece no relato de Pólux sugere um caminho. Se Ptolomeu tivesse a antevisão do pattern geométrico das teclas em duas cores, sua harmônica geométrica seria diferente.

O teclado aparece mais claramente nas iconografias dos séculos XI e XII e ali vemos os músicos utilizando as duas mãos para acionálo, o que nos leva a pensar que ele foi o ingrediente técnico da polifonia. Como declarou Canon Mathias em um congresso de órgão em 1923:

Desde o início, a prática do órgão foi polifônica (...). Além disso, nós precisamos apenas imaginar um ser humano inteligente na frente de tantos tubos, e tantas teclas desobstruindo os tesouros musicais desses tubos. Seria contrário a qualquer razão humana e, no mínimo, ingenuidade, não tentar tocar com as duas mãos simultaneamente, ainda mais que o caminho havia sido preparado já há algum tempo pelas gaitas de fole, que produziam uma verdadeira heterofonia (Mathias, Strasbourg, 1934, p. 166, apud Perrot, 1971, p. 131).

Não se sabe quem teve a ideia de substituir a máquina de produção de ar da hydráulis, trocando os êmbolos por um fole de ferreiro. O regulador de pressão continuou sendo a água, e a cisterna 
e o pnigeus continuaram presentes. De acordo com Perrot, apenas quando foi resolvido o problema da estabilidade do fluxo de ar pelos foles é que a hydráulis pôde ser finalmente substituída (cf. Perrot, 1971, p. 162). A água foi eliminada do sistema e os instrumentos, sem êmbolo e sem cisterna, tornaram-se mais leves e fáceis de ser transportados, sem contar o fato de não apresentarem o grave incômodo de congelar nos países frios.

\subsection{O braço do alaúde}

A pandoura (ท่ navঠooũpa) não é uma criação helenística como a hydráulis; há indícios de sua presença no lado oriental do Mediterrâneo, antes de ela aparecer em textos, figuras e relevos gregos, o que só ocorre efetivamente no período das campanhas persas de Alexandre, em torno de 330 a.C.

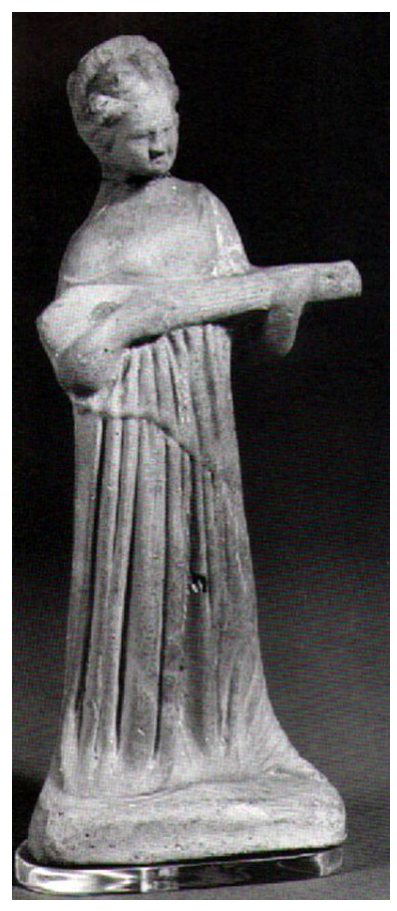

Fig. 108: Terracota mostra mulher com um instrumento de braço no modelo do alaúde (final do século IV a.C.).

A pandoura tinha apenas três cordas, mas podia reproduzir muito mais tons nelas do que qualquer instrumento multicordas. Seu braço longo, trasteado ou não, era também bem mais preciso na localização das notas. Mathiesen nos lembra que "por possuir apenas três cordas, 
[ela] era mais fácil afinar, e sua afinação como um todo seria mais estável" (1999, p.285).

Nicômaco menciona as pandourai descrevendo-as como monocórdios "que os pitagóricos chamam de kánons" (1994, p. 61). Pelo fato de o instrumento ter um braço embaixo das cordas, seria mesmo possível confundi-lo com o kánon e, nesse sentido, é surpreendente que Ptolomeu não tenha abordado o instrumento.

Apesar de ser tocada igualmente com o plectro, a técnica de execução da pandoura distancia-se muito da kithára. No braço da pandoura as notas são produzidas tal como os cavaletes móveis dos kanónes; porém, em seu lugar são os dedos que localizam e pressionam as cordas para produzir as notas, aumentando a sua precisão. Esse é um novo gesto de tocar na cultura musical antiga e produz uma interação ainda maior com o pensamento digital do músico, algo muito próximo do que acontece com o teclado. Essa digitação que produz as notas está presente nas técnicas de execução de sopro, porém no teclado e no braço do instrumento o músico tem a possibilidade de ver as notas como em um kánon ou um diagrama.

Essa morfologia do braço da pandoura será extremamente produtiva no decorrer do desenvolvimento dos instrumentos musicais. Ela está presente nos alaúdes, guitarras, violões e assemelhados, assim como nas famílias das violas e depois dos violinos.

O termo pandoura está relacionado a tanbur, denominação dos instrumentos encontrados hoje em dia no amplo espaço geográfico que vai dos Bálcãs ao Oriente Médio. O tanbur é o instrumento que deu origem ao aláude renascentista. A partir de elementos conhecidos da luteria do alaúde é possível inferir algumas práticas que podem ter frequentado as oficinas antigas.

Sabe-se que, nos países árabes, o tampo do tanbur inicialmente era feito de pele, tal como o tampo da chélys-lyra, mas em algum momento do século VI d.C. ele começou a ser confeccionado meio a meio, a metade de baixo com pele e a metade de cima com madeira 
na qual era feita uma roseta. No início do século VII, o alaúde passou ser produzido inteiramente de pranchas de madeira, em um processo de chapeamento, com duas aberturas acústicas no tampo.

Assim como deve ter acontecido no processo de transformação da lira para a kithára, a principal razão para essa mudança estrutural do alaúde, ou seja, de um tampo de pele para o de madeira, foi de ordem acústica. A modificação fez aumentar o tempo de sustentação das notas, assim como melhorou a audição das notas graves, tornando-o um instrumento mais expressivo (cf. Lundberg, 1992, p. 212).

Nos relevos e terracotas da pandoura, a impressão que temos é de que ela era feita com o tampo de madeira. É possível que mesmo o braço fosse confeccionado em um bloco único, ao qual fosse acoplado posteriormente o tampo, tal como na última etapa da construção da kithára. O pequeno volume de som deve ter sido o motivo pelo qual a pandoura parece ter ficado reservada ao ambiente doméstico e não recebeu muita atenção por parte dos romanos, que gostavam de grandes espetáculos com instrumentos de muito volume.

Apenas a partir da introdução do aláude pelos cruzados na Europa, por volta dos séculos XII e XIII, podemos dizer que a morfologia da pandoura foi retomada no Ocidente. No início do século $X V$, Arnaut de Zwolle nos dá as informações mais antigas sobre o design do alaúde: como construir a forma sobre a qual irá moldar a estrutura para fazer o bojo, utilizando o compasso, onde localizar a roseta, as marcações no braço e onde prender o cavalete na caixa de ressonância (Fig. 109). Como diz Lundberg a respeito das instruções de Zwolle:

Ele nos diz para primeiro desenhar um círculo relativo à parte inferior do corpo do tamanho que desejamos que seja o alaúde e então, abrindo o compasso no diâmetro do círculo que acaba de ser desenhado, desenhar os arcos que se curvam em direção ao braço. Ele 
então recomenda um raio menor para formar o final do braço no corpo. Essa construção produz um croqui que, se o raio final do braço for omitido, é idêntico a muitos aláudes encontrados em fontes visuais do século XV. Nós também notamos que o comprimento do braço desses aláudes frequentemente corresponde às proporções dadas por Arnault. Esses alaúdes de corpo pequeno e arredondado com pescoços compridos são ótimos para tocar linhas melódicas improvisadas, com o plectro, mas mudanças na técnica instrumental impuseram necessidades a esses instrumentos que eles não podiam oferecer (1992, p. 214).

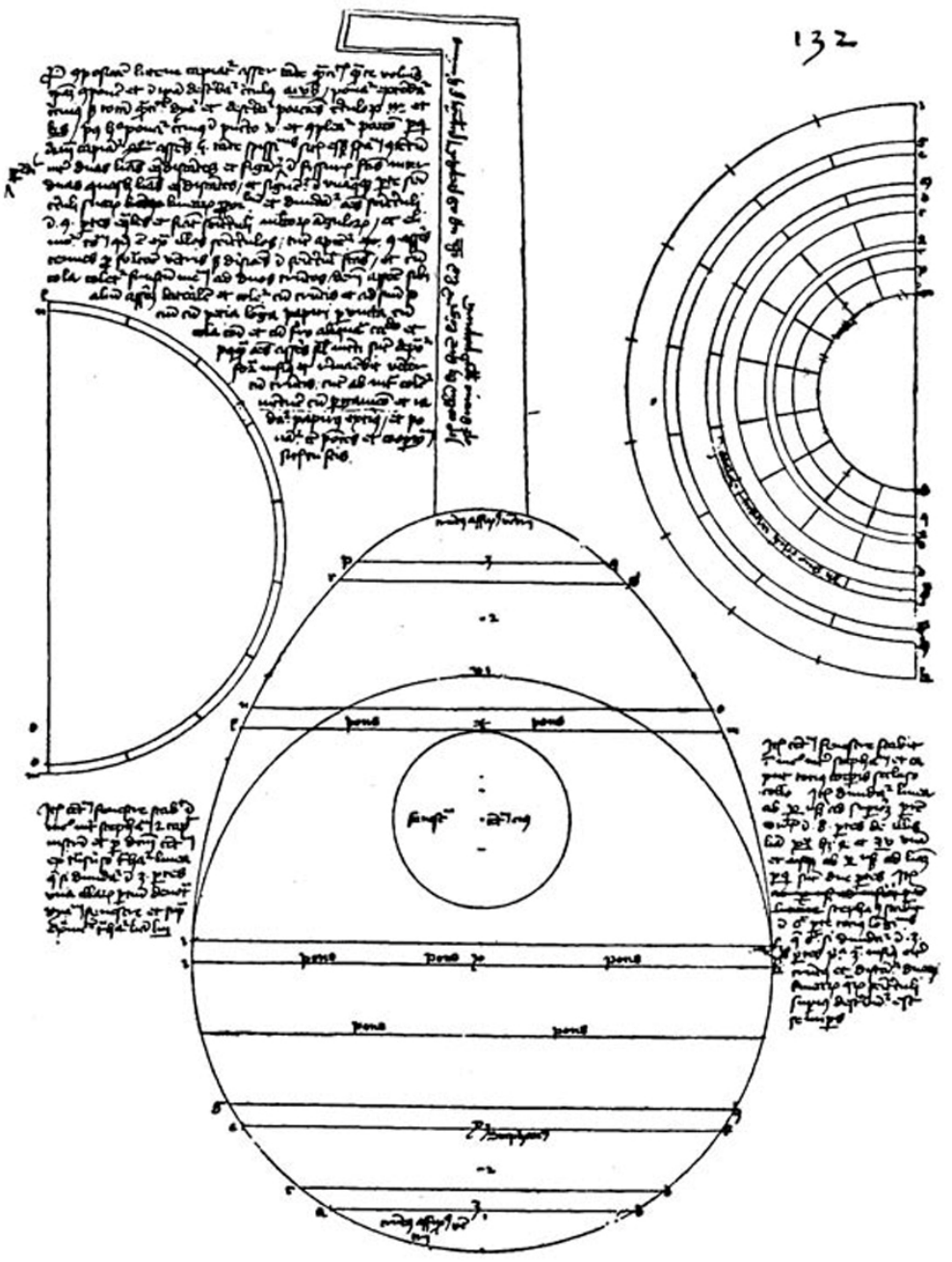

Fig. 109: Diagrama de alaúde do tratado de instrumentos musicais de Arnaut de Zwolle, c. 1450. 
Esse alaúde de Zwolle era tocado com o plectro e ainda estava mais próximo da sonoridade das pandourai gregas, mas na segunda metade do século $X V$, os luthiers alteraram a forma e a estrutura do isntrumento, construindo-o mais compridos com nove ou onze folhas de madeira para o bojo, e muito mais leves. Isso ocorreu devido à necessidade de uma resposta acústica melhor a uma execução sem o plectro. Segundo Lundberg, por volta de 1487, Johannes Tinctoris, em seu tratado De inventione et uso musicae,

fala de uma nova maneira de tocar música polifônica no alaúde na qual, em vez de utilizar um grupo de três ou quatro alaúdes em partes separadas, uma pessoa pode tocar todas as vozes diferentes, mas de maneira homogênea em um único instrumento. Em vez de usar o plectro, passa-se a usar os dedos, mas pelo fato desses alaúdes serem desenhados e construídos para soar com o impacto forte do plectro, eles não respondem bem quando são tocados com a carne macia dos dedos (1992, p. 215).

Mais uma vez é difícil saber se o procedimento técnico fez avançar o campo artístico ou se, vice-versa, a necessidade estética antecedeu a busca por um avanço técnico, ou ainda se foram acontecimentos sincrônicos. No final do século $X V$, apesar de os músicos renascentistas pretenderem voltar o olhar para a música grega, a sua sonoridade já havia sido deixada para trás. O som rascante do plectro é preterido pela suavidade e maciez do alaúde e uma inovação tecnológica, igualmente trazida pelos cruzados, toma corpo na música ocidental: a produção de som pela fricção do arco nas cordas, que não aparece na organologia antiga grega.

Na segunda metade do século XVI, inicia-se a tendência de construir famílias de instrumentos em correspondência às vozes humanas, por exemplo, viola soprano, viola alto, e assim também com as flautas-doce e alaúdes. A aplicação do desenho geométrico ao design dos instrumentos torna-se cada vez mais importante. De acordo 
com Bowles, tornos mais sofisticados, trazidos de Flandres e do sul da Alemanha para a Itália e cruciais para a construção de instrumentos científicos, serão utilizados nas luterias. Além disso,

avanços na manipulação do ferro, que ocorreram entre 1600 e 1700, logo se refletiram em aspectos específicos da construção de instrumentos tais como materiais mais uniformes, entalhes precisos e fabricação de chaves (Bowles, 2012, p. 1).

Nesse ambiente tecnológico renascentista, os instrumentos de performance e de observação terão um papel relevante no quadro da discussão epistemológica musical. A construção do hélicon é mencionada nas Instituições harmônicas de Zarlino, publicada em 1558. O compositor mostra detalhadamente no Livro II, capítulo 24 , a proposição euclidiana da qual deriva a sua construção: Proposição 9 do Livro 6 dos Elementos. No capítulo seguinte, Zarlino oferece outra solução para dividir os intervalos em duas ou mais partes. Aqui ele utiliza o mesolábio, o instrumento inventado por Eratóstenes para encontrar médias proporcionais de maneira mecânica, que mencionamos, e que estava presente nas oficinas de instrumentos de cordas, provavelmente para auxiliar na relação entre as cordas horizontais e os trastes verticais para a afinação dos instrumentos e que mencionara Salinas.

Em 1581, Vincenzo Galilei escreve o Diálogo sobre a música antiga e a moderna em que expõe e compara diversas afinações e defende o temperamento igual. Essa afinação estava presente nas propostas de Aristóxeno, do século IV a.C., mas numa menção muito breve e mesmo assim partindo de uma noção estritamente geométrica. Vincenzo busca princípios a partir da prática real, apesar de sua ciência também valorizar outros aspectos míticos, em especial, a figura de Orfeu. 
Paolo Rossi chama a atenção para a crescente importância, de 1400 a 1770, "do conhecimento técnico e dos processos artificiais pelos quais a natureza era modificada" (Rossi, 1970, p. x). Zarlino e Galilei vivem nesse momento em que há uma comunicação intensa entre os construtores de instrumentos e os músicos. No capítulo 47 das Instituições harmônicas, Zarlino conta que, em 1548, pediu a Domenico da Pesaro (1533-75), famoso construtor de teclados que vivia em Veneza, que construísse um instrumento de 24 teclas para demonstrar as harmonias musicais. De acordo com Meùus (2012, p.1), "esse teclado enarmônico expandia a possibilidade de modulações no temperamento mesotônico, permitia tocar acordes na afinação justa e produzia microtons".

Nicolas Vicentino, aluno de Zarlino, construiu o arquicembalo e discutiu, em seu livro $A$ música antiga reduzida (ridotta) à prática moderna, a dificuldade de combinar os instrumentos de teclados, afinados no temperamento mesotônico, e os trasteados, como as violas de gamba e os aláudes. Assim, o braço da pandoura e o teclado da hydráulis, resultantes de longa acumulação de conhecimento das técnicas de construção e da performance musical finalmente se encontravam e as consequências disso foram cada vez mais criativas na história da música ocidental. 


\section{CONCLUSÃO}

Os instrumentos da oficina de Ptolomeu não foram construídos com o intuito de se tornarem populares no meio musical da época. Aparentemente, seu objetivo era criar instrumentos-diagrama, ou artefatos-modelo, que não funcionavam como instrumentos de performance. De maneira diferente aconteceu com a hydráulis, que igualmente foi criada para ser uma demonstração de princípios de pneumática e transformou-se numa máquina musical de duração milenar.

Nicômaco de Gerasa menciona a hydráulis em seu tratado de harmônica, mas aparenta não ter percebido a dimensão que se abria com o novo instrumento. A hydráulis é elencada como mais um instrumento de sopros de muitos tubos, polykálamos (cf. Nicômaco, 1994, p. 67). Nicômaco é um matemático e a sua harmônica é estritamente aritmética. Quando ele fala de um experimento ocorrido em uma oficina, é possível perceber que ele não os realizou. Do mesmo modo, ao apresentar as relações entre as notas do sistema musical grego e os planetas, seu argumento é de que a localização das notas na escala corresponde à posição dos planetas no céu, um argumento fraco se comparado à ideia de correspondências entre configurações geométricas do movimento dos planetas no céu e configurações geométricas das relações entre as notas tal como desenhados na harmônica ptolomaica. Sem contar que Ptolomeu observou atentamente os astros com instrumentos de medição para isso, certamente o que de mais avançado existia na época.

Mas Ptolomeu, do mesmo modo, não enxergou o futuro promissor da hydráulis. É possível que a visse também apenas como um polykálamos, que utilizava de maneira mais espetacular o pattern da sýrinx. Talvez os matemáticos estivessem evitando encantar-se com as peripécias do ar comprimido e o mecanismo de êmbolos e a cisterna, e podem até mesmo tê-la descartado como se fosse um órgão 
de água, artefato do mesmo período, mas que era realmente um autômato. Depois de colocado em movimento, o órgão de água seguia sem a intervenção humana. Esse autômato vai reaparecer nos escritos árabes medievais e nos jardins renascentistas.

Por outro lado, uma parte da harmônica também foi deixada de lado. Na Idade Média e no Renascimento, os músicos muito estudaram as espinhosas configurações das afinações pitagóricas, aristoxenianas e ptolomaicas e não deram tanta atenção às teorias do conhecimento que as fundamentavam. Os músicos renascentistas tinham uma questão imediata: como combinar alaúdes, violas, teclados e sopros para a prática polifônica.

Certamente houve um problema na recepção da teoria aristoxeniana e dos avanços de Ptolomeu. A força do pitagorismo estava no fato de ele ser um modelo utilizável em várias áreas do conhecimento, enquanto a fraqueza do aristoxenianismo estava justamente na delimitação de seu escopo. Já a teoria da percepção ptolomaica não despertou o interesse de músicos e teóricos naquele momento.

No período medieval, na retomada da herança da música grega por Boécio, o autor romano havia reportado uma opinião errônea de Ptolomeu sobre o tarentino: "Aristóxeno nada credita à razão, mas tudo à sensação" (Institutione Musicae III, p. 355, apud Bélis, 1986a, p. 227 , nota 65 ) e assim transmitiu a ideia de que as duas vertentes foram contrapostas na sua origem, de um lado a racional pitagórica, de outro, a sensorial aristoxeniana.

Mas o núcleo do debate entre as duas correntes nunca havia sido a primazia do intelecto ou da sensação, na medida em que seus objetivos eram diferentes. Por causa disso, muitas confusões se perpetuaram e as teorias se confundiram diversas vezes ao longo da história; por exemplo, a posição "aristóxeno-sensória" foi identificada erroneamente à corrente que defendia os experimentos acústicos. A

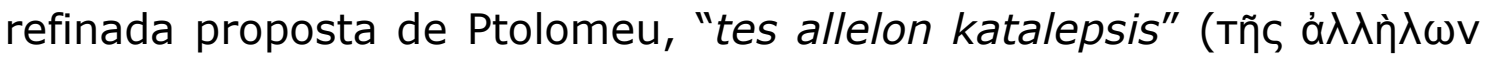


ката $\lambda \dot{\varepsilon} \psi$ Iৎ), das apreensões contrárias, não foi colocada na mesa de discussão.

O tradicional ágon grego, em que os dissensos faziam parte do estilo de apresentação, foi deslocado dos espaços públicos, nos quais todos os cidadãos participavam, substituindo as salutares polarizações por afrontas radicais. Mesmo assim, é interessante perceber que os autores cristãos, ao radicalizarem o caráter enganoso da experiência sensorial, indiretamente, enfatizaram o aspecto determinante da presença do músico na prática de sua arte, como comentam Dahlhaus e Katz:

Enquanto o argumento em favor da razão chama a atenção para a incerteza da experiência sensorial, ele também levanta uma questão a mais, notadamente, que as ilusões relativas à percepção são produzidas por aquele que percebe e residem nele (1989, p. xv).

O rito cristão ocidental começou com o canto no cotidiano das famílias, dentro de suas casas, e foi penetrando nas comunidades até o surgimento dos monastérios. Um pensamento musical mais formalizado surgirá com Ambrósio (340-397), o bispo de Milão. Durante a sua vida houve a cisão da Igreja do Ocidente e do Oriente e a passagem da escrita filosófica do grego para o latim. Há indícios de que tenha sido Ambrósio a introduzir as antífonas nos hinos no Ocidente.

No novo mito, todas as artes corporais, a dança e seus ritmos deveriam ser evitados. O rei Davi toma o lugar de Orfeu, mas raramente é mencionada sua dança ao Senhor. Os anjos podiam dançar, os humanos, não - especialmente os padres, apesar das menções à dança em alguns ritos. O uso litúrgico de instrumentos foi banido por lembrar os pagãos, mas também seguiram sendo usados na música profana, arrefecendo a sua dinâmica de desenvolvimento. A 
Igreja manteve apenas uma ideia herdada dos antigos gregos: a de harmonia universal.

A ideia de que todas as partes do universo estão conectadas harmônica e simpateticamente era um fenômeno facilmente demonstrável nas propriedades de ressonância de instrumentos musicais. No início do século XVII, esse modelo seguirá influente e estará presente nas investigações de Johannes Kepler, mas também sofrerá algumas rupturas com a filosofia de René Descartes. O pensamento cartesiano ecoará, no século XVIII, na teoria musical de Jean-Philippe Rameau que, no entanto, parece retomar a geometria e a astronomia musical de Claudio Ptolomeu, introduzindo a ideia de forças naturais nas relações sistêmicas da linguagem musical. O kanon de Ptolomeu novamente é transformado em círculo nos ajustes de novas afinações.

Assim, não houve na Europa medieval uma continuidade imediata dos avanços que haviam sido feitos na prática de construção de instrumentos na Antiguidade, que, apesar de arrefecerem, não retrocederam. O tanbur seguiu caminho no Oriente e o mesmo podemos dizer do órgão, que foi preservado em Bizâncio e posteriormente investigado em detalhes no mundo árabe.

Quando a polifonia vocal se iniciou no Ocidente, por volta do século IX, curiosamente seu nome será organum. Aos poucos irá ressurgir a importância dos instrumentos para a teoria musical e, a partir do Renascimento, eles estarão envolvidos em questões cruciais para o desenvolvimento da música ocidental, deixando para trás, agora definitivamente, as admoestações de Platão em relação às tentativas de acompanhar a voz com a lira

combinando com pequenos e grandes intervalos, notas rápidas e lentas, agudas e graves, complicando o acompanhamento da lira em todos os sentidos - afetações que deveriam ser banidas de todo 0 repertório da educação musical (812). 
Assim como a hydráulis, a pandoura havia recebido pouca atenção dos teóricos do período helenístico tardio, mas ambos terão um pattern de linhagem duradoura na música ocidental.

Popper registrou seu espanto com a polifonia em sua Autobiografia intelectual:

A polifonia, como a ciência, é peculiar à civilização ocidental. (Estou empregando o termo "polifonia" para denotar não apenas o contraponto, mas também a harmonia musical própria do Ocidente). Diversamente da ciência, a polifonia não parece ter tido origem grega, surgindo entre os séculos IX e XV da nossa era. Se assim é, tratar-seá, possivelmente, de uma realização sem raízes anteriores, a mais original e, na verdade, a mais miraculosa da civilização ocidental, sem excluir a ciência (Popper, 1977, p. 62).

Contudo, nosso estudo aponta para outras direções em relação à origem da música polifônica, remetendo-a aos gestos técnicos gerados a partir de dois artefatos musicais em especial: o teclado do órgão e o braço do alaúde. A construção teórica monumental do contraponto e depois da harmonia teve, assim, sua possibilidade instrumental para além das vozes.

Se assim for, a polifonia como técnica de composição foi gestada nas congruências e intersecções entre Ocidente e Oriente. Lloyd nos mostra como a ideia de uma ciência exclusivamente ocidental se desmoronou nas últimas décadas:

Como um corolário, a ciência natural moderna não é uma descendente unilinear da filosofia natural grega. Esse mito evaporou há muito tempo atrás quando os historiadores se deram conta de compreender os contextos da investigação. Em vez disso, eles traçaram a ancestralidade das especialidades modernas até a mistura cosmopolita que formou o mundo muçulmano das tradições siríaca, persa, do antigo 
Oriente Médio, Índia, Leste da Ásia e tradições greco-romanas. Essa mistura penetrou a Europa no começo do ano 1000, trazendo muitos componentes poderosos a respeito dos quais os gregos nunca sonharam. Isso estimulou a mudança que se acelerou até os dias de hoje (Lloyd, 2002, p. xiii).

Com a música ocidental ocorre o mesmo. Muito se pode dizer acerca da entrada dos refinados instrumentos orientais na Europa trazidos pelos cruzados. O mundo islâmico dos séculos VIII a $X$ foi bastante produtivo no campo do conhecimento e sabe-se que, assim como o alaúde, o órgão no mundo árabe foi estudado do ponto de vista técnico e mecânico (cf. Perrot, 1971, p. 185).

Sendo assim, a técnica da polifonia seria anterior à sua ciência. Mas o que podemos afirmar de fato é que, se o design do aláude foi criado anonimamente em algum canto do lado oriental do Mediterrâneo, a hydráulis helenística tem endereço certo de nascimento: a casa de Ctesibius e Taïs em Alexandria, em um tempo e um lugar em que foi combinada a admiração pelos encantos da música e da técnica. 


\section{REFERÊNCIAS BIBLIOGRÁfICAS}

AmZALAK, M.B. Hesíodo e o seu poema "Os trabalhos e os dias".

Lisboa: Academia das Ciências de Lisboa, 1947.

ANDERSON, W. Music and musicians in ancient Greece. Ítaca/Londres:

Cornell University Press, 1994.

ARIStóteles. Metafísica. Tradução: V. Cocco. São Paulo: Abril Cultural, 1979. (Coleção Os Pensadores).

. Metafísica. Disponível em: <data.perseus.org /catalog/ urn:cts:greekLit:tlg0086.tlg025> Acesso em: 1 maio 2015.

Medford: Tufts University/Leipzig: The University of Leipzig, 2015.

. Physics. Books I-IV. Tradução: P.H. Wicksteed \& F.M.

Cornford. GooLD, G.P. (Ed.) Cambridge: Harvard University

Press, 1996. (Loeb Classical Library).

. Physique (V-VIII). Tradução: Henri Carteron. Paris: Les Belles Lettres, 1961.

. Poétique. Tradução: J. Hardy. Paris: Les Belles Lettres, 1995.

. Politics. Tradução: H. Rackam. Henderson, J. (Ed.).

Cambridge: Harvard University Press, 2005. (Loeb Classical Library, v. 21).

. Posterior Analytics. In: ACKRILL, J.L. (Ed.) A new Aristotle

reader. Oxford: Clarendon Press, 1987, p. 39-59.

. Segundos Analíticos. Livro II. Tradução: L. Angioni. Cadernos

de Tradução, 4. Campinas: IFCH/UNICAMP, 2002. (Clássicos da Filosofia).

ARISTóxeNo. Elementa harmonica. In: Rios, R. DA (Ed.) L'armonica.

Roma: Typis Publicae Officinae Polygraphicae, 1954.

. The harmonics. In: MACRAN, H. (Ed.) The harmonics of

Aristoxenus. Hildesheim/New York: Georg Olms, 1974. 
ARQUITAS. Fragmentos. Tradução: I.L. Borges. São Paulo: Abril Cultural, 1973, p. 260-1. (Coleção Os Pensadores).

Ateneu. Deipnosophistae. In: Greek musical writings. Cambridge/New York: Cambridge University Press, 1989a. v.1, The musician and his art. p. 258-303

BACON, F. La sagesse des anciens. Paris: Vrin, 1997.

BaILly, A. Dictionnaire grec-français. Paris: Hachette, 1963.

BARBERA, A. The Euclidean Division of the canon - Greek and Latin sources. Lincoln/London: University of Nebraska Press, 1991.

BARBour, J. M. Tuning and temperament. A historical survey. Mineola/New York: Dover Publications, 2004.

BARKER, A. Greek musical writings. Cambridge/New York: Cambridge University Press, 1989. 2v. . Greek musical writings. Cambridge/New York: Cambridge University Press, 1989a. v.1, The musician and his art. . Greek musical writings. Cambridge/New York: Cambridge University Press, 1989b. v.2, Harmonic and acoustic theory. . Scientific method in Ptolemy's harmonics. New York: Cambridge University Press, 2000. . The science of harmonics in Classical Greece. New York: Cambridge University Press, 2007.

BÉLIS, A. À propos de la construction de la lyre. Bulletin de correspondence hellénique, v.109, 1985. p. 201-20. Disponível em <www. persee.fr/web/ revues/home /prescript/ article/ bch_0007-4217_1985_num_109_1_1823>.1985. p. 201-220. Acesso em: 20 abr 2015. . Aristoxène de Tarente et Aristote: Le traité d'harmonique. Paris: Klincksieck, 1986a. 
. Aulos. Grove Music Online. Oxford Music Online. Root, D.

(Ed.) Oxford University Press. Disponível em <www.

oxfordmusiconline.com/subscriber/article/grove/music/01532>. Acesso em: 13 mar 2015

. De l'image à l'instrument; reconstruction de la grande cithare grecque. Revue Archéologique, 1. Paris: Presses Universitaires de France, 2000. p. 203-207.

. Kroupezai, scabellum. Bulletin de correspondence hellénique, v.111, 1988a. p. 323-39. Disponível em www.persee.fr/ web/ revues/ home/prescript/article/bch_00074217_1988_num_112_1_1748. Acesso em: 22 mar 2015. . L'aulos phrygien. Revue Archéologique, 1. Paris: Presses Universitaires de France, 1986b. pp. 21-40. . La phorbéia. Bulletin de Correspondance Hellénique v. 110, 1986c. p. 203-218.

. Les fabriquants d'auloi en Grèce - L'exemple de Délos. Tópoi, v. $8 / 2$, 1998. p.777-790. . Les musiciens dans l'Antiquité. Paris: Hachette, 1999. . Les termes grecs et latins désignant des spécialités musicales. Revue de Philologie, de Littérature et d'Histoires Anciennes, v. 62, 1988b. p. 227-50.

. Un nouveau document musical. Bulletin de Correspondance Hellénique v. 108, 1984. pp. 99-109.

BERRYMAN, S. Ancient automata and mechanical explanation. Phronesis, 48/4. Leiden: Koninklijke Brill NV, 2003. . The mechanical hypothesis in ancient greek natural philosophy. New York: Cambridge University Press, 2009. BlAKELY, Sandra. Myth, ritual, and metallurgy in Ancient Greece and Recent Africa. New York: Cambridge University Press, 2006. 
Bouillot, P. \& Chatellard, X. Les rabots. Turin, Editions Vial, 2010.

BowLES, E.A. Instruments and technology. Root, D. (Ed.) Oxford University Press. Disponível em <www. oxfordmusiconline. com/subscriber/article/grove/music/49848 > Acesso em: 14 out 2012.

BundRICK, S. Music and image in Classical Athens. New York: Cambridge University Press, 2005.

BURFORD, A. Craftsmen in greek and roman society. London: Thames and Hudson, 1972.

BURY, R.G. Plato in twelve volumes, v.9. Cambridge/London: Harvard University Press, 1989. (Loeb Classical Library)

CAMPBeLL, D. M. ET AL. Musical instruments, history, technology and performance of instruments of Western music. New York: Oxford University Press, 2004.

CASSOLA, F. (Ed.). Inni omerici. Rocca San Casciano: Mondadori, 1997.

Cerqueira, F. V. Os instrumentos musicais na vida diária da Atenas tardo-arcaica e clássica (550-400 a.C.). O testemunho de vasos áticos e textos antigos. Tese de doutorado, FFLCH/USP, 2001.

Ceulemans, A. De la vièle médiévale au violon du XVII ème siècle. Étude terminologique, iconographique et theorique. Turnhout: Brepols Publishers, 2011.

ComotTI, G. Music in greek and roman culture. Baltimore/London: The John Hopkins University Press, 1989.

CREESE, D. Instruments and Empiricism in Aristoxenus' Elementa Harmonica" In: Aristoxenus of Tarentum. Huffman, C.A. (Ed.) New Jersey: Transaction Publishers, 2012. p. 29-64. . The monochord in ancient greek harmonic science. Cambridge: Cambridge University Press, 2010. 
. The origin of the greek tortoise-shell lyre. Halifax: Dalhousie University, 1997.

CROCKER, R. L. Aristoxenus and the greek mathematics. In: Aspects of medieval and renaissance music - a birthday offering to Gustave Reese. LA RUE, J. (Ed.). New York: W.W. Norton \& Company Inc., 1966. p. 96-110.

CRombie, A.C. Science, optics and music in medieval and early modern thought. London: The Hambledon Press, 1990.

Dahlhaus, C. \& Katz, R. Contemplating music, V. 1. New York: Pendragon Press, 1987. . Contemplating music, V. 2. New York: Pendragon Press, 1989.

Donini, P. The history of the concept of eclecticism. In: DilLon, J. \& Long A. A. (ED.). The question of "eclecticism". Berkeley/Los Angeles: University of California Press, 1996. p. 15-33.

DUBORD, C. Histoire de l'outillage des métiers connexes de l'ébénisterie. Disponível em <www.iqe.edu/ Histoire_ outillage_metiers_connexes_2.php> Acesso em: 7 fev 2014.

DUSCHESNES, J.\& GUILLEMIN, M. Sur l'origine asiatique de la cithare grecque. L'antiquité classique, v. 4, fasc. 1, 1935. p. 117-124.

ERRANDONEa P. Ignacio. Diccionario del mundo clásico. Barcelona: Editorial Labor, 1957.

Ésquito. Prometeu Agrilhoado. Tradução: Fernando Melro. Lisboa: Inquérito, 1984.

Evelyn-White, H G. Hesiod, The homeric hymns, Epic cycle, Homerica. Cambridge, Massachusetts: Harvard University Press. (Loeb Classical Library V.57), s.d.

Everson, S. Epistemology. Cambridge: Cambridge University Press, 1990. (Companions to ancient thought v.1) 
Filolau. Sobre a natureza. Tradução: I.L. Borges. São Paulo: Abril Cultural, 1973, p. 255-58. (Coleção Os Pensadores).

Finley, M. I. Grécia Primitiva: Idade do Bronze e Idade Arcaica. São Paulo: Martins Fontes, 1990.

GAGNEBIN, J.M. Sete aulas sobre linguagem, memória e história. São Paulo: Imago, 1997.

GiBSON, S. Aristoxenus of Tarentum and the birth of musicology. New York: Routledge, 2005.

Gramani, J.E.\& D. Rabeca, o som inesperado. Curitiba: Fundação Cultural de Curitiba, 2002.

Gusmão, C. A harmônica na Antiguidade grega, São Paulo, 2010. Diss. Mestrado, FFFLCH/USP.

Hallyn, F. La structure poétique du monde: Copernic, Kepler. Paris: Éditions du Seuil, 1987.

Havelock, E. A revolução da escrita na Grécia. São Paulo: Unesp/Paz e Terra, 1994.

HEATH, T. A history of greek mathematics. Oxford, Clarendon Press, 1981.

Heráclito. Fragmentos. Tradução: José Cavalcante de Souza. São Paulo: Abril Cultural, 1973, p. 79-97. (Coleção Os Pensadores).

Hero de Alexandria. Pneumaticas. London: MacDonald/New York: American Elsevier, 1971.

Heródoto. História. Brasília: Editora Universidade de Brasília, 1985.

Hesíodo. Os trabalhos e os dias. In: Amzalak, M.B. Hesíodo e o seu poema "Os trabalhos e os dias". Lisboa: Academia das Ciências de Lisboa, 1947. . Os trabalhos e os dias. Tradução: M. Lafer. São Paulo: Iluminuras, 1996. 
. Teogonia. In: Torrano, J. Teogonia de Hesíodo. Origem dos deuses. São Paulo: Iluminuras, 1995.

Homero. Ilíada. Tradução: Carlos Alberto Nunes. São Paulo: Ediouro, s.d. . Odissea. Tradução: R.C. Onesti. Torino: Einaudi, 1989. . Odisseia. Tradução: Jaime Bruna. São Paulo: Cultrix, 1997.

Huffman, C. A. Archytas of Tarentum. Pythagorean, philosopher and mathematician king. Cambridge/New York: Cambridge University Press, 2010.

KURFÜRST, P. The ancient greek kithára. Studia minora Facultatis Philosophicae Universitatis Brunensis, v. 25, 1992. p. 7-13.

LANDELS, J. G. Music in ancient Greece and Rome. New York: Routledge, 2000.

LEFTWICH, G. Polikleitos and hippocratic medicine. In: Polykleitos, the Doriphoros and the tradition. Moon, W.G. (Ed.) Madison: The University of Wisconsin Press, 1985. p. 38-51.

LÉvi-Strauss, C. La pensée sauvage. Paris: Plon, 1962.

LLOYD, G.E.R. Greek science after Aristotle. New York/London: W.W. Norton Company, 1973. . Magic, reason and experience. Studies in the origins and development of greek science. Cambridge: Cambridge University Press, 1979. . Methods and problems in greek science. Cambridge: Cambridge University Press, 1991. .Polarity and Analogy. Cambridge: Cambridge University Press, 1971. 
. The revolutions of wisdom - studies in the claims and practice of ancient Greek science. Berkeley: University of California Press, 1987. .The way and the word. Science and medicine in early China and Greece. New Haven/London: Yale University Press, 2002.

Long A. A. Ptolemy on the criterion: an epistemology for the practicising scientist. In: DilLon, J. \& LoNG A. A. (ED.). The question of "eclecticism". Berkeley/Los Angeles: University of California Press, 1996. p.176-207.

LUNDBERG, R. "In tune with the universe: the physics and metaphysics of Galileo's lute". In: Music and Science in the age of Galileo. CoelHo, V. (Ed.) Dordrecht: Kluwer Academic Publishers, 1972.

MAAS, M. \& SNYDER, J.M. Stringed instruments in ancient Greece. New Haven/London: Yale University Press, 1989.

MACRAN, H. (Ed.) The harmonics of Aristoxenus. Hildesheim/New York: Georg Olms, 1974.

Mathiesen, T. Apollo's lyre. Nebraska: University of Nebraska Press, 1999.

Mauss, M. As técnicas do corpo. In: Sociologia e Antropologia. São Paulo: Cosac Naify, 2008. p. 399-422.

Mckinnon, J.W. Hydráulis. Grove Music Online. Oxford Music Online. Root, D. (Ed.) Oxford University Press. Disponível em <www.oxfordmusiconline.com/subscriber/article/ grove/music/13639> Acesso em: 6 mar 2013.

Mersenne, M. "Traité des instruments: Livre Premier, Livre Second". In: Harmonie Universelle. Paris: Éditions du Centre National de La Recherche Scientifique, 1986. 
Meùus, N. Keyboard. Grove Music Online. Oxford Music Online. $<$ www.oxfordmusiconline.com/subscriber/article/grove/music/1 4944> Acesso em: 6 abril 2015.

NicômACO DE GERASA. The manual of harmonics. Tradução: Flora Levin Grand Rapids: Phanes Press, 1994.

Olesko, K. M. "Aesthetic Precision". In: Tensions and convergences. Technological and aesthetic transformations of society. HEIL, R., Kaminsky, A.; Stippak, M. ;Unger, A.; Ziegler, M. (Ed.) New Brunswick/London: Transaction Publishers, 2007. p. 37-46.

PARRY, M. "The traditional epithet in Homer" In: The making of homeric verse. The collected papers of Milman Parry. New York: Oxford University Press, 1971. p. 1-23.

Paton, W. R. The Greek Anthology. V. 4 London: William Heinemann Ltd.,1916.

Penedo, T.DE B. Mundo vegetal e narrativa simbólica em As Bacantes de Eurípides. Disponível em: <lisboa.academia. edu/ TiagoPenedo/Papers>. Acesso em: 18 out 2014.

PERROT, J. The organ from its invention to the end of the thirteenth century. London: Oxford University Press, 1971.

PlatÃo. Critias. Tradução: Bury, R.G. (Ed.) Plato in twelve volumes, v.9. Cambridge/London: Harvard University Press, 1989a. (Loeb Classical Library). .Eutidemo. Disponível em <urn:cts:greekLit:tlg0059.tlg021> Acesso em: 1 maio 2015. Medford: Tufts University/Leipzig:The University of Leipzig, 2015. . Fédon. In: Diálogos 2. Tradução: Paleikat, J. Rio de Janeiro: Ediouro, s.d. 
. Fedro. In: Plato. Platonis Opera. Burnet, J. (Ed.) Oxford University Press. 1903. Disponível em <urn:cts: greek Lit:tlg0059.tlg012 > Acesso em: 2 maio 2015. . Laws. Disponível em <urn:cts:greekLit: tlg0059. tlg034. perseus-eng1> Tradução: Bury, R. G. Acesso em: 1 maio 2015. Medford: Tufts University/Leipzig:The University of Leipzig, 2015. . Laws. Disponível em <urn:cts:greekLit:tlg0059.tlg034> Acesso em: 1 maio 2015. Medford: Tufts University/Leipzig:The University of Leipzig, 2015. . La Repubblica. Lozza, G. (Ed.) Milão: Mondadori, 2006. . Phaedo. Disponível em <urn:cts:greekLit:tlg0059.tlg004> Acesso em: 1 maio 2015. Medford: Tufts University/Leipzig:The University of Leipzig, 2015. . Político. Disponível em:<urn:cts:greekLit:tlg0059.tlg008> Acesso em: 2 maior 2015. Medford: Tufts University/ Leipzig:The University of Leipzig, 2015. . Protagora. Dorati, M. (Ed.) Milão: Oscar Mondadori, 2000. . Timaeus. In: Bury, R.G. Plato in twelve volumes. Cambridge/London: Harvard University Press, 1989. (Loeb Classical Library. V. 9).

Plinio. The natural history. Bostock, J. Riley, H.T. (Ed.) London: . Taylor and Francis, 1855. Disponível em:<data.perseus.org /catalog/urn:cts:latinLit:phi0978> Acesso em: 1 maio 2015 POPPER, K. Autobiografia intelectual. São Paulo: Cultrix, 1986. PRICE, M. The statue of Zeus at Olympia. In: The Seven Wonders of Ancient World. London: Routledge, 2002. p. 59-77. 
Pseudo-Aristóteles. De Audibilibus. In: Greek musical writings.

Cambridge/New York: Cambridge University Press, 1989b. v.2, Harmonic and acoustic theory.

Pseudo-EuClides. Division of the canon. In: The Euclidean Division of the canon - Greek and Latin sources. Lincoln/London: University of Nebraska Press, 1991.

Ptolomeu, C. Harmonics. In: Solomon, J. Ptolemy Harmonics. London: Brill, 2000. . Las hipótesis de los planetas. Tradução: J.G.Blanco e A.C. Ledesma. Madrid: Alianza Editorial, 1987. - Harmonica. In: Raffa, M. La scienza armonica di Claudio Tolemeo. Messina: Edizioni Dr. Antonio Sfamini, 2002.

PSEUDO-ARISTÓTELES De audibilibus. In: Greek musical writings. Cambridge/New York: Cambridge University Press, 1989b. v.2, Harmonic and acoustic theory. p.98-109. . Problemas musicais. In: Aristóteles - Problemas musicais.

Tradução: M. L. Roque. Brasília: Thesaurus Editora, 2001. Pseudo-Euclides. The Division of the Canon. In: Barbera, A. The Euclidean Division of the canon - Greek and latin sources. Lincoln/London: University of Nebraska Press, 1991.

Raffa, M. La scienza harmonica. Messina: Edizioni Dr. Antonio Sfamini, 2002.

Rios, R. DA L'armonica. Roma: Typis Publicae Officinae Polygraphicae, 1954.

Ribeiro JR., W. A. Hinos homéricos. São Paulo: Editora Unesp, 2010.

RocCONI, E. "Aristoxenus and musical ethos". In: Aristoxenus of Tarentum. In: Aristoxenus of Tarentum. HuffmAn, C.A. (Ed.)

New Jersey: Transaction Publishers, 2012. p. 65-90. 
Roque, M. L. Aristóteles - Problemas musicais. Brasília: Thesaurus Editora, 2001.

Rossi, P. Philosophy, technology and the arts in the early modern era. New York: Harper Torchbooks, 1970.

SCHULER, S. Homer and handtools: a woodworking Odyssey.

Disponível em: <literaryworkshop.wordpress.com/2010/ 12/31/>. Acesso em: 20 abril 2015.

SCHUELLER, H. Idea of Music: an introduction to musical aesthetics in Antiquity and the Middle Ages. Kalamazoo: Medieval Institute Publications, 1988.

Sedeño, E. P. Introducción. In: Las hipótesis de los planetas.

Tradução: José Garcia Blanco e Aurora Cano Ledesma. Madrid: Alianza Editorial, 1987. p. 9-51.

Solomon, J. Ptolemy Harmonics. London: Brill, 2000.

SzABó, A. Les débuts des mathématiques grecques. Paris: Librairie Philosophique J. Vrin, 1977.

TEOFRASTO. Enquiry into plants. Londres: William Heinemann \& Nova York: G.P. Putnam's sons, 1916.

TomLinson, G. Music in Renaissance magic. Chicago, The University of Chicago Press, 1993.

Torrano, J. Teogonia de Hesíodo. Origem dos deuses. São Paulo: Iluminuras, 1995.

Treitler, L. (Ed.) Strunk's Source Reading in Music History. New York: Norton Company, 1998.

Tucídides. História da guerra do Peloponeso. Tradução: M. da G. Cury. Brasília: Editora Universidade de Brasília, 1987.

VALERY, P. "La conquête de la ubiquité". In: Fuvres. Paris : Gallimard, 1993. p.1284-5. 
Van Wymeersch, B. Descartes et l'evolution de l'esthétique musicale. Sprimont: Pierre Mardaga Editeur, 1999.

VernANT, J. Mito e pensamento entre os gregos. São Paulo: Edusp, 1973.

VidAL-NAQUET, P. Le chausseur noir. Formes de pensée et formes de societé dans le monde grec. Paris: François Maspero, 1981. . O mundo de Homero. São Paulo: Companhia das Letras, 2002.

WACHSMANN, K. \& KARTOMI, M. J. Scope of the study of instruments as objects and as aspects of biological and social musical activity. Grove Music Online. Oxford Music Online. Root, D. (Ed.) Oxford University Press. Disponível em <www. oxfordmusiconline. com / subscriber/article/img/grove/music/F003009>. Acesso em: 7 abr 2015.

WAIZBORT, L. Max Weber. Fundamentos racionais e sociológicos da música. São Paulo: Edusp, 1995.

WEBER, M. Fundamentos racionais e sociológicos da música. In: WAIZBORT, L. Max Weber. Fundamentos racionais e sociológicos da música. Tradução: L. WAIZBORT. São Paulo: Edusp, 1995.

West, M.L. Ancient greek music. New York: Oxford University Press, 2005.

Williams, P. A new history of the organ. From the Greeks to the present day. London: Faber and Faber, 1980.

WiLSON. P. Music. In: A companion to greek tragedy. GREGORY, J. (Ed.). Maldem/Oxford: Blackwell Publishing, 2008.

XANTHOULIS, N. The salpinx in greek antiquity. International Trumpet Guild Journal, 2006. p. 39-45.

Xenofonte. Memorabilia. Marchant, E. C. (Ed.). Xenophon in Seven Volumes, 4. E. C. Marchant. Cambridge: Harvard University 
Press/ Londom:William Heinemann, 1923. Disponível em:

<urn:cts:greekLit:tlg0032.tlg002> Acesso em: 10 mar 2015.

ZARLINO, G. Le istitutioni harmoniche. Disponível em: <digital. library.unt.edu/ark:/67531/metadc25955/> Acesso em: 13 out 2012. 


\section{REFERÊNCIAS ICONOGRÁFICAS}

\section{Capítulo 1}

Fig. 1: Coleção Museu Arqueológico Nacional de Atenas.

Fig. 2: Coleção Museu Arqueológico Nacional de Atenas.

Fig. 3: Coleção Museu Arqueológico Nacional de Atenas.

Fig. 4: Coleção Museu Arqueológico Nacional de Atenas.

Fig. 5: Sarcófago de Hagia Tríada, sítio de Knossos, ilha de Creta, Grécia.

Fig. 6: Sarcófago de Hagia Tríada, sítio de Knossos, ilha de Creta, Grécia.

Fig. 7: Palácios de Pylos, Messênia, Grécia.

Fig. 8: Coleção Museu Arqueológico Nacional de Atenas.

Fig. 9: Reprodução de Journal of Hellenic Studies, n. 30 (Maas \& Snyder, 1989, p.17).

Fig.10: Reprodução de L'Antiquité classique, v. 4 (Maas \& Snyder, 1989, p. 18).

Fig.11: Coleção Antikensammlungen, Munich.

Fig. 12: Reprodução de Guide to Cretan Antiquities (Maas \& Snyder, 1989, p.20).

Fig.13: Coleção Museu Arqueológico Nacional de Atenas.

\section{Capítulo 2}

Fig. 14: Coleção Fine Arts Museum, Boston.

Fig. 15: Coleção Antikensammlungen, Munich.

Fig.16: Arquivos da BBC de Londres.

Fig. 17: Ilustração de Jones, G.D: Burford, 1972, p. 83.

Fig. 18: Coleção British Museum, London (Burford, 1972, fig. 14).

Fig. 19: Coleção Museu de Berlim (Oriental) (Burford, 1972, fig. 18).

Fig. 20: Coleção British Museum, London (Burford, 1972, fig. 6).

Fig. 21: Coleção Acropolis Museum, Atenas (Burford, 1972, fig. 19).

Fig. 22: Coleção Erich Lessing/AKG Paris (Vidal Naquet, 2000, fig. 9). 
Fig. 23: Coleção Beazley 303253, Londres, British Museum.

Fig. 24: Coleção Antikenmuseum, Basel.

Fig. 25: referência não disponível.

Fig. 26: Coleção Museu do Louvre.

\section{Capítulo 3}

Fig. 27: Coleção Antikennmusem, Munich.

Fig. 28: Coleção Museu Nacional Arqueológico de Atenas (Maas \& Snyder, 1989, p. 42).

Fig. 29: Reprodução de Die Kunst Anatoliens, p. 15 (Maas \& Snyder, 1989, p. 42).

Fig. 30: Coleção American School of Classic Studies at Athens, Agora Excavations (Maas \& Snyder, 1989, p. 43).

Fig. 31: Reprodução de The Sanctuary of Artemis Orthia, fig.180 e 183 (Maas \& Snyder, 1989, p. 48).

Fig. 32: Coleção Museu Arqueológico de Plovdiv, Bulgária (Cerqueira, 2001 , v. 2, p. 569).

Fig. 33: Foto de Winfried Bruenken, Wikimedia Commons. Oryx gazelle. Disponível em: <commons.wikimedia.org/wiki/

File:Spie\%C3\%9Fbock_(Oryx_gazella)_PICT0621.JPG\#mediaviewer> Acesso em: 15 jan 2015.

Fig. 34: Coleção Museu Arqueológico de Delfos.

Fig. 35: Coleção Madison, Universidade de Wisconsin, Elvehjem Museum.

Fig. 36: referência não disponível.

Fig. 37: Coleção Ella Riegel Memorial Museum (Cerqueira, 2001, v. 2, p. 501).

Fig. 38: Coleção New York Metropolitan Museum (Maas \& Snyder, 1989, p. 50).

Fig.39: Reprodução de Curtius/Adler/Treu, Ergebnisse der Ausgrabungen Olympia (Maas \& Snyder, 1989, p. 45).

Fig. 40: Coleção Beazley. 
Fig. 41: Burford, 1972, fig. 47.

Fig. 42: Coleção Museu do Louvre (apud Burford, 1972, fig. 8).

Fig. 43: Coleção New York Metropolitan Museum (Bundrick, 2005, p. 30).

Fig. 44: Burford, 1972, f. 12.

Fig. 45: Coleção Museu Nacional de Copenhaguen (Burford, 1972, fig. 11).

Fig. 46: Coleção Antikensammlungen, Munich.

Fig. 47: Coleção New York Metropolitan Museum.

Fig. 48: Coleção Solow Art and Architecture Foundation, New York.

Fig. 49: Coleção Fine Arts Museum, Boston.

Fig. 50: Coleção Staatliche Antikensammlung, Munich.

Fig. 51: Coleção Antikensammlungen, Munich (Burford, 1972, fig. 17).

Fig. 52: Coleção Museu de Olympia (Burford, 1972, fig. 32).

Fig. 53: Coleção Fine Arts Museum, Boston.

Fig. 54: Burford, 1972, fig. 69.

Fig. 55: Coleção Beazley 201642, London, British Museum.

Fig. 56: Coleção Antikensammlung, Berlim.

Fig. 57: Disponível em: <http://en.wikipedia.org/wiki/Seikilos_ epitaph>. Acesso em: 1 maio 2015.

Fig. 58: sem referência disponível.

Fig. 59: Coleção: Museu Nacional Arqueológico de Atenas.

Fig. 60: Coleção: Beazley 214557, Rijksmuseum van Oudheden, Leiden.

Fig. 61: Coleção Museu Arqueológico Nacional de Atenas.

Fig. 62: Coleção Museu Cívico de Bolonha.

Fig. 63: Coleção Beazley 201955 Basel, Antikenmuseum und Sammlung Ludwig: KA422.

Fig. 64: Coleção Museu do Louvre, Paris.

Fig. 65: sem referência disponível.

Fig. 66: Coleção British Museum, London. 
Fig. 67: Coleção Fitzwilliam Museum, Cambridge.

Fig. 68: Coleção Museu Arqueológico Nacional de Atenas.

Fig. 69: Coleção Museu Capitolino, Roma.

Fig. 70: Coleção Museu dos Ofícios, Florença.

Fig. 71: sem referência disponível.

Fig. 72: Coleção Beazley 216188; Oxford, Ashmolean Museum.

Fig. 73: Coleção London, 271.

Fig. 74: Coleção New York Metropolitan Museum.

Fig. 75: Coleção Museu Nacional Arqueológico de Tarento, Itália.

Fig. 76: Coleção Antikenmuseum, Munich.

\section{Capítulo 4}

Fig. 77: Coleção Museu Arqueológico de Elêusis.

Fig. 78: Desenho geométrico.

Fig. 79: Coleção Ashmolean Museum, Oxford.

Fig. 80: Coleção Staatliches Museum Schwerin (Bundrick, 2005, p. 71).

\section{Capítulo 5}

Fig. 81: Pneumaticas de Hero de Alexandria, prancha 57.

Fig. 82: Prancha 44 das Pneumaticas de Hero de Alexandria.

Fig.83: Prancha 49 das Pneumaticas de Hero de Alexandria.

Fig. 84: Prancha 77 das Pneumaticas de Hero de Alexandria.

Fig. 85: Prancha 76 das Pneumaticas de Hero de Alexandria.

Fig. 86: Perrot, 1971, plate xxiii.

Fig. 87: Perrot, 1971, p. 29.

Fig. 88: Mackinnon, 2015, p. 2.

Fig. 89: Perrot, 1971, p. 37.

Fig. 90: Perrot, Plate xxiv.

Fig. 91: Perrot, 1971, Plate ii.

Fig. 92: Perrot, 1971, Plate i.

Fig. 93: Perrot, 1971, Plate xxv. 


\section{Capítulo 6}

Fig. 94: Theorica musicae de Franchino Gaffurio, 1492.

Fig. 95: Creese, 2010, p. 307.

Fig. 96: Creese, 2010, p. 313.

Fig. 97 a 102: Formações do hélicon.

Fig. 103: Creese, 2010, p. 339.

Fig. 104a/b: Mesolábio.

Fig. 105a/b: Creese, 2010, p. 352-3.

\section{Capítulo 7}

Fig. 106: Coleção Museu Lavigerie de Cartago. Perrot, 1971, plate xii. Fig. 107: Coleção Museu Aquincum, Hungria. Perrot, 1971, plate xxii. Fig. 108: Coleção British Museum, London (Maas \& Snyder, 1989, p. 198).

Fig. 109: Lundberg, 1992, p. 213. 